Documentation of Ancestral Caddo Ceramic Vessels and Other Artifacts from East Texas Sites in the George T. Wright Collection at the Sam Noble Oklahoma Museum of Natural History

Timothy K. Perttula

Heritage Research Center, Stephen F. Austin State University

Mark Walters

Heritage Research Center, Stephen F. Austin State University

Bo Nelson

Heritage Research Center, Stephen F. Austin State University

Follow this and additional works at: https://scholarworks.sfasu.edu/ita

Part of the American Material Culture Commons, Archaeological Anthropology Commons, Environmental Studies Commons, Other American Studies Commons, Other Arts and Humanities Commons, Other History of Art, Architecture, and Archaeology Commons, and the United States History Commons

Tell us how this article helped you.

This Article is brought to you for free and open access by the Center for Regional Heritage Research at SFA ScholarWorks. It has been accepted for inclusion in Index of Texas Archaeology: Open Access Gray Literature from the Lone Star State by an authorized editor of SFA ScholarWorks. For more information, please contact cdsscholarworks@sfasu.edu. 
Documentation of Ancestral Caddo Ceramic Vessels and Other Artifacts from East Texas Sites in the George T. Wright Collection at the Sam Noble Oklahoma Museum of Natural History

Creative Commons License

(c) (1) (9)

This work is licensed under a Creative Commons Attribution-NonCommercial 4.0 International License 


\section{Documentation of Ancestral Caddo Ceramic Vessels and Other Artifacts from East Texas Sites in the George T. Wright Collection at the Sam Noble Oklahoma Museum of Natural History}

Timothy K. Perttula, Mark Walters, and Bo Nelson with contributions by Matthew C. Pailes

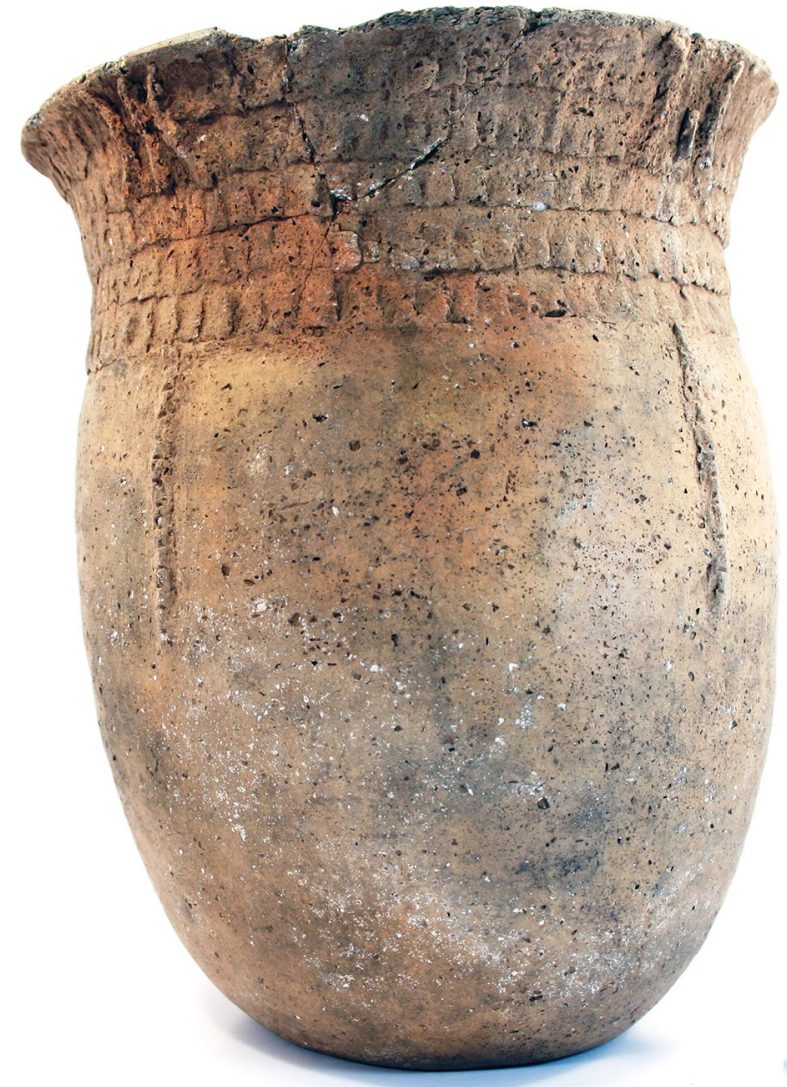

Special Publication No. 49

Friends of Northeast Texas Archaeology, Austin and Pittsburg 


\section{Editor, Timothy K. Perttula 10101 Woodhaven Dr. Austin, Texas 78753 tkp4747@aol.com}

Distribution, Bo Nelson, 344 CR 4154

Pittsburg, Texas 75686

RBoNelson@aol.com

Cover art:

Nash Neck Banded jar

Copyright (C) 2018, Friends of Northeast Texas Archaeology

Pittsburg and Austin 


\section{Table of Contents}

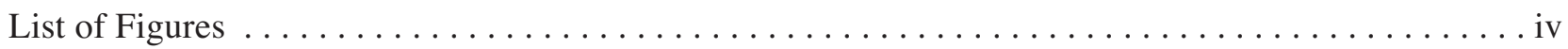

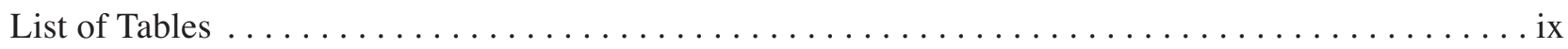

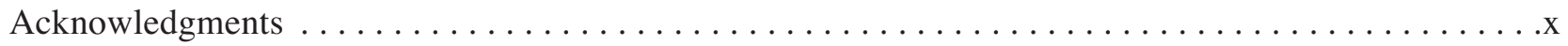

Introduction to the George T. Wright Collection $\ldots \ldots \ldots \ldots \ldots \ldots \ldots \ldots \ldots \ldots \ldots \ldots \ldots \ldots \ldots$

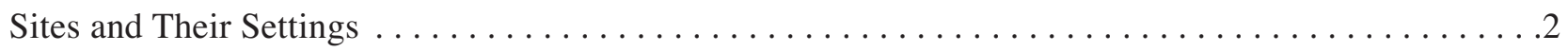

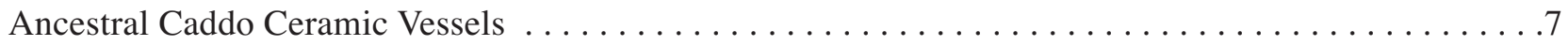

Miscellaneous Ceramic Artifacts . . . . . . . . . . . . . . . . . . . . . . . 94

Summary of the George T. Wright Collection Vessel Assemblage from East Texas Sites . . . . . . .94

Comparisons to other nearby Red River County, Texas, Vessel Assemblages . . . . . . . . . . . 98

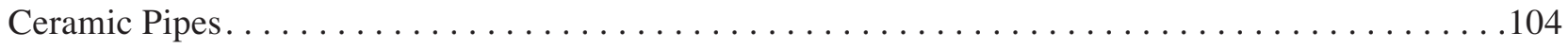

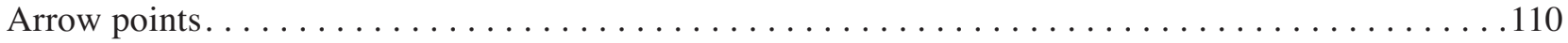

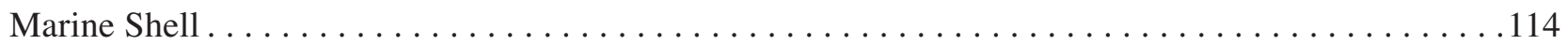

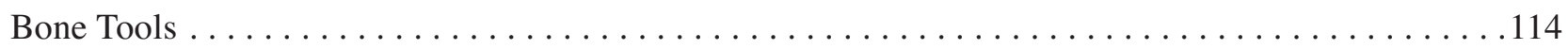

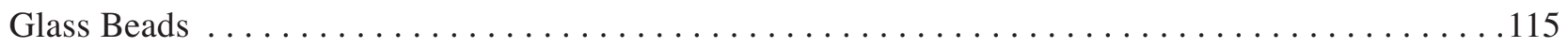

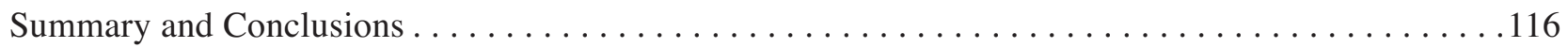

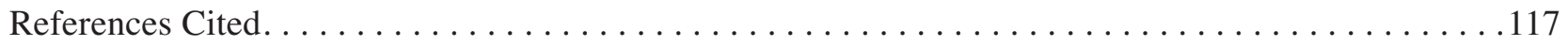

Appendix I, Observations on the Pueblo Ceramic Vessel found in Lamar County, Texas

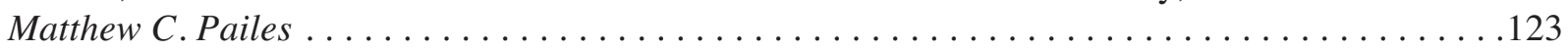




\section{List of Figures}

Figure 1. The location of the Wright Plantation and Sam Kaufman sites in Red River County, Texas. . . . ..1

Figure 2. Map of the Wright Plantation site (41RR7) in Red River County, Texas. ................ 3

Figure 3. Plan map of the eastern part of the Sam Kaufman site (after Perttula 2008:Figure 5; see also

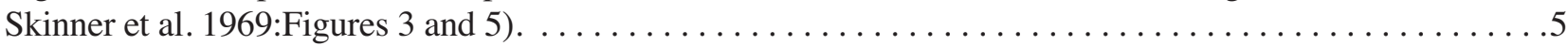

Figure 4. Features and block excavations on the East Mound (after Perttula 2008:Figure 6) . . . . . . . .6

Figure 5. Hudson Engraved bottle (GTW-97): a, body and pedestal base; b, restored neck opening and vessel body . . . . . . . . . . . . . . . .

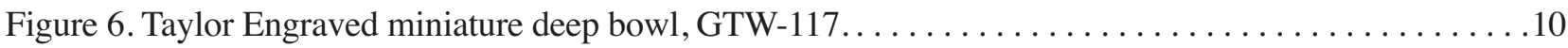

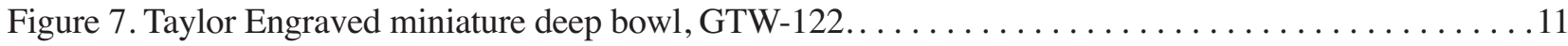

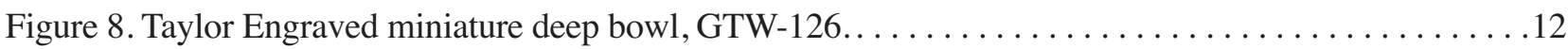

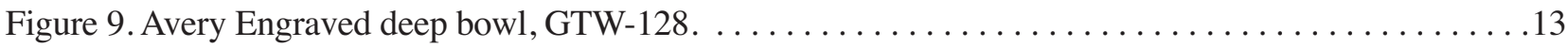

Figure 10. Decorative elements on Avery Engraved, var. Graves deep bowl, GTW-134 . . . . . . . . . . 14

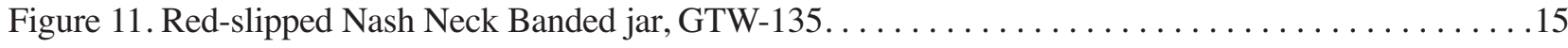

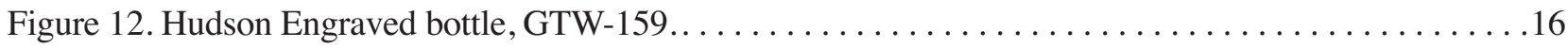

Figure 13. Hudson Engraved bottle with a spool neck, GTW-160 . . . . . . . . . . . . . 17

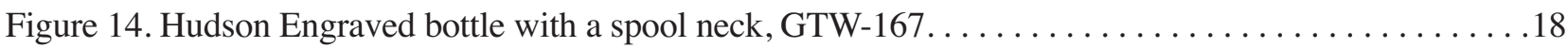

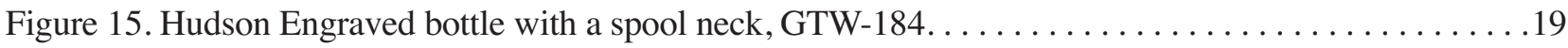

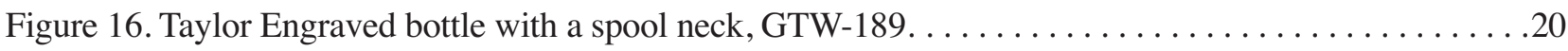

Figure 17. Hudson Engraved bottle with a spool neck, GTW-210...................... 21

Figure 18. cf. Holly Fine Engraved bottle, GTW-224: a, photograph; b, decorative elements on the vessel

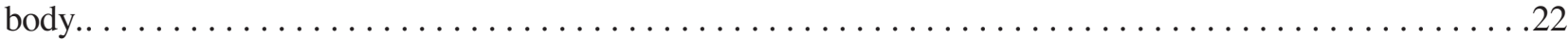

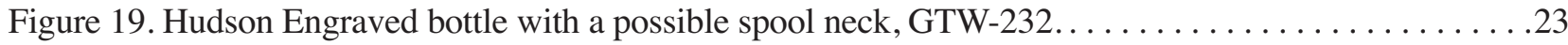

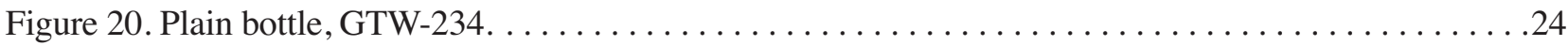

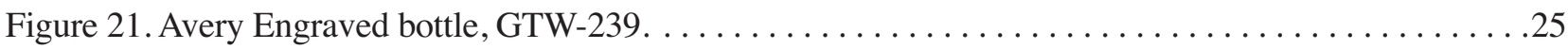

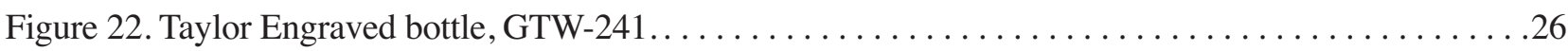

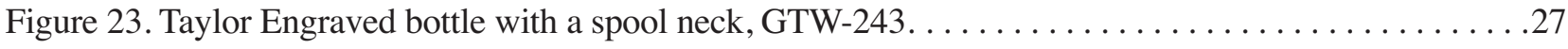




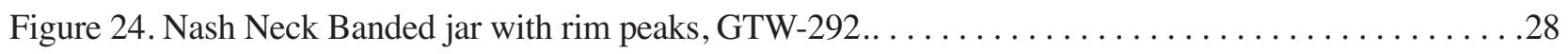

Figure 25. Painted Southwestern jar, GTW-297: a-b, different side views of the vessel. . . . . . . . . . . .29

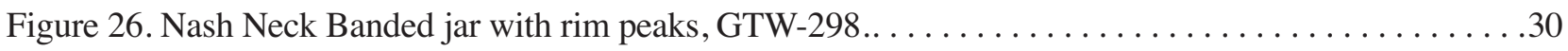

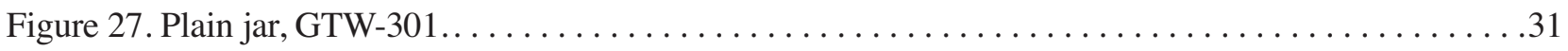

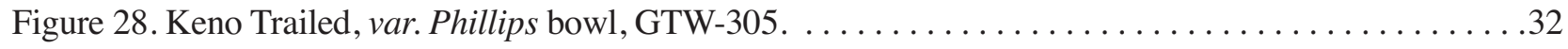

Figure 29. Nash Neck Banded-Avery Engraved jar with strap handles, GTW-307 . . . . . . . . . . . 33

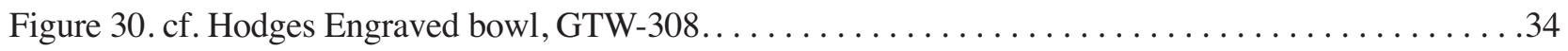

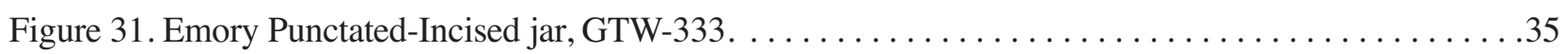

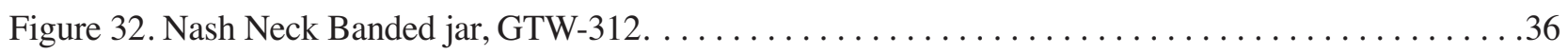

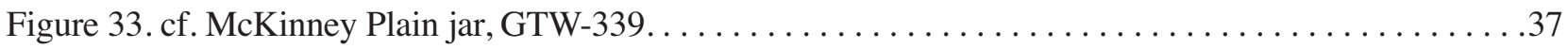

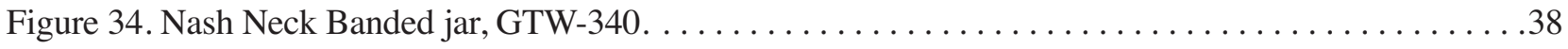

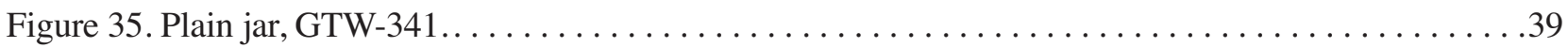

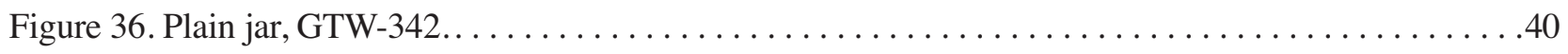

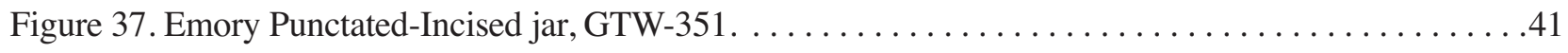

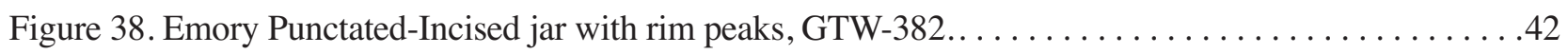

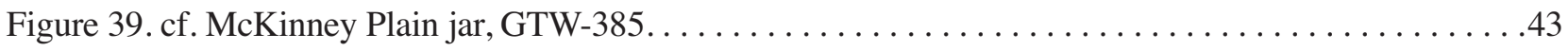

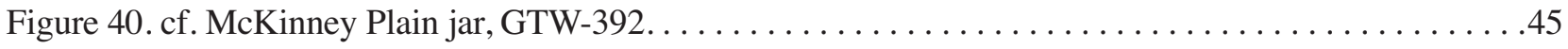

Figure 41. Nash Neck Banded jar, GTW-397. . . . . . . . . . . . . . . . . . . . . . . . .46

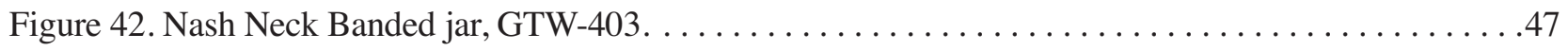

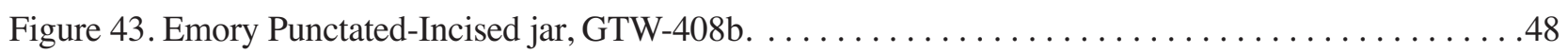

Figure 44. Nash Neck Banded jar, GTW-412. . . . . . . . . . . . . . . . . . . . . . . . . . .49

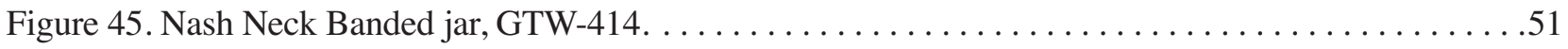

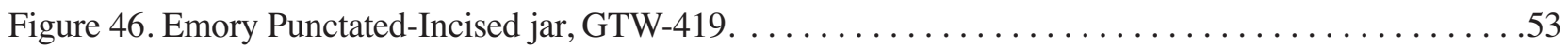

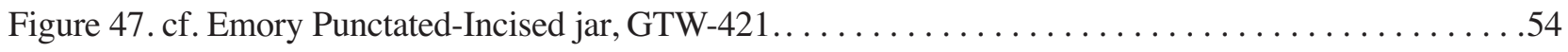

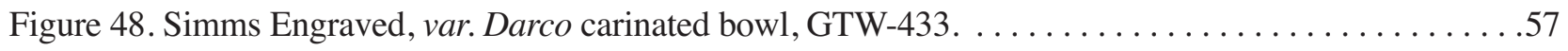




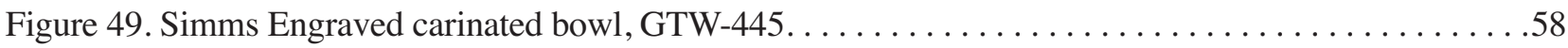

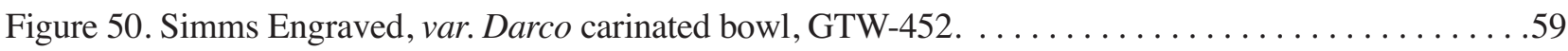

Figure 51. Simms Engraved carinated bowl, GTW-453: a, side view; b, decorative elements. . . . . . . . . 60

Figure 52. Simms Engraved, var. Darco carinated bowl, GTW-455: a, side view; b, decorative elements.. . .61

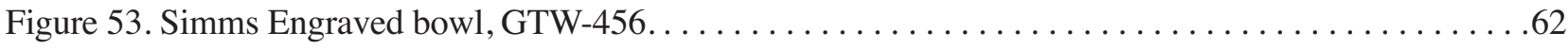

Figure 54. Simms Engraved, var. Darco carinated bowl, GTW-458: a, side view; b, decorative elements.. . .63

Figure 55. Simms Engraved carinated bowl, GTW-459: a, side view; b, decorative elements. . . . . . . . 664

Figure 56. Top-down view of a Simms Engraved, var. Darco carinated bowl, GTW-460.. . . . . . . . 65

Figure 57. Simms Engraved carinated bowl, GTW-461a: a, side view: b, looking down at the rim. . . . 66

Figure 58. Simms Engraved, var. Darco carinated bowl, GTW-461b: a, side view' b, decorative elements.. .67

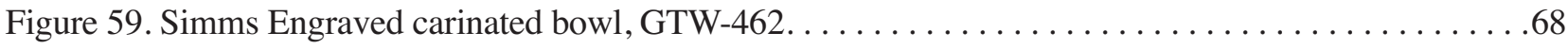

Figure 60. Simms Engraved, var. Darco carinated bowl section: a, side view; b, decorative elements.. . . . .69

Figure 61. Simms Engraved carinated bowl, GTW-468: a, side view; b, decorative elements. . . . . . . . . 70

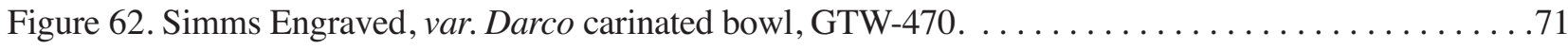

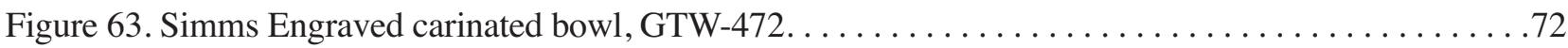

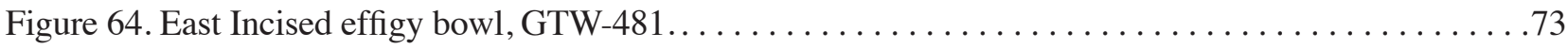

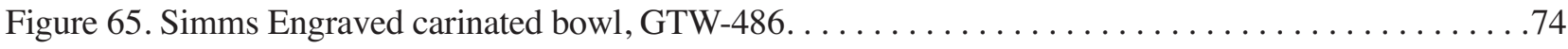

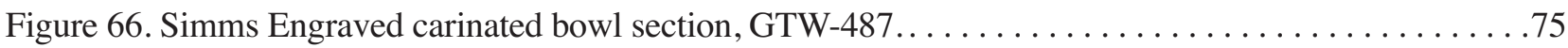

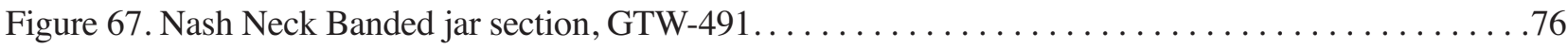

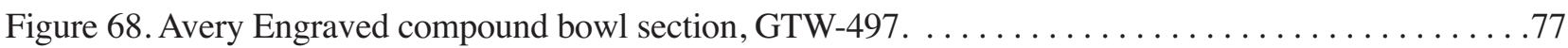

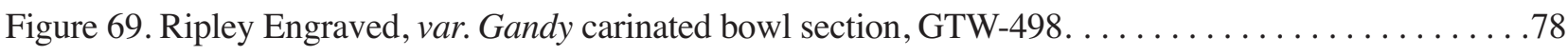

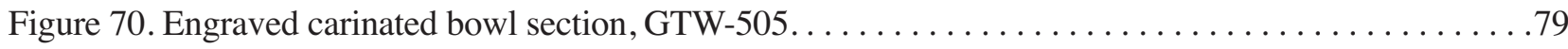

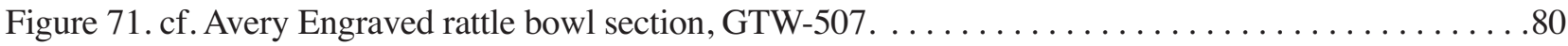

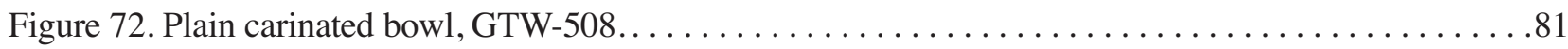

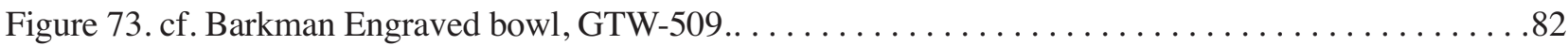




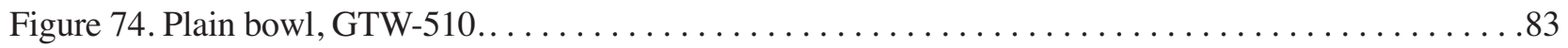

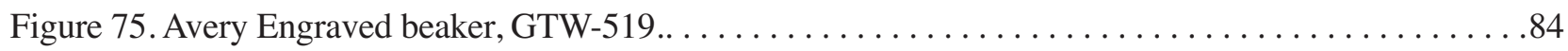

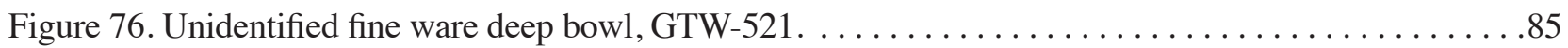

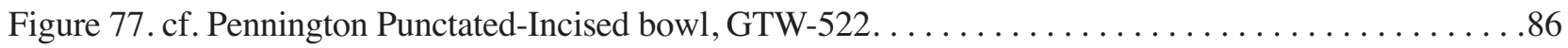

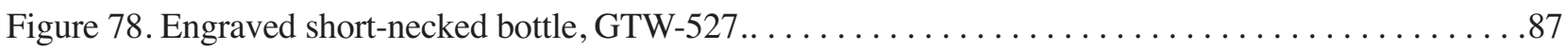

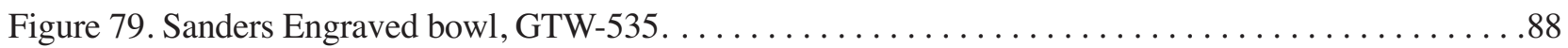

Figure 80. Engraved effigy bowl, GTW-537: a, side view; b, close-up of the bowl; c, bowl and effigy tail. . 89

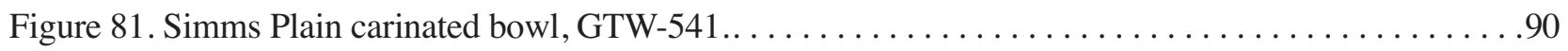

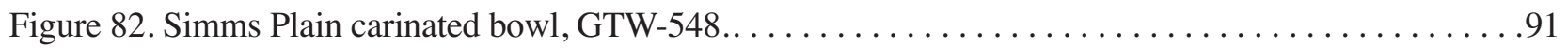

Figure 83. Simms Engraved, var. Darco carinated bowl, GTW-550: a, side view; b, decorative elements.. . .92

Figure 84. Simms Engraved, var. Darco carinated bowl, GTW-553: a, side view; b, decorative elements.. . .93

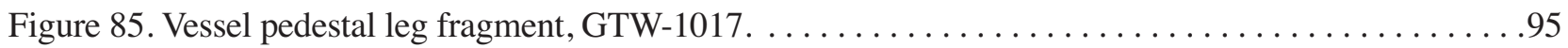

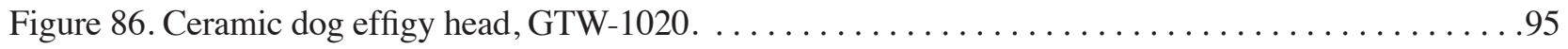

Figure 87. Distribution of Late Caddo period archaeological phases in Arkansas, Louisiana, Oklahoma,

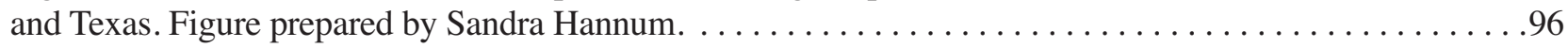

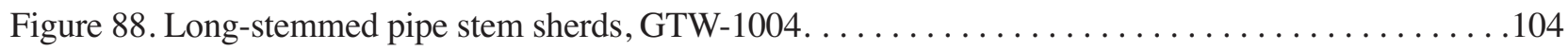

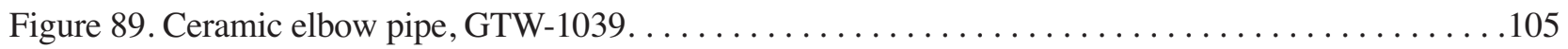

Figure 90. Engraved ceramic elbow pipe, GTW-1038: a, side view; b, decorative elements. . . . . . . . . 106

Figure 91. Engraved elbow pipe stem, GTW-1023: a, engraved lines near the lip; b, cross-hatched

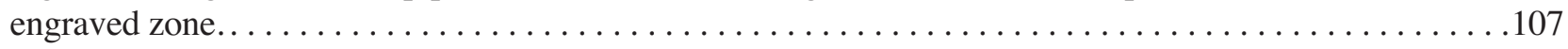

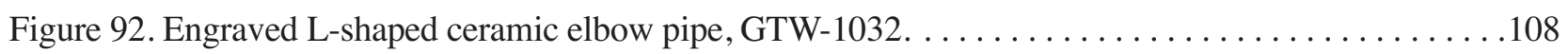

Figure 93. Punctated keeled elbow pipe, GTW-1031: a, raised area with circular punctations; b, elbow pipe bowl and raised area with punctations... . . . . . . . . . . . . . . . . . . . . . 109

Figure 94. Stemmed arrow points in the George T. Wright collection from Red River County, Texas, GTW-994: a-c, f, Alba; d, Hayes; e, g, Catahoula................................. 111

Figure 95. Stemmed arrow points in the George T. Wright collection from Red River County, Texas, GTW-994: c, Homan; a, d-f, Scallorn. . . . . . . . . . . . . . . . . . . . . . . . . . . . 111

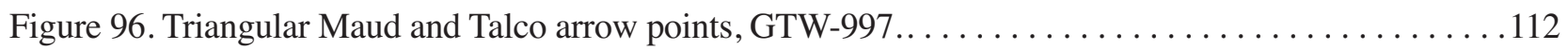




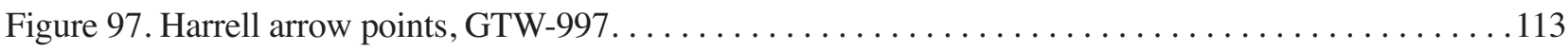

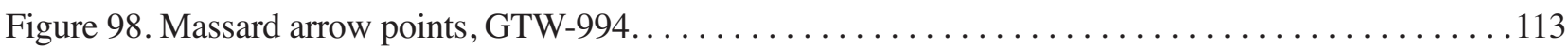

Figure 99. Marine shell columella beads from the Sanders site, GTW-1006. . . . . . . . . . . . . 114

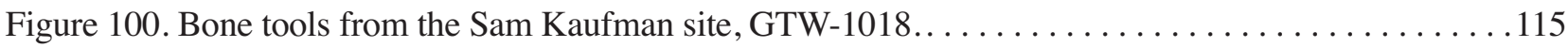

Figure 101. Glass beads from the Wright Plantation site, GTW-1014 . . . . . . . . . . . . . . 115

Figure A1-1. Cross-section of Lamar County vessel, showing aplastics in the paste.. . . . . . . . . 123

Figure A1-2. Close-up of the cross-section of the paste in the Lamar County vessel . . . . . . . . . . . 124

Figure A1-3. Close-up of white and red paints on the Lamar County vessel. . . . . . . . . . . 125 


\section{List of Tables}

Table 1. Shell-tempered McCurtain phase vessels from the Wright Plantation and Sam Kaufman sites in the George T. Wright Collection from Red River County, Texas.. . . . . . . . . . . . . . .97

Table 2. Summary of Early Caddo period Albion phase ceramic vessel assemblages from Red River County, Texas, sites. . . . . . . . . . . . . . . . . . . . . . . . . . . . . . . 99

Table 3. Vessel forms represented in Albion phase assemblages. . . . . . . . . . . . . . . . 100

Table 4. Summary of Middle Caddo period Sanders phase ceramic vessel assemblages from Red River County sites. . . . . . . . . . . . . . . . . . . . . . . . . . . . . . . 100

Table 5. Vessel forms represented in Sanders phase assemblages on the Red River in Red River and

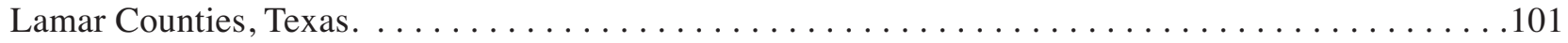

Table 6. Summary of Late Caddo period, McCurtain phase ceramic vessel assemblages from Red River County sites. . . . . . . . . . . . . . . . . . . . . . . . . . . . . . . 102

Table 7. Vessel forms represented in McCurtain phase assemblages in the Red River basin in Red River County, Texas... . . . . . . . . . . . . . . . . . . . . . . . . . . . . . . . . 103

Table 8. Raw materials represented in the arrow points from Red River County, Texas, in the George T. Wright collection... . . . . . . . . . . . . . . . . . . . . . 110 


\section{Acknowledgments}

We thank Dr. Marc Levine and Dr. Susie Fishman-Armstrong of the Sam Noble Oklahoma Museum of Natural History for facilitating access to the George T. Wright Collection from East Texas archaeological sites, and providing work space during our documentation efforts. We are equally grateful for the support provided by the Caddo Nation of Oklahoma for this documentation effort, and we appreciate the visit from Phil Cross (Tribal Historic Preservation Officer and NAGPRA Director) of the Caddo Nation during our work. Thanks to Jesse Todd for taking a look at images of the elbow pipes in the collection, and to Drs. Matt Peeples, Barbara Mills, David Snow, and Matthew C. Pailles for looking at the one Southwestern vessel from a Lamar County site in the collection. Lance Trask prepared a number of figures in this report, except for the Appendix I photographs taken by Matthew C. Pailles, and Bo Nelson took the artifact photographs. Lastly, we thank Dr. Don G. Wyckoff for the Italian dinner he invited us to while we were in Norman, Oklahoma. 


\section{Introduction to the George T. Wright Collection}

From the early 1900s to the mid-1940s George T. Wright was a landowner (Kiomatia Plantation) and Vice-President of the Kiomitia Mercantile Company: General Merchandise in Kiomatia and Paris, Texas. He was also an avid Indian artifact collector at sites along the Red River in Red River County, Texas, as well as in McCurtain County, Oklahoma, especially the collection of Caddo ceramic vessels, and also dug at sites he knew in the area, including the Wright Plantation site (41RR7), which he owned, and the Sam Coffman site (now known as Sam Kaufman, 41RR16, and for a short time known as the Arnold Roitsch site), a few miles downstream along the Red River (Figure 1). Most of these vessels were described as coming from the sandy banks of the Red River.

After George T. Wright died in 1944, his family sold his collections to the University of Oklahoma, where they are now part of the collections held by the Sam Noble Oklahoma Museum of Natural History (SNOMNH). His collection included 722 ceramic vessels, as well as ceramic pipes, arrow points, and various other kinds of artifacts. There is a notebook prepared by Wright in the SNOMNH holdings that we were able to review and glean some information from. It provides his numerical listing of artifacts, a few with specific provenience information-including County as well as B. R. R. (burial, Red River County), S. R. R. (surface, Red River County), B. L. (burial, Lamar County), and B. Titus (burial, Titus County) - as well as simple descriptions of each specific artifact, such as "pot," "red pot," and "bottle."

Our interest in this report is in documenting the George T. Wright Collection of artifacts from East Texas Caddo sites in Red River, Lamar, and Titus counties. The majority of these collections are from burial features at sites in these counties, and almost 90 percent of the vessels are from the Wright Plantation and Sam Kaufman sites.

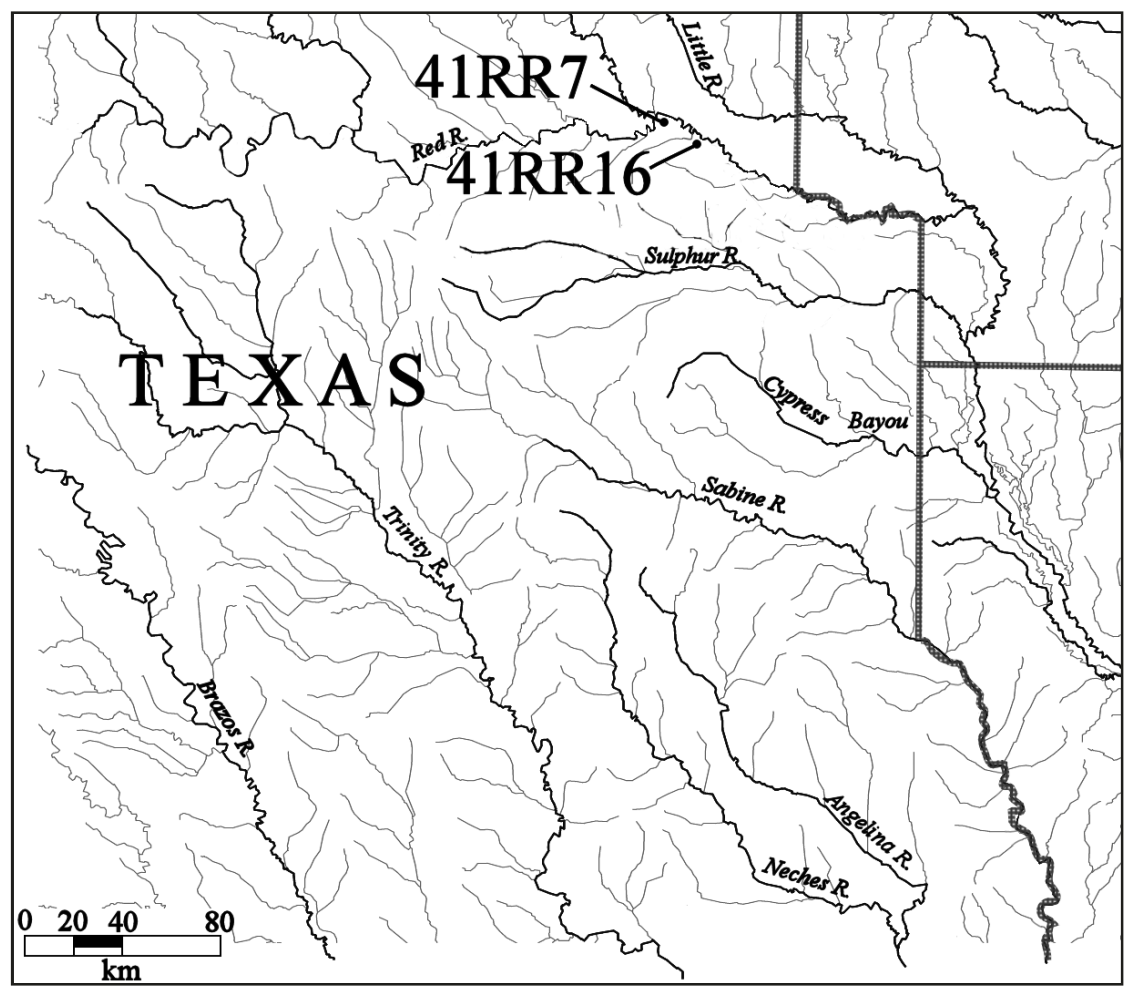

Figure 1. The location of the Wright Plantation and Sam Kaufman sites in Red River County, Texas. 


\section{Sites and Their Settings}

Based on 1940-1941 correspondence between A. T. Jackson and George T. Wright in the files of the Texas Archeological Research Laboratory at The University of Texas at Austin (TARL), the majority of the ceramic vessels in the George T. Wright collection from East Texas sites are from the Wright Plantation (41RR7) and Sam Kaufman (41RR16) sites (Perttula 2017b). In most cases, however, it is not possible to identify each vessel's specific site provenience, though there are hints in the correspondence regarding the ceramic vessels and other artifacts that came from Wright's 1940 excavations at the Sam Kaufman site (Perttula 2017b) as well as information Wright provided in his notebook.

The Wright Plantation site (41RR7) is a multiple mound center on the Red River, about $1 \mathrm{~km}$ north of the Fasken site (41RR14), another multiple mound center (Prikryl 2008). The site is $7 \mathrm{~km}$ upstream from the Sam Kaufman site (41RR16) (see Figure 1), a very large village with two constructed mounds and several discrete cemeteries (Perttula 2008).

The Wright Plantation site has both Middle Caddo period Mound Prairie phase (ca. A.D. 1100-1300 or A.D. 1200-1400) and Late Caddo period McCurtain phase (ca. A.D. 1300-1700, or ca. A.D. 1400-1700) occupations at the site (the chronologies of the Caddo periods in this area have not been codified because not enough radiocarbon dates have been obtained from Caddo sites), and at least one of the mounds (B) at Wright Plantation (Figure 2) appears to have been constructed and used as a burial mound during the McCurtain phase; R. King Harris referred to this mound as a "low sandy mound." Mound A is a large platform mound, ca. 30 x 15 x 5 m in length, width, and height. Mound B is ca. 15 x 8 x $0.6 \mathrm{~m}$ in length, width, and height, and had been reduced in size by plowing. According to records on file at TARL, the Wright Plantation site had two other large mounds but they had eroded into the Red River before any investigations were conducted. During the early 1930s, the landowner, George Wright, recovered 24 ceramic vessels from this mound, sent them in 1935 to The University of Texas for restoration, and then apparently donated these vessels to the University of Oklahoma shortly thereafter. This collection is now in the holdings of the University of Oklahoma's Sam Noble Oklahoma Museum of Natural History.

In about 1949, another 12 ancestral Caddo ceramic vessels were recovered in Mound A during the digging of a well just north of the 1818 plantation house that sits on the mound (see Figure 2). The location of this collection of vessels from the Wright Plantation site is not known.

The collections from TARL have three ancestral Caddo ceramic vessels from the Wright Plantation site on the George Wright Farm (Perttula 2017a); their specific provenience is not known. They were donated in the 1930s to the University of Texas by W. A. Rikard, a local avocational archaeologist. They include a portion of a shell-tempered jar, a grog-tempered Wilder Engraved bottle that was likely obtained in trade or exchange from a Titus phase group living in the Big Cypress or Sabine River basins 50+ miles south of the Red River (see Perttula 2012), and a Crockett Curvilinear Incised olla or short-necked bottle. The first two vessels were recovered by Rikard from a shallow (ca. $28 \mathrm{~cm}$ bs) Late Caddo McCurtain phase burial where the head of the deceased was to the east, and faced west, and two vessels had been placed by the feet and two others by the head (TARL files).

TARL files indicate that a Joseph K. Long III excavated a Hudson Engraved bottle from the plow zone of Mound B. Lloyd Harper had collected a turquoise pendant from the surface of Mound B.

The ceramic sherds in the TARL collections from the Wright Plantation site were primarily donated in 1930 by George T. Wright, and likely came from a surface collection when the site was plowed. One distinctive engraved sherd was donated to the University of Texas in March 1942. 


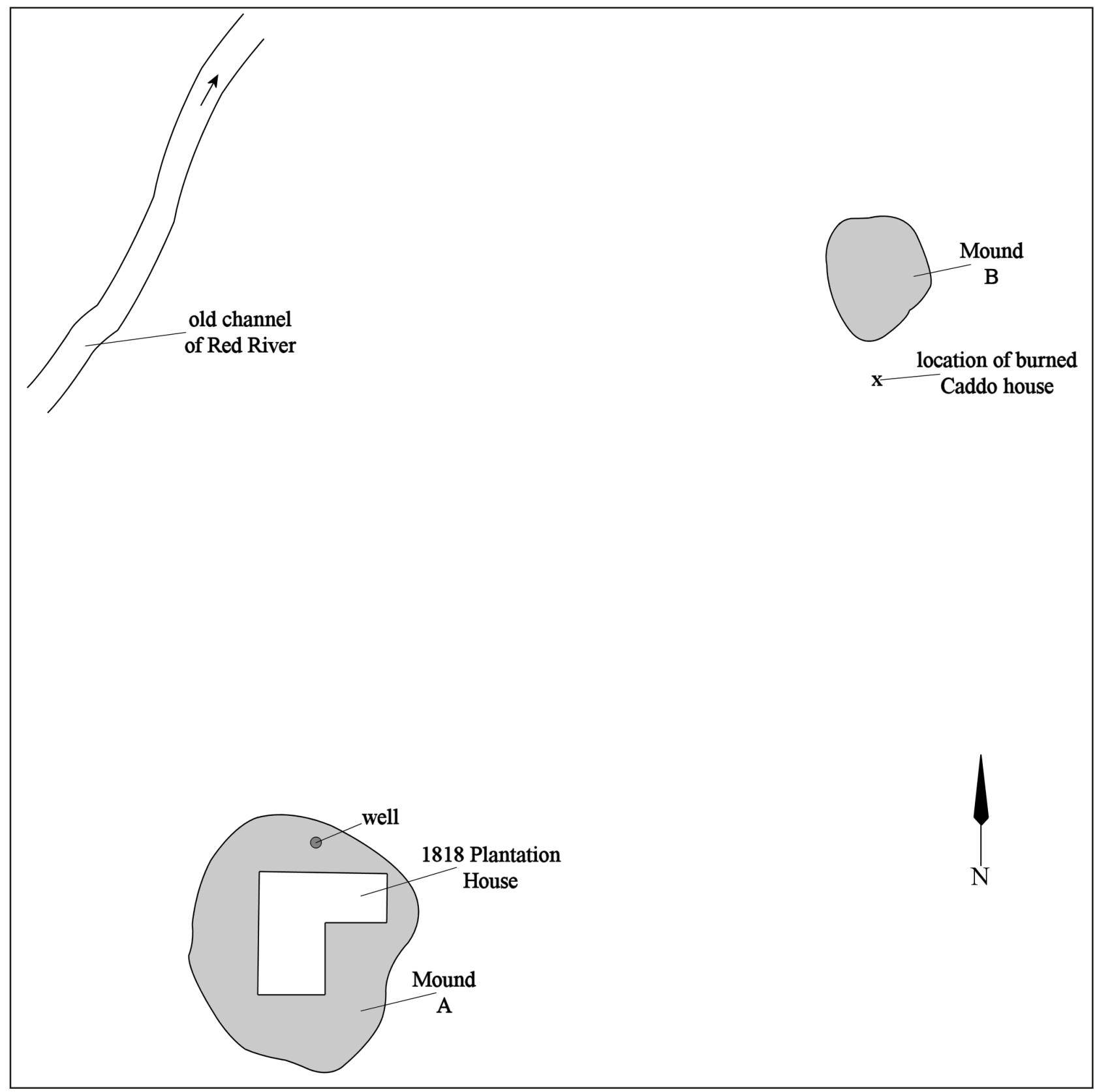

Figure 2. Map of the Wright Plantation site (41RR7) in Red River County, Texas.

The 61 sherds in the collection from the site are from plain ware, utility ware, and fine ware vessels tempered with either shell, grog, grog-hematite, and bone (Perttula 2017a:Table 1). About 65.6 percent of the sherds (and 61.9 percent of the decorated sherds) are from vessels tempered with crushed and burned mussel shell; these are from vessels made by Late Caddo period McCurtain phase (ca. A.D. 1400-1700) potters. The remainder of the sherds are likely from a ca. A.D. 1000-1200 Early Caddo period component that is represented by at least the previously mentioned Crockett Curvilinear Incised vessel, and by sherds from primarily grog-tempered vessels.

There are also collections from the Wright Plantation site at the National Museum of Natural History (NMNH) at the Smithsonian Institution (Dorothy Lippert, May 2017 personal communication). The R. King 
Harris Collection from the site includes ca. 15 ceramic vessel sherds and three arrow points from the Late Caddo period component, along with a large shell-tempered and red-slipped Avery Engraved compound bowl (Perttula 2016a:Figure 2). Such vessels are present in McCurtain phase contexts in this stretch of the Red River (see Perttula 2008:Figure 57c-d), most likely from post-A.D. 1500 contexts. Site records on the Texas Historic Sites Atlas indicate that a Hudson Engraved vessel, also dating to late McCurtain phase times, came from the "low sandy mound" along with a turquoise pendant.

The historic Caddo component at the Wright Plantation site is represented by two gunflints, ca. 15 glass beads (plus another 18 glass beads to be discussed below in the Wright Collection), two brass tinklers, two metal buttons, an iron gun main spring, and a brass gun ramrod guide. A second collection from the site was obtained by Joseph Long, and donated to the NMNH in 2002. This collection has projectile points $(n=4)$, one perforator, scrapers $(n=3)$, and flakes $(n=3)$, plus daub $(n=2)$ and ceramic vessel sherds: decorated grog or shell-tempered rims $(n=33)$, red-slipped sherds $(n=33)$, and 259 plain grog- or shell-tempered body sherds.

George T. Wright donated one vessel to the University of Texas from the Sam Kaufman site. Correspondence in the TARL files (Perttula 2017b) indicates that he did conduct excavations in 1940 in the northeastern quadrant of the East Mound at the Sam Kaufman site (Figure 3), where a number of ancestral burial features were excavated. The Sam Kaufman site is a large ancestral Caddo village and mound center, with extensive cemeteries that began to be exposed along the eroding bank of the Red in the 1940s and 1950s. The burials are from upper and lower cemeteries of post-A.D. 1500 McCurtain phase and ca. A.D. 1700 Historic Caddo age that are both north and east of the principal mound (or East Mound) at the site (see Perttula 2008; Skinner et al. 1969). The more recent work conducted in the late 1960s and early 1990s in the East Mound uncovered a burned and buried rectangular Caddo specialized structure, a shaft tomb with eight individuals, and other burial and non-burial features (Figure 4).

The one vessel in the TARL collections from the Sam Kaufman site is a Simms Engraved, var. Darco carinated bowl; this vessel was donated by George T. Wright. This type has notched lips and discontinuous engraved elements with downward-pointing tick marks (Perttula and Selden 2014:Figure 37a-b). Most have four repeating sets of curvilinear to semi-circular ticked engraved lines. Other early historic Caddo sites in East Texas with var. Darco vessels include the Hatchel (41BW3) and Clements (41CS25) sites on the Red River and Black Bayou, respectively, and several Kinsloe phase (or Nadaco Caddo) sites in the mid-Sabine River basin in East Texas (see Jones 1968). During Wright's excavations in the East Mound he recovered an iron knife blade fragment from one burial feature (TARL files; see also Perttula 2017b).

The T. M. Sanders site (41LR2) is one of the more important ancestral Caddo sites known in East Texas, primarily because of its two earthen mounds and the well-preserved mortuary features of Caddo elite persons buried in Mound No. 1 (the East Mound). The Sanders site is located on a broad alluvial terrace just south of the confluence of Bois d'Arc Creek and the Red River. A large number of ceramic vessels are from burial features excavated by University of Texas archaeologists in Mound No. 1 (East Mound) in July and August 1931 (Jackson et al. 2000); others are from excavations in midden deposits between the two mounds (see Krieger 1946:Figure 9). One vessel in the George T. Wright collection at SNOMNH is from a near-mound burial feature at the Sanders site, probably in the midden deposits between the mounds. 


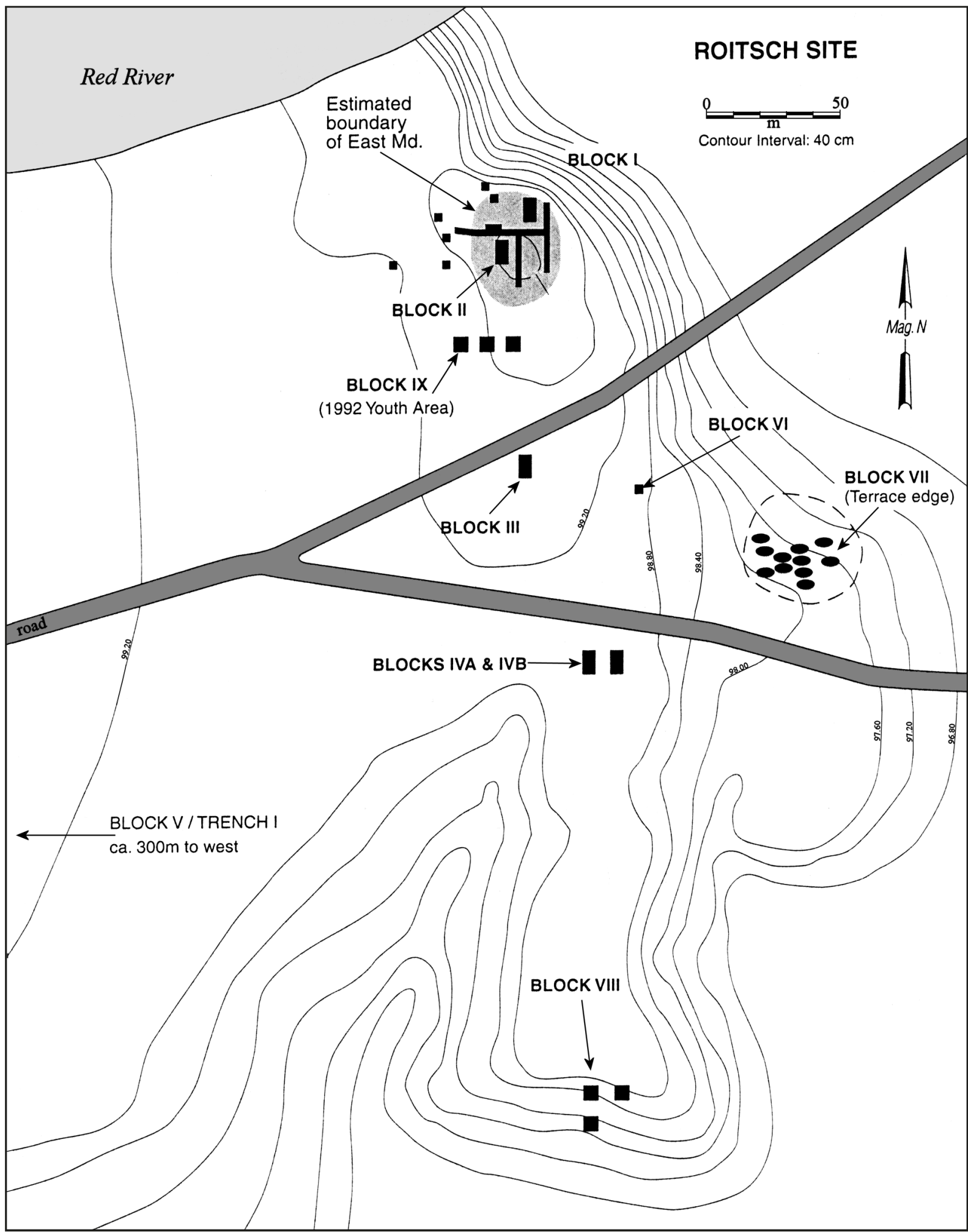

Figure 3. Plan map of the eastern part of the Sam Kaufman site (after Perttula 2008:Figure 5; see also Skinner et al. 1969:Figures 3 and 5). 


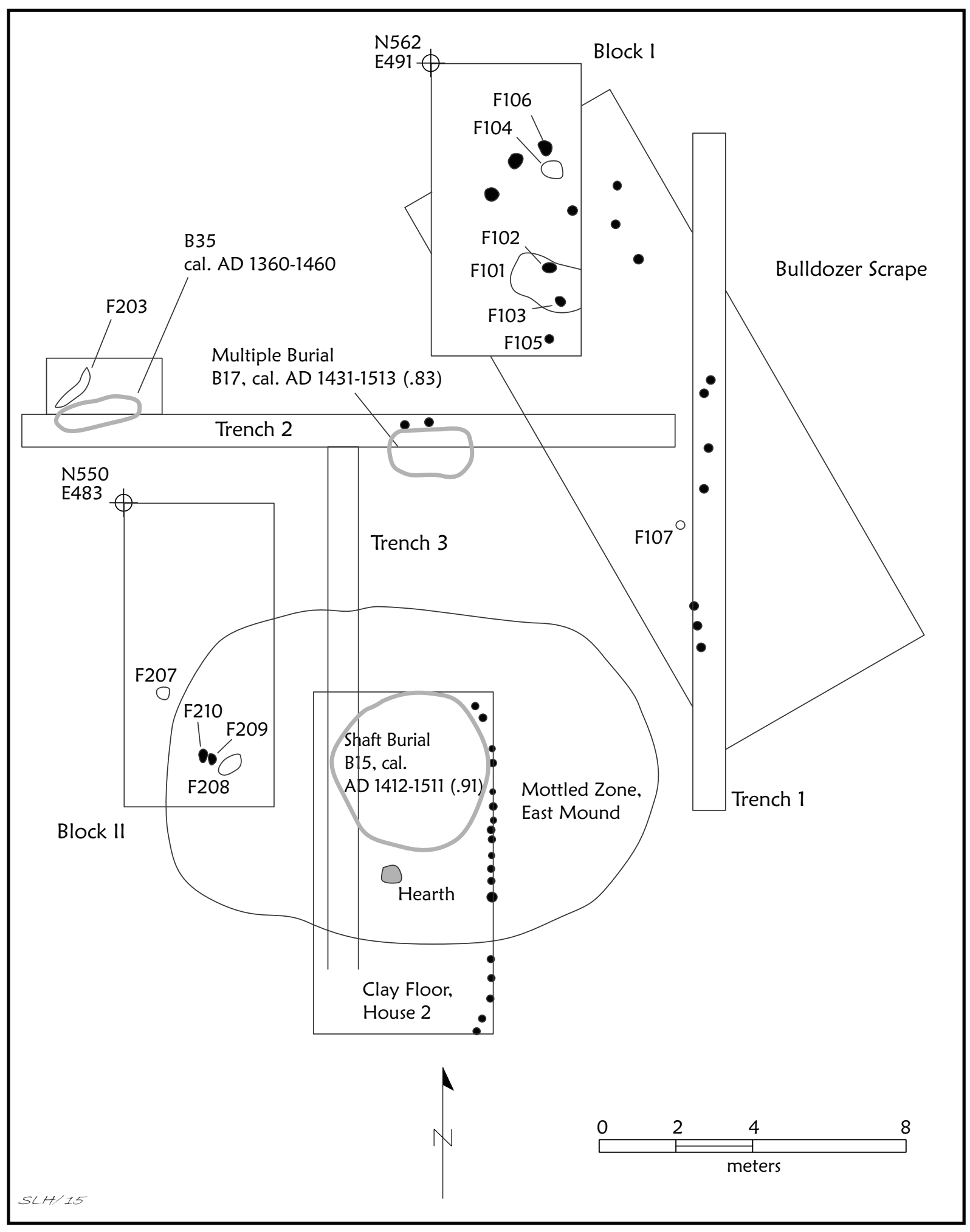

Figure 4. Features and block excavations on the East Mound (after Perttula 2008:Figure 6). 


\section{Ancestral Caddo Ceramic Vessels}

There are 85 ancestral Caddo ceramic vessels and vessel sections in the George T. Wright collection from East Texas sites at the Sam Noble Oklahoma Museum of Natural History (SNOMNH); each vessel or vessel section is described in this section. The vessels and vessel sections are from sites in Red River (96.4 percent), Lamar (2.4 percent), and Titus (1.2 percent) counties, virtually all from the excavation of burial features. Three of the Red River County vessels (3.6 percent) were designated by Wright as S. R. R., meaning they were found on the surface of a Caddo site. We take that to mean that these were found on the surface of disturbed burial features, likely exposed during plowing activities or from cut bank erosion.

As with other ancestral Caddo ceramic vessel documentation studies completed of ceramic assemblages from East Texas sites (cf. Perttula et al. 2013, 2015), the following consistent set of attributes were employed in the study and documentation of the ceramic vessels from the George T. Wright Collection at the SNOMNH:

Non-plastics: Deliberate and indeterminate materials in the paste (Rice 1987:411), including a variety of tempers (i.e., grog or crushed sherds, bone, hematite, and shell, as well as combinations of different temper inclusions) and "particulate matter of some size." The grog, bone, hematite, or shell appears to have been deliberately added to the paste as tempers. The bone or shell used for temper had been burned and calcined, then crushed, before it was added to the paste.

Vessel Form: Vessel form categories include open containers (bowls of several sizes, including effigy bowls, carinated bowls, and compound bowls) and restricted containers, including jars and bottles, as well as plates. As restricted containers, jars allow access by hand, but bottles do not (Brown 1996:335). Other form attributes that were recorded include the rim profile (outflaring or everted, vertical or standing, and inverted), lip profile (rolled to the exterior, rounded, flat, or thinned), and base shape (flat or rounded).

Core Colors: Observations on ceramic cross-section colors permit consideration of oxidation patterns (Teltser 1993:Figure 2A-H; Perttula 2005:Figure 5-30), and thus the conditions under which the vessel was fired and then cooled after firing. Comments are included for these attributes on the presence and location of fire-clouding, sooting, or smudging from cooking use (Skibo 1992), and the preservation of any charred organic remains.

Wall Thickness: Thickness was recorded in millimeters, using a vernier caliper, at the lip, along the rim, at several points along the body when possible, and at the base when possible (only for the vessels that were not complete).

Interior and Exterior Surface Treatment: The primary methods of finishing the surface of the vessels includes either smoothing, burnishing, and rarely polishing (Rice 1987:138). Brushing, while a popular method of roughening the surface (particularly the body) of large and small Middle (ca. A.D. 1200-1450) and Late Caddo (ca. A.D. 1450-1680) period cooking jars in several parts of the Caddo area (Perttula 2015a), is here considered a decorative treatment rather than solely a functional surface treatment (cf. Rice 1987:138), although not all Caddo ceramic analysts treat brushing as a decorative treatment. Smoothing creates "a finer and more regular surface... [and] has a matte rather than a lustrous finish" (Rice 1987:138). Burnishing, on the other hand, creates an irregular lustrous finish marked by parallel facets 
left by the burnishing tool (perhaps a pebble or bone). A polished surface treatment is marked by a uniform and highly lustrous surface finish, done when the vessel is dry, but without "the pronounced parallel facets produced by burnishing leather-hard clay" (Rice 1987:138).

The application of a hematite-rich clay slip (Ferring and Perttula 1987), either red or black after firing in an oxidizing or reducing (i.e., low-oxygen) environment, respectively, is another form of surface treatment noted in many East Texas assemblage, and the frequency of red-slipped vessels is a notable characteristic of the George T. Wright vessel assemblages. On these vessels, the clay slip is more frequently applied on the vessel exterior, or on both surfaces, than on the interior surface, and then was burnished after it was leather-hard or dry.

Height and Orifice Diameter: These attributes, measured in centimeters, were recorded with a ruler.

Diameter at Bottom of Rim and Base Diameter: Also recorded in millimeters using a ruler, these attributes permit characterization of the overall contour and shape of the vessel.

Volume: With measurements of height and orifice diameter obtained from the vessels, as well as other measurements of size (i.e., base diameter and maximum body width), volumes were estimated by comparison with known vessel volumes of specific forms (i.e., carinated bowl, jar, bottle, compound bowl, and bowl) in many other recently documented Caddo vessel assemblages.

Base Diameter and Shape: these attributes were either measured in centimeters or by shape attributes: circular or square, and flat, rounded (convex), or concave.

Decoration: Decorative techniques present in the vessel collection include engraving, incising, trailing, punctating, pinching, brushing, and appliquéing, and on certain vessels, combinations of decorative techniques (i.e., incised-punctated) created the decorative elements and motifs. Engraving was done with a sharp tool when the vessel was either leather-hard, or after it was fired, as were the tick marks often seen on vessels in this collection, while the other decorative techniques were executed with tools (trailing, incising, and punctation), by adding strips of clay to the wet body (appliqué), using frayed sticks or grass stems (brushing) dragged across the body surface, or fingernails (certain forms of punctations and pinching), when the vessel was wet or still plastic. Excising is considered a form of engraved decoration, where the clay is deliberately and closely marked/scraped and carved away with a sharp tool, usually to create triangular elements, tick marks, or excised punctations.

Use of Pigments: Another form of vessel decoration is the use of red (hematite or ochre) or white (kaolin clay) clay pigments that have been smeared or rubbed into the engraved lines of certain vessels.

Type: The kinds of ceramic types and defined varieties in the George T. Wright collections follow Suhm and Jelks (1962), Schambach and Miller (1984), Fields et al. (2014), and for any post-1962 ceramic types: Perttula and Selden (2014).

There are 85 ancestral Caddo ceramic vessels in the George T. Wright collection from sites in Red River and Lamar counties, Texas. They include bottles, deep bowls, bowls, carinated bowls, compound bowls, and jars. 
SITE NAME OR SITE NUMBER: George T. Wright Collection, Red River County, Texas

VESSEL NO.: GTW-97 [TX068/1], B. R. R. (Burial, Red River County)

VESSEL FORM: Bottle with a $4.9 \mathrm{~mm}$ high pedestal base (Figure 5a)

NON-PLASTICS AND PASTE: shell

RIM AND LIP FORM: N/A

CORE COLOR: B (fired and cooled in a reducing or low oxygen environment)

INTERIOR SURFACE COLOR: black

EXTERIOR SURFACE COLOR: black

WALL THICKNESS (IN MM): body, $7.6 \mathrm{~mm}$

INTERIOR SURFACE TREATMENT: none

EXTERIOR SURFACE TREATMENT: smoothed

HEIGHT (IN CM): 14.6+ [neck is missing]

ORIFICE DIAMETER (IN CM): N/A

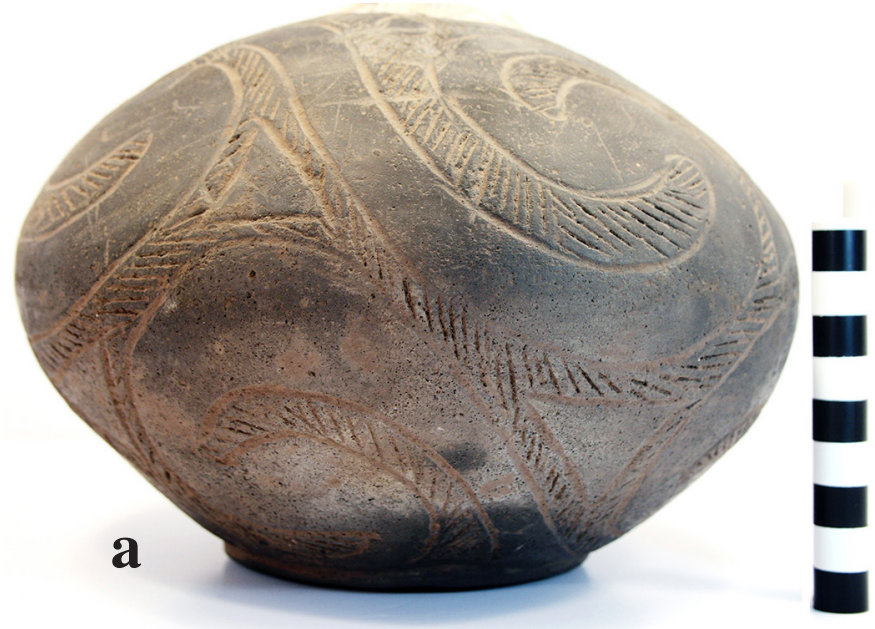

DIAMETER AT BOTTOM OF RIM OR NECK

(IN CM): 3.1 ; maximum body diameter: $19.2 \mathrm{~cm}$

BASE DIAMETER (IN CM) AND SHAPE OF BASE: $9.5 \mathrm{~cm}$, circular

\section{ESTIMATED VOLUME (IN LITERS): N/A}

DECORATION (INCLUDING MOTIF AND ELEMENTS WHEN APPARENT): The vessel body has four sets of curvilinear engraved scroll elements filled with incised lines pitched in different directions. Each set of curvilinear scrolls has a single inner engraved triangle element surrounded by incised lines. At the base of the neck scrolls meet to form a board rectangular engraved zone with four negative ovals (Figure $5 b$ )

\section{PIGMENT USE AND LOCATION ON} VESSEL: none

TYPE AND VARIETY (IF KNOWN): Hudson Engraved (Suhm and Jelks 1962:81 and Plate 41)

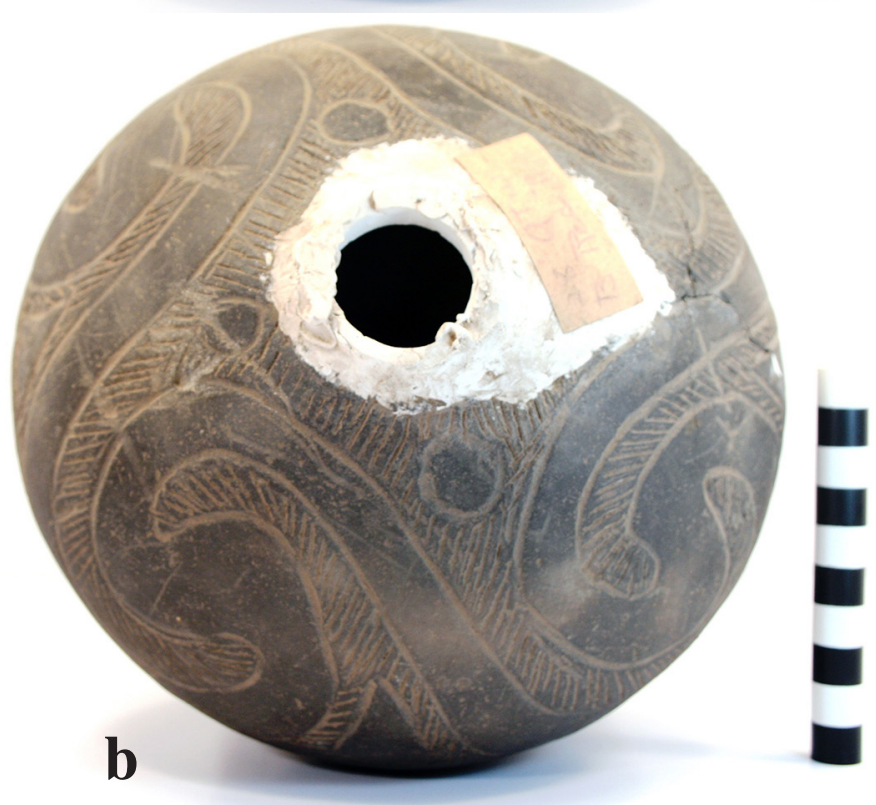

Figure 5. Hudson Engraved bottle (GTW-97): a, body and pedestal base; $b$, restored neck opening and vessel body. 
SITE NAME OR SITE NUMBER: George T. Wright Collection, Red River County, Texas

VESSEL NO.: GTW-117 \{TX 069/1], B. R. R.

VESSEL FORM: Miniature deep bowl (Figure 6)

NON-PLASTICS AND PASTE: shell

RIM AND LIP FORM: Everted rim and rounded, exterior folded lip

CORE COLOR: F (fired in a reducing environment and cooled in the open air)

INTERIOR SURFACE COLOR: red

EXTERIOR SURFACE COLOR: red

WALL THICKNESS (IN MM): rim, 4.5 mm

INTERIOR SURFACE TREATMENT: burnished

EXTERIOR SURFACE TREATMENT: burnished

HEIGHT (IN CM): 5.4

ORIFICE DIAMETER (IN CM): 8.1

DIAMETER AT BOTTOM OF RIM OR NECK (IN CM): 6.1

BASE DIAMETER (IN CM) AND SHAPE OF BASE: $3.2 \mathrm{~cm}$, circular and flat

ESTIMATED VOLUME (IN LITERS): 0.35

DECORATION (INCLUDING MOTIF AND

ELEMENTS WHEN APPARENT): The vessel rim has a continuous negative curvilinear scroll motif with associated negative circle elements at the end of the scrolls that are defined by excised areas. The vessel has an interior and exterior red-slipped surface (Figure 6).

PIGMENT USE AND LOCATION ON VESSEL: none

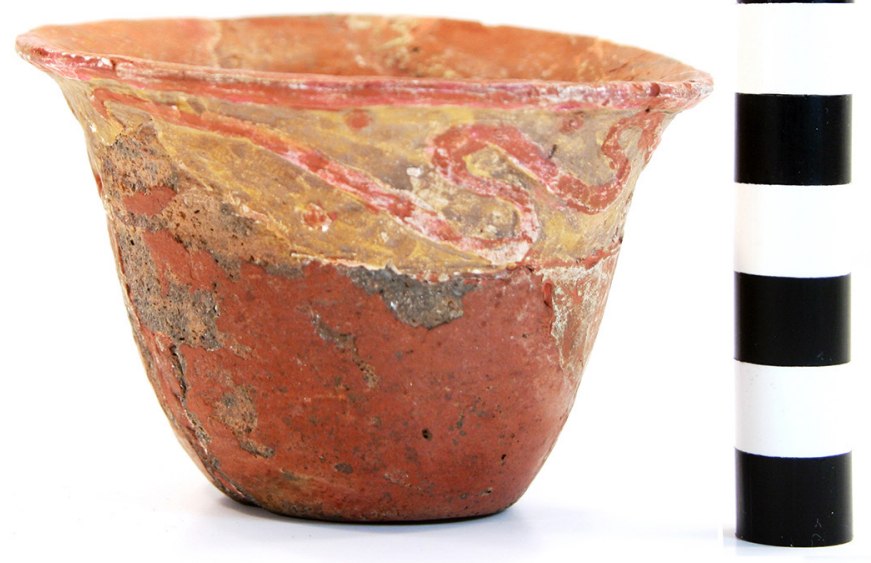

Figure 6. Taylor Engraved miniature deep bowl, GTW-117.

TYPE AND VARIETY (IF KNOWN): Taylor Engraved (Suhm and Jelks 1962:149-152) 
SITE NAME OR SITE NUMBER: George T. Wright Collection, Red River County, Texas

VESSEL NO.: GTW-122 [TX 070/1], B. R. R.

VESSEL FORM: Miniature deep bowl (Figure 7)

NON-PLASTICS AND PASTE: shell

RIM AND LIP FORM: Everted rim and rounded lip

CORE COLOR: F (fired in a reducing environment and cooled in the open air)

INTERIOR SURFACE COLOR: red

EXTERIOR SURFACE COLOR: red

WALL THICKNESS (IN MM): rim, $5.6 \mathrm{~mm}$

INTERIOR SURFACE TREATMENT: burnished

EXTERIOR SURFACE TREATMENT: burnished

HEIGHT (IN CM): 6.5

ORIFICE DIAMETER (IN CM): 10.2

DIAMETER AT BOTTOM OF RIM OR NECK

(IN CM): 7.8

BASE DIAMETER (IN CM) AND SHAPE OF

BASE: $5.2 \mathrm{~cm}$, circular and flat

ESTIMATED VOLUME (IN LITERS): 0.5

DECORATION (INCLUDING MOTIF AND ELEMENTS WHEN APPARENT): The rim has a continuous negative curvilinear scroll motif repeated six times around the vessel; the negative scrolls are created by excising selected areas of the red-slipped surface. To either side of the negative scrolls are six small negative circle elements (Figure 7).

PIGMENT USE AND LOCATION ON VESSEL:

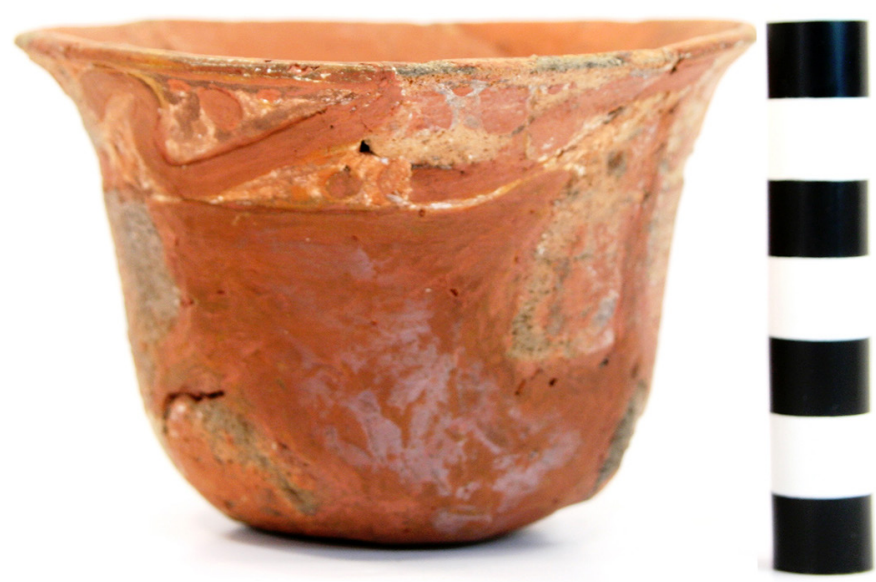

Figure 7. Taylor Engraved miniature deep bowl, GTW-122. none

TYPE AND VARIETY (IF KNOWN): Taylor Engraved 
SITE NAME OR SITE NUMBER: George T. Wright Collection, Red River County, Texas

VESSEL NO.: GTW-126 [TX 071/1], B. R. R.

VESSEL FORM: Miniature deep bowl (Figure 8)

NON-PLASTICS AND PASTE: shell

RIM AND LIP FORM: Everted rim and rounded, exterior folded lip

CORE COLOR: F (fired in a reducing environment and cooled in the open air)

INTERIOR SURFACE COLOR: red

EXTERIOR SURFACE COLOR: red

WALL THICKNESS (IN MM): rim, $4.1 \mathrm{~mm}$

INTERIOR SURFACE TREATMENT: burnished

EXTERIOR SURFACE TREATMENT: burnished; fire clouds on the body

HEIGHT (IN CM): 4.4

ORIFICE DIAMETER (IN CM): 6.4

DIAMETER AT BOTTOM OF RIM OR NECK (IN

CM): 5.1

BASE DIAMETER (IN CM) AND SHAPE OF

BASE: $3.1 \mathrm{~cm}$, circular and flat

ESTIMATED VOLUME (IN LITERS): 0.2

DECORATION (INCLUDING MOTIF AND ELEMENTS WHEN APPARENT): The rim has a continuous negative curvilinear scroll motif repeated six times around the vessel; the negative scrolls are created by excising selected areas of the red-slipped exterior surface. To either side of the negative scrolls are six small negative circle elements (Figure 8).

PIGMENT USE AND LOCATION ON VESSEL: none

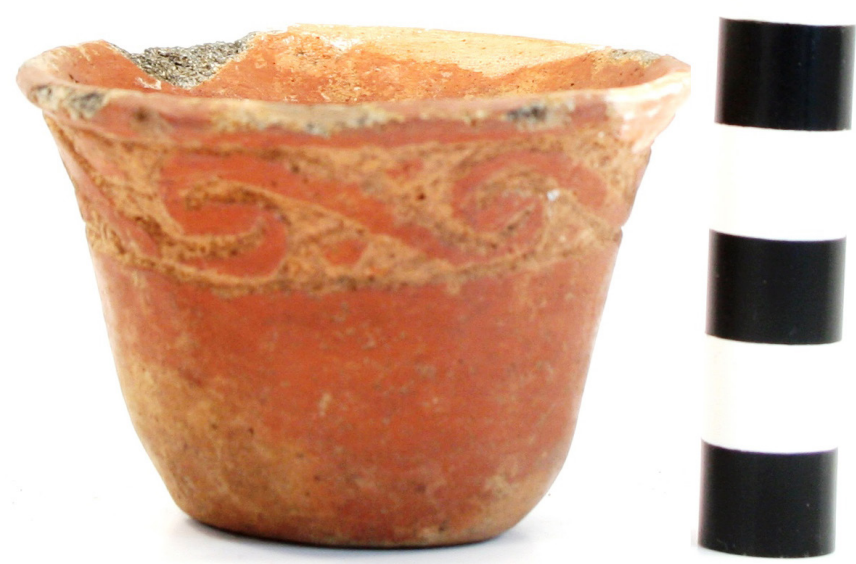

Figure 8. Taylor Engraved miniature deep bowl, GTW-126.

TYPE AND VARIETY (IF KNOWN): Taylor Engraved 
SITE NAME OR SITE NUMBER: George T. Wright Collection, Red River County, Texas

VESSEL NO.: GTW-128 [TX 072/1], B. R. R.

VESSEL FORM: Deep bowl (Figure 9)

NON-PLASTICS AND PASTE: shell

RIM AND LIP FORM: Direct rim and rounded lip

CORE COLOR: F (fired in a reducing environment and cooled in the open air)

INTERIOR SURFACE COLOR: red

EXTERIOR SURFACE COLOR: red

WALL THICKNESS (IN MM): rim, $4.8 \mathrm{~mm}$

INTERIOR SURFACE TREATMENT: burnished

EXTERIOR SURFACE TREATMENT: burnished

HEIGHT (IN CM): 12.7

ORIFICE DIAMETER (IN CM): 13.8

DIAMETER AT BOTTOM OF RIM OR NECK (IN CM): 13.6

BASE DIAMETER (IN CM) AND SHAPE OF BASE: $9.5 \mathrm{~cm}$, circular and flat

ESTIMATED VOLUME (IN LITERS): 1.4

DECORATION (INCLUDING MOTIF AND ELEMENTS WHEN APPARENT): the rim panel is defined by two upper horizontal engraved lines and one lower horizontal engraved line. Between these lines are 16 upper and lower triangle elements formed by narrow hatched zones (Figure 9). Within each triangle are single smaller triangle elements with excised corners and negative oval elements (see Suhm and Jelks 1962:Plate 2i).

PIGMENT USE AND LOCATION ON VESSEL:

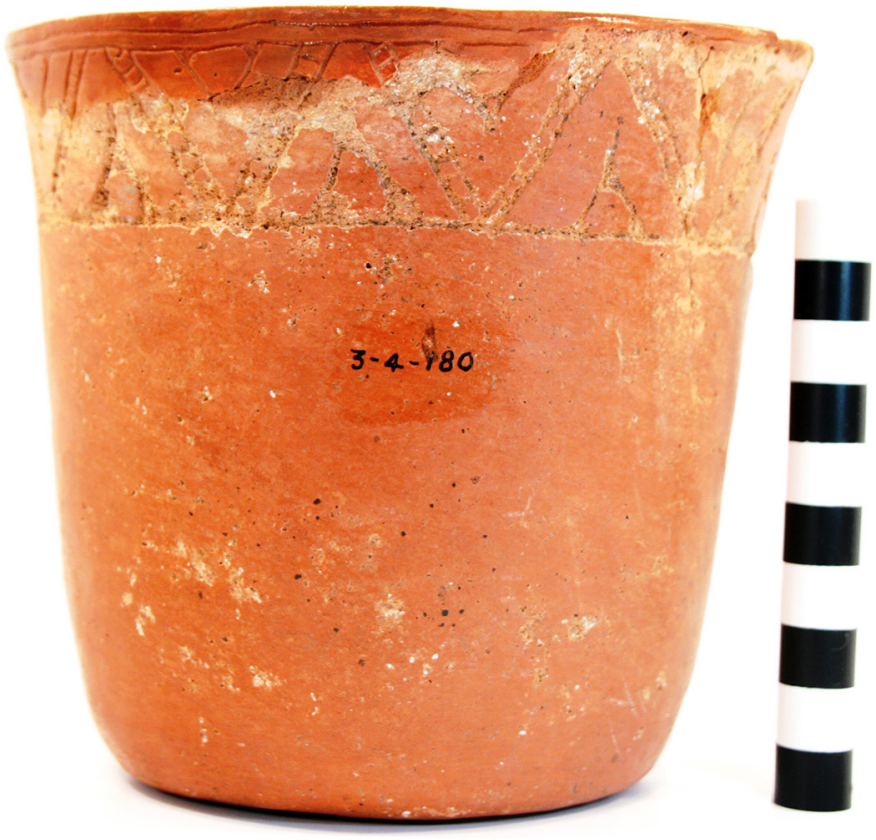

Figure 9. Avery Engraved deep bowl, GTW-128. none

TYPE AND VARIETY (IF KNOWN): Avery Engraved (Suhm and Jelks 1962:1-4) 
SITE NAME OR SITE NUMBER: George T. Wright Collection, Red River County, Texas

VESSEL NO.: GTW-134 [TX 073/1], B. R. R.

VESSEL FORM: Deep bowl

NON-PLASTICS AND PASTE: shell

RIM AND LIP FORM: Direct rim and rounded lip

CORE COLOR: F (fired in a reducing environment and cooled in the open air)

INTERIOR SURFACE COLOR: red; fire cloud on the base

EXTERIOR SURFACE COLOR: red; fire cloud on the base

WALL THICKNESS (IN MM): rim, $4.9 \mathrm{~mm}$; body, $4.6 \mathrm{~mm}$; base, $5.9 \mathrm{~mm}$

INTERIOR SURFACE TREATMENT: smoothed

EXTERIOR SURFACE TREATMENT: smoothed

HEIGHT (IN CM): N/A; rim height is $4.8 \mathrm{~cm}$

ORIFICE DIAMETER (IN CM): 14.0

DIAMETER AT BOTTOM OF RIM OR NECK (IN CM): 14.0

BASE DIAMETER (IN CM) AND SHAPE OF BASE: N/A

ESTIMATED VOLUME (IN LITERS): N/A

DECORATION (INCLUDING MOTIF AND ELEMENTS WHEN APPARENT): The vessel has a red slip on its exterior surface. The engraved rim panel has single upper and lower horizontal engraved lines, and the panel itself is divided by an unknown number (probably four) of vertical excised brackets. Between each of the brackets are a series of concentric semi-circular engraved lines (Figure 10).

PIGMENT USE AND LOCATION ON VESSEL: GTW-134. none

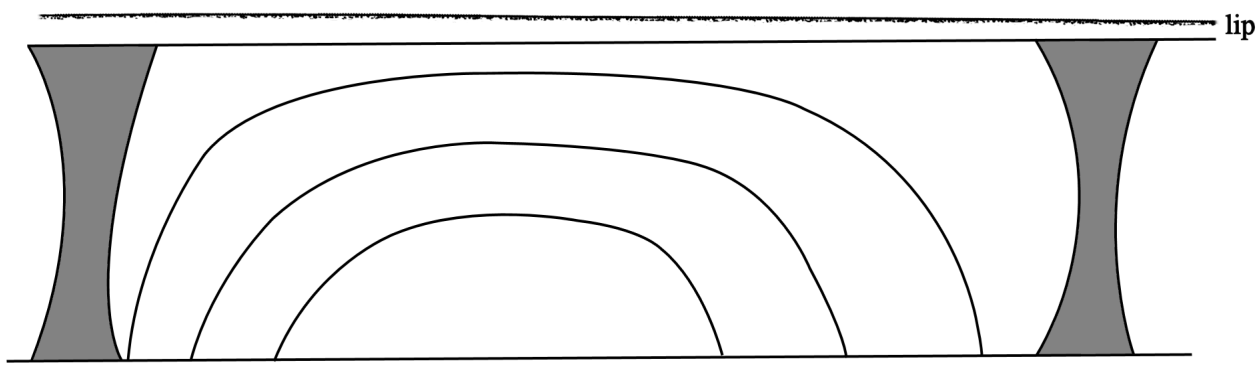

Figure 10. Decorative elements on Avery Engraved, var. Graves deep bowl, TYPE AND VARIETY (IF KNOWN): Avery Engraved, var. Graves (see Schambach and Miller 1984:119 and Figure 11-6) 
SITE NAME OR SITE NUMBER: George T. Wright Collection, Red River County, Texas

VESSEL NO.: GTW-135 [TX 074/1], B. R. R.

VESSEL FORM: Jar with four rim peaks (Figure 11)

NON-PLASTICS AND PASTE: shell

RIM AND LIP FORM: Everted rim and rounded lip

CORE COLOR: F (fired in a reducing environment and cooled in the open air]

INTERIOR SURFACE COLOR: red

EXTERIOR SURFACE COLOR: red

WALL THICKNESS (IN MM): rim, $4.5 \mathrm{~mm}$

INTERIOR SURFACE TREATMENT: smoothed

EXTERIOR SURFACE TREATMENT: smoothed

HEIGHT (IN CM): 14.5

ORIFICE DIAMETER (IN CM): 12.5

DIAMETER AT BOTTOM OF RIM OR NECK

(IN CM): 8.9

BASE DIAMETER (IN CM) AND SHAPE OF

BASE: $7.0 \mathrm{~cm}$, circular and flat

ESTIMATED VOLUME (IN LITERS): 1.1

DECORATION (INCLUDING MOTIF AND ELEMENTS WHEN APPARENT): The interior and exterior surfaces of the vessel have a red slip, which is a unique feature of this Nash Neck Banded vessel. There are two horizontal neck banded rows on the rim, along with a single tool punctated row at the rim-body juncture. There are short appliqued ridges on the rim under each of the rim peaks. The vessel body is red-slipped, but otherwise not decorated (Figure 11).

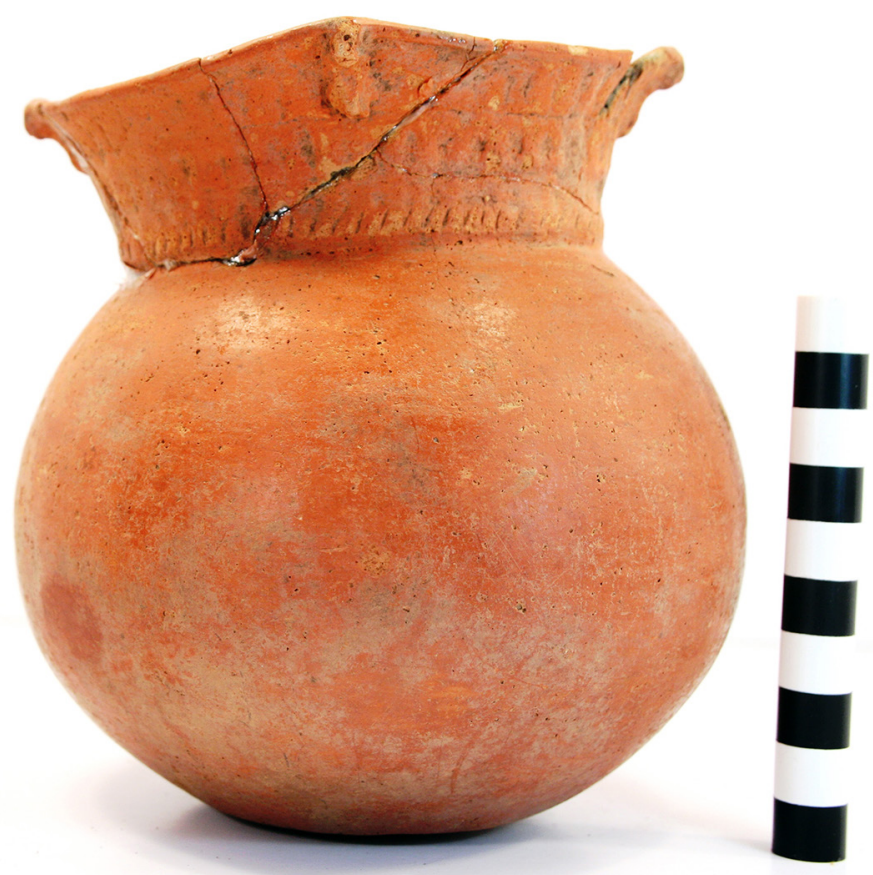

Figure 11. Red-slipped Nash Neck Banded jar, GTW-135.

PIGMENT USE AND LOCATION ON VESSEL: none

TYPE AND VARIETY (IF KNOWN): Nash Neck Banded (Suhm and Jelks 1962:111 and Plate 56) 
SITE NAME OR SITE NUMBER: George T. Wright Collection, Red River County, Texas

VESSEL NO.: GTW-159 [TX 075/1], B. R. R.

VESSEL FORM: Bottle with a spool neck and a short pedestal base (Figure 12)

NON-PLASTICS AND PASTE: shell

RIM AND LIP FORM: Everted rim and rounded lip

CORE COLOR: F (fired in a reducing environment and cooled in the open air)

INTERIOR SURFACE COLOR: yellowish-brown

EXTERIOR SURFACE COLOR: yellowish-brown; fire clouds on the rim and body

WALL THICKNESS (IN MM): rim, $7.1 \mathrm{~mm}$

INTERIOR SURFACE TREATMENT: none

EXTERIOR SURFACE TREATMENT: smoothed

HEIGHT (IN CM): 10.8

ORIFICE DIAMETER (IN CM): 4.3

DIAMETER AT BOTTOM OF RIM OR NECK (IN CM): 4.9

BASE DIAMETER (IN CM) AND SHAPE OF BASE: $7.0 \mathrm{~cm}$, circular flat; the pedestal base stands $2.3 \mathrm{~mm}$ in height.

ESTIMATED VOLUME (IN LITERS): 0.3

DECORATION (INCLUDING MOTIF AND ELEMENTS WHEN APPARENT): The vessel body has a series of curvilinear interlocking engraved scrolls filled with incised lines pitched in different decorations. Inside each scroll element are four engraved circles surrounded by incised lines (Figure 12).

PIGMENT USE AND LOCATION ON VESSEL: none

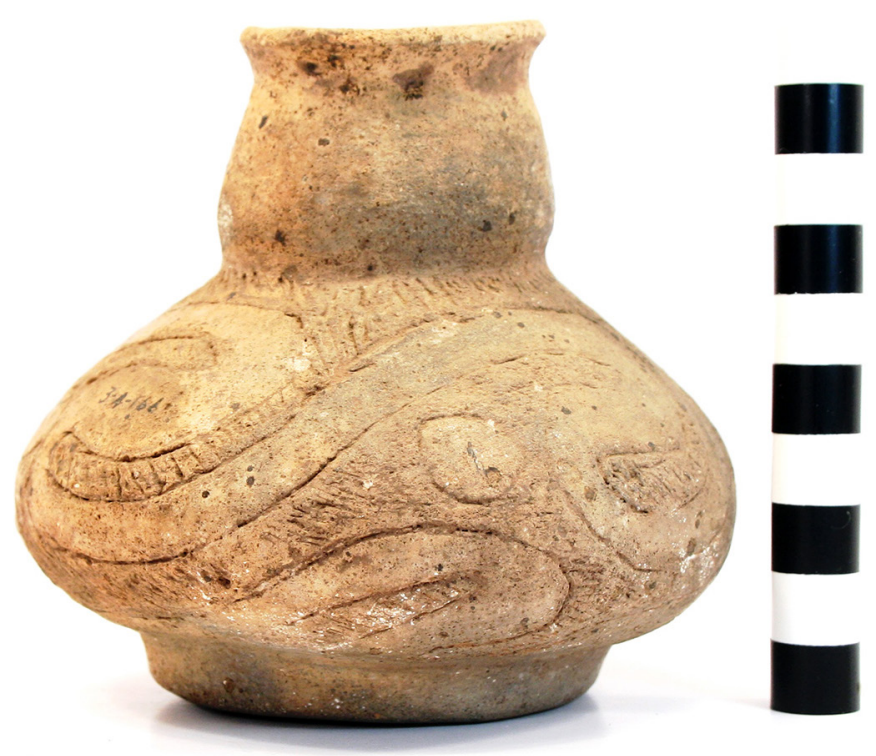

Figure 12. Hudson Engraved bottle, GTW-159.

TYPE AND VARIETY (IF KNOWN): Hudson Engraved 
SITE NAME OR SITE NUMBER: George T. Wright Collection, Red River County, Texas

VESSEL NO.: GTW-160 [TX 076/1], B. R. R.

VESSEL FORM: Bottle with a spool neck and a short pedestal base (Figure 13)

NON-PLASTICS AND PASTE: shell

RIM AND LIP FORM: Everted rim and rounded lip

CORE COLOR: B (fired and cooled in a reducing environment]

INTERIOR SURFACE COLOR: very dark grayish-brown

EXTERIOR SURFACE COLOR: very dark grayish-brown

WALL THICKNESS (IN MM): rim, $5.1 \mathrm{~mm}$

INTERIOR SURFACE TREATMENT: none

EXTERIOR SURFACE TREATMENT: burnished

HEIGHT (IN CM): 11.4

ORIFICE DIAMETER (IN CM): 3.0

DIAMETER AT BOTTOM OF RIM OR NECK

(IN CM): $3.7 \mathrm{~cm}$, maximum body diameter: 8.8 $\mathrm{cm}$

BASE DIAMETER (IN CM) AND SHAPE OF BASE: $5.9 \mathrm{~cm}$, circular and concave; pedestal base stands $15 \mathrm{~mm}$ high

\section{ESTIMATED VOLUME (IN LITERS): 0.3}

DECORATION (INCLUDING MOTIF AND ELEMENTS WHEN APPARENT): The vessel body has a series of four curvilinear interlocking engraved scrolls filled with incised lines pitched in different decorations. Inside each scroll element are four engraved circles surrounded by incised lines (Figure 13).

PIGMENT USE AND LOCATION ON VESSEL: none

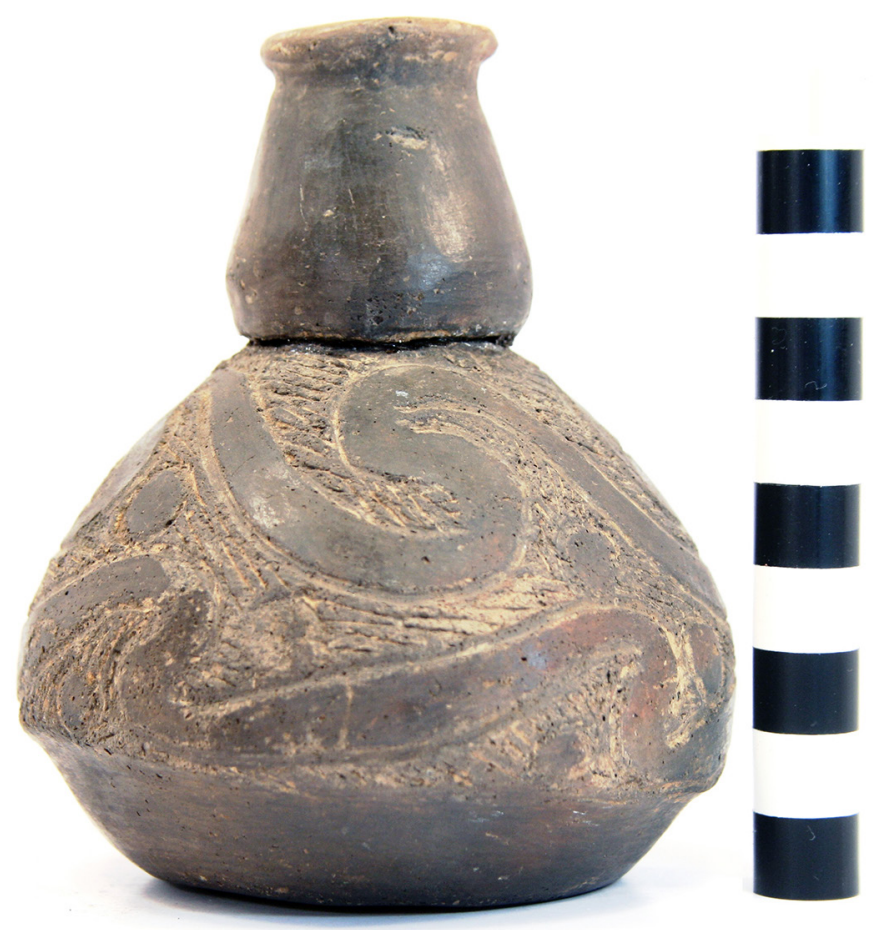

Figure 13. Hudson Engraved bottle with a spool neck, GTW-160.

TYPE AND VARIETY (IF KNOWN): Hudson Engraved

SITE NAME OR SITE NUMBER: George T. Wright Collection, Red River County, Texas 
VESSEL NO.: GTW-167 [TX 077/1], B. R. R.

VESSEL FORM: Bottle with a spool neck (Figure 14)

NON-PLASTICS AND PASTE: shell

RIM AND LIP FORM: Everted rim and rounded, exterior folded lip

CORE COLOR: B (fired and cooled in a reducing environment)

INTERIOR SURFACE COLOR: very dark grayish-brown

EXTERIOR SURFACE COLOR: very dark grayish-brown; fire clouds on the body

WALL THICKNESS (IN MM): rim, $6.0 \mathrm{~mm}$

INTERIOR SURFACE TREATMENT: none

EXTERIOR SURFACE TREATMENT: burnished

HEIGHT (IN CM): 8.3

ORIFICE DIAMETER (IN CM): 3.1

DIAMETER AT BOTTOM OF RIM OR NECK (IN

$\mathrm{CM}): 3.4$; maximum body diameter: $7.6 \mathrm{~cm}$

BASE DIAMETER (IN CM) AND SHAPE OF

BASE: $3.7 \mathrm{~cm}$, circular and rounded

ESTIMATED VOLUME (IN LITERS): 0.13

DECORATION (INCLUDING MOTIF AND

ELEMENTS WHEN APPARENT): The vessel body has a series of four curvilinear and interlocking engraved scrolls filled with incised lines pitched in different decorations. Inside each scroll element are a total of four engraved circles surrounded by incised lines (Figure 14).

PIGMENT USE AND LOCATION ON VESSEL: none

TYPE AND VARIETY (IF KNOWN): Hudson Engraved

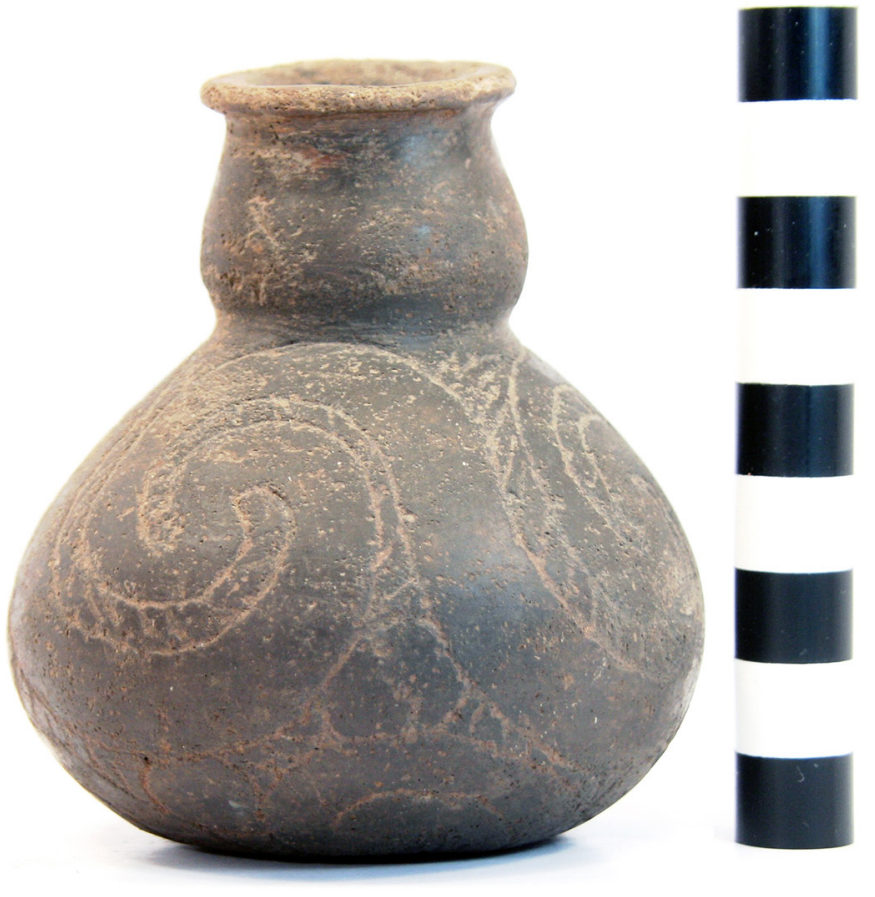

Figure 14. Hudson Engraved bottle with a spool neck, GTW-167. 
SITE NAME OR SITE NUMBER: George T. Wright Collection, Red River County, Texas

VESSEL NO.: GTW-184 [TX 078/1], B. R. R.

VESSEL FORM: Bottle with a spool neck (Figure 15)

NON-PLASTICS AND PASTE: shell

RIM AND LIP FORM: Everted rim and rounded lip

CORE COLOR: B (fired and cooled in a reducing environment)

INTERIOR SURFACE COLOR: very dark grayish-brown

EXTERIOR SURFACE COLOR: very dark grayish-brown

WALL THICKNESS (IN MM): rim, 3.4 mm

INTERIOR SURFACE TREATMENT: none

EXTERIOR SURFACE TREATMENT: burnished

HEIGHT (IN CM): 12.7

ORIFICE DIAMETER (IN CM): 3.3

DIAMETER AT BOTTOM OF RIM OR NECK

(IN CM): 4.3 ; maximum body diameter: $10.6 \mathrm{~cm}$

BASE DIAMETER (IN CM) AND SHAPE OF

BASE: $4.5 \mathrm{~cm}$, circular and rounded

ESTIMATED VOLUME (IN LITERS): 0.2

DECORATION (INCLUDING MOTIF AND

ELEMENTS WHEN APPARENT): The vessel

body has a series of three curvilinear and

interlocking engraved scrolls filled with incised

lines pitched in different decorations. Inside each

scroll element are a total of three engraved circles

surrounded by incised lines. The vessel also has a lip

notched rim notched from right to left (Figure 15).

PIGMENT USE AND LOCATION ON VESSEL: none

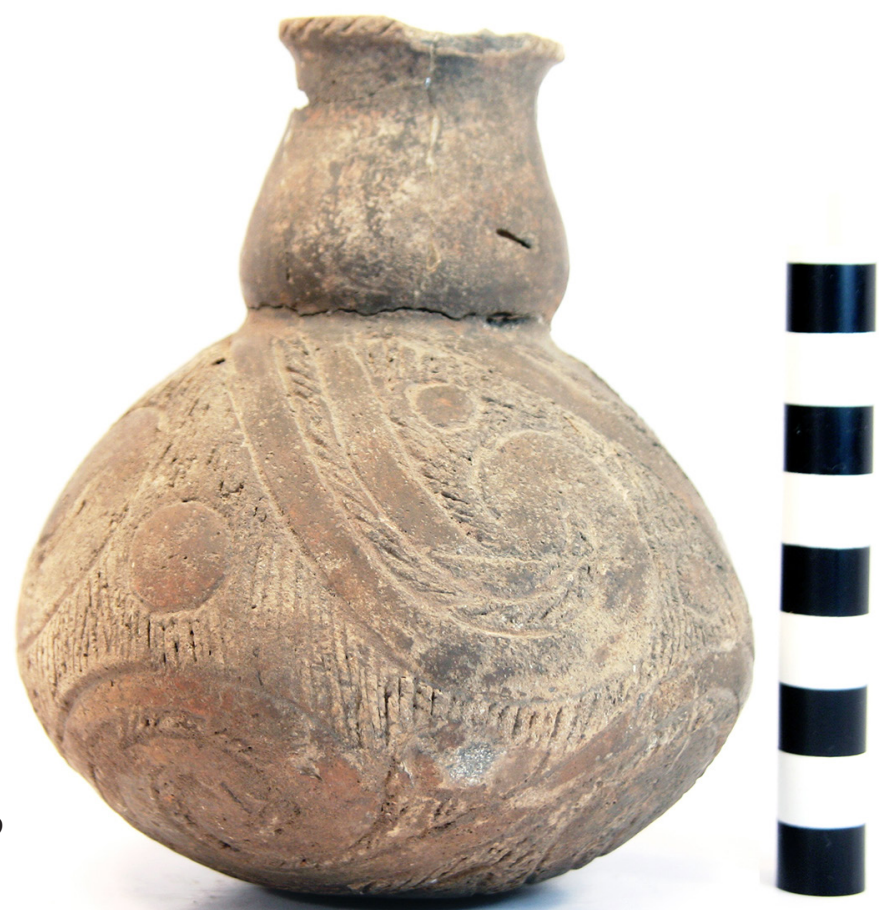

Figure 15. Hudson Engraved bottle with a spool neck, GTW-184.

TYPE AND VARIETY (IF KNOWN): Hudson Engraved 
SITE NAME OR SITE NUMBER: George T. Wright Collection, Red River County, Texas

VESSEL NO.: GTW-189 [TX 079/1], B. R. R.

VESSEL FORM: Bottle with a spool neck (Figure 16)

NON-PLASTICS AND PASTE: shell

RIM AND LIP FORM: Direct rim and rounded, exterior folded lip

CORE COLOR: $\mathrm{G}$ (fired in a reducing environment and cooled in the open air)

INTERIOR SURFACE COLOR: very dark brown

EXTERIOR SURFACE COLOR: dark brown

WALL THICKNESS (IN MM): rim, $4.2 \mathrm{~mm}$

INTERIOR SURFACE TREATMENT: none

EXTERIOR SURFACE TREATMENT: burnished

HEIGHT (IN CM): 11.5

ORIFICE DIAMETER (IN CM): 3.2

DIAMETER AT BOTTOM OF RIM OR NECK (IN CM): 3.6 ; maximum body diameter: $9.9 \mathrm{~cm}$

BASE DIAMETER (IN CM) AND SHAPE OF BASE: $3.7 \mathrm{~cm}$, circular and rounded

ESTIMATED VOLUME (IN LITERS): 0.2

DECORATION (INCLUDING MOTIF AND ELEMENTS WHEN APPARENT): The vessel body has four upper and lower sets of curvilinear and interlocking engraved scrolls that end in hooked arm elements (Figure 16; see also Suhm and Jelks 1962:Plate 76a).

PIGMENT USE AND LOCATION ON VESSEL: none

TYPE AND VARIETY (IF KNOWN): Taylor

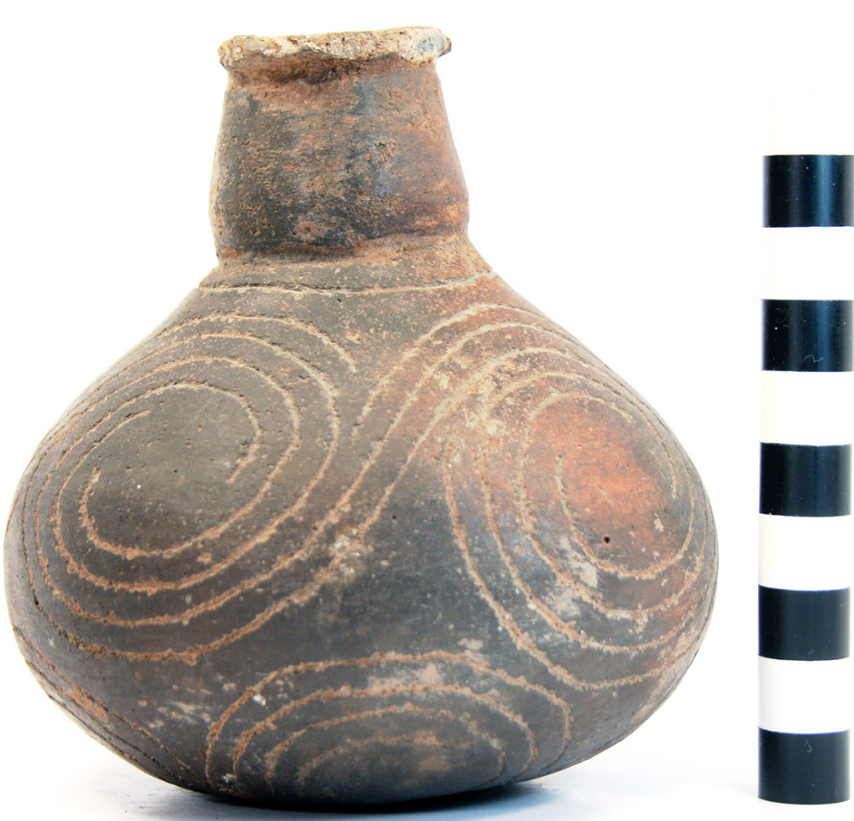

Figure 16. Taylor Engraved bottle with a spool neck, GTW-189. Engraved 
SITE NAME OR SITE NUMBER: George T. Wright Collection, Red River County, Texas

VESSEL NO.: GTW-210 [TX 081/1], S. R. R. [Surface, Red River County]

VESSEL FORM: Bottle with a spool neck (Figure 17)

NON-PLASTICS AND PASTE: shell

RIM AND LIP FORM: Everted rim and rounded lip

CORE COLOR: $\mathrm{G}$ (fired in a reducing environment and cooled in the open air)

INTERIOR SURFACE COLOR: dark grayish-brown

EXTERIOR SURFACE COLOR: brown; fire clouds on the rim, body, and base

WALL THICKNESS (IN MM): rim, $5.1 \mathrm{~mm}$

INTERIOR SURFACE TREATMENT: none

EXTERIOR SURFACE TREATMENT:

burnished

HEIGHT (IN CM): 14.3

ORIFICE DIAMETER (IN CM): 3.7

DIAMETER AT BOTTOM OF RIM OR NECK

(IN CM): 4.0; maximum body diameter: $9.9 \mathrm{~cm}$

BASE DIAMETER (IN CM) AND SHAPE OF

BASE: $3.1 \mathrm{~cm}$, circular and rounded

ESTIMATED VOLUME (IN LITERS): 0.2

DECORATION (INCLUDING MOTIF AND ELEMENTS WHEN APPARENT): The vessel body has a series of four curvilinear and interlocking engraved scrolls filled with incised lines pitched in different decorations. Surrounding the vessel base are a series of four scroll elements and a large negative circle (Figure 17). The vessel also has a right to left lip notched rim.

PIGMENT USE AND LOCATION ON

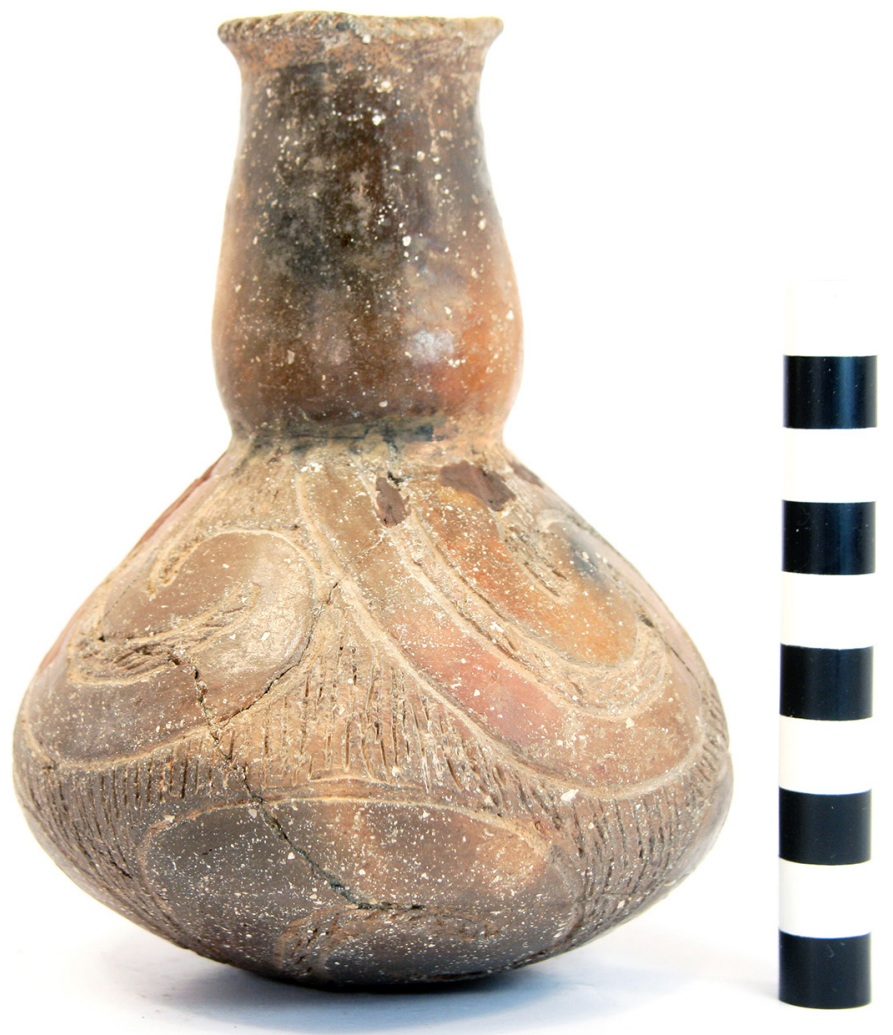

Figure 17. Hudson Engraved bottle with a spool neck, GTW-210.

VESSEL: none

TYPE AND VARIETY (IF KNOWN): Hudson Engraved 
SITE NAME OR SITE NUMBER: George T. Wright Collection

VESSEL NO.: GTW-224, B. R. R.

VESSEL FORM: Bottle (Figure 18a)

NON-PLASTICS AND PASTE: grog

RIM AND LIP FORM: Direct rim and rounded lip

CORE COLOR: $\mathrm{F}$ (fired in a reducing environment and cooled in the open air)

INTERIOR SURFACE COLOR: yellowish-brown

EXTERIOR SURFACE COLOR: yellowish-brown; fire clouds on the rim and body

WALL THICKNESS (IN MM): rim, $5.1 \mathrm{~mm}$

INTERIOR SURFACE TREATMENT: none

EXTERIOR SURFACE TREATMENT: burnished

HEIGHT (IN CM): 20.9

ORIFICE DIAMETER (IN CM): 3.3

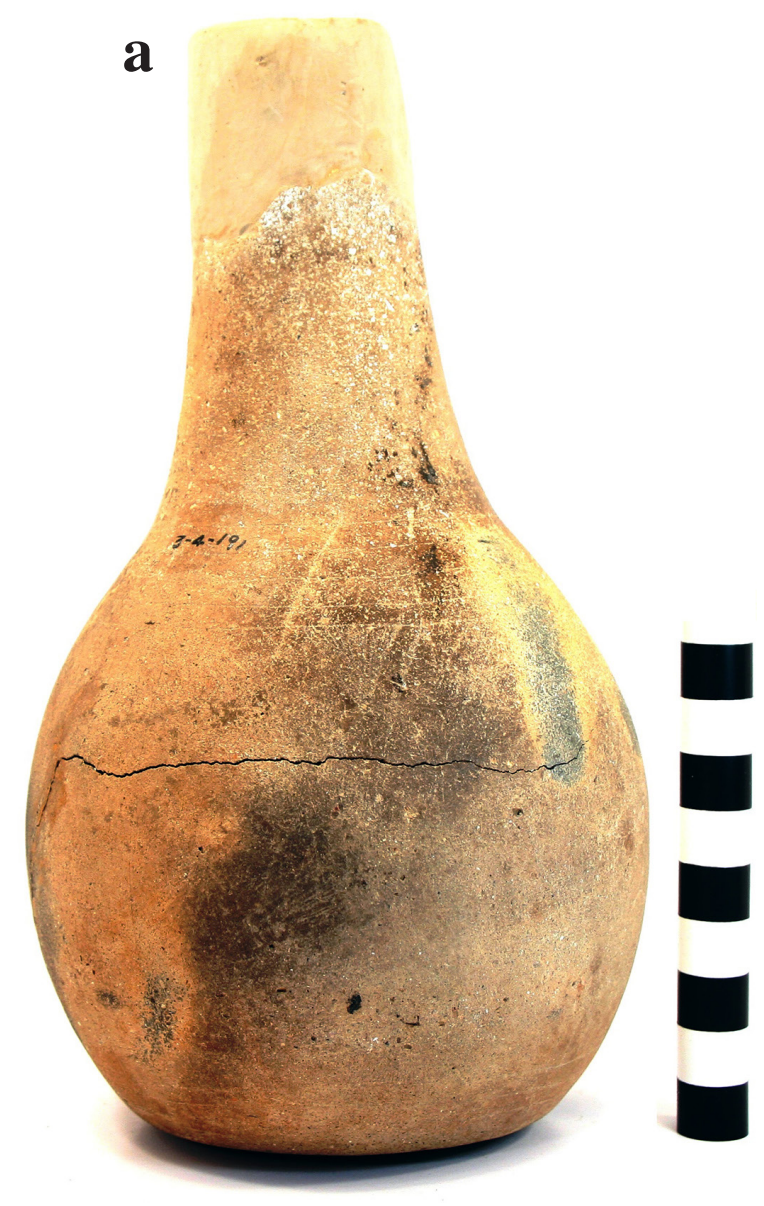

DIAMETER AT BOTTOM OF RIM OR NECK (IN CM): 6.1; maximum body diameter: $11.3 \mathrm{~cm}$

BASE DIAMETER (IN CM) AND SHAPE OF BASE: 8.0, circular and flat

\section{ESTIMATED VOLUME (IN LITERS): 0.7}

\section{DECORATION (INCLUDING MOTIF AND ELEMENTS}

WHEN APPARENT): The upper and lower parts of the body panel have five and three closely-spaced horizontal engraved lines, respectively. The remainder of the vessel body is divided into four vertical panels by excised pendant elements. These panels have a series of five vertical engraved lines and four sideways executed concentric semi-circular engraved lines (Figure 18a-b).

\section{PIGMENT USE AND LOCATION ON VESSEL: none}

TYPE AND VARIETY (IF KNOWN): cf. Holly Fine Engraved b

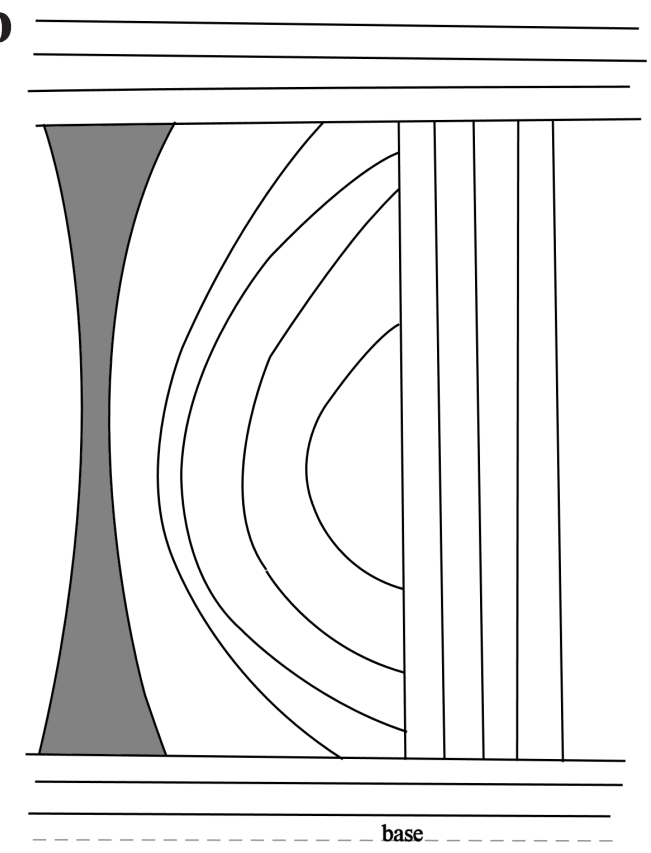

Figure 18. cf. Holly Fine Engraved bottle, GTW-224: a, photograph; b, decorative elements on the vessel body. (see Suhm and Jelks 1962:77-79) 
SITE NAME OR SITE NUMBER: George T. Wright Collection, Red River County, Texas

VESSEL NO.: GTW-232 \{TX 083/1], B. R. R.

VESSEL FORM: Bottle with a possible spool neck (Figure 19)

NON-PLASTICS AND PASTE: shell

RIM AND LIP FORM: N/A

CORE COLOR: B (fired and cooled in a reducing environment)

INTERIOR SURFACE COLOR: very dark grayish-brown

EXTERIOR SURFACE COLOR: very dark grayish-brown

WALL THICKNESS (IN MM): rim, $8.3 \mathrm{~mm}$

INTERIOR SURFACE TREATMENT: none

EXTERIOR SURFACE TREATMENT: burnished

HEIGHT (IN CM): 14.6+

ORIFICE DIAMETER (IN CM): 4.4

DIAMETER AT BOTTOM OF RIM OR NECK

(IN CM): 4.9; maximum body diameter: $16.0 \mathrm{~cm}$

BASE DIAMETER (IN CM) AND SHAPE OF BASE: $5.9 \mathrm{~cm}$, circular and concave

ESTIMATED VOLUME (IN LITERS): 0.3+

DECORATION (INCLUDING MOTIF AND ELEMENTS WHEN APPARENT): The vessel body has four curvilinear and interlocking engraved scrolls filled with incised lines pitched in different directions. There are sets of three upper and four lower open engraved triangles in the scrolls (Figure 19).

PIGMENT USE AND LOCATION ON

VESSEL: none

TYPE AND VARIETY (IF KNOWN): Hudson Engraved

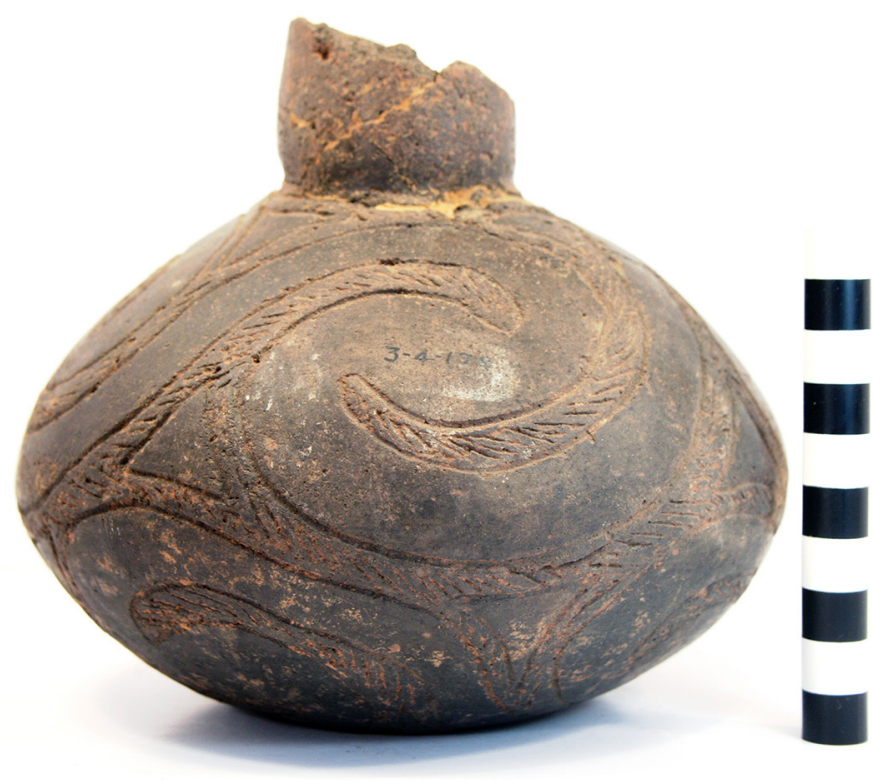

Figure 19. Hudson Engraved bottle with a possible spool neck, GTW-232. 
SITE NAME OR SITE NUMBER: George T. Wright Collection, Red River County, Texas. Wright's notebook indicates this vessel came from a ditch on a site near Ward's Creek, four miles east of Detroit, Texas. This site is in the upper Sulphur River basin.

VESSEL NO.: GTW-234 [TX 084/1], S. R. R.

VESSEL FORM: Bottle (Figure 20)

NON-PLASTICS AND PASTE: grog, bone, and hematite

RIM AND LIP FORM: Direct rim and rounded lip

CORE COLOR: F (fired in a reducing environment and cooled in the open air)

INTERIOR SURFACE COLOR: yellowish-brown

EXTERIOR SURFACE COLOR: yellowish-brown; fire clouds on the rim, body, and base

WALL THICKNESS (IN MM): rim, $6.5 \mathrm{~mm}$

INTERIOR SURFACE TREATMENT: none

EXTERIOR SURFACE TREATMENT: none

HEIGHT (IN CM): 17.6

ORIFICE DIAMETER (IN CM): 3.7

DIAMETER AT BOTTOM OF RIM OR NECK (IN $\mathrm{CM}$ ): 5.3 ; maximum body diameter: $8.8 \mathrm{~cm}$

BASE DIAMETER (IN CM) AND SHAPE OF BASE:

$6.4 \mathrm{~cm}$, circular and flat

ESTIMATED VOLUME (IN LITERS): 0.45

DECORATION (INCLUDING MOTIF AND

ELEMENTS WHEN APPARENT): Plain (Figure 20)

PIGMENT USE AND LOCATION ON VESSEL: none

TYPE AND VARIETY (IF KNOWN): Unidentified plain ware

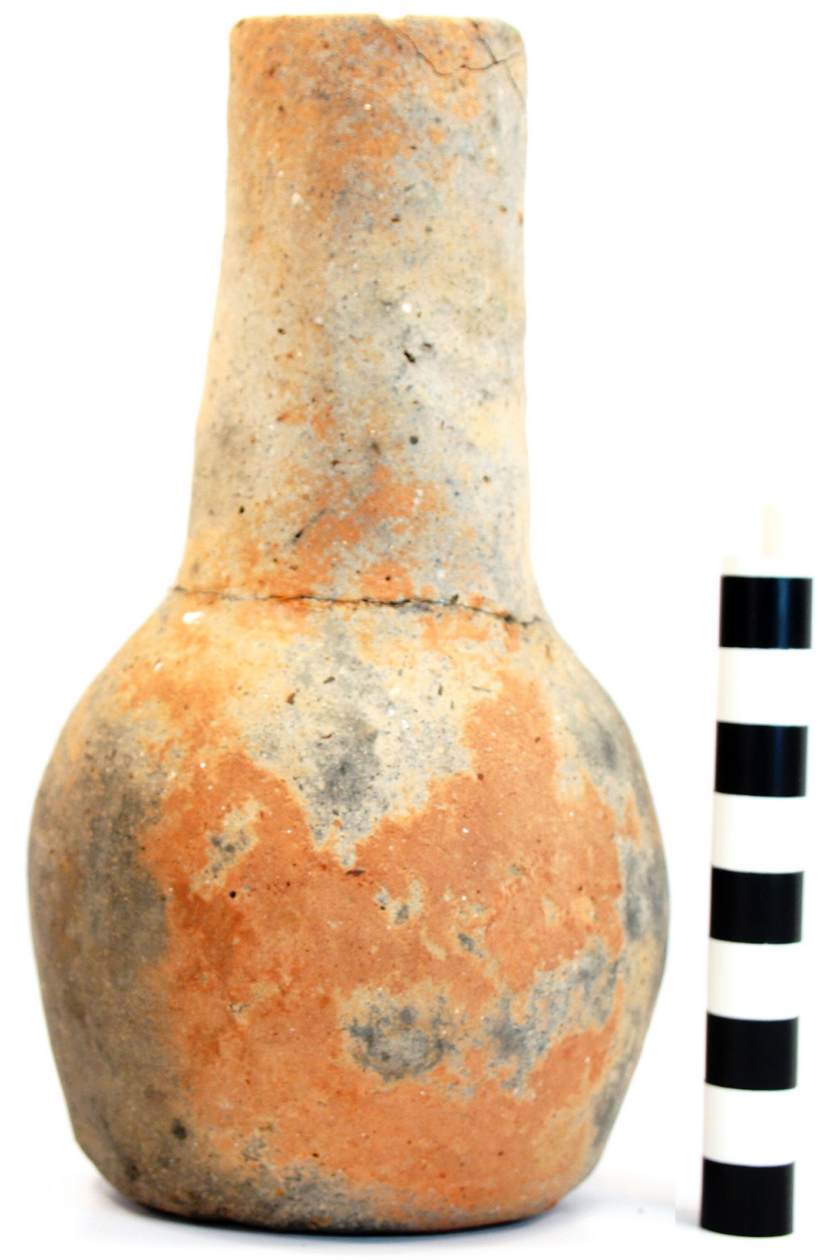

Figure 20. Plain bottle, GTW-234. 
SITE NAME OR SITE NUMBER: George T. Wright Collection, Red River County, Texas

VESSEL NO.: GTW-239 [TX 085/1], B. R. R.

VESSEL FORM: Bottle with a carinated body (Figure 21)

NON-PLASTICS AND PASTE: shell

RIM AND LIP FORM: N/A

CORE COLOR: B (fired and cooled in a reducing environment)

INTERIOR SURFACE COLOR: very dark grayish-brown

EXTERIOR SURFACE COLOR: very dark grayish-brown

WALL THICKNESS (IN MM): neck, $4.4 \mathrm{~mm}$

INTERIOR SURFACE TREATMENT: none

EXTERIOR SURFACE TREATMENT: burnished

HEIGHT (IN CM): 16.2+

ORIFICE DIAMETER (IN CM): 3.9

DIAMETER AT BOTTOM OF RIM OR NECK (IN

$\mathrm{CM}$ ): 5.5 ; maximum body diameter: $11.8 \mathrm{~cm}$

BASE DIAMETER (IN CM) AND SHAPE OF

BASE: $5.0 \mathrm{~cm}$, circular and flat

ESTIMATED VOLUME (IN LITERS): 0.4+

DECORATION (INCLUDING MOTIF AND

ELEMENTS WHEN APPARENT): The upper and lower vessel body have either three or two horizontal engraved lines, respectively. The body panel has four sets of concentric circle elements with an inner circle that has a negative $\mathrm{S}$ element. There is a horizontal negative $\mathrm{S}$ element above the concentric circles, and each concentric circle is connected at its base with two short sets of curvilinear engraved lines. The body panel is divided into the four sets by narrow zones with a vertical negative $S$ engraved element and an upper bracket element with a negative oval

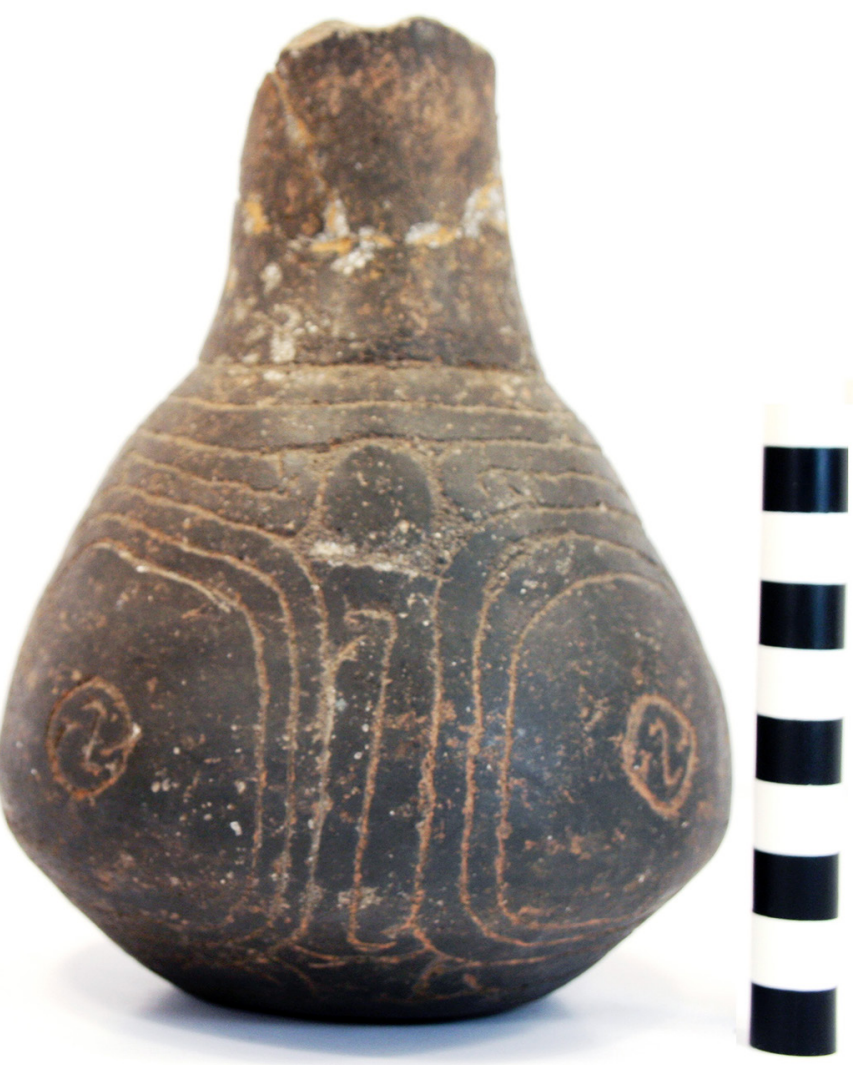

Figure 21. Avery Engraved bottle, GTW-239. defined by excised areas (Figure 21).

PIGMENT USE AND LOCATION ON VESSEL: none 
SITE NAME OR SITE NUMBER: George T. Wright Collection, Red River County, Texas

VESSEL NO.: GTW-241, B. R. R.

VESSEL FORM: Bottle (Figure 22)

NON-PLASTICS AND PASTE: shell

RIM AND LIP FORM: Direct rim and rounded lip

CORE COLOR: $\mathrm{H}$ (fired in a reducing environment and cooled in the open air)

INTERIOR SURFACE COLOR: reddish-brown

EXTERIOR SURFACE COLOR: dark grayish-brown

WALL THICKNESS (IN MM): rim, $3.9 \mathrm{~mm}$

INTERIOR SURFACE TREATMENT: none

EXTERIOR SURFACE TREATMENT: burnished

HEIGHT (IN CM): 16.4

ORIFICE DIAMETER (IN CM): 3.7

DIAMETER AT BOTTOM OF RIM OR NECK (IN CM):

4.9; maximum body diameter: $11.3 \mathrm{~cm}$

BASE DIAMETER (IN CM) AND SHAPE OF BASE:

5.7 , circular and flat

ESTIMATED VOLUME (IN LITERS): 0.4

DECORATION (INCLUDING MOTIF AND ELEMENTS WHEN APPARENT): The vessel body has four sets of concentric circular interlocking engraved scrolls that end in hooked arm elements. The scrolls are divided at the top of the vessel by large open triangular elements, and are divided at the bottom by sets of curvilinear triangular elements (Figure 22).

PIGMENT USE AND LOCATION ON VESSEL: none TYPE AND VARIETY (IF KNOWN): Taylor Engraved

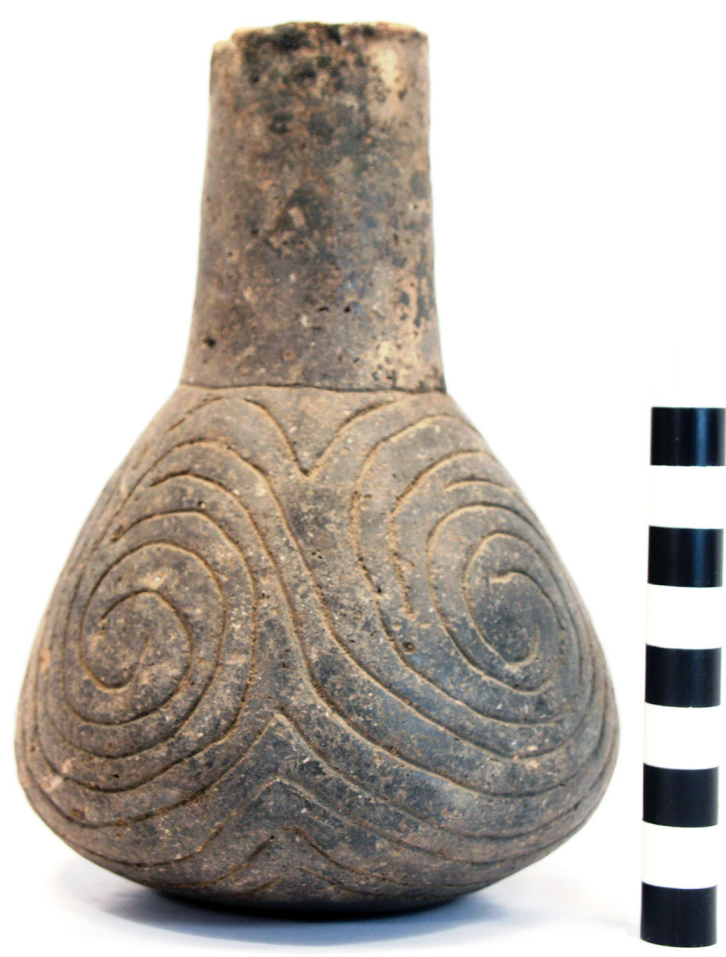

Figure 22. Taylor Engraved bottle, GTW-241. 
SITE NAME OR SITE NUMBER: George T. Wright Collection, Red River County, Texas

VESSEL NO.: GTW-243, B. R. R.

VESSEL FORM: Bottle with a spool neck (Figure 23)

NON-PLASTICS AND PASTE: shell

RIM AND LIP FORM: Direct rim and flat lip

CORE COLOR: B (fired and cooled in a reducing environment)

INTERIOR SURFACE COLOR: black

EXTERIOR SURFACE COLOR: black

WALL THICKNESS (IN MM): rim, 7.4 mm

INTERIOR SURFACE TREATMENT: none

EXTERIOR SURFACE TREATMENT: burnished

HEIGHT (IN CM): 17.1

ORIFICE DIAMETER (IN CM): 3.5

DIAMETER AT BOTTOM OF RIM OR NECK (IN

$\mathrm{CM}$ ): 4.0 ; maximum body diameter: $14.1 \mathrm{~cm}$

BASE DIAMETER (IN CM) AND SHAPE OF BASE: $5.6 \mathrm{~cm}$, circular and flat

ESTIMATED VOLUME (IN LITERS): 0.4

DECORATION (INCLUDING MOTIF AND ELEMENTS WHEN APPARENT): The vessel body has four sets of upper and lower interlocking concentric curvilinear engraved scrolls that end in hooked arm elements. The upper set of scrolls are divided by pendant triangles filled with diagonal lines, while the lower set of scrolls are divided by curvilinear triangular elements (Figure 23).

PIGMENT USE AND LOCATION ON VESSEL: none

TYPE AND VARIETY (IF KNOWN): Taylor

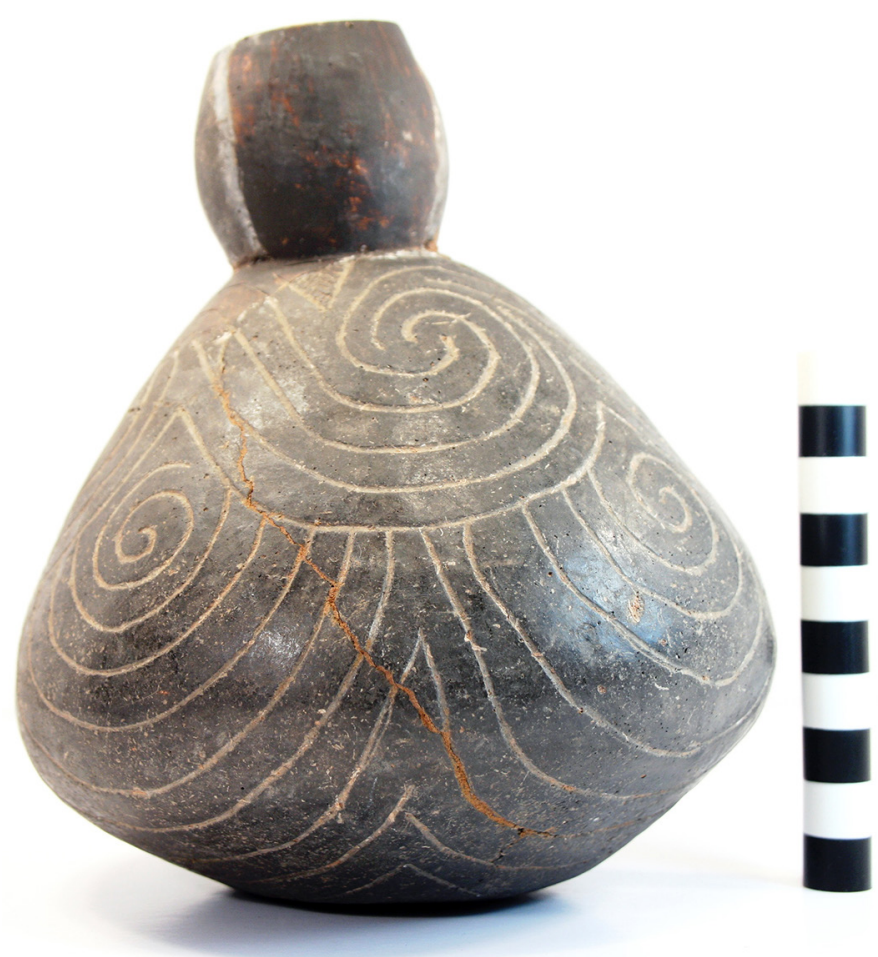

Figure 23. Taylor Engraved bottle with a spool neck, GTW-243. Engraved 
SITE NAME OR SITE NUMBER: George T. Wright Collection, Red River County, Texas

VESSEL NO.: GTW-292 [TX 090/1], B. R. R.

VESSEL FORM: Jar with four rim peaks (Figure 24)

NON-PLASTICS AND PASTE: grog

RIM AND LIP FORM: Direct rim and rounded lip

CORE COLOR: F (fired in a reducing environment and cooled in the open air)

INTERIOR SURFACE COLOR: yellowish-brown; fire clouds on the lower body; organic residue on the lower body

EXTERIOR SURFACE COLOR: yellowish-brown; fire clouds on the rim and body; organic residue on the rim and body

WALL THICKNESS (IN MM): rim, $6.3 \mathrm{~mm}$

INTERIOR SURFACE TREATMENT: smoothed

EXTERIOR SURFACE TREATMENT: smoothed on the body

HEIGHT (IN CM): 12.5

ORIFICE DIAMETER (IN CM): 8.3

DIAMETER AT BOTTOM OF RIM OR NECK (IN CM): 7.7

BASE DIAMETER (IN CM) AND SHAPE OF

BASE: $4.9 \mathrm{~cm}$, circular and flat

ESTIMATED VOLUME (IN LITERS): 0.6

DECORATION (INCLUDING MOTIF AND

ELEMENTS WHEN APPARENT): The rim has

two horizontal neck banded rows; the second neck

banded row has a row of diagonal tool punctations

pushed into the neck banding. There are short

vertical appliqued ridges under each rim peak. A broad horizontal incised line has been placed at the rim-body juncture (Figure 24).

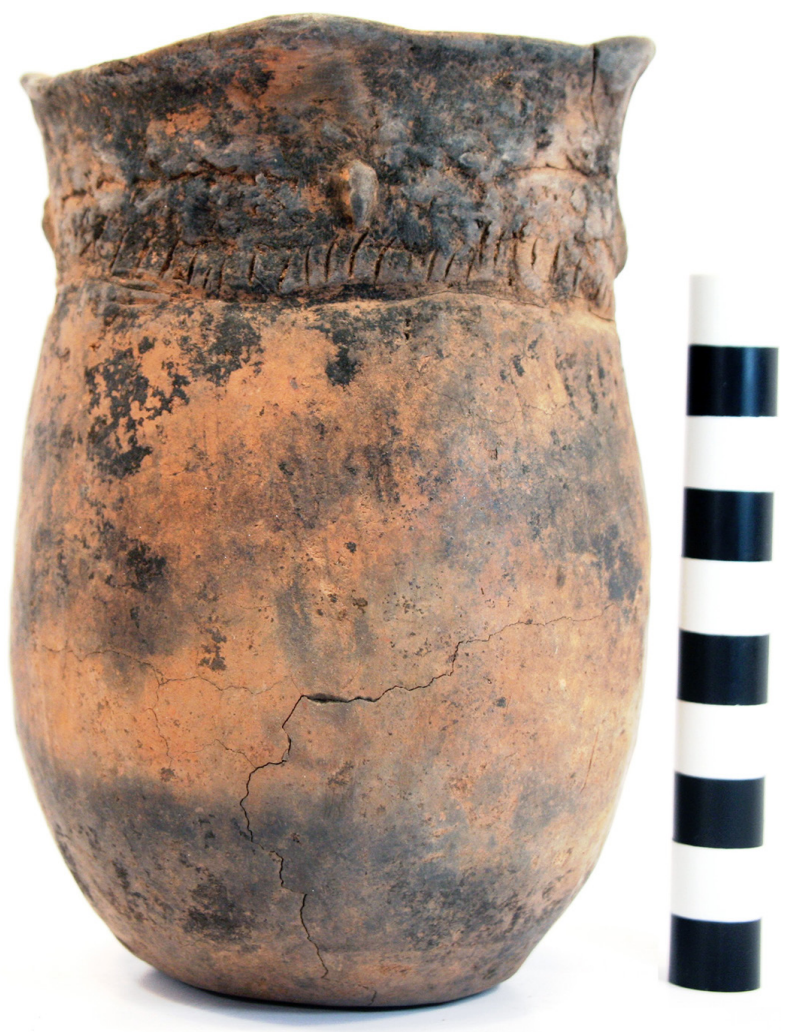

Figure 24. Nash Neck Banded jar with rim peaks, GTW-292.

PIGMENT USE AND LOCATION ON VESSEL: none

TYPE AND VARIETY (IF KNOWN): Nash Neck Banded 
SITE NAME OR SITE NUMBER: George T. Wright Collection, Lamar County, Texas. According to Wright's notebook (see also Wright 1943:92), this vessel was recovered in 1937 in a ditch along Auds Creek, about 10 miles south of Paris, Texas. Auds Creek flows south into the North Sulphur River in the upper Sulphur River basin,

VESSEL NO.: GTW-297 [TX 91/1]

VESSEL FORM: Jar (Figure 25a)

NON-PLASTICS AND PASTE: grog or sherd-tempered (see Appendix I)

RIM AND LIP FORM: Everted rim and flat lip

CORE COLOR: N/A

INTERIOR SURFACE COLOR: white

EXTERIOR SURFACE COLOR: white

WALL THICKNESS (IN MM): rim, $5.8 \mathrm{~mm}$

INTERIOR SURFACE TREATMENT: smoothed

EXTERIOR SURFACE TREATMENT: smoothed

HEIGHT (IN CM): 14.0

ORIFICE DIAMETER (IN CM): 11.8

DIAMETER AT BOTTOM OF RIM OR NECK (IN CM): 12.0 a

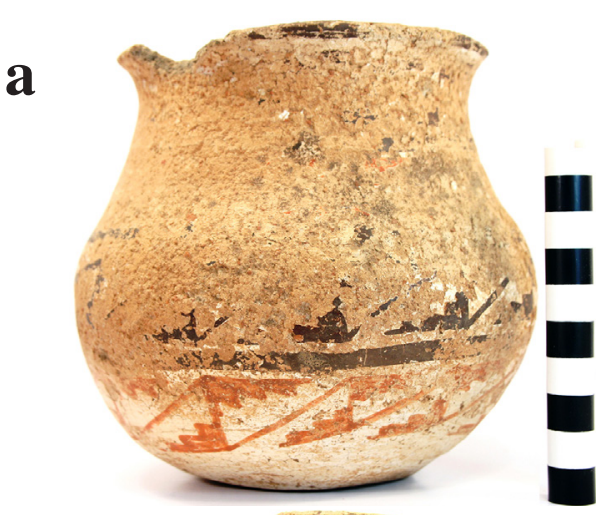

b

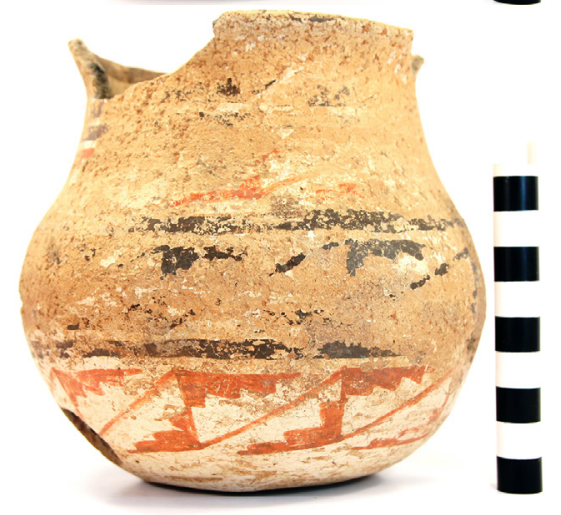

Figure 25. Painted Southwestern jar, GTW-297: a-b, different side views of the vessel.

BASE DIAMETER (IN CM) AND SHAPE OF BASE: $7.5 \mathrm{~cm}$, circular and flat

ESTIMATED VOLUME (IN LITERS): 1.0

DECORATION (INCLUDING MOTIF AND ELEMENTS WHEN APPARENT): The vessel has painted decorative elements, including being painted white on both vessel surfaces; the vessel is extensively eroded. There are four painted horizontal black bands dividing the vessel into sections, and between the bands are red and black stair-step elements and connecting diagonal painted lines (Figure 25a-b).

\section{PIGMENT USE AND LOCATION ON VESSEL: none}

TYPE AND VARIETY (IF KNOWN): Attributed to the Zuni, New Mexico ceramic tradition, based on an identification made by H. P. Mera of the University of New Mexico (Wright 1943:95). A recent examination of images of this vessel by Drs. Matt Peeples, Barbara Mills, and David Snow (July 2017 personal communication) has led them to conclude that it is not a Zuni vessel, but more like early to mid- $19^{\text {th }}$ century Keres Pueblo pottery. They also note that the shape of the vessel is more like Tewa vessels from the Rio Grande. "The painted lip is right for early to mid- $19^{\text {th }}$ century" age for the vessel. Overall, "1800-1880 is the most likely date range." However, the use of sherd temper and the character of the paste is consistent with a 19th century Zuni ceramic vessel (Matt Peeples, September 7, 2017 personal communication). Observations on the aplastics, paste, and paint of the vessel are provided by Matthew C. Pailles in Appendix I of this report. 
SITE NAME OR SITE NUMBER: George T. Wright Collection, Red River County, Texas

VESSEL NO.: GTW-298 [TX 092/1], B. R. R.

VESSEL FORM: Jar with four rim peaks (Figure 26)

NON-PLASTICS AND PASTE: shell

RIM AND LIP FORM: Everted rim and rounded lip

CORE COLOR: $\mathrm{G}$ (fired in a reducing environment and cooled in the open air)

INTERIOR SURFACE COLOR: grayish-brown

EXTERIOR SURFACE COLOR: dark yellowish-brown; fire clouds on the body

WALL THICKNESS (IN MM): rim, $6.2 \mathrm{~mm}$

INTERIOR SURFACE TREATMENT: none

EXTERIOR SURFACE TREATMENT: smoothed on the body

HEIGHT (IN CM): 12.8

ORIFICE DIAMETER (IN CM): 12.7

DIAMETER AT BOTTOM OF RIM OR NECK (IN CM): 10.3

BASE DIAMETER (IN CM) AND SHAPE OF BASE: $7.7 \mathrm{~cm}$, circular and flat

ESTIMATED VOLUME (IN LITERS): 1.0

DECORATION (INCLUDING MOTIF AND

ELEMENTS WHEN APPARENT): The vessel rim has two horizontal neck banded rows, as well as four short vertical appliqued ridges under each rim peak. The vessel body has four sets of two discontinuous vertical appliqued ridges placed underneath the vertical appliqued ridges on the vessel rim (Figure 26).

PIGMENT USE AND LOCATION ON VESSEL: none

TYPE AND VARIETY (IF KNOWN): Nash Neck Banded

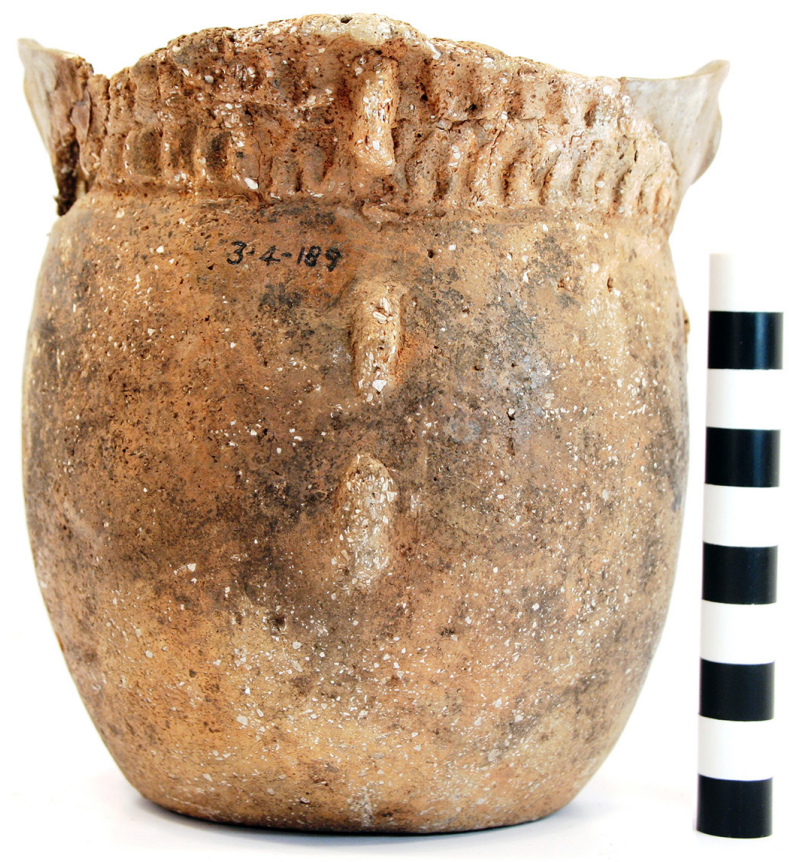

Figure 26. Nash Neck Banded jar with rim peaks, GTW-298. 
SITE NAME OR SITE NUMBER: George T. Wright Collection, Red River County, Texas VESSEL NO.: GTW-301 [TX 093/1], B. R. R.

VESSEL FORM: Jar (Figure 27)

NON-PLASTICS AND PASTE: grog

RIM AND LIP FORM: Everted rim and rounded lip

CORE COLOR: B (fired and cooled in a reducing environment)

INTERIOR SURFACE COLOR: very dark grayish-brown; fire clouds on the body

EXTERIOR SURFACE COLOR: very dark grayish-brown

WALL THICKNESS (IN MM): rim, $6.5 \mathrm{~mm}$

INTERIOR SURFACE TREATMENT: burnished

EXTERIOR SURFACE TREATMENT: burnished

HEIGHT (IN CM): 13.3

ORIFICE DIAMETER (IN CM): 15.0

DIAMETER AT BOTTOM OF RIM OR NECK (IN CM): 12.7

BASE DIAMETER (IN CM) AND SHAPE OF BASE: $8.2 \mathrm{~cm}$, circular and flat

ESTIMATED VOLUME (IN LITERS): 1.2

DECORATION (INCLUDING MOTIF AND

ELEMENTS WHEN APPARENT): Plain (Figure 27)

PIGMENT USE AND LOCATION ON VESSEL: none

TYPE AND VARIETY (IF KNOWN): Unidentified plain ware

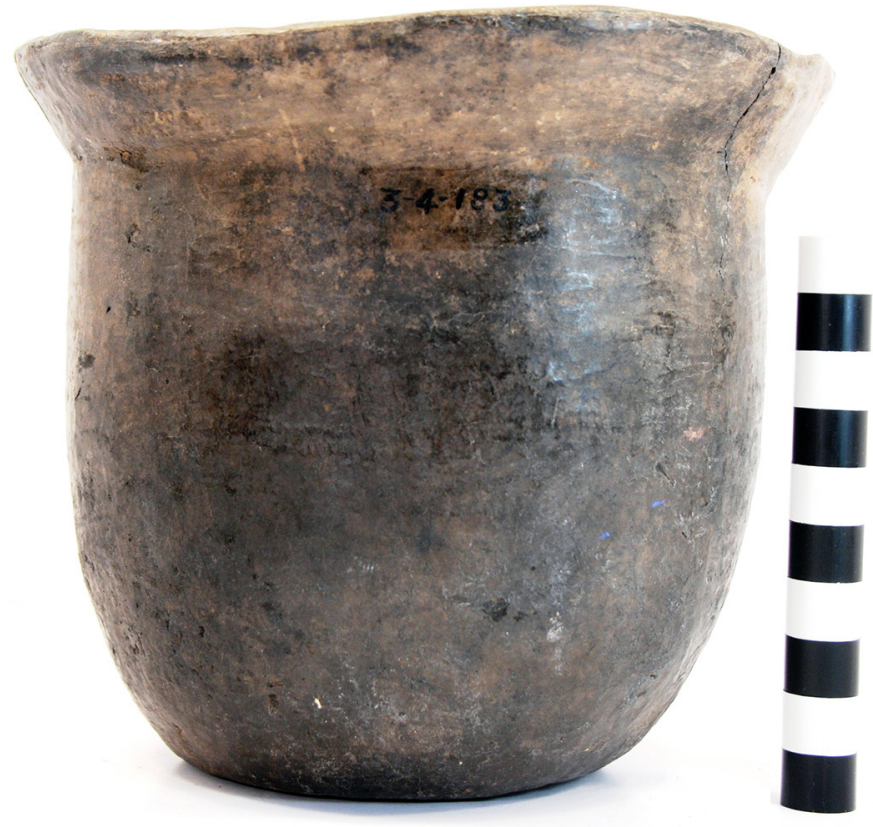

Figure 27. Plain jar, GTW-301. 
SITE NAME OR SITE NUMBER: George T. Wright Collection, Red River County, Texas

VESSEL NO.: GTW-305 [TX 094/1], B. R. R.

VESSEL FORM: Bowl (Figure 28)

NON-PLASTICS AND PASTE: grog

RIM AND LIP FORM: Direct rim with a rounded, exterior folded lip

CORE COLOR: $\mathrm{G}$ (fired in a reducing environment and cooled in the open air)

INTERIOR SURFACE COLOR: dark grayish-brown

EXTERIOR SURFACE COLOR: brown

WALL THICKNESS (IN MM): rim, $5.1 \mathrm{~mm}$

INTERIOR SURFACE TREATMENT: smoothed

EXTERIOR SURFACE TREATMENT: burnished

HEIGHT (IN CM): 9.0

ORIFICE DIAMETER (IN CM): 14.0

DIAMETER AT BOTTOM OF RIM OR NECK (IN CM): N/A

BASE DIAMETER (IN CM) AND SHAPE OF BASE: $6.0 \mathrm{~cm}$, circular and convex

ESTIMATED VOLUME (IN LITERS): 0.5

DECORATION (INCLUDING MOTIF AND ELEMENTS WHEN APPARENT): There are single horizontal trailed lines at the top and bottom of the vessel, along with four different sets of two vertical trailed scrolls with five trailed lines that end in hooked arm elements (Figure 28). The rim also has been lip notched from right to left.

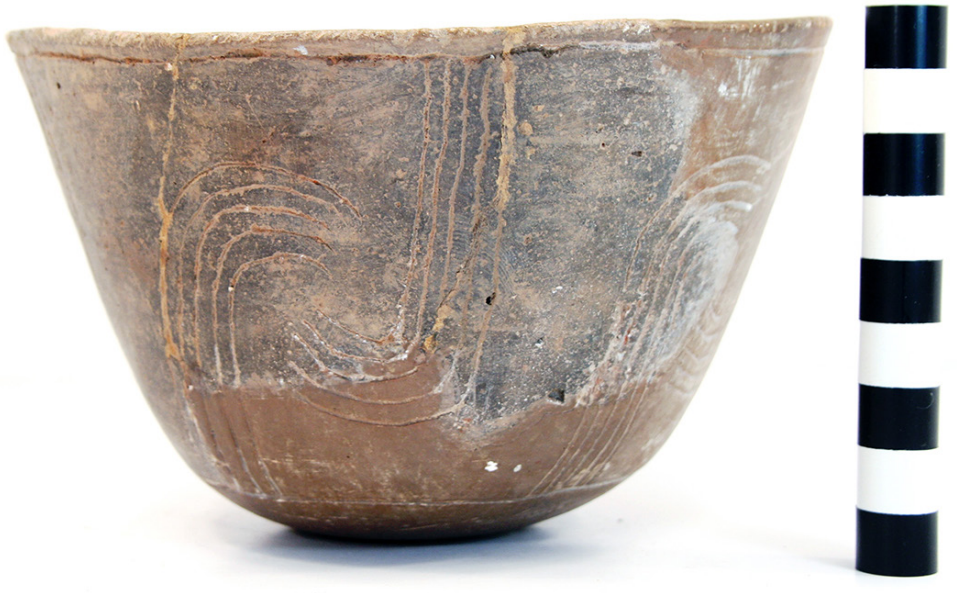

Figure 28. Keno Trailed, var. Phillips bowl, GTW-305.

PIGMENT USE AND LOCATION ON

VESSEL: none

TYPE AND VARIETY (IF KNOWN): Keno Trailed, var. Phillips (see Schambach and Miller 1984:123) 
SITE NAME OR SITE NUMBER: George T. Wright Collection, Red River County, Texas

VESSEL NO.: GTW-307 [TX 095/1], B. R. R.

VESSEL FORM: Jar with four rim peaks and for strap handles under the rim peaks (Figure 29)

NON-PLASTICS AND PASTE: shell

RIM AND LIP FORM: Everted rim and rounded lip

CORE COLOR: $\mathrm{H}$ (fired in a reducing environment and cooled in the open air)

INTERIOR SURFACE COLOR: reddish-brown

EXTERIOR SURFACE COLOR: dark grayish-brown; fire clouds on the body

WALL THICKNESS (IN MM): rim, $3.9 \mathrm{~mm}$

INTERIOR SURFACE TREATMENT: smoothed

EXTERIOR SURFACE TREATMENT: burnished on the body

HEIGHT (IN CM): 8.0

ORIFICE DIAMETER (IN CM): 9.8

DIAMETER AT BOTTOM OF RIM OR NECK

(IN CM): 8.0

BASE DIAMETER (IN CM) AND SHAPE OF BASE: $6.0 \mathrm{~cm}$, circular and convex

ESTIMATED VOLUME (IN LITERS): 0.5

DECORATION (INCLUDING MOTIF AND ELEMENTS WHEN APPARENT): The vessel rim has three horizontal rows of neck banding. The vessel body has four panels defined by vertical bracket elements. Each bracket is filled with an oval-shaped and semi-circular oval engraved element. Each panel has a large engraved circle with excised spurs, and there is an engraved diamond element at the center of the four circles (Figure 29).

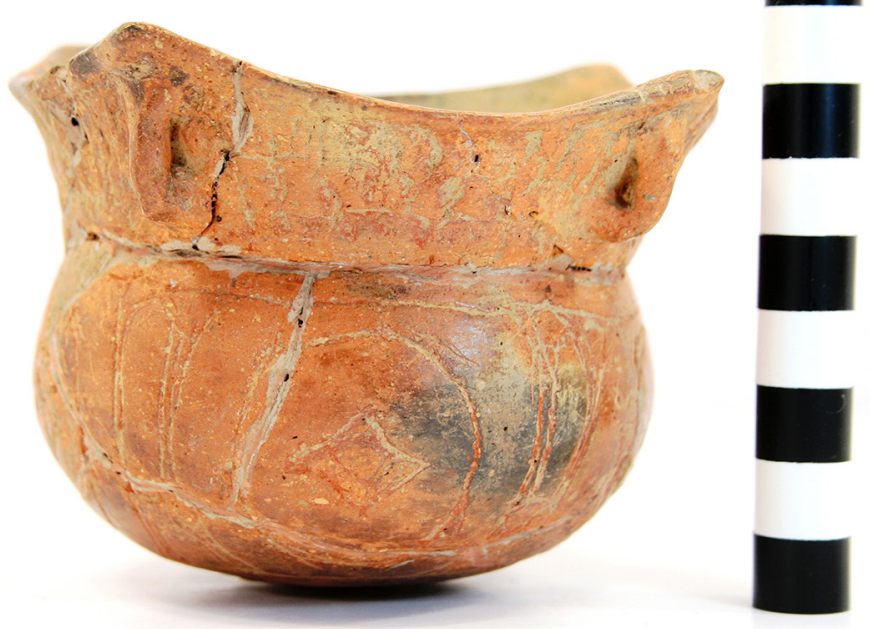

Figure 29. Nash Neck Banded-Avery Engraved jar with strap handles, GTW-307.

PIGMENT USE AND LOCATION ON VESSEL: red pigments in the engraved lines on the vessel body TYPE AND VARIETY (IF KNOWN): Nash Neck Banded-Avery Engraved 
SITE NAME OR SITE NUMBER: George T. Wright Collection, Red River County, Texas

VESSEL NO.: GTW-308 [TX 098/1], B. R. R.

VESSEL FORM: Bowl (Figure 30)

NON-PLASTICS AND PASTE: grog and bone

RIM AND LIP FORM: Everted rim and rounded lip

CORE COLOR: B (fired and cooled in a reducing environment)

INTERIOR SURFACE COLOR: black

EXTERIOR SURFACE COLOR: black; fire clouds on the rim and body

WALL THICKNESS (IN MM): rim, 4.5 mm

INTERIOR SURFACE TREATMENT: smoothed

EXTERIOR SURFACE TREATMENT: burnished

HEIGHT (IN CM): 8.0

ORIFICE DIAMETER (IN CM): 13.3

DIAMETER AT BOTTOM OF RIM OR NECK (IN CM): N/A

BASE DIAMETER (IN CM) AND SHAPE OF BASE: $6.8 \mathrm{~cm}$, circular and flat

ESTIMATED VOLUME (IN LITERS): 0.4

DECORATION (INCLUDING MOTIF AND ELEMENTS WHEN APPARENT):

The rim has four panels comprised of narrow horizontal and vertical zones filled with sets of negative ovals, engraved brackets, and excised spurs (Figure 30).

PIGMENT USE AND LOCATION ON VESSEL: none

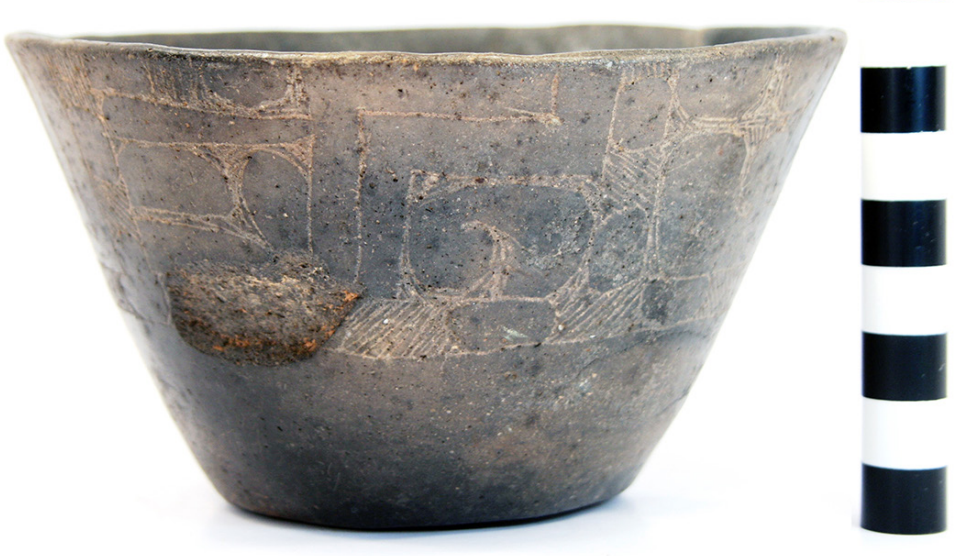

Figure 30. cf. Hodges Engraved bowl, GTW-308.

TYPE AND VARIETY (IF KNOWN): cf. Hodges Engraved (see Suhm and Jelks 1962:Plate 37o) 
SITE NAME OR SITE NUMBER: George T. Wright Collection, Red River County, Texas

VESSEL NO.: GTW-333 [TX 098/1], B. R. R. [duplicate number]

VESSEL FORM: Jar (Figure 31)

NON-PLASTICS AND PASTE: shell

RIM AND LIP FORM: Everted rim and rounded lip

CORE COLOR: B (fired and cooled in a reducing environment)

INTERIOR SURFACE COLOR: black

EXTERIOR SURFACE COLOR: black

WALL THICKNESS (IN MM): rim, $4.5 \mathrm{~mm}$

INTERIOR SURFACE TREATMENT: smoothed

EXTERIOR SURFACE TREATMENT: smoothed on the body

HEIGHT (IN CM): 10.5

ORIFICE DIAMETER (IN CM): 11.8

DIAMETER AT BOTTOM OF RIM OR NECK (IN CM): 8.8

BASE DIAMETER (IN CM) AND SHAPE OF BASE: $5.5 \mathrm{~cm}$, circular and flat

ESTIMATED VOLUME (IN LITERS): 0.7

DECORATION (INCLUDING MOTIF AND ELEMENTS WHEN APPARENT): The rim has three horizontal rows of tool punctations along with four equally-spaced appliqued nodes under the vessel lip. The vessel body has four sets of appliqued fillet chevrons; two chevrons have appliqued fillets that run from the right to the left and two that have appliqued fillets that run from the left to the right (Figure 31). The fillets extend to within $4.1 \mathrm{~cm}$ of the vessel base.

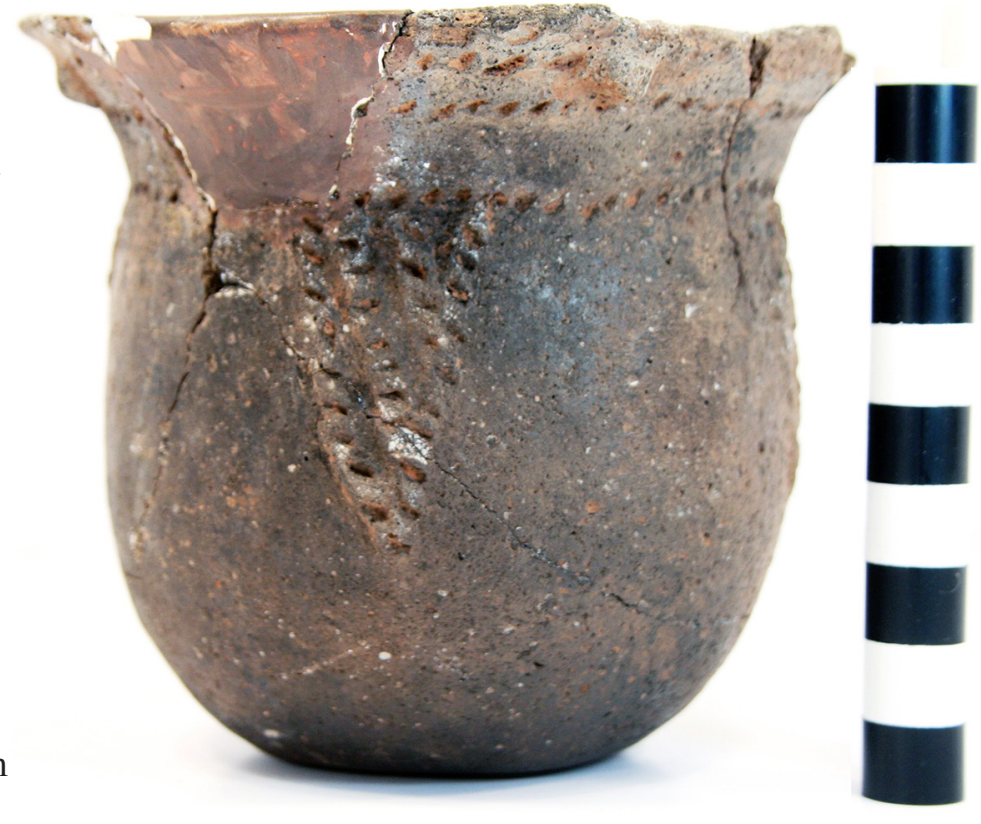

Figure 31. Emory Punctated-Incised jar, GTW-333.

PIGMENT USE AND LOCATION ON VESSEL: none

TYPE AND VARIETY (IF KNOWN): Emory Punctated-Incised 
SITE NAME OR SITE NUMBER: George T. Wright Collection, Red River County, Texas

VESSEL NO.: GTW-312 [TX 097/1], B. R. R.

VESSEL FORM: Jar (Figure 32)

NON-PLASTICS AND PASTE: shell

RIM AND LIP FORM: Everted rim and rounded lip

CORE COLOR: A (fired and cooled in an oxidizing environment)

INTERIOR SURFACE COLOR: yellowish-brown; fire clouds on the rim and body

EXTERIOR SURFACE COLOR: yellowish-brown; fire clouds on the rim and body

WALL THICKNESS (IN MM): rim, $3.8 \mathrm{~mm}$; body, $3.6 \mathrm{~mm}$

INTERIOR SURFACE TREATMENT: smoothed

EXTERIOR SURFACE TREATMENT: smoothed on the body

HEIGHT (IN CM): 7.5

ORIFICE DIAMETER (IN CM): 10.5

DIAMETER AT BOTTOM OF RIM OR NECK (IN CM): 9.0

BASE DIAMETER (IN CM) AND

SHAPE OF BASE: $4.3 \mathrm{~cm}$, circular and flat

ESTIMATED VOLUME (IN LITERS): 0.5

DECORATION (INCLUDING MOTIF AND ELEMENTS WHEN APPARENT):

The rim has one smoothed horizontal neck banded row (Figure 32).

PIGMENT USE AND LOCATION ON

VESSEL: none

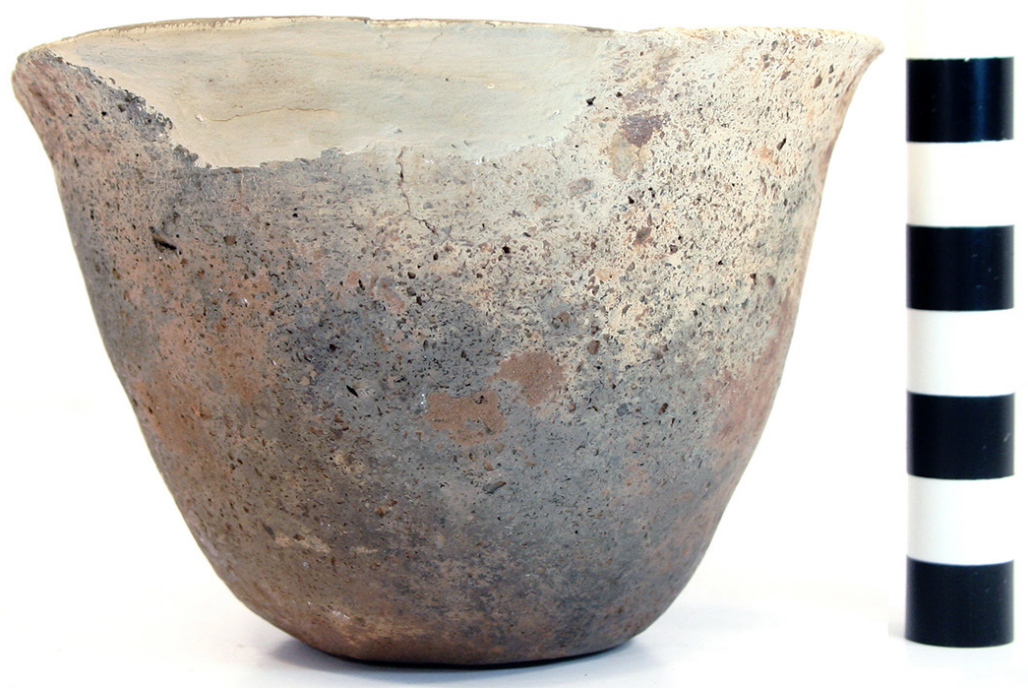

Figure 32. Nash Neck Banded jar, GTW-312.

TYPE AND VARIETY (IF KNOWN):

Nash Neck Banded 
SITE NAME OR SITE NUMBER: George T. Wright Collection, Red River County, Texas

VESSEL NO.: GTW-339 [TX 099/1], B. R. R.

VESSEL FORM: Jar (Figure 33)

NON-PLASTICS AND PASTE: shell

RIM AND LIP FORM: Everted rim and rounded lip

CORE COLOR: F (fired in a reducing environment and cooled in the open air)

INTERIOR SURFACE COLOR: reddish-brown; fire clouds on the rim and body

EXTERIOR SURFACE COLOR: reddish-brown; fire clouds on the rim and body

WALL THICKNESS (IN MM): rim, $3.8 \mathrm{~mm}$

INTERIOR SURFACE TREATMENT: none

EXTERIOR SURFACE TREATMENT: none

HEIGHT (IN CM): 6.8

ORIFICE DIAMETER (IN CM): 6.5

DIAMETER AT BOTTOM OF RIM OR NECK (IN

CM): 5.1

BASE DIAMETER (IN CM) AND SHAPE OF BASE:

$3.0 \mathrm{~cm}$, circular and convex

ESTIMATED VOLUME (IN LITERS): 0.3

DECORATION (INCLUDING MOTIF AND

ELEMENTS WHEN APPARENT): There are four appliqued nodes around the rim. The nodes extend from below the lip to halfway down the rim (Figure 33).

PIGMENT USE AND LOCATION ON VESSEL: none

TYPE AND VARIETY (IF KNOWN): cf. McKinney Plain (see Suhm and Jelks 1962:97)

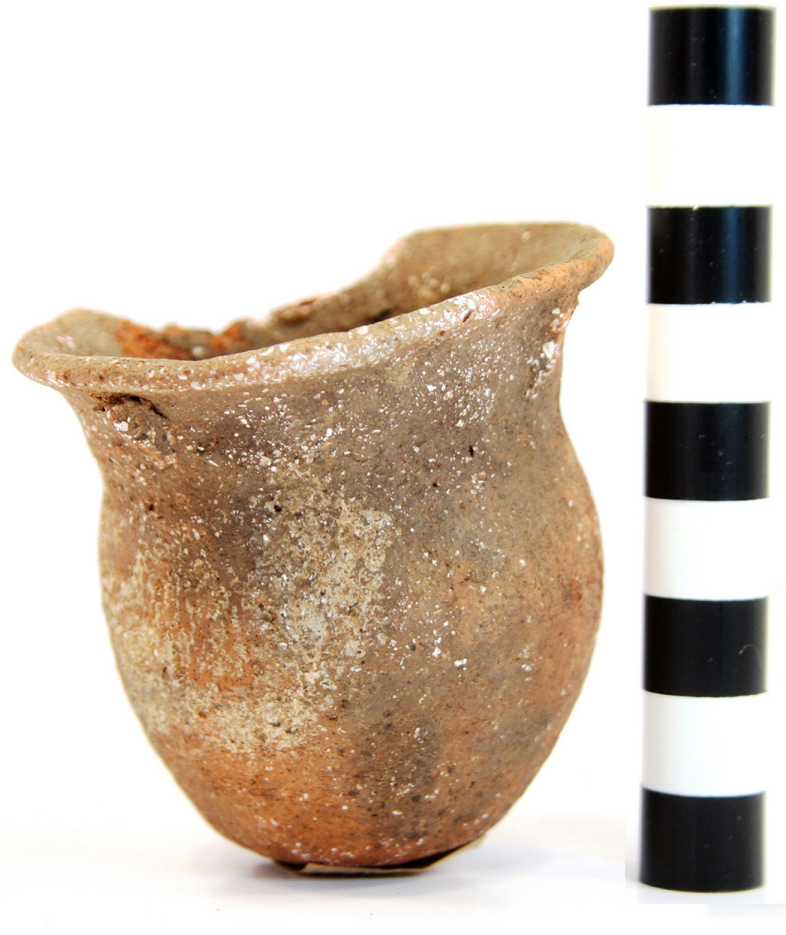

Figure 33. cf. McKinney Plain jar, GTW-339. 
SITE NAME OR SITE NUMBER: George T. Wright Collection, Red River County, Texas

VESSEL NO.: GTW-340 [TX 100/1], B. R. R.

VESSEL FORM: Jar (Figure 34); Wright's notebook indicates that animal bone fragments were found inside this vessel

NON-PLASTICS AND PASTE: shell

RIM AND LIP FORM: Everted rim and rounded lip

CORE COLOR: A (fired and cooled in an oxidizing environment)

INTERIOR SURFACE COLOR: yellowish-brown

EXTERIOR SURFACE COLOR: yellowish-brown; fire clouds on the rim and body

WALL THICKNESS (IN MM): rim, $5.3 \mathrm{~mm}$

INTERIOR SURFACE TREATMENT: none

EXTERIOR SURFACE TREATMENT: none

HEIGHT (IN CM): 7.4

ORIFICE DIAMETER (IN CM): 7.6

DIAMETER AT BOTTOM OF RIM OR NECK (IN CM): 6.2

BASE DIAMETER (IN CM) AND SHAPE OF BASE: $3.7 \mathrm{~cm}$, circular and flat

ESTIMATED VOLUME (IN LITERS): 0.3

DECORATION (INCLUDING MOTIF AND ELEMENTS WHEN APPARENT): The vessel rim has three horizontal neck banded rows as well as four vertical appliqued ridges. The vessel lip is notched. The vessel body is divided into five panels by single vertical incised lines. Each of the panels is filled with sets of diagonal opposed incised lines (Figure 34)

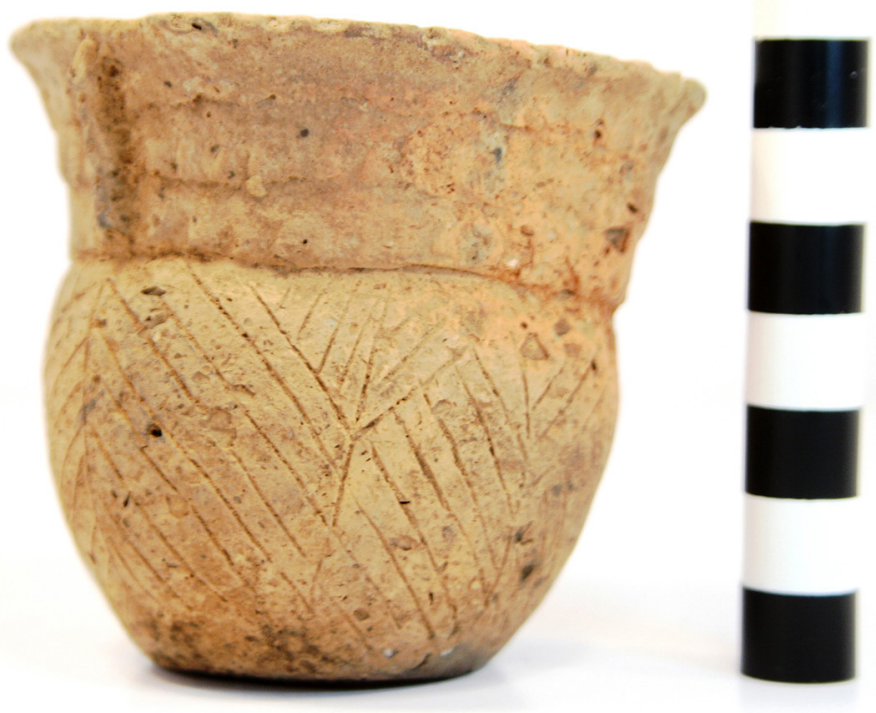

Figure 34. Nash Neck Banded jar, GTW-340.

PIGMENT USE AND LOCATION ON VESSEL: none

TYPE AND VARIETY (IF KNOWN): Nash Neck Banded 
SITE NAME OR SITE NUMBER: George T. Wright Collection, Red River County, Texas

VESSEL NO.: GTW-341 [TX 101/1], B. R. R.

VESSEL FORM: Miniature jar (Figure 35)

NON-PLASTICS AND PASTE: shell

RIM AND LIP FORM: Everted rim and rounded lip

CORE COLOR: B (fired and cooled in a reducing environment)

INTERIOR SURFACE COLOR: dark grayish-brown

EXTERIOR SURFACE COLOR: dark grayish-brown; fire clouds on the rim

WALL THICKNESS (IN MM): rim, $4.2 \mathrm{~mm}$

INTERIOR SURFACE TREATMENT: none

EXTERIOR SURFACE TREATMENT:

smoothed

HEIGHT (IN CM): 8.0

ORIFICE DIAMETER (IN CM): 8.9

DIAMETER AT BOTTOM OF RIM OR

NECK (IN CM): 6.6

BASE DIAMETER (IN CM) AND SHAPE

OF BASE: $4.2 \mathrm{~cm}$, circular and flat

ESTIMATED VOLUME (IN LITERS): 0.4

DECORATION (INCLUDING MOTIF AND

ELEMENTS WHEN APPARENT): Plain

(Figure 35)

PIGMENT USE AND LOCATION ON

VESSEL: none

TYPE AND VARIETY (IF KNOWN):

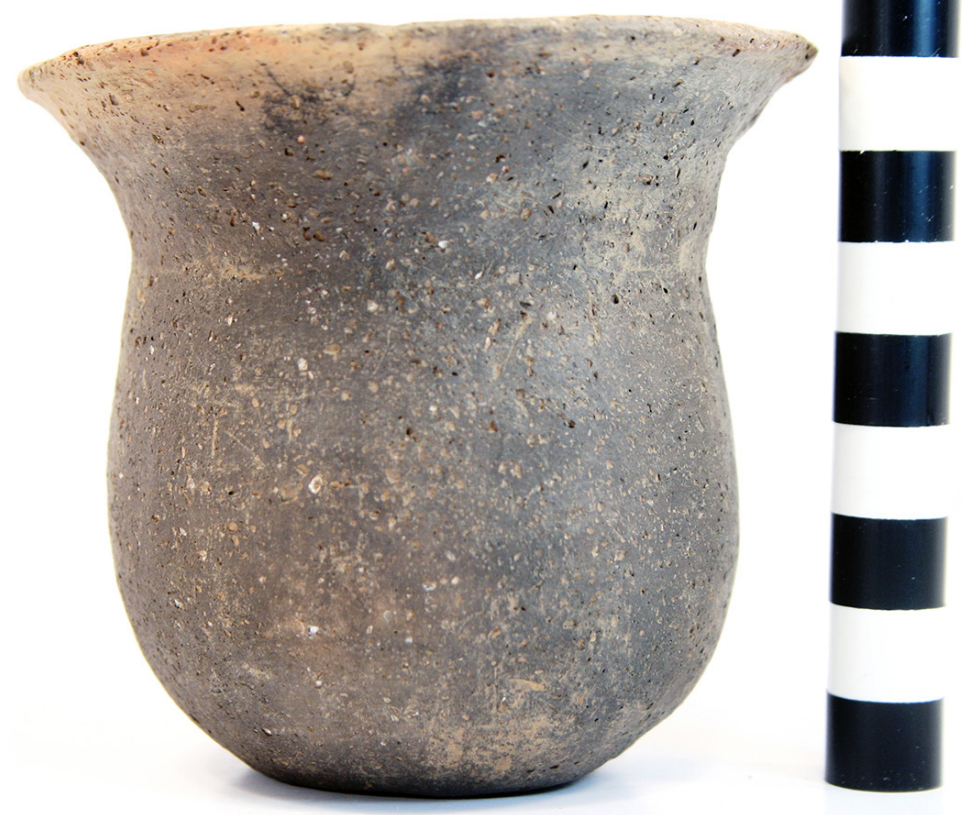

Figure 35. Plain jar, GTW-341.

Unidentified plain ware 
SITE NAME OR SITE NUMBER: George T. Wright Collection, Red River County, Texas

VESSEL NO.: GTW-342 [TX 102/1], B. R. R.

VESSEL FORM: Jar (Figure 36)

NON-PLASTICS AND PASTE: grog

RIM AND LIP FORM: Everted rim and rounded lip

CORE COLOR: F (fired in a reducing environment and cooled in the open air)

INTERIOR SURFACE COLOR: yellowish-brown; fire clouds on the rim

EXTERIOR SURFACE COLOR: yellowish-brown; fire clouds on the rim and body

WALL THICKNESS (IN MM): rim, 5.6 mm

INTERIOR SURFACE TREATMENT: smoothed

EXTERIOR SURFACE

TREATMENT: burnished

HEIGHT (IN CM): 6.9

ORIFICE DIAMETER (IN CM): 5.7

DIAMETER AT BOTTOM OF RIM

OR NECK (IN CM): 4.7

BASE DIAMETER (IN CM) AND SHAPE OF BASE: $3.5 \mathrm{~cm}$, circular and rounded

ESTIMATED VOLUME (IN

LITERS): 0.2

DECORATION (INCLUDING

MOTIF AND ELEMENTS WHEN

APPARENT): Plain (Figure 36)

PIGMENT USE AND LOCATION

ON VESSEL: none

TYPE AND VARIETY (IF KNOWN): Unidentified plain ware

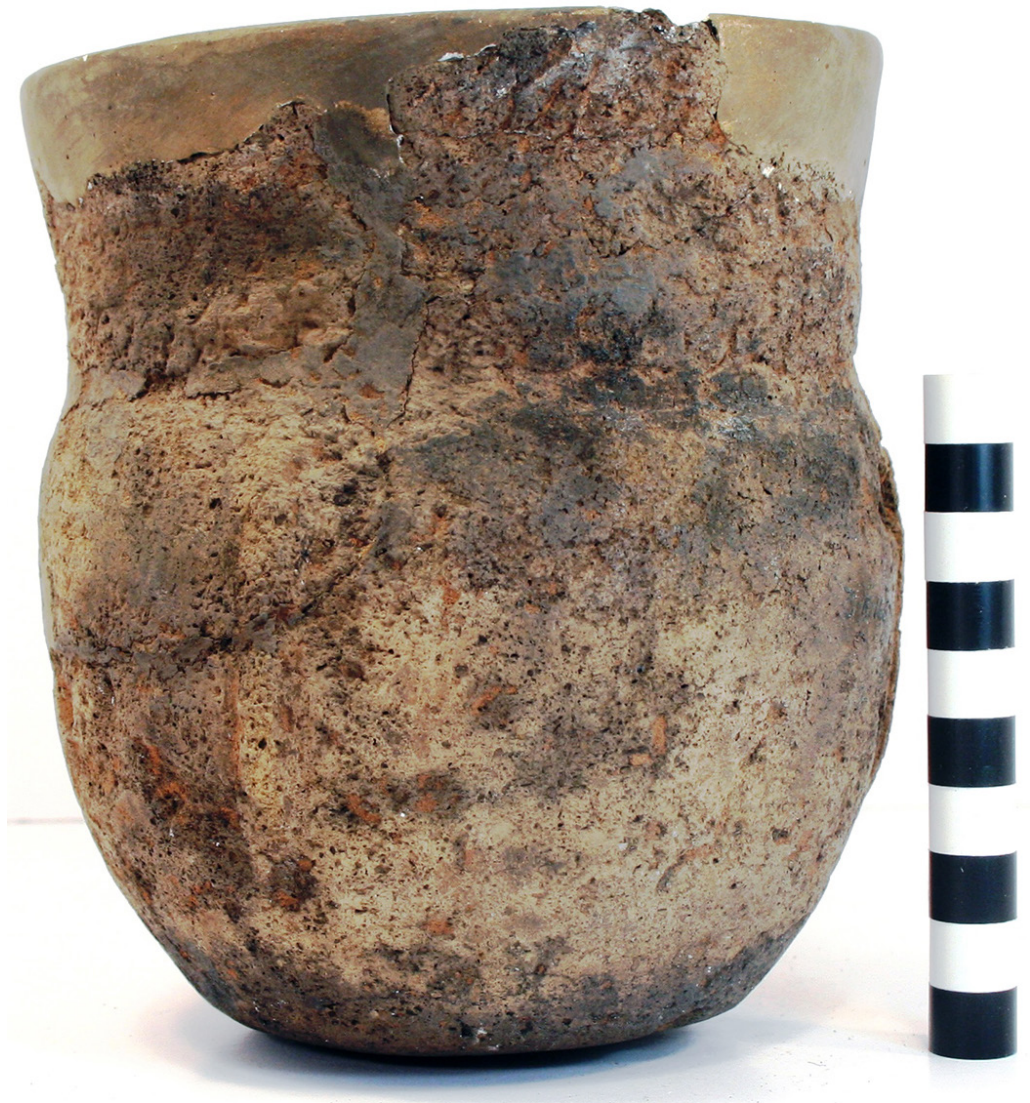

Figure 36. Plain jar, GTW-342. 
SITE NAME OR SITE NUMBER: George T. Wright Collection, Red River County, Texas. Wright's notebook indicates that this vessel was recovered from a small mound near Cuthand Creek, about 10 miles southwest of Clarksville, Texas. Cuthand Creek is a southeastward-flowing tributary to the Sulphur River.

VESSEL NO.: GTW-351 [TX 103/1], B. R. R.

VESSEL FORM: Jar (Figure 37)

NON-PLASTICS AND PASTE: shell

RIM AND LIP FORM: Everted rim and rounded lip

CORE COLOR: A (fired and cooled in an oxidizing environment)

INTERIOR SURFACE COLOR: yellowish-brown

EXTERIOR SURFACE COLOR: yellowish-brown; fire clouds on the rim and body

WALL THICKNESS (IN MM): rim, $6.0 \mathrm{~mm}$

INTERIOR SURFACE TREATMENT: none

EXTERIOR SURFACE TREATMENT: none

HEIGHT (IN CM): 10.7

ORIFICE DIAMETER (IN CM): 8.9

DIAMETER AT BOTTOM OF RIM OR NECK (IN CM): 8.2

BASE DIAMETER (IN CM) AND SHAPE OF BASE: $5.1 \mathrm{~cm}$, circular and flat

ESTIMATED VOLUME (IN LITERS): 0.6

DECORATION (INCLUDING MOTIF AND ELEMENTS WHEN APPARENT): The rim has five horizontal rows of tool punctations, and four vertical appliqued lugs under the vessel lip. The vessel body has four equally-spaced vertical appliqued fillets (Figure 37).

PIGMENT USE AND LOCATION ON VESSEL: none

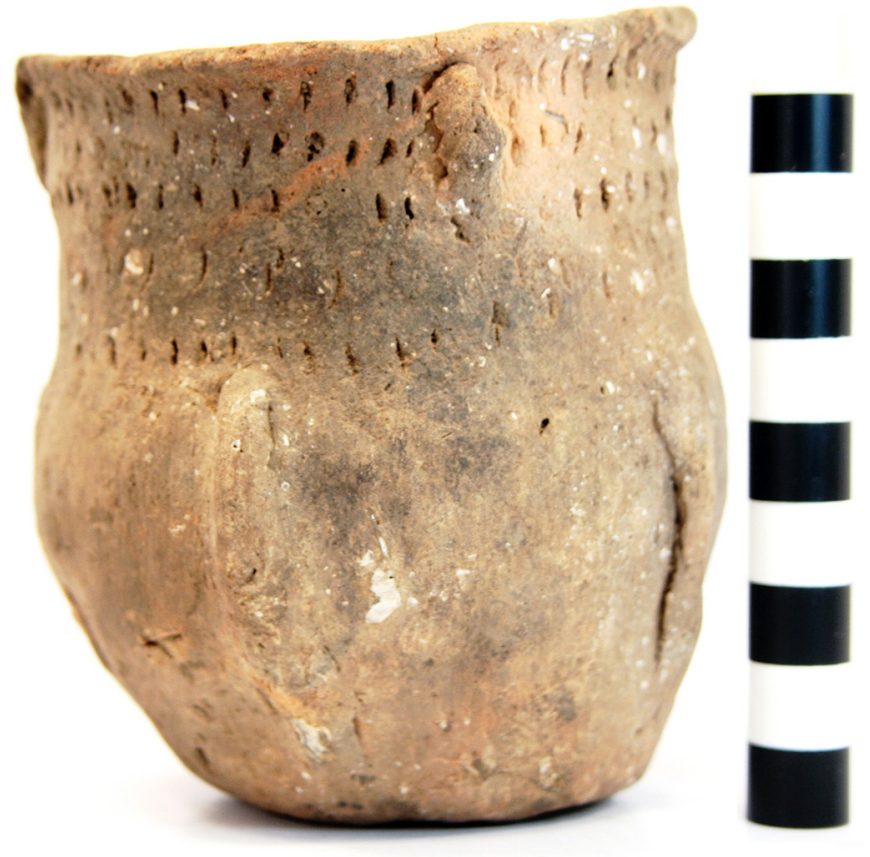

Figure 37. Emory Punctated-Incised jar, GTW-351.

TYPE AND VARIETY (IF KNOWN): Emory Punctated-Incised 
SITE NAME OR SITE NUMBER: George T. Wright Collection, Red River County, Texas. Wright's notebook indicates that this vessel came from a site on Cuthand Creek, about 8 miles southwest of Clarksville, Texas.

VESSEL NO.: GTW-382 [TX 104/1], B. R. R.

VESSEL FORM: Jar with four rim peaks (Figure 38)

NON-PLASTICS AND PASTE: grog

RIM AND LIP FORM: Everted rim and rounded lip

CORE COLOR: F (fired in a reducing environment and cooled in the open air)

INTERIOR SURFACE COLOR: yellowish-brown; fire clouds on the rim; organic residue on the rim

EXTERIOR SURFACE COLOR: yellowish-brown; fire clouds on the rim and body

WALL THICKNESS (IN MM): rim, $5.1 \mathrm{~mm}$

INTERIOR SURFACE TREATMENT: smoothed

EXTERIOR SURFACE TREATMENT: none

HEIGHT (IN CM): 10.8

ORIFICE DIAMETER (IN CM): 11.5

DIAMETER AT BOTTOM OF RIM OR NECK (IN CM): 8.5

BASE DIAMETER (IN CM) AND SHAPE OF BASE: $5.7 \mathrm{~cm}$, circular and flat

ESTIMATED VOLUME (IN LITERS): 0.8

DECORATION (INCLUDING MOTIF AND ELEMENTS WHEN APPARENT): The rim has two horizontal rows of tool punctations and four sets of bracket-shaped appliqued lugs under the lip and rim peaks. The vessel body has four sets of chevron-shaped appliqued ridges between four sets of vertical appliqued ridges (Figure 38)

PIGMENT USE AND LOCATION ON VESSEL: none

TYPE AND VARIETY (IF KNOWN): Emory Punctated-Incised

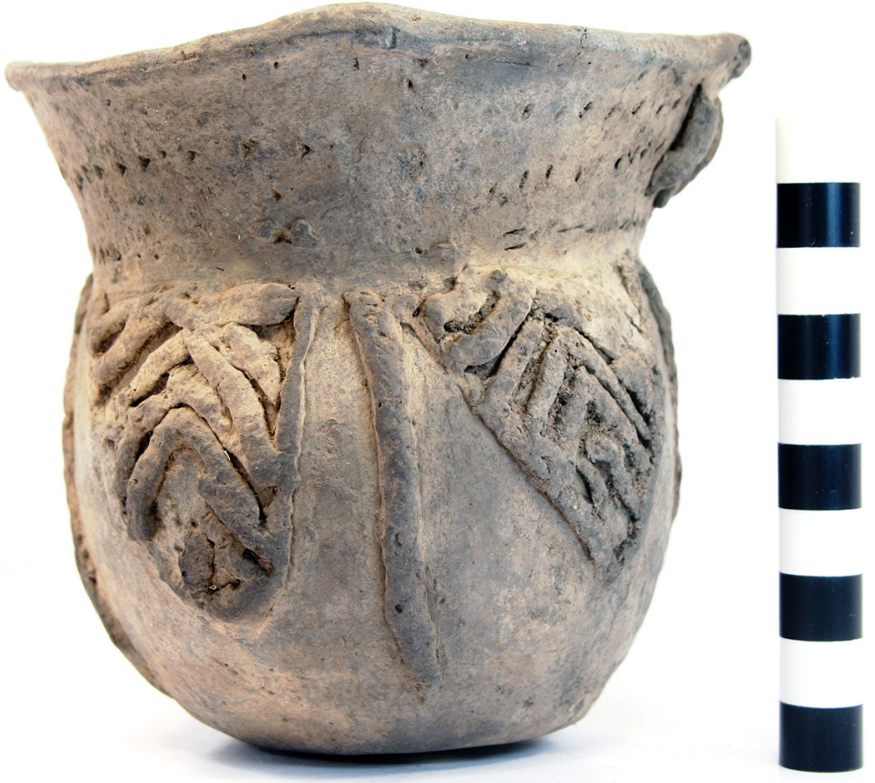

Figure 38. Emory Punctated-Incised jar with rim peaks, GTW-382. 
SITE NAME OR SITE NUMBER: George T. Wright Collection, Red River County, Texas

VESSEL NO.: GTW-385, B. R. R.

VESSEL FORM: Jar (Figure 39)

NON-PLASTICS AND PASTE: shell

RIM AND LIP FORM: Everted rim and rounded lip

CORE COLOR: $\mathrm{G}$ (fired in a reducing environment and cooled in the open air)

INTERIOR SURFACE COLOR: very dark grayish-brown; organic residue on the rim and body

EXTERIOR SURFACE COLOR: yellowish-brown; fire clouds on the rim, body, and base; organic residue on the rim and body

WALL THICKNESS (IN MM): rim, 4.9 mm

INTERIOR SURFACE TREATMENT: none

EXTERIOR SURFACE TREATMENT: smoothed on lower body

HEIGHT (IN CM): 13.9

ORIFICE DIAMETER (IN CM): 11.5

DIAMETER AT BOTTOM OF RIM OR NECK (IN CM): 9.6

BASE DIAMETER (IN CM) AND SHAPE OF BASE: $7.6 \mathrm{~cm}$, circular and flat

\section{ESTIMATED VOLUME (IN LITERS): 0.9}

DECORATION (INCLUDING MOTIF AND ELEMENTS WHEN APPARENT): The rim has four equally-spaced appliqued nodes under the vessel lip. The vessel body has four sets of appliqued ridge triangles; there are two appliqued nodes within each triangle. Between the appliqued ridge triangles are four sets of two appliqued nodes aligned vertically under the nodes on the rim. Between these nodes are two rows of horizontal tool punctations (Figure 39).

PIGMENT USE AND LOCATION ON VESSEL: none

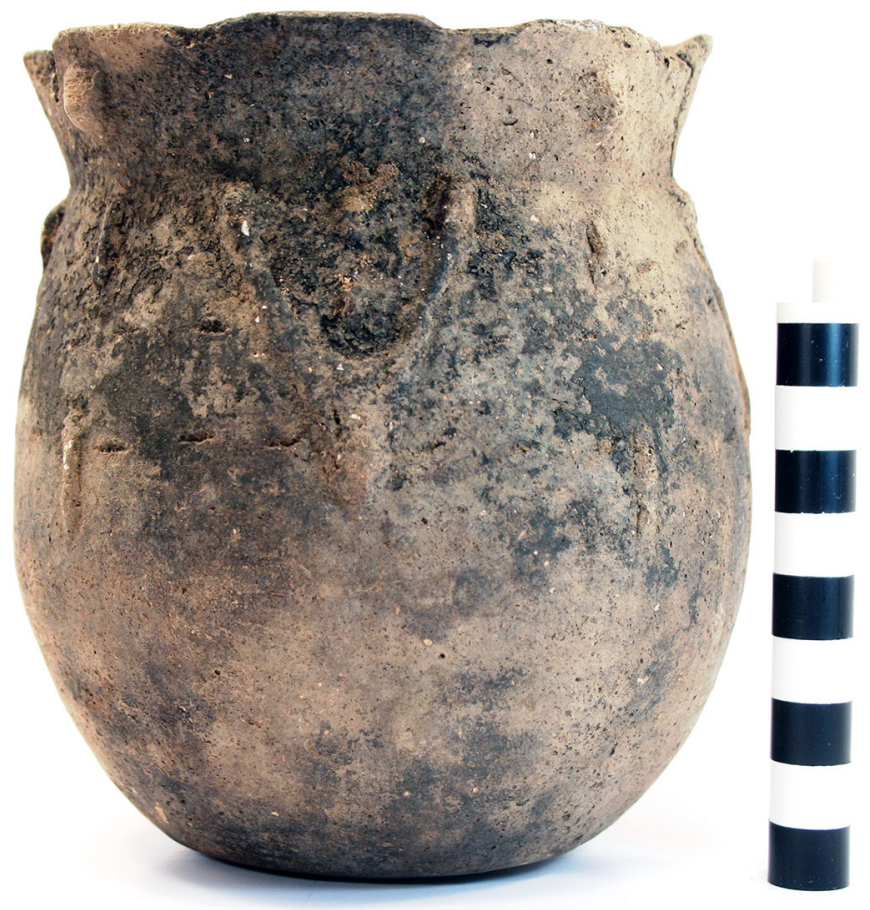

Figure 39. cf. McKinney Plain jar, GTW-385.

TYPE AND VARIETY (IF KNOWN): cf. McKinney Plain 
SITE NAME OR SITE NUMBER: George T. Wright Collection, Red River County, Texas

VESSEL NO.: GTW-387 [TX 106/1], B. R. R.

VESSEL FORM: Jar

NON-PLASTICS AND PASTE: shell

RIM AND LIP FORM: Direct rim and rounded lip

CORE COLOR: F (fired in a reducing environment and cooled in the open air)

INTERIOR SURFACE COLOR: yellowish-brown; fire clouds on the body

EXTERIOR SURFACE COLOR: yellowish-brown; fire clouds on the rim and body

WALL THICKNESS (IN MM): rim, $5.1 \mathrm{~mm}$

INTERIOR SURFACE TREATMENT: none

EXTERIOR SURFACE TREATMENT: none

HEIGHT (IN CM): 14.6

ORIFICE DIAMETER (IN CM): 12.8

DIAMETER AT BOTTOM OF RIM OR NECK (IN CM): 14.2

BASE DIAMETER (IN CM) AND SHAPE OF BASE: $7.6 \mathrm{~cm}$, circular and flat ESTIMATED VOLUME (IN LITERS): 1.1

DECORATION (INCLUDING MOTIF AND ELEMENTS WHEN APPARENT): The vessel body has four equally-spaced vertical appliqued ridges; the rim is plain (and eroded).

PIGMENT USE AND LOCATION ON VESSEL: none

TYPE AND VARIETY (IF KNOWN): cf. McKinney Plain 
SITE NAME OR SITE NUMBER: George T. Wright Collection, Red River County, Texas. Wright's notebook indicates this vessel came from a site on Cuthand Creek.

VESSEL NO.: GTW-392 [TX 108/1], B. R. R.

VESSEL FORM: Jar (Figure 40)

NON-PLASTICS AND PASTE: grog

RIM AND LIP FORM: Everted rim and rounded lip

CORE COLOR: $\mathrm{G}$ (fired in a reducing environment and cooled in the open air)

INTERIOR SURFACE COLOR: very dark grayish-brown

EXTERIOR SURFACE COLOR: dark yellowish-brown; fire clouds on the rim, body, and base

WALL THICKNESS (IN MM): rim, $6.9 \mathrm{~mm}$

INTERIOR SURFACE TREATMENT: none

EXTERIOR SURFACE TREATMENT: smoothed

HEIGHT (IN CM): 15.9

ORIFICE DIAMETER (IN CM): 12.8

DIAMETER AT BOTTOM OF RIM OR NECK (IN CM): 9.9

BASE DIAMETER (IN CM) AND SHAPE OF BASE: $6.4 \mathrm{~cm}$, circular and flat

ESTIMATED VOLUME (IN LITERS): 1.2

DECORATION (INCLUDING MOTIF AND ELEMENTS WHEN APPARENT): The vessel rim has four equally-spaced appliqued nodes at mid-rim. Beneath these appliqued nodes on the vessel body are four appliqued nodes and four lower vertical appliqued ridges (Figure 40). The appliqued ridges extend to within $5.7 \mathrm{~cm}$ of the vessel base.

PIGMENT USE AND LOCATION ON VESSEL: none

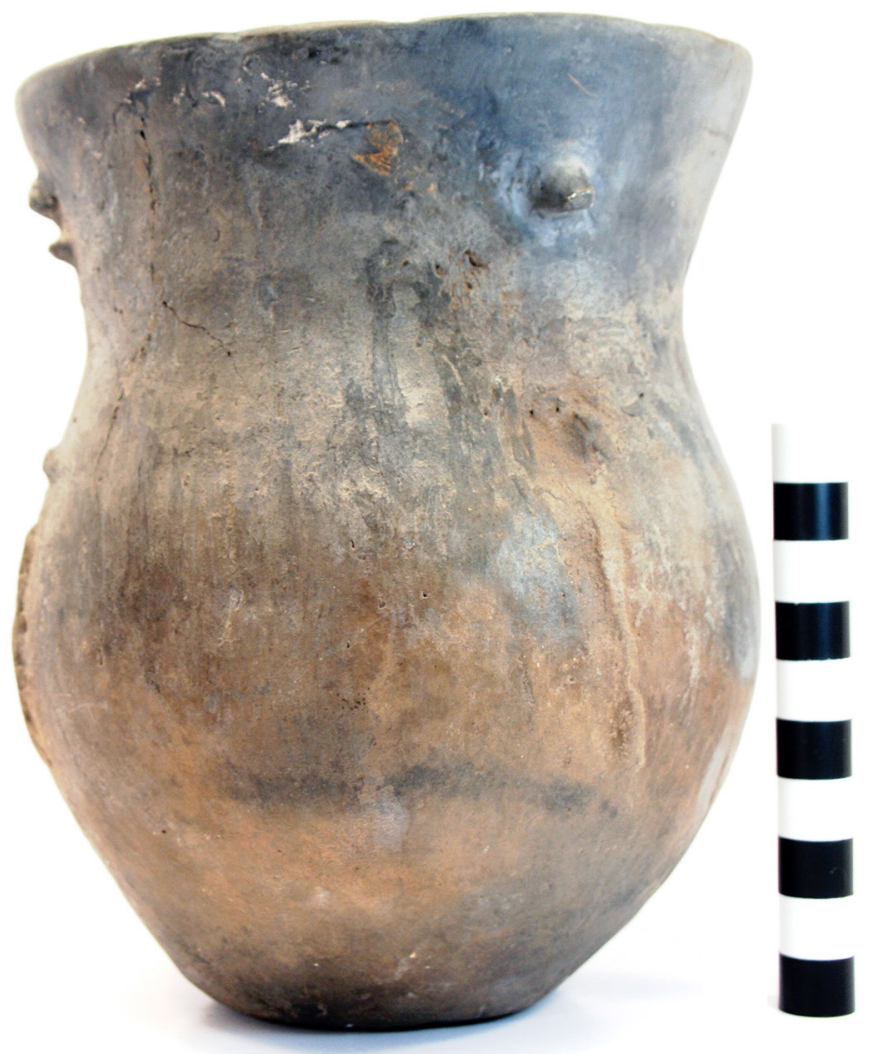

Figure 40. cf. McKinney Plain jar, GTW-392.

TYPE AND VARIETY (IF KNOWN): cf. McKinney Plain 
SITE NAME OR SITE NUMBER: George T. Wright Collection, Red River County, Texas. Wright's notebook indicates that this vessel came from a mound site on Cuthand Creek, presumably the same mound mentioned for GTW-351 on Cuthand Creek about 10 miles southwest of Clarksville, Texas.

VESSEL NO.: GTW-397 [TX 109/1], B. R. R.

VESSEL FORM: Jar (Figure 41)

NON-PLASTICS AND PASTE: shell

RIM AND LIP FORM: Everted rim and rounded lip

CORE COLOR: F (fired in a reducing environment and cooled in the open air)

INTERIOR SURFACE COLOR: yellowish-brown; fire clouds on the rim

EXTERIOR SURFACE COLOR: yellowish-brown; fire clouds on the rim, body, and base

WALL THICKNESS (IN MM): rim, $5.1 \mathrm{~mm}$

INTERIOR SURFACE TREATMENT: none

EXTERIOR SURFACE TREATMENT: smoothed on the body

HEIGHT (IN CM): 16.7

ORIFICE DIAMETER (IN CM): 12.4

DIAMETER AT BOTTOM OF RIM OR NECK (IN CM): 10.2

BASE DIAMETER (IN CM) AND SHAPE OF

BASE: $8.9 \mathrm{~cm}$, circular and flat

ESTIMATED VOLUME (IN LITERS): 1.2

DECORATION (INCLUDING MOTIF AND

ELEMENTS WHEN APPARENT): The rim has 10

horizontal neck banded rows, and each row has been tool punctated. Also on the rim are four bracketshaped appliqued lugs under the vessel lip. The vessel body has four chevron-shaped appliqued fillet elements filled with diagonal opposed appliqued fillets (Figure 41).

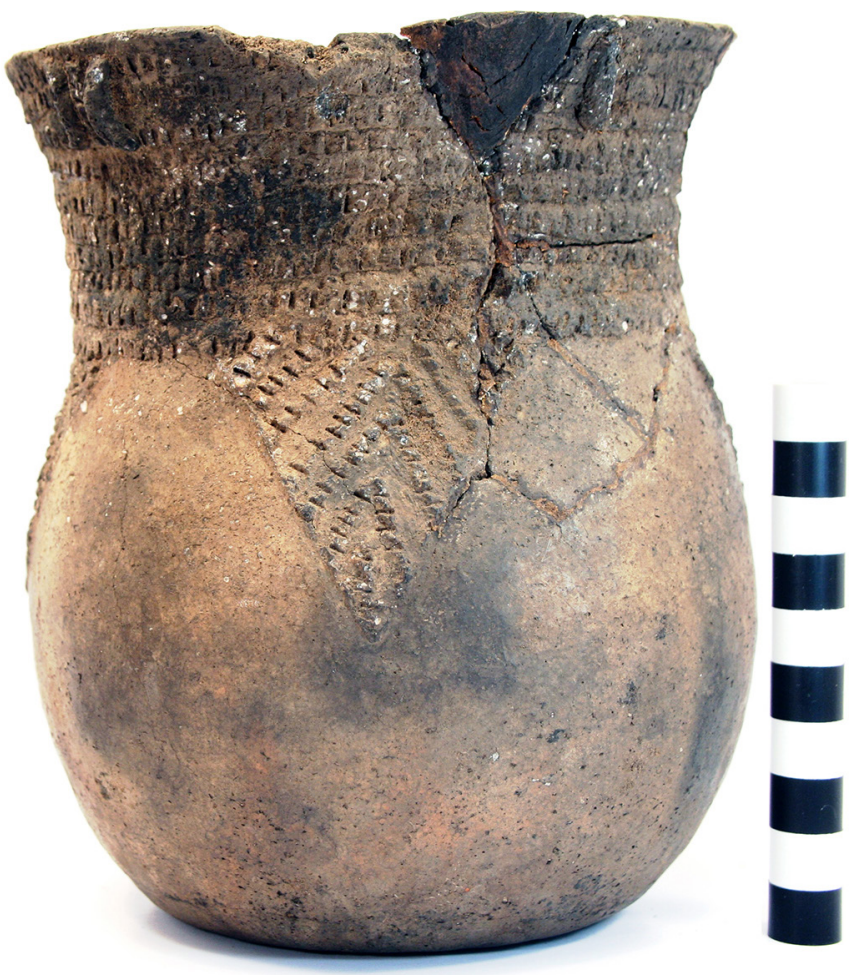

Figure 41. Nash Neck Banded jar, GTW-397.

PIGMENT USE AND LOCATION ON VESSEL: none

TYPE AND VARIETY (IF KNOWN): Nash Neck Banded 
SITE NAME OR SITE NUMBER: George T. Wright Collection, Red River County, Texas

VESSEL NO.: GTW-403 [TX 110/1], B. R. R.

VESSEL FORM: Jar with four rim peaks (Figure 42)

NON-PLASTICS AND PASTE: shell

RIM AND LIP FORM: Everted rim and rounded, exterior folded lip

CORE COLOR: F (fired in a reducing environment and cooled in the open air)

INTERIOR SURFACE COLOR: light grayish-brown

EXTERIOR SURFACE COLOR: light grayish-brown with organic residue on the rim and body

WALL THICKNESS (IN MM): rim, $5.1 \mathrm{~mm}$

INTERIOR SURFACE TREATMENT: smoothed

EXTERIOR SURFACE TREATMENT: smoothed on the body

HEIGHT (IN CM): 14.8

ORIFICE DIAMETER (IN CM): 14.0

DIAMETER AT BOTTOM OF RIM OR NECK (IN CM): 11.3

BASE DIAMETER (IN CM) AND SHAPE OF BASE: $5.7 \mathrm{~cm}$, circular and rounded

ESTIMATED VOLUME (IN LITERS): 1.2

DECORATION (INCLUDING MOTIF AND ELEMENTS WHEN APPARENT): The rim has three horizontal neck banded rows and four appliqued nodes under the rim peaks. The vessel body has four appliqued nodes on the upper body, placed below the appliqued nodes on the rim (Figure 42).

PIGMENT USE AND LOCATION ON VESSEL: none

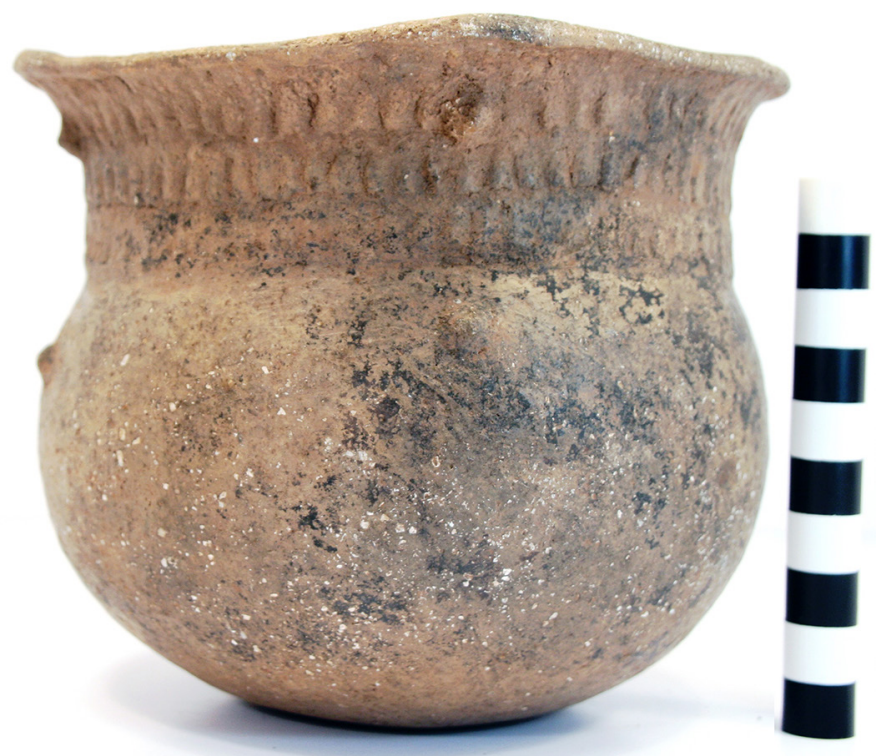

Figure 42. Nash Neck Banded jar, GTW-403.

TYPE AND VARIETY (IF KNOWN): Nash Neck Banded 
SITE NAME OR SITE NUMBER: George T. Wright Collection, Red River County, Texas

VESSEL NO.: GTW-408b [TX 235/1], B. R. R.

VESSEL FORM: Jar (Figure 43)

NON-PLASTICS AND PASTE: shell

RIM AND LIP FORM: Everted rim and rounded lip

CORE COLOR: $\mathrm{G}$ (fired in a reducing environment and cooled in the open air)

INTERIOR SURFACE COLOR: dark grayish-brown

EXTERIOR SURFACE COLOR: yellowish-brown; fire clouds on the body

WALL THICKNESS (IN MM): rim, 4.6 mm

INTERIOR SURFACE TREATMENT: smoothed

EXTERIOR SURFACE TREATMENT: smoothed on the body

HEIGHT (IN CM): 13.5

ORIFICE DIAMETER (IN CM): 20.0

DIAMETER AT BOTTOM OF RIM OR NECK (IN CM): 16.5

BASE DIAMETER (IN CM) AND SHAPE OF BASE: $7.0 \mathrm{~cm}$, circular and flat

ESTIMATED VOLUME (IN LITERS): 1.6

DECORATION (INCLUDING MOTIF AND ELEMENTS WHEN APPARENT): The rim has two rows of linear tool punctations, and a collar at the rim-body juncture. There are also four appliqued nodes on the vessel lip. The vessel body has four equally-spaced vertical appliqued fillets (Figure 43).

PIGMENT USE AND LOCATION ON VESSEL:

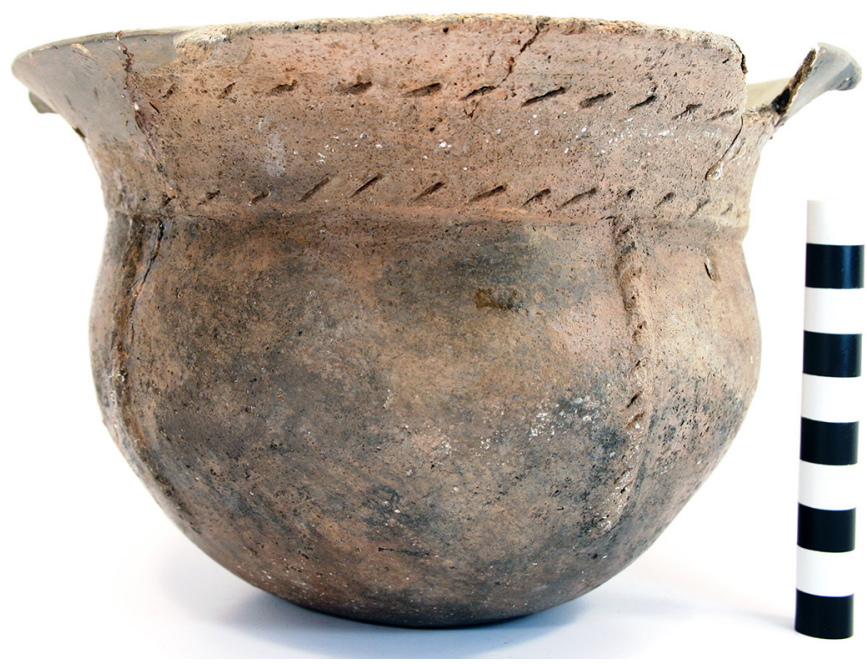

Figure 43. Emory Punctated-Incised jar, GTW-408b. none

TYPE AND VARIETY (IF KNOWN): Emory

Punctated-Incised 
SITE NAME OR SITE NUMBER: George T. Wright Collection, Red River County, Texas

VESSEL NO.: GTW-412 [TX 111/1], B. R. R.

VESSEL FORM: Jar (Figure 44)

NON-PLASTICS AND PASTE: shell

RIM AND LIP FORM: Everted rim and rounded lip

CORE COLOR: B (fired and cooled in a reducing environment)

INTERIOR SURFACE COLOR: very dark grayish-brown

EXTERIOR SURFACE COLOR: dark grayish-brown

WALL THICKNESS (IN MM): rim, $5.1 \mathrm{~mm}$

INTERIOR SURFACE TREATMENT: smoothed

EXTERIOR SURFACE TREATMENT:

smoothed

HEIGHT (IN CM): 20.9

ORIFICE DIAMETER (IN CM): 17.1

DIAMETER AT BOTTOM OF RIM OR NECK

(IN CM): 15.6

BASE DIAMETER (IN CM) AND SHAPE OF

BASE: $8.5 \mathrm{~cm}$, circular and flat

ESTIMATED VOLUME (IN LITERS): 3.2

DECORATION (INCLUDING MOTIF AND ELEMENTS WHEN APPARENT): The vessel rim has five horizontal rows of neck bands and four equally-spaced bracket-shaped appliqued lugs below the vessel lip. The vessel body has four vertical appliqued fillets that are centered below the lugs (Figure 44).

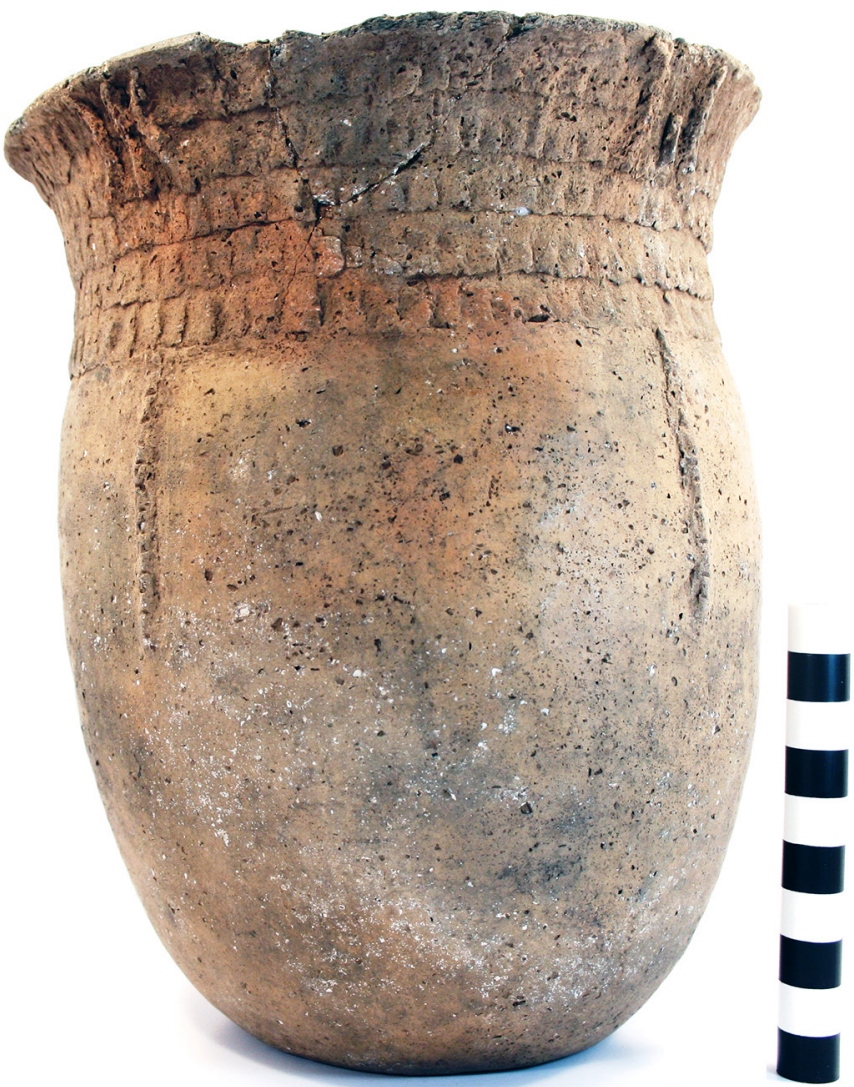

Figure 44. Nash Neck Banded jar, GTW-412.

PIGMENT USE AND LOCATION ON VESSEL: none

TYPE AND VARIETY (IF KNOWN): Nash Neck Banded 
SITE NAME OR SITE NUMBER: George T. Wright Collection, Red River County, Texas

VESSEL NO.: GTW-413 [TX 112/1], B. R. R.

VESSEL FORM: Jar

NON-PLASTICS AND PASTE: shell

RIM AND LIP FORM: Everted rim and rounded lip

CORE COLOR: F (fired in a reducing environment and cooled in the open air)

INTERIOR SURFACE COLOR: yellowish-brown

EXTERIOR SURFACE COLOR: yellowish-brown; fire clouds on the rim and body; organic residue on the body

WALL THICKNESS (IN MM): rim, $8.3 \mathrm{~mm}$; body, $6.2 \mathrm{~mm}$; base, $8.1 \mathrm{~mm}$

INTERIOR SURFACE TREATMENT: smoothed

EXTERIOR SURFACE TREATMENT: smoothed on the body

HEIGHT (IN CM): N/A

ORIFICE DIAMETER (IN CM): 23.0

DIAMETER AT BOTTOM OF RIM OR NECK (IN CM): 21.0

BASE DIAMETER (IN CM) AND SHAPE OF BASE: $8.2 \mathrm{~cm}$, circular and flat

ESTIMATED VOLUME (IN LITERS): N/A

DECORATION (INCLUDING MOTIF AND ELEMENTS WHEN APPARENT): The rim of the vessel has four horizontal neck banded rows and four equally-spaced appliqued nodes under the vessel lip.

PIGMENT USE AND LOCATION ON VESSEL: none

TYPE AND VARIETY (IF KNOWN): Nash Neck Banded 
SITE NAME OR SITE NUMBER: George T. Wright Collection, Red River County, Texas

VESSEL NO.: GTW-414 [TX 113/1], B. R. R.

VESSEL FORM: Jar (Figure 45)

NON-PLASTICS AND PASTE: grog

RIM AND LIP FORM: Everted rim and rounded lip

CORE COLOR: G (fired in a reducing environment and cooled in the open air)

INTERIOR SURFACE COLOR: black

EXTERIOR SURFACE COLOR: yellowish-brown; fire clouds on the rim, body, and base; organic residue on the rim and upper body

WALL THICKNESS (IN MM): rim, 6.4 mm

INTERIOR SURFACE TREATMENT: smoothed

EXTERIOR SURFACE TREATMENT: smoothed on the body

HEIGHT (IN CM): 20.5

ORIFICE DIAMETER (IN CM): 15.7

DIAMETER AT BOTTOM OF RIM OR NECK (IN CM): 13.5

BASE DIAMETER (IN CM) AND SHAPE OF BASE: $7.5 \mathrm{~cm}$, circular and flat

ESTIMATED VOLUME (IN LITERS): 2.9

DECORATION (INCLUDING MOTIF AND ELEMENTS WHEN APPARENT): The vessel rim has two smoothed over horizontal rows of neck bands as well as four equally-spaced appliqued nodes at mid-rim. The vessel body has four sets of chevronshaped appliqued ridges (Figure 45). The chevrons extend to within $14.0 \mathrm{~cm}$ of the vessel base.

PIGMENT USE AND LOCATION ON VESSEL: none

TYPE AND VARIETY (IF KNOWN): Nash Neck Banded

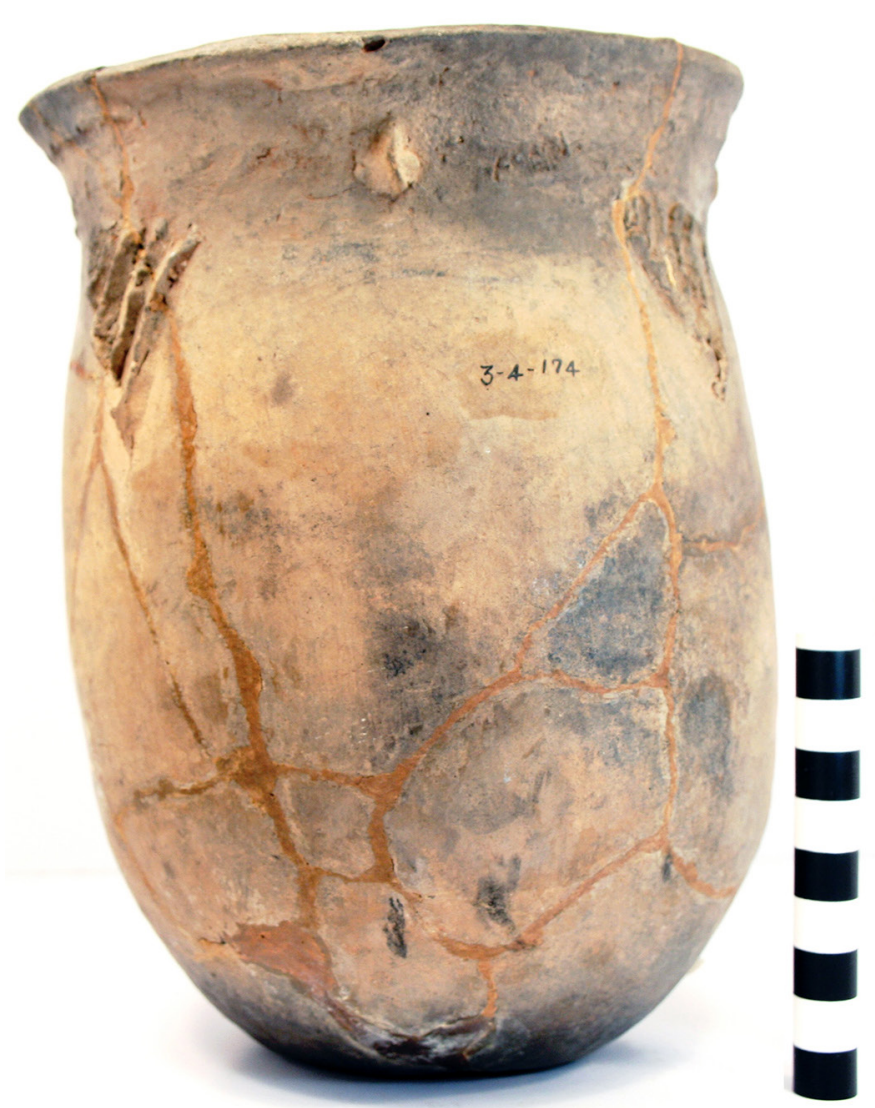

Figure 45. Nash Neck Banded jar, GTW-414. 
SITE NAME OR SITE NUMBER: George T. Wright Collection, Red River County, Texas

VESSEL NO.: GTW-416 [TX 114/1], B. R. R.

VESSEL FORM: Jar (Figure 46)

NON-PLASTICS AND PASTE: shell

RIM AND LIP FORM: Direct rim and rounded lip

CORE COLOR: G (fired in a reducing environment and cooled in the open air)

INTERIOR SURFACE COLOR: dark grayish-brown; fire clouds on the rim and body

EXTERIOR SURFACE COLOR: yellowish-brown; fire clouds on the rum and body

WALL THICKNESS (IN MM): rim, $4.9 \mathrm{~mm}$; body, $5.2 \mathrm{~mm}$

INTERIOR SURFACE TREATMENT: smoothed

EXTERIOR SURFACE TREATMENT: smoothed on the body

HEIGHT (IN CM): 17.5

ORIFICE DIAMETER (IN CM): 15.0

DIAMETER AT BOTTOM OF RIM OR NECK (IN CM): 14.7

BASE DIAMETER (IN CM) AND SHAPE OF BASE: $8.5 \mathrm{~cm}$, circular and flat

ESTIMATED VOLUME (IN LITERS): 2.4

DECORATION (INCLUDING MOTIF AND ELEMENTS WHEN APPARENT): The rim has six horizontal rows of tool punctations as well as four bracket-shaped appliqued fillet lugs. The rim is also lip notched (left to right notching). The vessel body has four sets of appliqued chevrons formed by diagonal opposed appliqued fillets. The chevrons extend to within $7.5 \mathrm{~cm}$ of the vessel base.

PIGMENT USE AND LOCATION ON VESSEL: none

TYPE AND VARIETY (IF KNOWN): Emory Punctated-Incised 
SITE NAME OR SITE NUMBER: George T. Wright Collection, Red River County, Texas

VESSEL NO.: GTW-419 [TX 115/1], B. R. R.

VESSEL FORM: Jar (Figure 46)

NON-PLASTICS AND PASTE: shell

RIM AND LIP FORM: Everted rim and rounded lip

CORE COLOR: B (fired and cooled in a reducing environment)

INTERIOR SURFACE COLOR: black; fire clouds on the base

EXTERIOR SURFACE COLOR: dark grayish-brown; fire clouds on the rim and body

WALL THICKNESS (IN MM): rim, 5.6 mm

INTERIOR SURFACE TREATMENT: smoothed

EXTERIOR SURFACE TREATMENT: smoothed on the body

HEIGHT (IN CM): 17.5

ORIFICE DIAMETER (IN CM): 18.0

DIAMETER AT BOTTOM OF RIM OR NECK (IN CM): 14.0

BASE DIAMETER (IN CM) AND SHAPE OF BASE: $8.0 \mathrm{~cm}$, circular and convex

ESTIMATED VOLUME (IN LITERS): 2.8

DECORATION (INCLUDING MOTIF AND ELEMENTS WHEN APPARENT): The vessel rim has four horizontal rows of tool punctations, one under the lip and the other three below the four bracket-shaped appliqued lugs. The vessel body has four sets of appliqued chevronshaped elements formed from diagonal opposed appliqued fillets (Figure 46). The chevron-shaped appliqued elements extend to within $5.5 \mathrm{~cm}$ of the vessel base.

PIGMENT USE AND LOCATION ON VESSEL:

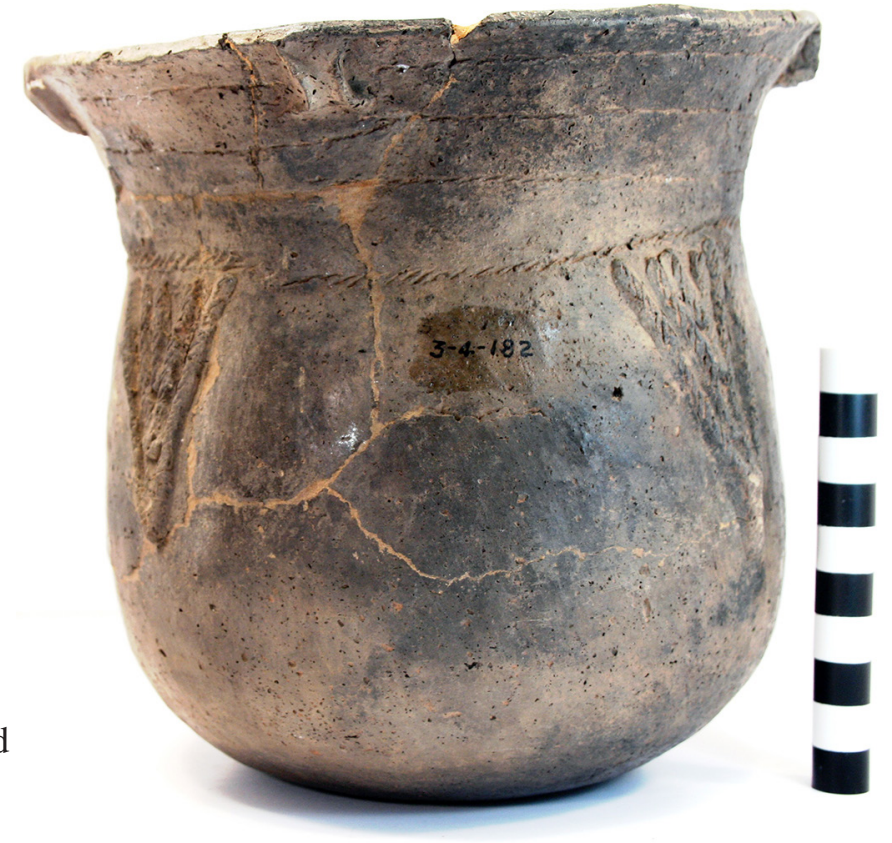

Figure 46. Emory Punctated-Incised jar, GTW-419. none

TYPE AND VARIETY (IF KNOWN): Emory Punctated-Incised 
SITE NAME OR SITE NUMBER: George T. Wright Collection, Red River County, Texas

VESSEL NO.: GTW-421 [TX 116/1], B. R. R.

VESSEL FORM: Jar (Figure 47)

NON-PLASTICS AND PASTE: shell

RIM AND LIP FORM: Everted rim and rounded lip

CORE COLOR: $\mathrm{G}$ (fired in a reducing environment and cooled in the open air)

INTERIOR SURFACE COLOR: dark grayish-brown; fire clouds on the rim and body

EXTERIOR SURFACE COLOR: dark yellowish-brown; fire clouds on the rim and body

WALL THICKNESS (IN MM): rim, $4.6 \mathrm{~mm}$; body, $5.5 \mathrm{~mm}$

INTERIOR SURFACE TREATMENT: smoothed

EXTERIOR SURFACE TREATMENT:

smoothed on the body

HEIGHT (IN CM): 22.0

ORIFICE DIAMETER (IN CM): 15.0

DIAMETER AT BOTTOM OF RIM OR NECK (IN CM): 14.0

BASE DIAMETER (IN CM) AND SHAPE OF BASE: $7.7 \mathrm{~cm}$, circular and flat

ESTIMATED VOLUME (IN LITERS): 3.0

DECORATION (INCLUDING MOTIF AND ELEMENTS WHEN APPARENT): The rim has four horizontal rows of smoothed appliqued fillets; the uppermost two rows are joined by bracket-shaped appliqued fillet elements or smoothed lugs. The lip of the vessel is notched from right to left (Figure 47). The vessel body has four vertical appliqued ridges that extend to within $6.0 \mathrm{~cm}$ of the vessel base.

PIGMENT USE AND LOCATION ON

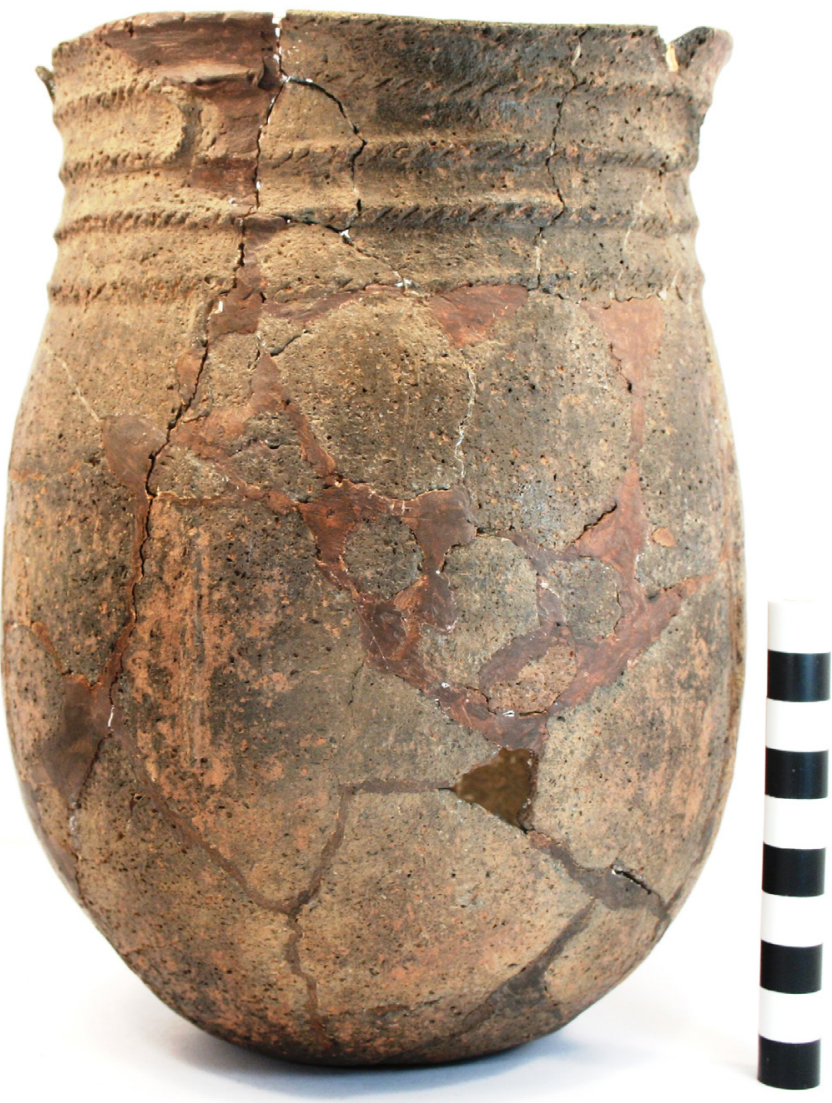

VESSEL: none

Figure 47. cf. Emory Punctated-Incised jar, GTW-421.

TYPE AND VARIETY (IF KNOWN): cf. Emory Punctated-Incised 
SITE NAME OR SITE NUMBER: George T. Wright Collection, Red River County, Texas

VESSEL NO.: GTW-421[a] [TX 116/1], B. R. R.

VESSEL FORM: Jar

NON-PLASTICS AND PASTE: shell

RIM AND LIP FORM: Everted rim and rounded, exterior folded lip

CORE COLOR: B (fired and cooled in a reducing environment)

INTERIOR SURFACE COLOR: black

EXTERIOR SURFACE COLOR: black

WALL THICKNESS (IN MM): rim, $4.3 \mathrm{~mm}$; body, $4.9 \mathrm{~mm}$

INTERIOR SURFACE TREATMENT: smoothed

EXTERIOR SURFACE TREATMENT: smoothed on the body

HEIGHT (IN CM): N/A

ORIFICE DIAMETER (IN CM): 18.0

DIAMETER AT BOTTOM OF RIM OR NECK (IN CM): N/A

BASE DIAMETER (IN CM) AND SHAPE OF BASE: N/A

ESTIMATED VOLUME (IN LITERS): N/A

DECORATION (INCLUDING MOTIF AND ELEMENTS WHEN APPARENT): The rim has four horizontal rows of smoothed appliqued fillets; the uppermost two rows are joined by appliqued fillet lug handles. The rim has been lip notched from right to left along the underside of the lip.

PIGMENT USE AND LOCATION ON VESSEL: none

TYPE AND VARIETY (IF KNOWN): cf. Emory Punctated-Incised 
SITE NAME OR SITE NUMBER: George T. Wright Collection, Red River County, Texas

VESSEL NO.: GTW-421[b] [TX 116/1], B. R. R.

VESSEL FORM: Jar

NON-PLASTICS AND PASTE: Shell

RIM AND LIP FORM: Unidentified rim profile and rounded lip

CORE COLOR: B (fired and cooled in a reducing environment)

INTERIOR SURFACE COLOR: dark grayish-brown

EXTERIOR SURFACE COLOR: dark grayish-brown

WALL THICKNESS (IN MM): rim, 3.9 mm

INTERIOR SURFACE TREATMENT: smoothed

EXTERIOR SURFACE TREATMENT: none

HEIGHT (IN CM): N/A

ORIFICE DIAMETER (IN CM): 12.0

DIAMETER AT BOTTOM OF RIM OR NECK (IN CM): N/A

BASE DIAMETER (IN CM) AND SHAPE OF BASE: N/A

ESTIMATED VOLUME (IN LITERS): N/A

DECORATION (INCLUDING MOTIF AND ELEMENTS WHEN APPARENT): The rim has a portion of two diagonal opposed appliqued fillets. The rim has also been notched right to left on the lip.

PIGMENT USE AND LOCATION ON VESSEL: none

TYPE AND VARIETY (IF KNOWN): Unidentified utility ware 
SITE NAME OR SITE NUMBER: George T. Wright Collection, Red River County, Texas

VESSEL NO.: GTW-433 [TX 117/1], B. R. R.

VESSEL FORM: Carinated bowl, hubcap form (see Suhm and Jelks 1962:Plate 71b-c) (Figure 48)

NON-PLASTICS AND PASTE: grog

RIM AND LIP FORM: Direct rim and a rounded lip

CORE COLOR: B (fired and cooled in a reducing environment)

INTERIOR SURFACE COLOR: black

EXTERIOR SURFACE COLOR: black

WALL THICKNESS (IN MM): rim, $4.1 \mathrm{~mm}$

INTERIOR SURFACE TREATMENT:

burnished

EXTERIOR SURFACE TREATMENT:

burnished

HEIGHT (IN CM): 7.2

ORIFICE DIAMETER (IN CM): 12.7

DIAMETER AT BOTTOM OF RIM OR NECK

(IN CM): 14.0

BASE DIAMETER (IN CM) AND SHAPE OF

BASE: $6.0 \mathrm{~cm}$, circular and convex

\section{ESTIMATED VOLUME (IN LITERS): 0.5}

\section{DECORATION (INCLUDING MOTIF AND}

ELEMENTS WHEN APPARENT): The lower

part of the rim panel is marked by a single

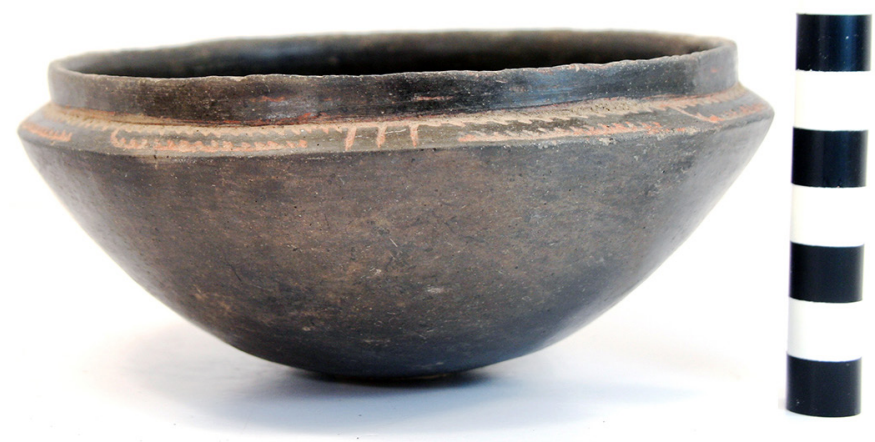

Figure 48. Simms Engraved, var. Darco carinated bowl, GTW-433. horizontal engraved line with downwardpointing excised tick marks; the rim panel is also divided into four areas by four sets of three vertical engraved lines. The inter-panel areas have discontinuous horizontal and curvilinear engraved lines with upward-pointing excised tick marks (Figure 48). The rim is notched from right to left on the vessel lip.

PIGMENT USE AND LOCATION ON VESSEL: red pigment rubbed in the engraved lines

TYPE AND VARIETY (IF KNOWN): Simms Engraved, var. Darco (see Perttula and Selden 2014:Figure 37) 
SITE NAME OR SITE NUMBER: George T. Wright Collection, Red River County, Texas

VESSEL NO.: GTW-445 [TX 118/1], B. R. R. Wright's notebook mentions that this vessel was found inside "another pot," but he neglected to mention what the other vessel was like.

VESSEL FORM: Carinated bowl with rounded shoulders (Figure 49)

NON-PLASTICS AND PASTE: shell

RIM AND LIP FORM: Everted rim and rounded lip

CORE COLOR: F (fired in a reducing environment and cooled in the open air)

INTERIOR SURFACE COLOR: reddish-brown

EXTERIOR SURFACE COLOR: reddish-brown; fire clouds on the rim and body

WALL THICKNESS (IN MM): rim, $3.2 \mathrm{~mm}$

INTERIOR SURFACE TREATMENT: smoothed

EXTERIOR SURFACE TREATMENT: burnished

HEIGHT (IN CM): 5.5

ORIFICE DIAMETER (IN CM): 6.5

DIAMETER AT BOTTOM OF RIM OR NECK

(IN CM): 6.2

BASE DIAMETER (IN CM) AND SHAPE OF

BASE: $2.8 \mathrm{~cm}$, circular and flat

ESTIMATED VOLUME (IN LITERS): 0.2

DECORATION (INCLUDING MOTIF AND

ELEMENTS WHEN APPARENT): The lower rim panel is defined by a single horizontal engraved line. The panel has four sets of rectangular engraved elements between sets of downward pointing pendant tick marks (Figure 49).

PIGMENT USE AND LOCATION ON VESSEL: none

TYPE AND VARIETY (IF KNOWN): Simms Engraved

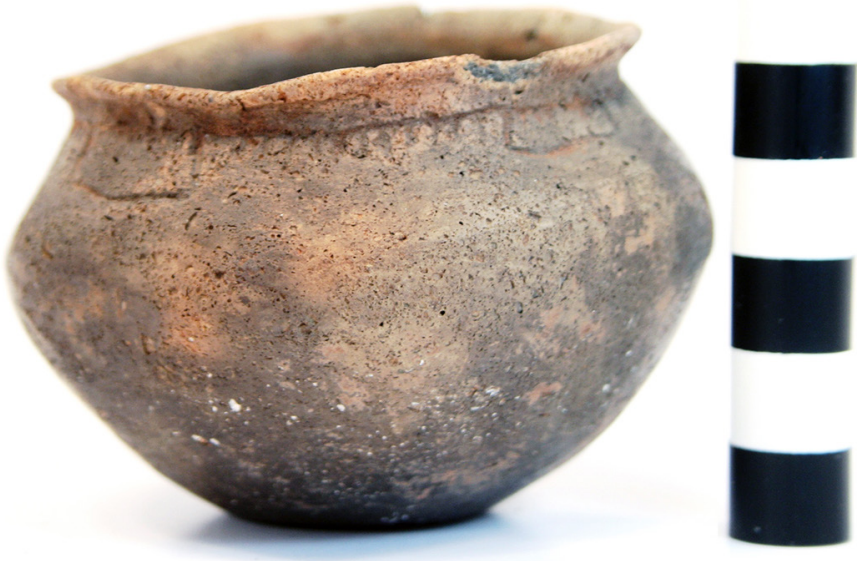

Figure 49. Simms Engraved carinated bowl, GTW445. 
SITE NAME OR SITE NUMBER: George T. Wright Collection, Red River County, Texas

VESSEL NO.: GTW-452 [TX 119/1], B. R. R.

VESSEL FORM: Carinated bowl (Figure 50)

NON-PLASTICS AND PASTE: grog

RIM AND LIP FORM: Everted rim and rounded lip

CORE COLOR: B (fired and cooled in a reducing environment)

INTERIOR SURFACE COLOR: black

EXTERIOR SURFACE COLOR: black

WALL THICKNESS (IN MM): rim, $5.4 \mathrm{~mm}$; body, $5.6 \mathrm{~mm}$

INTERIOR SURFACE TREATMENT: burnished on the rim

EXTERIOR SURFACE TREATMENT: burnished

HEIGHT (IN CM): 8.6

ORIFICE DIAMETER (IN CM): 17.8

DIAMETER AT BOTTOM OF RIM OR

NECK (IN CM): 18.5

BASE DIAMETER (IN CM) AND SHAPE

OF BASE: $7.5 \mathrm{~cm}$, circular and convex

ESTIMATED VOLUME (IN LITERS): 0.9

DECORATION (INCLUDING MOTIF AND ELEMENTS WHEN APPARENT):

The lower part of the rim panel is defined by a single horizontal engraved line, and the panel is divided into four areas by sets of two vertical engraved lines. Each area has a single horizontal and diagonal engraved line with either downward-pointing or upward-pointing tick marks (Figure 50). The rim of the vessel has also been notched from right to left on the lip.

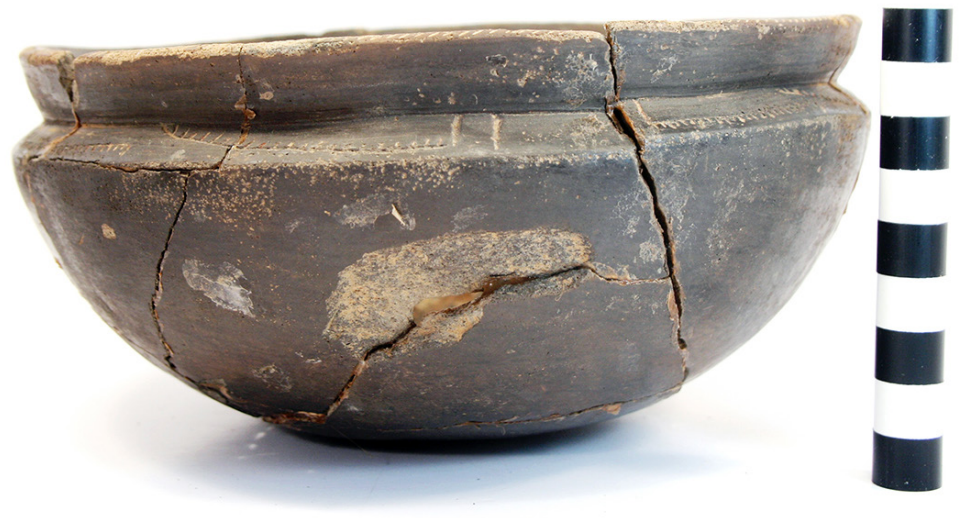

Figure 50. Simms Engraved, var. Darco carinated bowl, GTW-452.

PIGMENT USE AND LOCATION ON VESSEL: red pigment in the engraved lines

TYPE AND VARIETY (IF KNOWN): Simms Engraved, var. Darco 
SITE NAME OR SITE NUMBER: George T. Wright Collection, Red River County, Texas

VESSEL NO.: GTW-453 [TX 120/1], B. R. R.

VESSEL FORM: Carinated bowl (Figure 51a)

NON-PLASTICS AND PASTE: shell

RIM AND LIP FORM: Direct rim and rounded lip

CORE COLOR: B (fired and cooled in a reducing environment)

INTERIOR SURFACE COLOR: very dark reddish-brown

EXTERIOR SURFACE COLOR: very dark reddish-brown; fire clouds on the rim, body, and base

WALL THICKNESS (IN MM): rim, $6.5 \mathrm{~mm}$

INTERIOR SURFACE TREATMENT:

burnished on the rim

EXTERIOR SURFACE TREATMENT:

burnished

HEIGHT (IN CM): 8.8

ORIFICE DIAMETER (IN CM): 15.0

DIAMETER AT BOTTOM OF RIM OR

NECK (IN CM): 16.2

BASE DIAMETER (IN CM) AND SHAPE

OF BASE: $6.0 \mathrm{~cm}$, circular and convex

ESTIMATED VOLUME (IN LITERS): 0.8

DECORATION (INCLUDING MOTIF

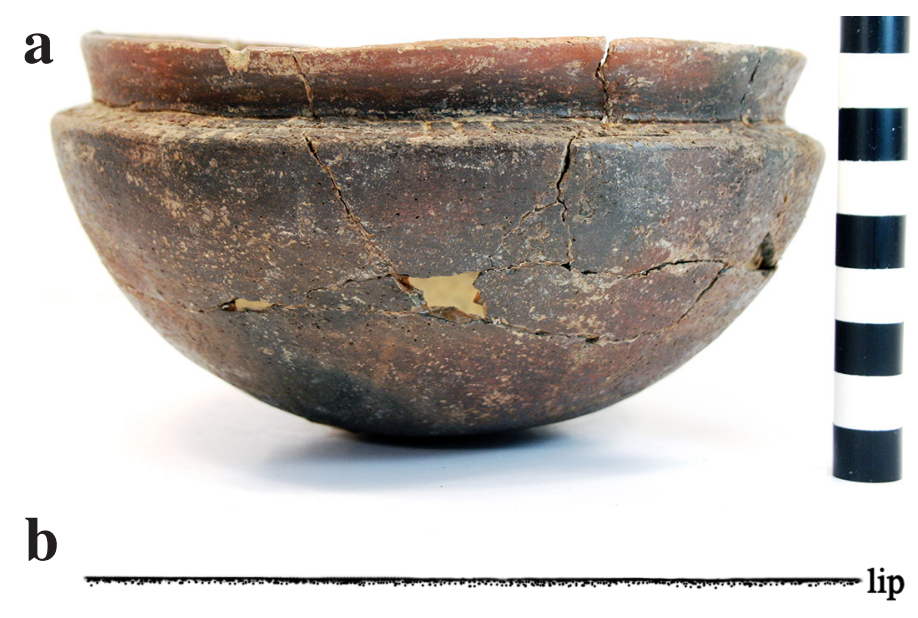

AND ELEMENTS WHEN APPARENT):

The lower rim panel on the vessel is defined

by a single horizontal engraved line. The panel is divided into seven areas by sets of three vertical

engraved lines. In each of these seven areas is a single horizontal engraved line with upwards-pointing

excised tick marks (Figure 51a-b).

PIGMENT USE AND LOCATION ON VESSEL: none

TYPE AND VARIETY (IF KNOWN): Simms Engraved 
SITE NAME OR SITE NUMBER: George T. Wright Collection, Red River County, Texas

VESSEL NO.: GTW-455 [TX 121/1], B. R. R.

VESSEL FORM: Carinated bowl (Figure 52a)

NON-PLASTICS AND PASTE: shell

RIM AND LIP FORM: Everted rim and rounded lip

CORE COLOR: B (fired and cooled in a reducing environment)

INTERIOR SURFACE COLOR: black

EXTERIOR SURFACE COLOR: black

WALL THICKNESS (IN MM): rim, 3.5

$\mathrm{mm}$

INTERIOR SURFACE TREATMENT:

burnished

EXTERIOR SURFACE TREATMENT:

burnished

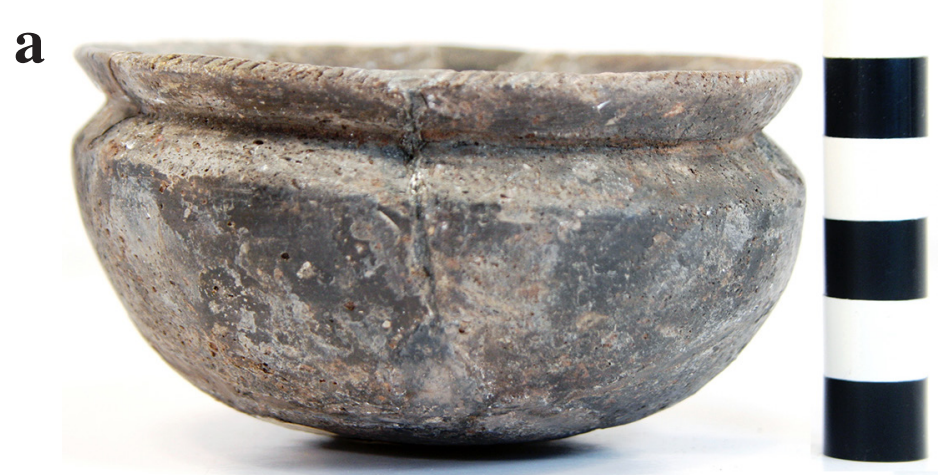

HEIGHT (IN CM): 5.2

b

ORIFICE DIAMETER (IN CM): 9.5

DIAMETER AT BOTTOM OF RIM

OR NECK (IN CM): 9.8

BASE DIAMETER (IN CM) AND

SHAPE OF BASE: $6.0 \mathrm{~cm}$, circular

and convex

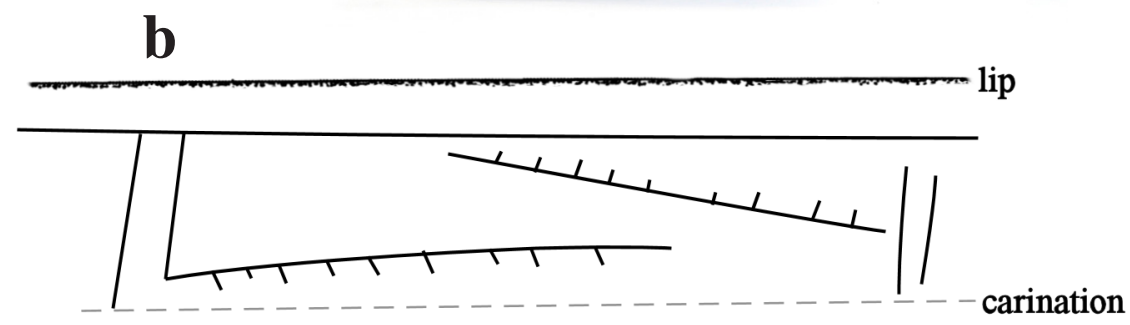

Figure 52. Simms Engraved, var. Darco carinated bowl, GTW455: a, side view; $b$, decorative elements.

ESTIMATED VOLUME (IN

LITERS): 0.3

DECORATION (INCLUDING MOTIF AND ELEMENTS WHEN APPARENT): The lower part of the rim panel is marked by a single horizontal engraved line; the upper part of the rim panel is plain. The lower panel is divided into four areas by sets of two vertical engraved lines. Each area has horizontal and diagonal engraved line with either downward- or upward-pointing tick marks (Figure 52a-b). The vessel rim has right to left lip notches.

PIGMENT USE AND LOCATION ON VESSEL: none

TYPE AND VARIETY (IF KNOWN): Simms Engraved, var. Darco 
SITE NAME OR SITE NUMBER: George T. Wright Collection, Red River County, Texas

VESSEL NO.: GTW-456 [TX 122/1], B. R. R.

VESSEL FORM: Bowl (Figure 53) with rounded shoulders

NON-PLASTICS AND PASTE: shell

RIM AND LIP FORM: Everted rim and rounded lip

CORE COLOR: B (fired and cooled in a reducing environment)

INTERIOR SURFACE COLOR: dark grayish-brown

EXTERIOR SURFACE COLOR: dark grayish-brown; fire clouds on the body and base

WALL THICKNESS (IN MM): rim, $3.6 \mathrm{~mm}$; body, $4.9 \mathrm{~mm}$

INTERIOR SURFACE TREATMENT: smoothed

EXTERIOR SURFACE TREATMENT: burnished

HEIGHT (IN CM): 8.0

ORIFICE DIAMETER (IN CM): 11.5

DIAMETER AT BOTTOM OF RIM OR NECK

(IN CM): 11.0

BASE DIAMETER (IN CM) AND SHAPE OF

BASE: $6.5 \mathrm{~cm}$, circular and convex

ESTIMATED VOLUME (IN LITERS): 0.4

DECORATION (INCLUDING MOTIF AND

ELEMENTS WHEN APPARENT): The lower

rim panel is marked by a single horizontal engraved line; the upper rim panel is plain. The panel has four sets of rectilinear engraved elements with upward-pointing tick marks on the lowermost engraved line (Figure 53). The decorative elements are similar to Inscribed $1 \mathrm{~b}$

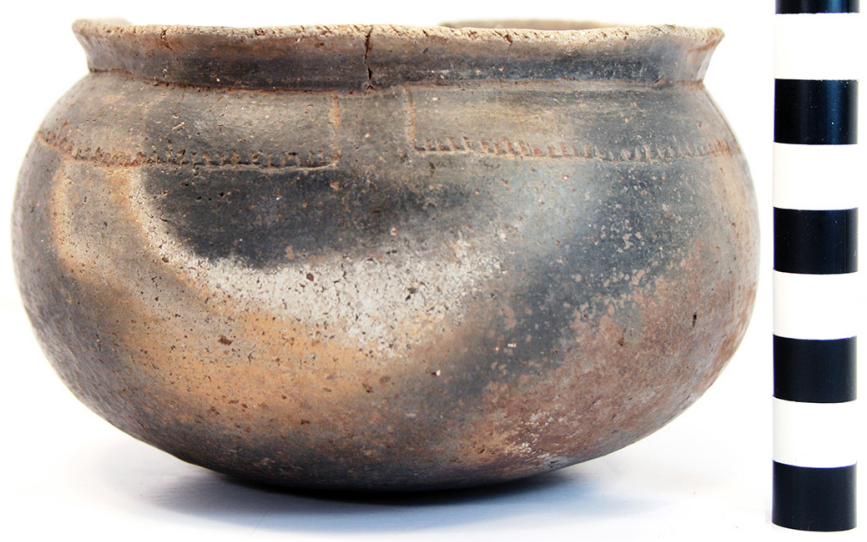

Figure 53. Simms Engraved bowl, GTW-456. on Simms Engraved vessels recognized by Dowd (2011:Figure 5.29), except that that vessel has tick marks along all lines. The rim has also been notched from left to right on the lip.

PIGMENT USE AND LOCATION ON VESSEL: none

TYPE AND VARIETY (IF KNOWN): Simms Engraved 
SITE NAME OR SITE NUMBER: George T. Wright Collection, Red River County, Texas

VESSEL NO.: GTW-458 [TX 123/1], B. R. R.

VESSEL FORM: Carinated bowl (Figure 54a)

NON-PLASTICS AND PASTE: shell

RIM AND LIP FORM: Everted rim and rounded lip

CORE COLOR: B (fired and cooled in a reducing environment)

INTERIOR SURFACE COLOR: black

EXTERIOR SURFACE COLOR: black

WALL THICKNESS (IN MM): rim, $3.3 \mathrm{~mm}$

INTERIOR SURFACE TREATMENT:

burnished

EXTERIOR SURFACE TREATMENT:

burnished

HEIGHT (IN CM): 7.8

ORIFICE DIAMETER (IN CM): 13.8

DIAMETER AT BOTTOM OF RIM OR

NECK (IN CM): 14.7

BASE DIAMETER (IN CM) AND

SHAPE OF BASE: $6.0 \mathrm{~cm}$, circular and convex

ESTIMATED VOLUME (IN LITERS):

0.6

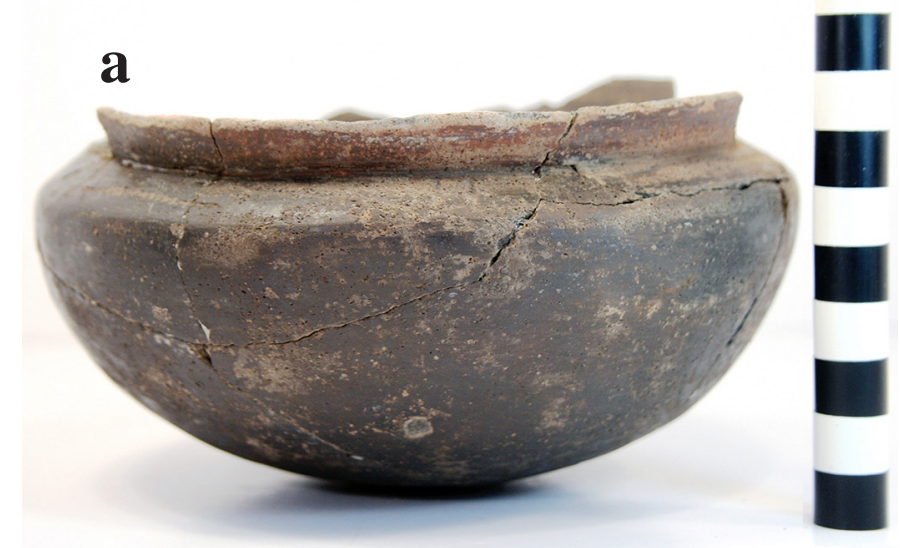

DECORATION (INCLUDING

MOTIF AND ELEMENTS WHEN

APPARENT): The lower rim panel is

b

$\operatorname{lip}$

defined by a single horizontal engraved

line; the upper rim panel is plain. The lower rim panel is divided into four areas by sets of two vertical engraved lines. Each area has a single horizontal engraved line and a diagonal engraved line with either upward- or downward-pointing tick marks. The two engraved lines do not touch (Figure 54a-b). The rim also has been notched on the lip.

PIGMENT USE AND LOCATION ON VESSEL: red pigment in the engraved lines

TYPE AND VARIETY (IF KNOWN): Simms Engraved, var. Darco 
SITE NAME OR SITE NUMBER: George T. Wright Collection, Red River County, Texas

VESSEL NO.: GTW-459 [TX 124/1), B. R. R.

VESSEL FORM: Carinated bowl with rounded shoulders (Figure 55a)

NON-PLASTICS AND PASTE: shell

RIM AND LIP FORM: Inverted and direct rim and rounded lip

CORE COLOR: B (fired and cooled in a reducing environment)

INTERIOR SURFACE COLOR: black

EXTERIOR SURFACE COLOR: very dark brown

WALL THICKNESS (IN MM): rim, $3.2 \mathrm{~mm}$

INTERIOR SURFACE TREATMENT: smoothed

EXTERIOR SURFACE TREATMENT: burnished

HEIGHT (IN CM): 6.3

ORIFICE DIAMETER (IN CM): 9.1

DIAMETER AT BOTTOM OF RIM

OR NECK (IN CM): 11.3

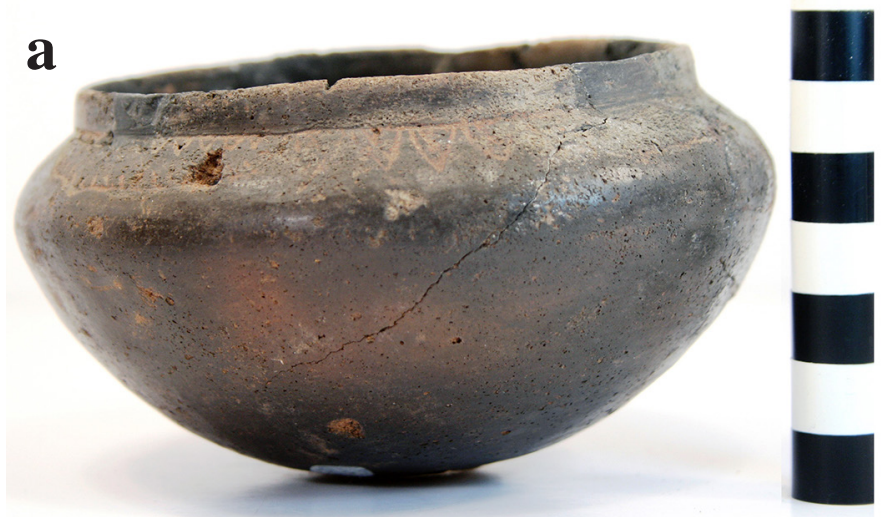

BASE DIAMETER (IN CM) AND

SHAPE OF BASE: $5.0 \mathrm{~cm}$, circular and convex

\section{b}

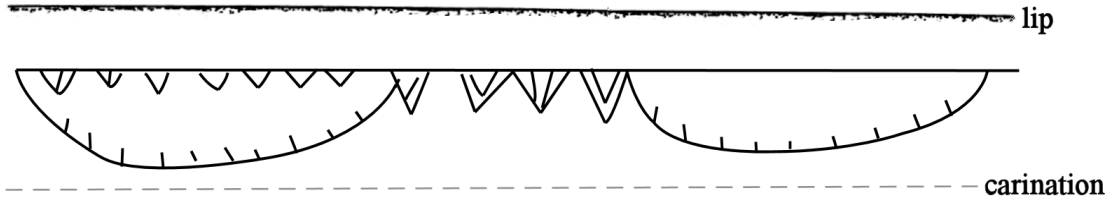

ESTIMATED VOLUME (IN

LITERS): 0.3

Figure 55. Simms Engraved carinated bowl, GTW-459: a, side view; b, decorative elements.

DECORATION (INCLUDING MOTIF AND ELEMENTS WHEN APPARENT): The lower rim panel has been marked by a single horizontal engraved line; the upper rim panel is plain. There are four sets of semi-circular engraved elements with upward-pointing tick marks on the lower part and hatched or open pendant triangles on the upper part. Between each of the semi-circular engraved elements are four larger hatched pendant triangles with their apexes pointing to the vessel carination (Figure 55a-b). The rim has also been notched on the lip.

PIGMENT USE AND LOCATION ON VESSEL: red pigment in the engraved lines TYPE AND VARIETY (IF KNOWN): Simms Engraved 
SITE NAME OR SITE NUMBER: George T. Wright Collection, Red River County, Texas

VESSEL NO.: GTW-460 [TX 125/1], B. R. R.

VESSEL FORM: Carinated bowl (Figure 56)

NON-PLASTICS AND PASTE: shell

RIM AND LIP FORM: Inverted rim and rounded lip

CORE COLOR: B (fired and cooled in a reducing environment)

INTERIOR SURFACE COLOR: black

EXTERIOR SURFACE COLOR: very dark grayish-brown

WALL THICKNESS (IN MM): rim, $3.2 \mathrm{~mm}$

INTERIOR SURFACE TREATMENT: smoothed

EXTERIOR SURFACE TREATMENT: burnished

HEIGHT (IN CM): 7.0

ORIFICE DIAMETER (IN CM): 11.1

DIAMETER AT BOTTOM OF RIM OR NECK (IN CM): 13.5

BASE DIAMETER (IN CM) AND SHAPE OF BASE: $4.8 \mathrm{~cm}$, circular and flat

ESTIMATED VOLUME (IN LITERS): 0.5

DECORATION (INCLUDING MOTIF AND ELEMENTS WHEN APPARENT): The lower rim panel is defined by a single horizontal engraved line; the upper rim panel is plain. The lower rim panel is divided into four areas by sets of three vertical and curvilinear engraved lines. Each of the areas has a horizontal engraved line with upward-pointing tick marks; in one case, the horizontal engraved line is discontinuous (Figure 56).

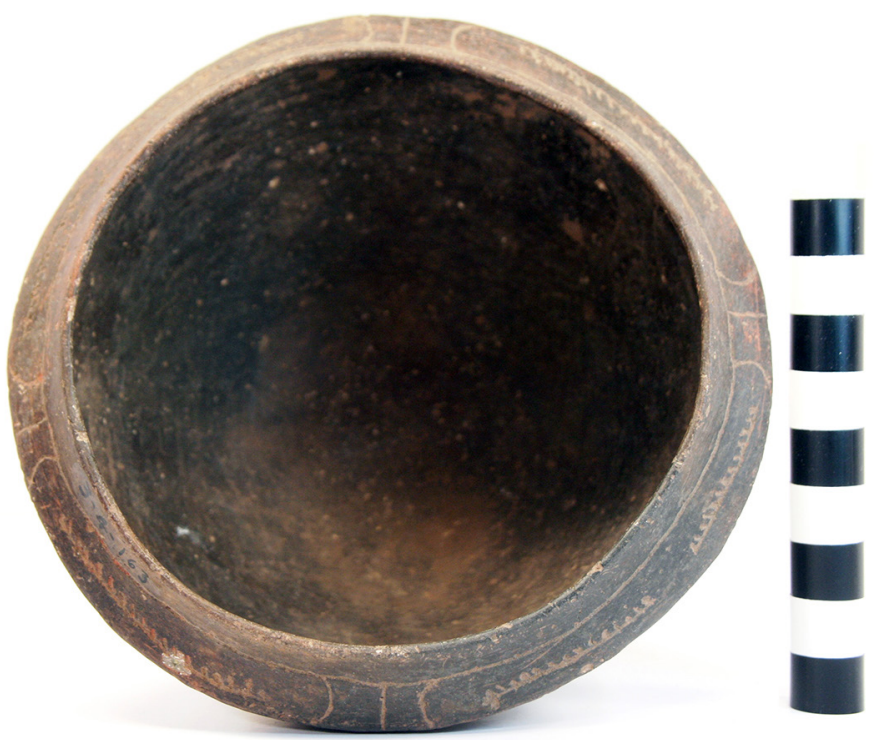

Figure 56. Top-down view of a Simms Engraved, var. Darco carinated bowl, GTW-460.

PIGMENT USE AND LOCATION ON

VESSEL: red pigment in the engraved lines

TYPE AND VARIETY (IF KNOWN): Simms Engraved, var. Darco 
SITE NAME OR SITE NUMBER: George T. Wright Collection, Red River County, Texas

VESSEL NO.: GTW-461a [TX 236/1], B. R. R.

VESSEL FORM: Carinated bowl, hubcap form (Figure 57a)

NON-PLASTICS AND PASTE: shell

RIM AND LIP FORM: Inverted and direct rim and rounded lip

CORE COLOR: B (fired and cooled in a reducing environment)

INTERIOR SURFACE COLOR: black

EXTERIOR SURFACE COLOR: very dark brown

WALL THICKNESS (IN MM): rim, 4.4 mm

INTERIOR SURFACE TREATMENT: burnished

EXTERIOR SURFACE TREATMENT: burnished

HEIGHT (IN CM): 6.0

ORIFICE DIAMETER (IN CM): 12.4

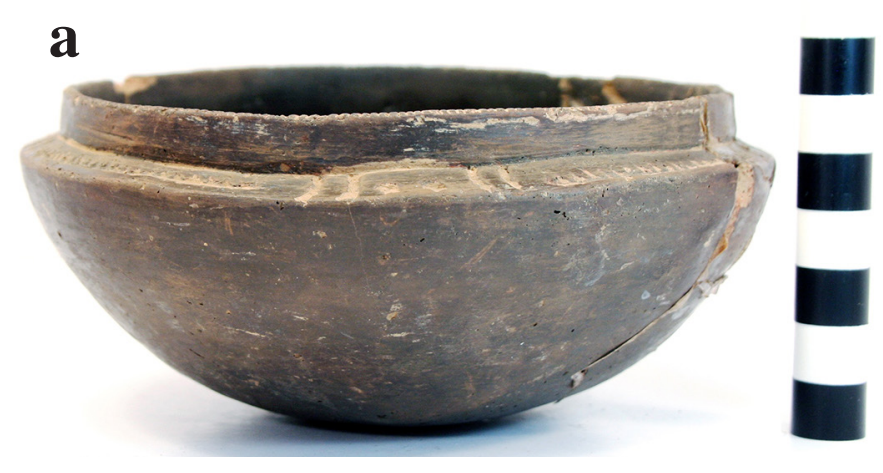

DIAMETER AT BOTTOM OF RIM OR NECK (IN CM): 14.0

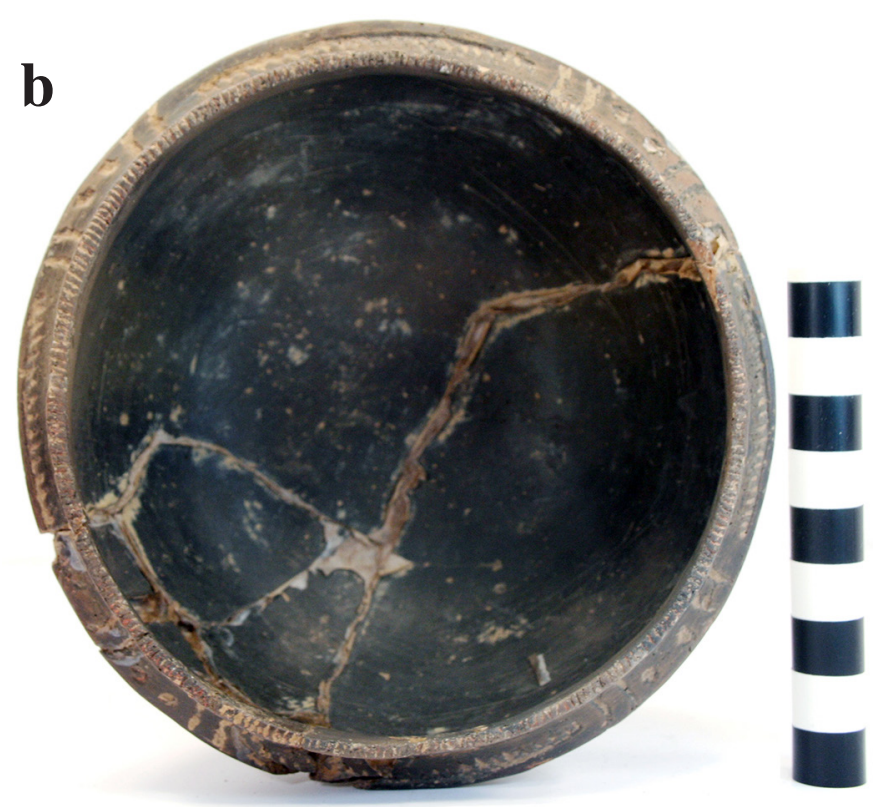

BASE DIAMETER (IN CM) AND SHAPE OF BASE: $6.0 \mathrm{~cm}$, circular and convex

ESTIMATED VOLUME (IN LITERS): 0.5

DECORATION (INCLUDING MOTIF AND

ELEMENTS WHEN APPARENT): The lower rim panel is defined by a single horizontal engraved line; the upper rim panel is plain. The lower rim panel is divided into four areas by sets of two curvilinearvertical engraved lines, with two excised punctations between the sets of two curvilinear engraved lines. The four areas each have a single horizontal engraved line with upward-pointing tick marks (Figure 57a-b).

PIGMENT USE AND LOCATION ON VESSEL: none

Figure 57. Simms Engraved carinated bowl, GTW461a: a, side view: $b$, looking down at the rim.

TYPE AND VARIETY (IF KNOWN): Simms Engraved 
SITE NAME OR SITE NUMBER: George T. Wright Collection, Red River County, Texas

VESSEL NO.: GTW-461b [TX 237/1], B. R. R.

VESSEL FORM: Carinated bowl (Figure 58a)

NON-PLASTICS AND PASTE: shell

RIM AND LIP FORM: Everted rim and rounded lip

CORE COLOR: B (fired and cooled in a reducing environment)

INTERIOR SURFACE COLOR: dark grayish-brown

EXTERIOR SURFACE COLOR: dark grayish-brown

WALL THICKNESS (IN MM): rim, 4.4 mm

INTERIOR SURFACE TREATMENT:

smoothed

EXTERIOR SURFACE TREATMENT:

smoothed

HEIGHT (IN CM): 8.0

ORIFICE DIAMETER (IN CM): 12.0

DIAMETER AT BOTTOM OF RIM OR NECK

(IN CM): 12.2

BASE DIAMETER (IN CM) AND SHAPE OF

BASE: $5.0 \mathrm{~cm}$, circular and convex

ESTIMATED VOLUME (IN LITERS): 0.6

b

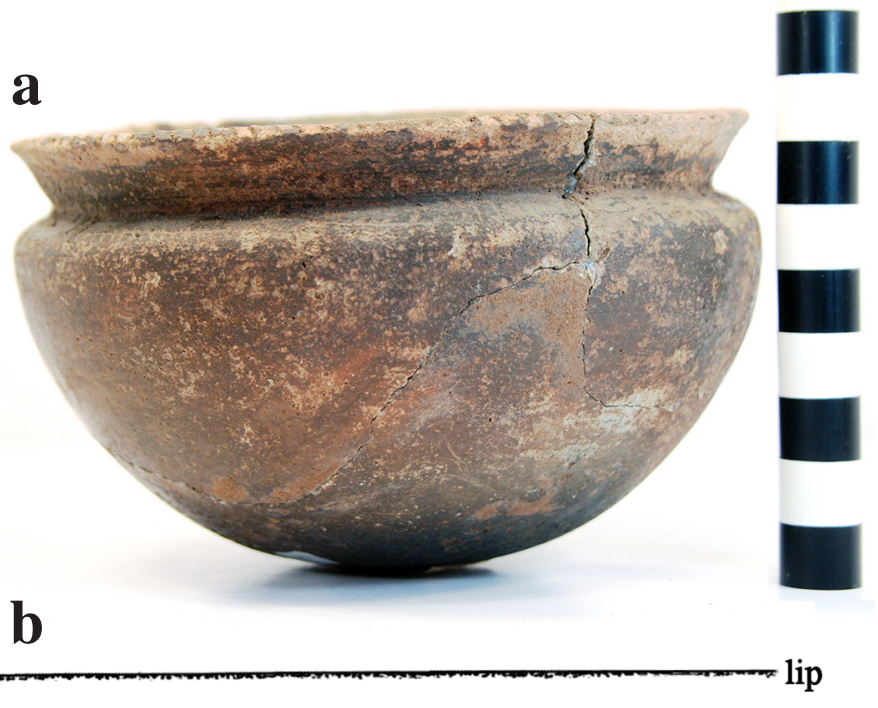

DECORATION (INCLUDING MOTIF AND

ELEMENTS WHEN APPARENT): The

vessel has a black slip on interior and exterior surfaces. The lower rim panel is marked by a single horizontal engraved line; the upper rim panel is plain. The lower rim panel is divided into four areas by sets of two vertical

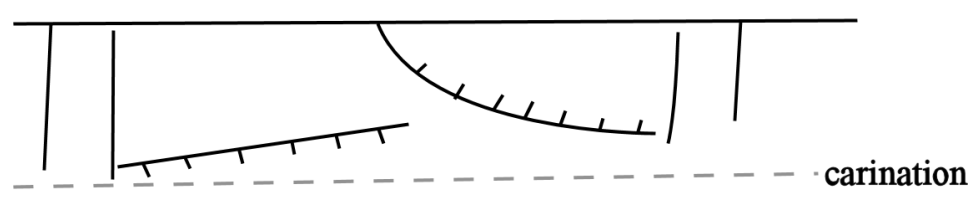

Figure 58. Simms Engraved, var. Darco carinated bowl, GTW-461b: a, side view' b, decorative elements. engraved lines. Within each of these areas is a single horizontal engraved line and a single diagonal engraved line with either upward- or downwardpointing tick marks; the two lines begin from opposing vertical engraved lines and do not touch (Figure 58a-b). The rim also has been notched from left to right on the rim.

PIGMENT USE AND LOCATION ON VESSEL: none

TYPE AND VARIETY (IF KNOWN): Simms Engraved, var. Darco 
SITE NAME OR SITE NUMBER: George T. Wright Collection, Red River County, Texas

VESSEL NO.: GTW-462 [TX 126/1], B. R. R.

VESSEL FORM: Carinated bowl (Figure 59)

NON-PLASTICS AND PASTE: shell

RIM AND LIP FORM: Direct rim and rounded lip

CORE COLOR: B (fired and cooled in a reducing environment)

INTERIOR SURFACE COLOR: dark grayish-brown; fire clouds on the rim

EXTERIOR SURFACE COLOR: dark grayish-brown

WALL THICKNESS (IN MM): rim, $5.0 \mathrm{~mm}$

INTERIOR SURFACE TREATMENT: smoothed

EXTERIOR SURFACE TREATMENT: burnished

HEIGHT (IN CM): 6.2

ORIFICE DIAMETER (IN CM): 13.8

DIAMETER AT BOTTOM OF RIM OR NECK (IN CM): 14.5

BASE DIAMETER (IN CM) AND SHAPE OF BASE: $7.0 \mathrm{~cm}$, circular and convex

ESTIMATED VOLUME (IN LITERS): 0.5

DECORATION (INCLUDING MOTIF AND

ELEMENTS WHEN APPARENT): There is a

black slip on the exterior vessel surface. The lower rim panel is defined by a single horizontal engraved line; the upper rim panel is plain. The lower rim panel is divided into four areas by sets of three vertical engraved lines (similar to Inscribed 1c Simms Engraved in Dowd [2011:Figure 5.30]), and there is a discontinuous horizontal engraved line above the vessel carination (Figure 59). The rim also has been notched from right to left on the lip.

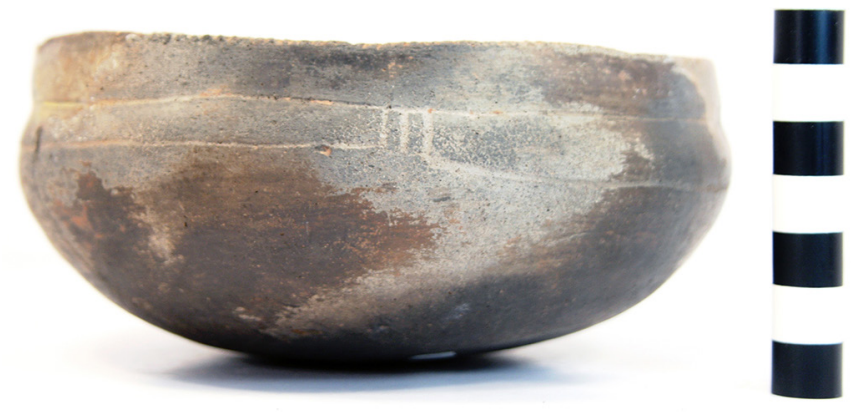

Figure 59. Simms Engraved carinated bowl, GTW462.

PIGMENT USE AND LOCATION ON VESSEL: none

TYPE AND VARIETY (IF KNOWN): Simms Engraved 
SITE NAME OR SITE NUMBER: George T. Wright Collection, Red River County, Texas

VESSEL NO.: GTW-463 [TX 127/1], B. R. R.

VESSEL FORM: Carinated bowl section (Figure 60a)

NON-PLASTICS AND PASTE: shell

RIM AND LIP FORM: Inverted-direct rim and flat lip

CORE COLOR: B (fired and cooled in a reducing environment)

INTERIOR SURFACE COLOR: black

EXTERIOR SURFACE COLOR: black

WALL THICKNESS (IN MM): rim, $4.3 \mathrm{~mm}$; body, $4.5 \mathrm{~mm}$

INTERIOR SURFACE TREATMENT: burnished

EXTERIOR SURFACE TREATMENT: burnished

HEIGHT (IN CM): 10.0

ORIFICE DIAMETER (IN CM): 16.0

DIAMETER AT BOTTOM OF RIM OR NECK

(IN CM): N/A

BASE DIAMETER (IN CM) AND SHAPE OF BASE: N/A

ESTIMATED VOLUME (IN LITERS): 1.0

DECORATION (INCLUDING MOTIF AND ELEMENTS WHEN APPARENT):

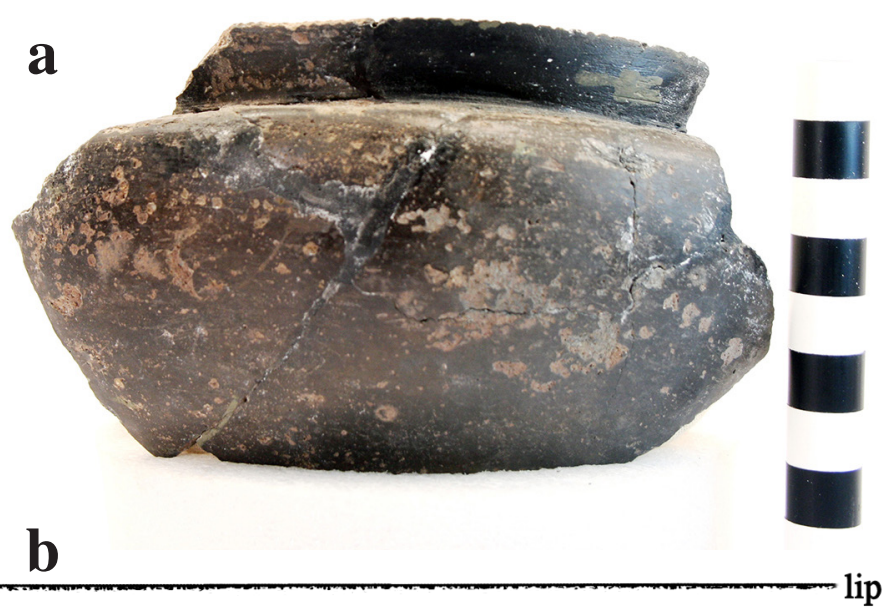

The lower rim panel is defined by a single horizontal engraved line; the upper rim panel is plain. The panel is divided into four areas by four sets of two vertical engraved lines. Each of the areas have single discontinuous horizontal and diagonal engraved lines with upward-pointed tick marks (Figure 60a-b). The rim also has been notched from right to left on the lip.

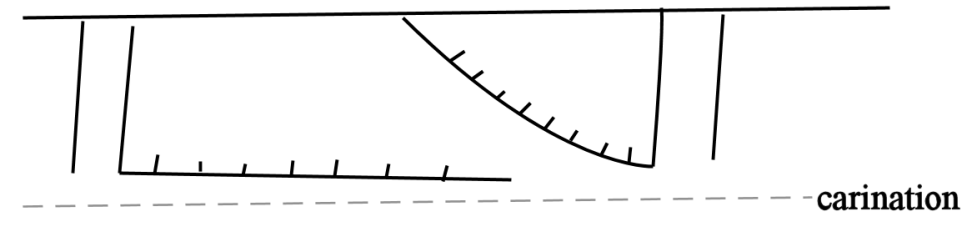

Figure 60. Simms Engraved, var. Darco carinated bowl section: a, side view; $b$, decorative elements.

PIGMENT USE AND LOCATION ON

VESSEL: none

TYPE AND VARIETY (IF KNOWN): Simms Engraved, var. Darco 
SITE NAME OR SITE NUMBER: George T. Wright Collection, Red River County, Texas

VESSEL NO.: GTW-468 [TX 128/1], B. R. R.

VESSEL FORM: Carinated bowl (Figure 61a)

NON-PLASTICS AND PASTE: shell

RIM AND LIP FORM: Inverted rim and rounded lip

CORE COLOR: B (fired and cooled in a reducing environment)

INTERIOR SURFACE COLOR: dark grayish-brown

EXTERIOR SURFACE COLOR: dark grayish-brown; fire clouds on the rim, body, and base

WALL THICKNESS (IN MM): rim, $3.3 \mathrm{~mm}$

INTERIOR SURFACE TREATMENT: smoothed

EXTERIOR SURFACE TREATMENT: burnished

HEIGHT (IN CM): 8.2

ORIFICE DIAMETER (IN CM): 17.0

DIAMETER AT BOTTOM OF RIM OR NECK

(IN CM): 18.0

BASE DIAMETER (IN CM) AND SHAPE OF

BASE: $7.0 \mathrm{~cm}$, circular and convex

ESTIMATED VOLUME (IN LITERS): 0.8

DECORATION (INCLUDING MOTIF AND

ELEMENTS WHEN APPARENT): The upper

rim panel has a grooved line, perhaps not a decorative element but a way to differentiate between the upper and lower rim panel.

The lower rim panel is defined by a single horizontal engraved line at the top, another horizontal engraved line at the bottom (and

$\mathbf{a}$

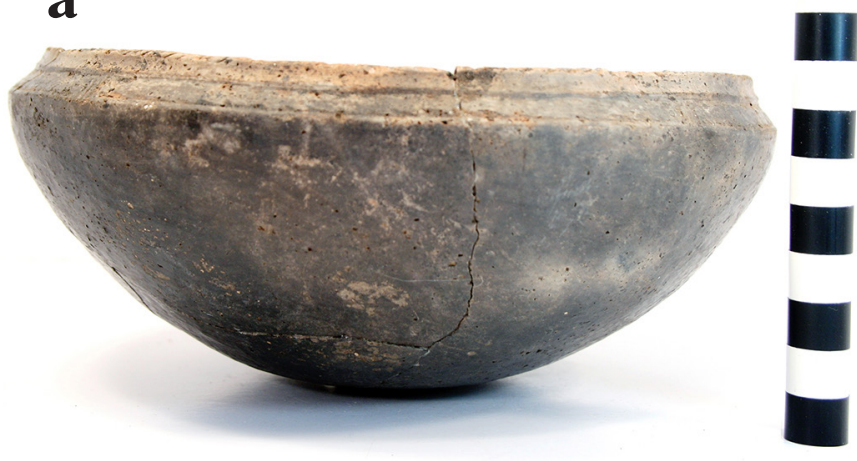

b

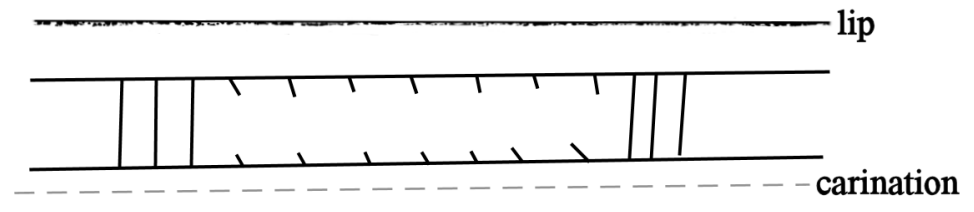

Figure 61. Simms Engraved carinated bowl, GTW468: a, side view; $b$, decorative elements. just above the carination), and four sets of three vertical engraved lines. The areas between the sets of vertical engraved lines have excised tick marks pendant from the upper and lower horizontal engraved lines with the panel (Figure 61a-b). The rim also has right to left (i.e., from back to front of the lip) notching on the lip.

PIGMENT USE AND LOCATION ON VESSEL: red pigment in the engraved lines 
SITE NAME OR SITE NUMBER: George T. Wright Collection, Red River County, Texas

VESSEL NO.: GTW-470 [TX 129/1], B. R. R.

VESSEL FORM: Carinated bowl (Figure 62)

NON-PLASTICS AND PASTE: shell

RIM AND LIP FORM: Everted rim and rounded lip

CORE COLOR: B (fired and cooled in a reducing environment)

INTERIOR SURFACE COLOR: black

EXTERIOR SURFACE COLOR: black

WALL THICKNESS (IN MM): rim, $4.0 \mathrm{~mm}$

INTERIOR SURFACE TREATMENT: smoothed

EXTERIOR SURFACE TREATMENT: burnished

HEIGHT (IN CM): 8.7

ORIFICE DIAMETER (IN CM): 15.4

DIAMETER AT BOTTOM OF RIM OR

NECK (IN CM): 16.0

BASE DIAMETER (IN CM) AND SHAPE

OF BASE: $7.0 \mathrm{~cm}$, circular and convex

ESTIMATED VOLUME (IN LITERS): 0.8

DECORATION (INCLUDING MOTIF AND ELEMENTS WHEN APPARENT): The lower rim panel is defined by a single horizontal engraved line; the upper rim panel is plain. The panel is divided into four areas by four sets of three vertical engraved lines. Each area has a single diagonal engraved line with upwardpointing tick marks (Figure 62). The rim is also notched from right to left on the lip.

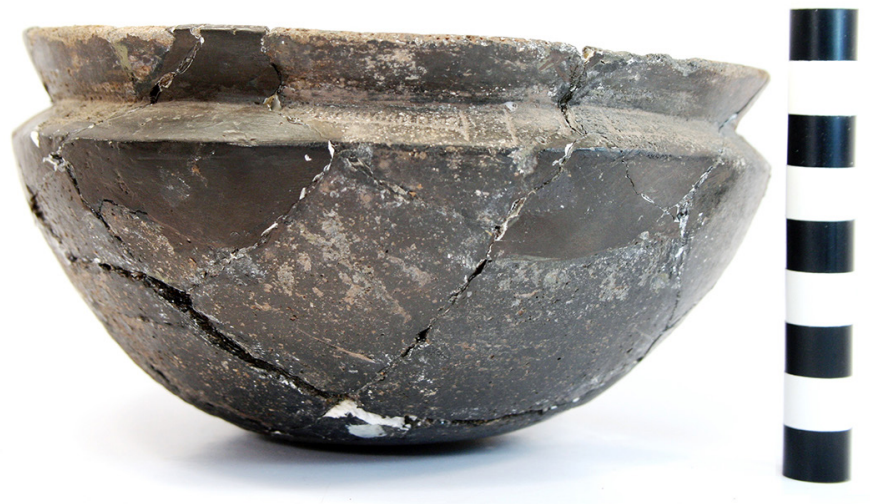

Figure 62. Simms Engraved, var. Darco carinated bowl, GTW-470.

PIGMENT USE AND LOCATION ON

VESSEL: none

TYPE AND VARIETY (IF KNOWN): Simms Engraved, var. Darco 
SITE NAME OR SITE NUMBER: George T. Wright Collection, Red River County, Texas

VESSEL NO.: GTW-472 [TX 130/1], B. R. R.

VESSEL FORM: Carinated bowl (Figure 63)

NON-PLASTICS AND PASTE: shell

RIM AND LIP FORM: Inverted-direct rim and rounded lip

CORE COLOR: B (fired and cooled in a reducing environment)

INTERIOR SURFACE COLOR: black

EXTERIOR SURFACE COLOR: black; fire clouds on the rim and body

WALL THICKNESS (IN MM): rim, 3.9 mm

INTERIOR SURFACE TREATMENT: burnished

EXTERIOR SURFACE TREATMENT: burnished

HEIGHT (IN CM): 10.7

ORIFICE DIAMETER (IN CM): 15.8

DIAMETER AT BOTTOM OF RIM OR NECK (IN CM): 17.1

BASE DIAMETER (IN CM) AND SHAPE OF BASE: $7.0 \mathrm{~cm}$, circular and rounded

ESTIMATED VOLUME (IN LITERS): 1.0

DECORATION (INCLUDING MOTIF AND

ELEMENTS WHEN APPARENT): The

lower rim panel is defined by upper and lower horizontal engraved lines; the upper rim panel is plain. The lower rim panel is divided into four areas by sets of three vertical engraved lines and sets of two outer curvilinear engraved lines. There are excised tick marks on each of the curvilinear engraved lines as well as upwardand downward-pointing tick marks on the horizontal engraved lines that define the panel (Figure 63). The rim is also notched from right to left on the lip.

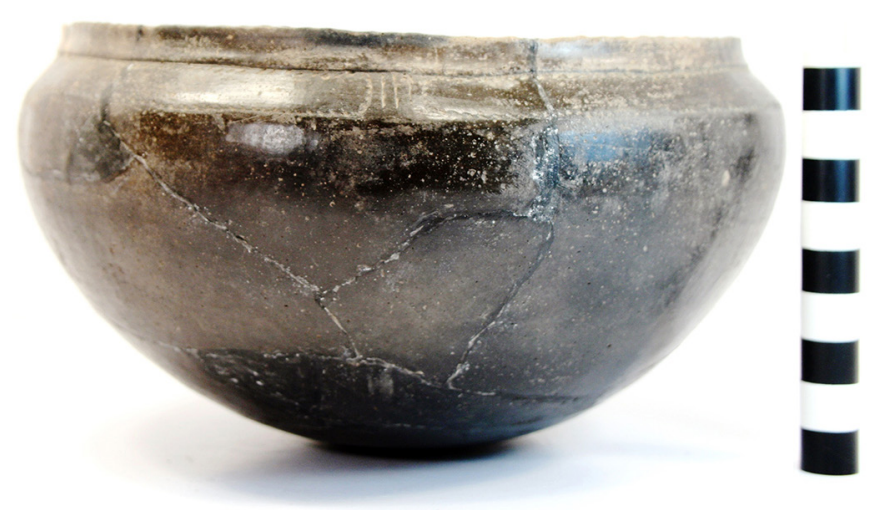

Figure 63. Simms Engraved carinated bowl, GTW472.

PIGMENT USE AND LOCATION ON

VESSEL: none

TYPE AND VARIETY (IF KNOWN): Simms Engraved 
SITE NAME OR SITE NUMBER: George T. Wright Collection, Red River County, Texas

VESSEL NO.: GTW-481 [TX 131/1], B. R. R.

VESSEL FORM: Effigy bowl with tab tail (Figure 64)

NON-PLASTICS AND PASTE: grog

RIM AND LIP FORM: Direct rim and flat lip

CORE COLOR: F (fired in a reducing environment and cooled in the open air)

INTERIOR SURFACE COLOR: dark yellowish-brown; fire clouds on the rim, body, and base

EXTERIOR SURFACE COLOR: brown; fire clouds on the rim, body, and base

WALL THICKNESS (IN MM): rim, $5.8 \mathrm{~mm}$

INTERIOR SURFACE TREATMENT: smoothed

EXTERIOR SURFACE TREATMENT: burnished

HEIGHT (IN CM): $7.3 ; 12.1 \mathrm{~cm}$ to the top of the effigy head

ORIFICE DIAMETER (IN CM): 18.1

DIAMETER AT BOTTOM OF RIM OR

NECK (IN CM): N/A

BASE DIAMETER (IN CM) AND SHAPE

OF BASE: $8.9 \mathrm{~cm}$, circular and rounded

ESTIMATED VOLUME (IN LITERS): 0.5

DECORATION (INCLUDING MOTIF AND ELEMENTS WHEN APPARENT): The

vessel has three widely-spaced smoothed over horizontal incised lines that intersect with a set of six concentric semi-circular lines under the tab tail (Figure 64). The top of the tab tail (20 $\mathrm{mm}$ in length and $48 \mathrm{~mm}$ in width) has an excised oval-shaped area.

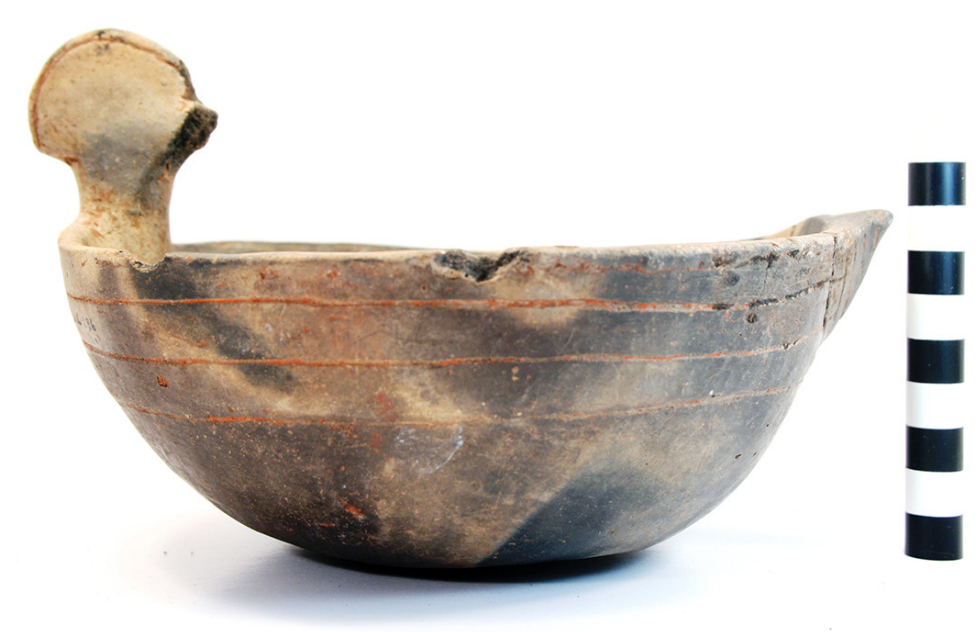

Figure 64. East Incised effigy bowl, GTW-481.

The bird-shaped effigy head faces inward towards the tab tail; it has three smoothed-over incised lines on the top and at the sides of the head (Figure 64). The effigy head is $48.0 \mathrm{~mm}$ in height, $13.0 \mathrm{~mm}$ in width, and $11.6 \mathrm{~mm}$ in thickness.

PIGMENT USE AND LOCATION ON VESSEL: red pigment in smoothed over incised lines

TYPE AND VARIETY (IF KNOWN): East Incised (see Suhm and Jelks 1962:41 and Plate 21) 
SITE NAME OR SITE NUMBER: George T. Wright Collection, Red River County, Texas

VESSEL NO.: GTW-486 [TX 133/1], B. R. R.

VESSEL FORM: Carinated bowl (Figure 65)

NON-PLASTICS AND PASTE: shell

RIM AND LIP FORM: Everted rim and rounded lip

CORE COLOR: B (fired and cooled in a reducing environment)

INTERIOR SURFACE COLOR: grayish-brown

EXTERIOR SURFACE COLOR: grayish-brown

WALL THICKNESS (IN MM): rim, 4.5 mm

INTERIOR SURFACE TREATMENT: smoothed

EXTERIOR SURFACE TREATMENT: smoothed

HEIGHT (IN CM): 7.0

ORIFICE DIAMETER (IN CM): 15.0

DIAMETER AT BOTTOM OF RIM OR NECK

(IN CM): 14.2

BASE DIAMETER (IN CM) AND SHAPE OF

BASE: $6.0 \mathrm{~cm}$, circular and convex

ESTIMATED VOLUME (IN LITERS): 0.6

DECORATION (INCLUDING MOTIF AND

ELEMENTS WHEN APPARENT): The lower

rim panel is defined by a single horizontal engraved line; the upper panel is plain. The lower panel is divided into four areas by vertical-horizontal engraved zones with diagonal hatched lines filling the horizontal zones. Within each of the four areas is a single horizontal and vertical scroll line (Figure 65).

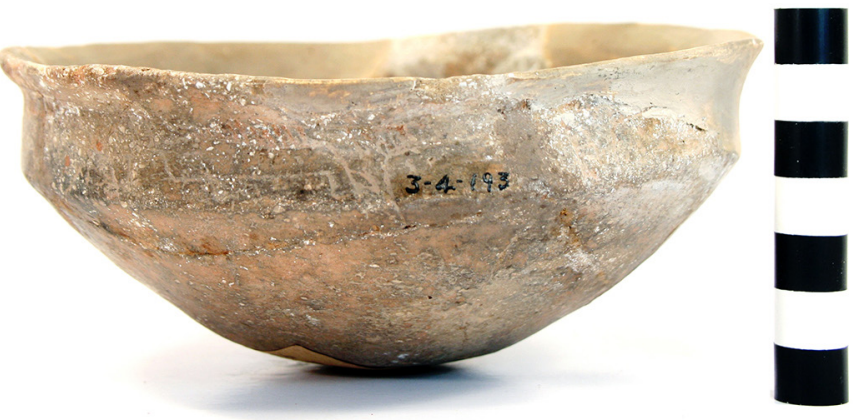

Figure 65. Simms Engraved carinated bowl, GTW486.

PIGMENT USE AND LOCATION ON VESSEL: none

TYPE AND VARIETY (IF KNOWN): Simms Engraved 
SITE NAME OR SITE NUMBER: George T. Wright Collection, Red River County, Texas

VESSEL NO.: GTW-487 [TX 134/1], B. R. R.

VESSEL FORM: Carinated bowl section (Figure 66)

NON-PLASTICS AND PASTE: shell

RIM AND LIP FORM: Inverted rim and rounded, exterior folded lip

CORE COLOR: B (fired and cooled in a reducing environment)

INTERIOR SURFACE COLOR: black

EXTERIOR SURFACE COLOR: black

WALL THICKNESS (IN MM): rim, $4.1 \mathrm{~mm}$; body, $4.2 \mathrm{~mm}$; base, $5.4 \mathrm{~mm}$

INTERIOR SURFACE TREATMENT: burnished

EXTERIOR SURFACE TREATMENT: burnished

HEIGHT (IN CM): 14.0

ORIFICE DIAMETER (IN CM): 17.0

DIAMETER AT BOTTOM OF RIM OR NECK (IN CM): N/A

BASE DIAMETER (IN CM) AND SHAPE OF BASE: $6.7 \mathrm{~cm}$, circular and flat

ESTIMATED VOLUME (IN LITERS):

1.4

DECORATION (INCLUDING MOTIF AND ELEMENTS WHEN APPARENT): The rim panel is divided into four parts by a negative SZ element surrounded by cross-hatched engraved lines. Each part has single outer vertical engraved lines, narrow horizontal and vertical hatched or cross-hatched zones, hatched spurs, and a central horizontal scroll element with rounded ends (Figure 66).

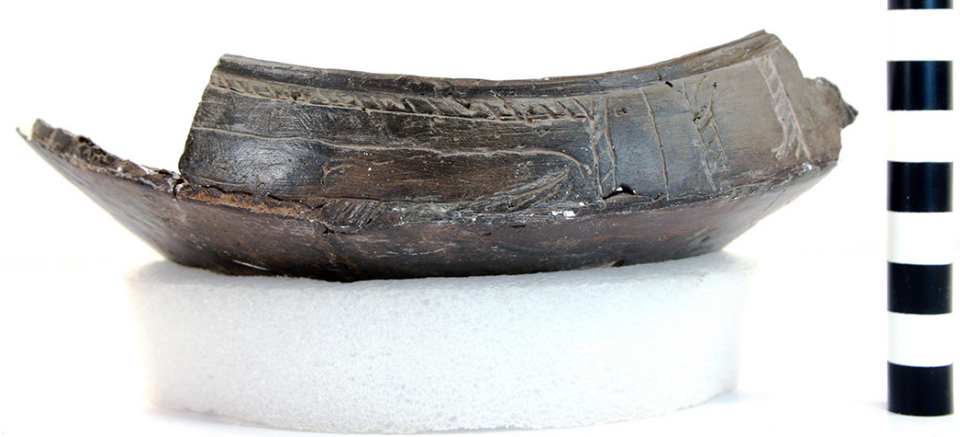

Figure 66. Simms Engraved carinated bowl section, GTW-487.

PIGMENT USE AND LOCATION ON

VESSEL: none

TYPE AND VARIETY (IF KNOWN): Simms Engraved 
SITE NAME OR SITE NUMBER: George T. Wright Collection, Red River County, Texas. Wright's notebook indicates that this vessel came from a site three miles northwest of Manchester, Texas. This would place the vessel as coming from a burial feature at the Wright Plantation site (41RR7).

VESSEL NO.: GTW-491 [TX 135/1], B. R. R.

VESSEL FORM: Jar section (Figure 67)

NON-PLASTICS AND PASTE: shell

RIM AND LIP FORM: Everted rim and rounded, exterior folded lip

CORE COLOR: B (fired and cooled in a reducing environment)

INTERIOR SURFACE COLOR: dark grayish-brown

EXTERIOR SURFACE COLOR: dark grayish-brown

WALL THICKNESS (IN MM): rim, $6.3 \mathrm{~mm}$; body, $5.4 \mathrm{~mm}$

INTERIOR SURFACE TREATMENT: smoothed

EXTERIOR SURFACE TREATMENT: none

HEIGHT (IN CM): rim height, $5.8 \mathrm{~cm}$

ORIFICE DIAMETER (IN CM): 20.0

DIAMETER AT BOTTOM OF RIM OR NECK

(IN CM): N/A

BASE DIAMETER (IN CM) AND SHAPE OF

BASE: N/A

ESTIMATED VOLUME (IN LITERS): N/A

DECORATION (INCLUDING MOTIF AND ELEMENTS WHEN APPARENT): The rim has four horizontal neck banded rows (Figure 67).

PIGMENT USE AND LOCATION ON

VESSEL: none

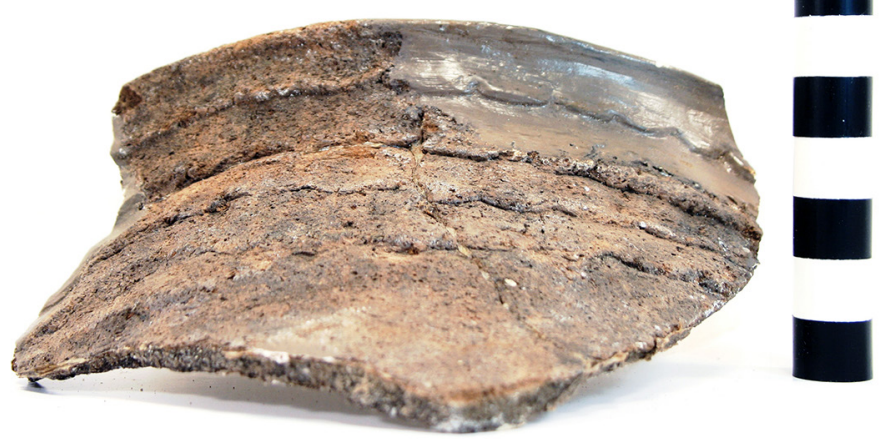

Figure 67. Nash Neck Banded jar section, GTW-491.

TYPE AND VARIETY (IF KNOWN): Nash

Neck Banded 
SITE NAME OR SITE NUMBER: George T. Wright Collection

VESSEL NO.: GTW-497 [TX 137/1]

VESSEL FORM: Compound bowl section (Figure 68)

NON-PLASTICS AND PASTE: shell

RIM AND LIP FORM: Everted rim and rounded lip

CORE COLOR: $\mathrm{F}$ (fired in a reducing environment but cooled in the open air)

INTERIOR SURFACE COLOR: red

EXTERIOR SURFACE COLOR: red

WALL THICKNESS (IN MM): rim, 4.9 mm

INTERIOR SURFACE TREATMENT: burnished

EXTERIOR SURFACE TREATMENT: burnished

HEIGHT (IN CM): $11.6 \mathrm{~cm}$, height of upper rim panel

ORIFICE DIAMETER (IN CM): 26.0

DIAMETER AT BOTTOM OF RIM OR NECK

(IN CM): 20.3 (base of upper rim panel)

BASE DIAMETER (IN CM) AND SHAPE OF BASE: N/A

ESTIMATED VOLUME (IN LITERS): N/A

DECORATION (INCLUDING MOTIF AND ELEMENTS WHEN APPARENT): The interior and exterior vessel surfaces have a red slip. On the upper rim panel, there is a single horizontal engraved line under the vessel lip, as well as a distinctive horizontal zone mid-rim on the panel. The horizontal zone is divided into six sections by excised brackets and single vertical engraved

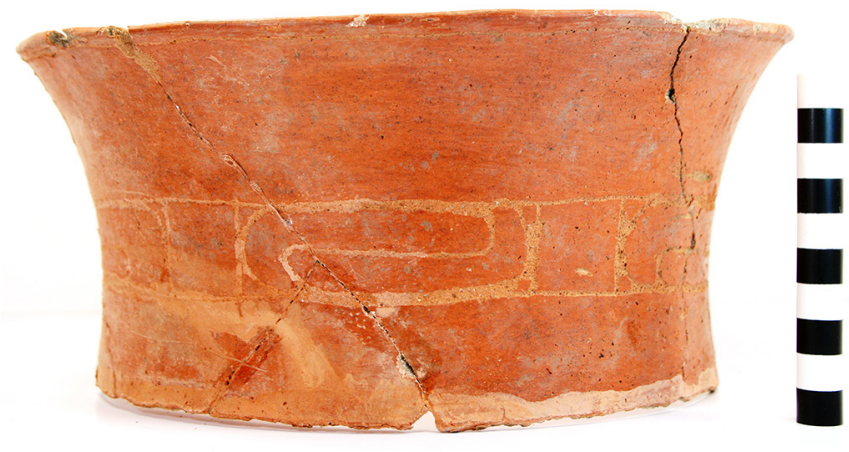

Figure 68. Avery Engraved compound bowl section, GTW-497. lines with attached excised bracket-shaped elements; portions of the scrolls within each section form part of the bracket-shaped elements. Within each section is a single horizontal engraved scroll with rounded ends; on one section there are triangularshaped excised areas attached to the scroll along with a single vertical engraved line (Figure 68).

PIGMENT USE AND LOCATION ON VESSEL: none

TYPE AND VARIETY (IF KNOWN): Avery Engraved 
SITE NAME OR SITE NUMBER: George T. Wright Collection, Titus County, Texas

VESSEL NO.: GTW-498 [TX 138/1), B. Titus

VESSEL FORM: Carinated bowl section (Figure 69)

NON-PLASTICS AND PASTE: grog

RIM AND LIP FORM: Direct rim and rounded, exterior folded lip

CORE COLOR: F (fired in a reducing environment and cooled in the open air)

INTERIOR SURFACE COLOR: brown; fire clouds on the rim and body

EXTERIOR SURFACE COLOR: brown; fire clouds on the rim and body

WALL THICKNESS (IN MM): rim, 5.7 mm; body, $6.8 \mathrm{~mm}$

INTERIOR SURFACE TREATMENT: smoothed

EXTERIOR SURFACE TREATMENT: burnished

HEIGHT (IN CM): 15.0+

ORIFICE DIAMETER (IN CM): 26.0

DIAMETER AT BOTTOM OF RIM OR NECK (IN CM): 26.0

BASE DIAMETER (IN CM) AND SHAPE

OF BASE: N/A

ESTIMATED VOLUME (IN LITERS):

$2.3+$

DECORATION (INCLUDING MOTIF AND ELEMENTS WHEN APPARENT):

The rim panel has four sets of engraved slanting scrolls with rounded ends. Above and below each of the slanting scrolls are scroll fill zones with negative ovals formed by excised bracket elements and excised triangle elements. The excised bracket elements have upper and lower negative

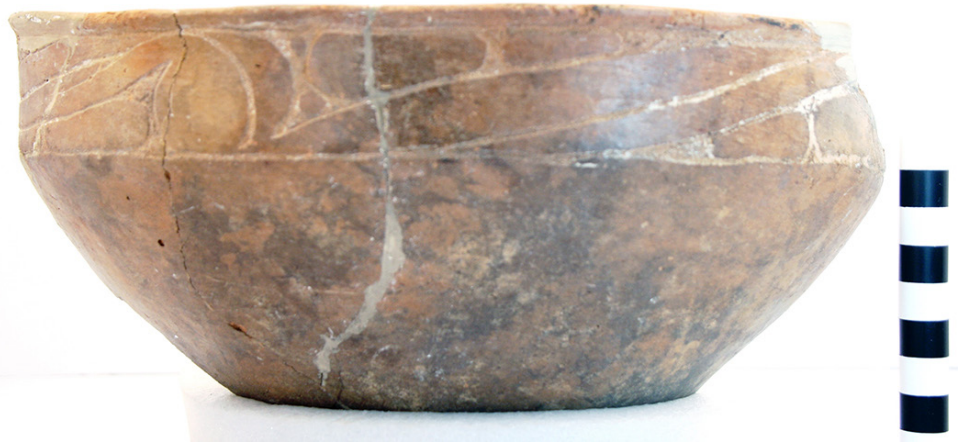

Figure 69. Ripley Engraved, var. Gandy carinated bowl section, GTW-498. ovals (Figure 69).

PIGMENT USE AND LOCATION ON VESSEL: white pigment in engraved lines TYPE AND VARIETY (IF KNOWN): Ripley Engraved, var. Gandy (see Fields et al. 2014:Table 8.6) 
SITE NAME OR SITE NUMBER: George T. Wright Collection, Red River County, Texas. Wright's notebook indicates that this vessel came from a site on Cuthand Creek.

VESSEL NO.: GTW-505 [TX 139/1], B. R. R.

VESSEL FORM: Carinated bowl section (Figure 70)

NON-PLASTICS AND PASTE: grog

RIM AND LIP FORM: N/A

CORE COLOR: $\mathrm{G}$ (fired in a reducing environment and cooled in the open air)

INTERIOR SURFACE COLOR: very dark grayish-brown

EXTERIOR SURFACE COLOR: yellowish-brown; fire clouds on the rim, body, and base

WALL THICKNESS (IN MM): rim, $8.2 \mathrm{~mm}$

INTERIOR SURFACE TREATMENT: none

EXTERIOR SURFACE TREATMENT: burnished

HEIGHT (IN CM): 10.2+

ORIFICE DIAMETER (IN CM):

27.8

DIAMETER AT BOTTOM OF RIM

OR NECK (IN CM): 27.8

BASE DIAMETER (IN CM) AND SHAPE OF BASE: $9.5 \mathrm{~cm}$, circular and flat

ESTIMATED VOLUME (IN

LITERS): $1.7+$

DECORATION (INCLUDING MOTIF AND ELEMENTS WHEN APPARENT): The remnant of this vessel has a single horizontal engraved line at the carination, and

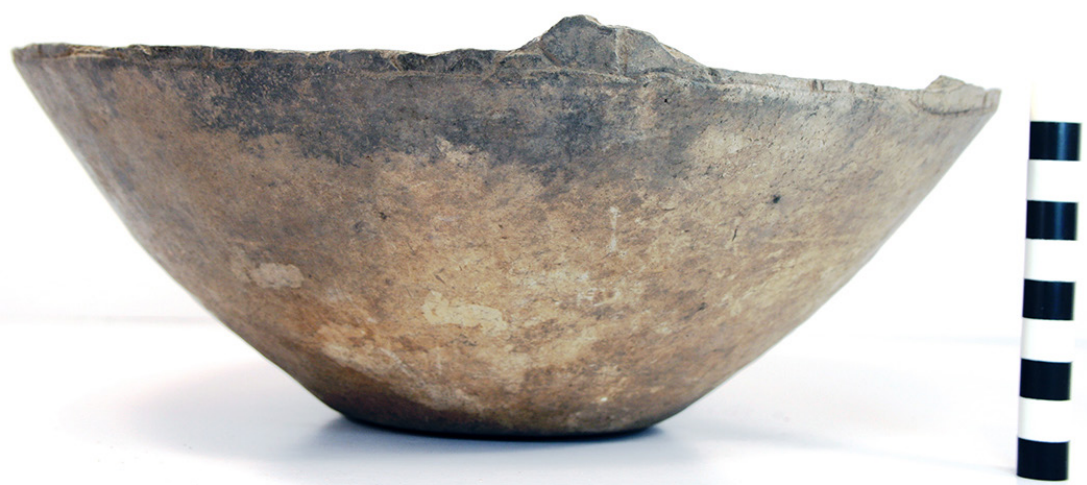

Figure 70. Engraved carinated bowl section, GTW-505. unidentified engraved elements above the carination (Figure 70).

PIGMENT USE AND LOCATION ON VESSEL: none TYPE AND VARIETY (IF KNOWN): Unidentified fine ware 
SITE NAME OR SITE NUMBER: George T. Wright Collection, Red River County, Texas

VESSEL NO.: GTW-507 [TX 140/1], S. R. R.

VESSEL FORM: Rattle bowl section (Figure 71)

NON-PLASTICS AND PASTE: shell

RIM AND LIP FORM: Inverted rim and rounded lip

CORE COLOR: F (fired in a reducing environment and cooled in the open air)

INTERIOR SURFACE COLOR: reddish-brown

EXTERIOR SURFACE COLOR: reddish-brown

WALL THICKNESS (IN MM): rim, $3.4 \mathrm{~mm}$; base, $5.0 \mathrm{~mm}$

INTERIOR SURFACE TREATMENT: smoothed

EXTERIOR SURFACE TREATMENT: burnished

HEIGHT (IN CM): 5.5

ORIFICE DIAMETER (IN CM): 8.0

DIAMETER AT BOTTOM OF RIM OR NECK (IN CM): N/A

BASE DIAMETER (IN CM) AND SHAPE OF

BASE: N/A

ESTIMATED VOLUME (IN LITERS): 0.2

DECORATION (INCLUDING MOTIF AND ELEMENTS WHEN APPARENT):

The vessel section has parts of two appliqued rattles covered with small appliqued nodes at the center of a series of three concentric engraved circles. The appliqued rattle is 4.0 $\mathrm{cm}$ in diameter and $3.3 \mathrm{~cm}$ in length. Between the rattle nodes are bracket-shaped engraved elements filled with circles and ovals as primary motifs (Figure 71) as well as vertical, diagonal, and horizontal hatching as secondary motifs (see Nash 2017:Table 2).

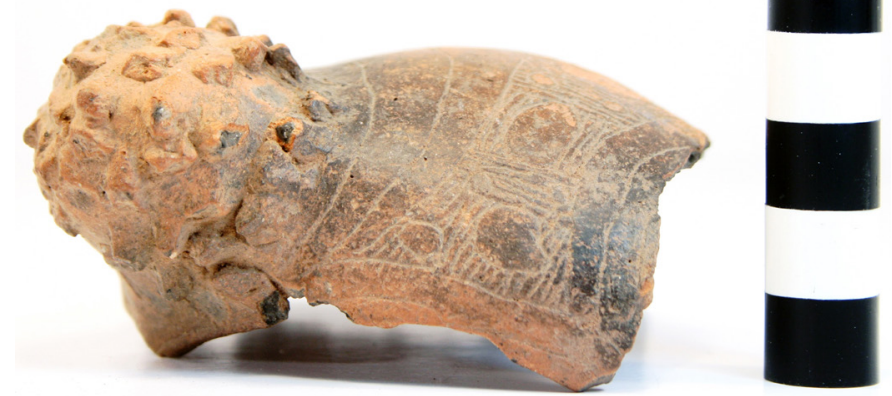

Figure 71. cf. Avery Engraved rattle bowl section, GTW-507.

PIGMENT USE AND LOCATION ON VESSEL: none

TYPE AND VARIETY (IF KNOWN): cf. Avery Engraved 
SITE NAME OR SITE NUMBER: George T. Wright Collection, Red River County, Texas

VESSEL NO.: GTW-508 [TX 141/1], B. R. R.

VESSEL FORM: Carinated bowl (Figure 72)

NON-PLASTICS AND PASTE: grog

RIM AND LIP FORM: Direct rim and rounded, exterior folded lip

CORE COLOR: F (fired in a reducing environment and cooled in the open air)

INTERIOR SURFACE COLOR: brown; fire clouds on the rim, body, and base

EXTERIOR SURFACE COLOR: brown; fire clouds on the rim, body, and base

WALL THICKNESS (IN MM): rim, $5.6 \mathrm{~mm}$

INTERIOR SURFACE TREATMENT: smoothed

EXTERIOR SURFACE TREATMENT: smoothed

HEIGHT (IN CM): 10.0

ORIFICE DIAMETER (IN CM):

15.2

DIAMETER AT BOTTOM OF

RIM OR NECK (IN CM): 15.2

BASE DIAMETER (IN CM) AND SHAPE OF BASE: $6.4 \mathrm{~cm}$, circular and flat

ESTIMATED VOLUME (IN

LITERS): 0.9

DECORATION (INCLUDING

MOTIF AND ELEMENTS WHEN

APPARENT): Plain (Figure 72)

PIGMENT USE AND LOCATION

ON VESSEL: none

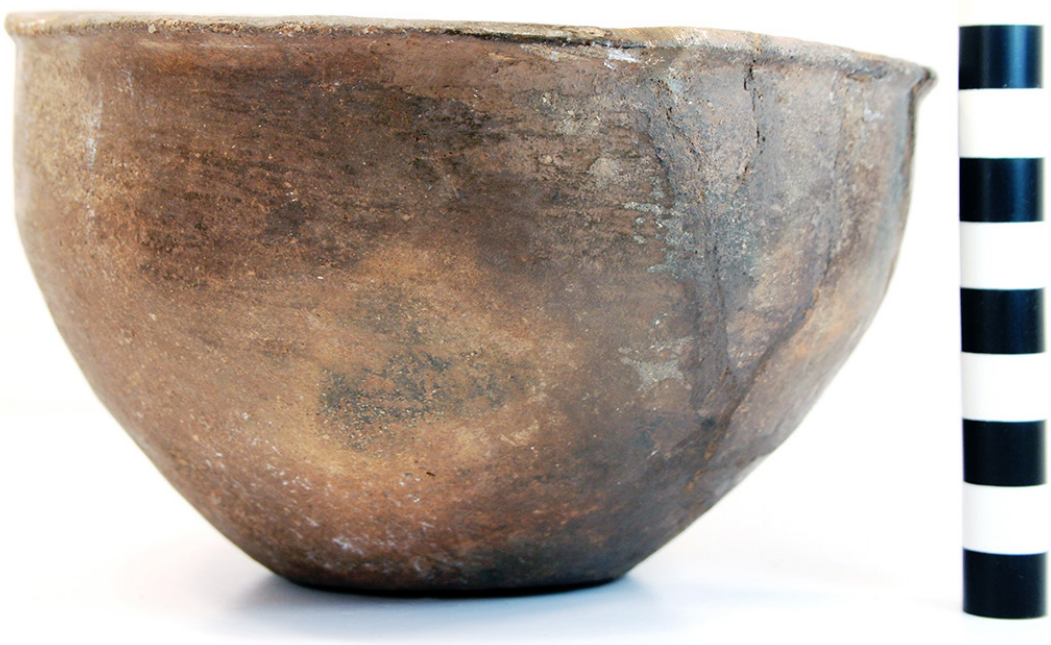

Figure 72. Plain carinated bowl, GTW-508.

TYPE AND VARIETY (IF

KNOWN): Unidentified plain ware 
SITE NAME OR SITE NUMBER: George T. Wright Collection, Red River County, Texas

VESSEL NO.: GTW-509 [TX 142/1], B. R. R.

VESSEL FORM: Bowl (Figure 73)

NON-PLASTICS AND PASTE: shell

RIM AND LIP FORM: Direct rim and rounded, exterior folded lip

CORE COLOR: $\mathrm{G}$ (fired in a reducing environment and cooled in the open air)

INTERIOR SURFACE COLOR: dark grayish-brown

EXTERIOR SURFACE COLOR: dark reddish-brown; fire clouds on the rim and body

WALL THICKNESS (IN MM): rim, $5.0 \mathrm{~mm}$

INTERIOR SURFACE TREATMENT: burnished

EXTERIOR SURFACE TREATMENT: burnished

HEIGHT (IN CM): 7.0

ORIFICE DIAMETER (IN CM): 13.3

DIAMETER AT BOTTOM OF RIM OR NECK (IN CM): N/A

BASE DIAMETER (IN CM) AND SHAPE OF BASE: $5.8 \mathrm{~cm}$, circular and flat

ESTIMATED VOLUME (IN LITERS): 0.4

DECORATION (INCLUDING MOTIF AND ELEMENTS WHEN APPARENT):

The vessel has upper and lower panels with engraved motifs and elements repeated five times on the upper panel and four times on the lower panel. The engraved motif consists of a single horizontal and vertical scroll line with horizontal and vertical scroll fill zones on either side of the scroll line that are filled with hatched lines. Each

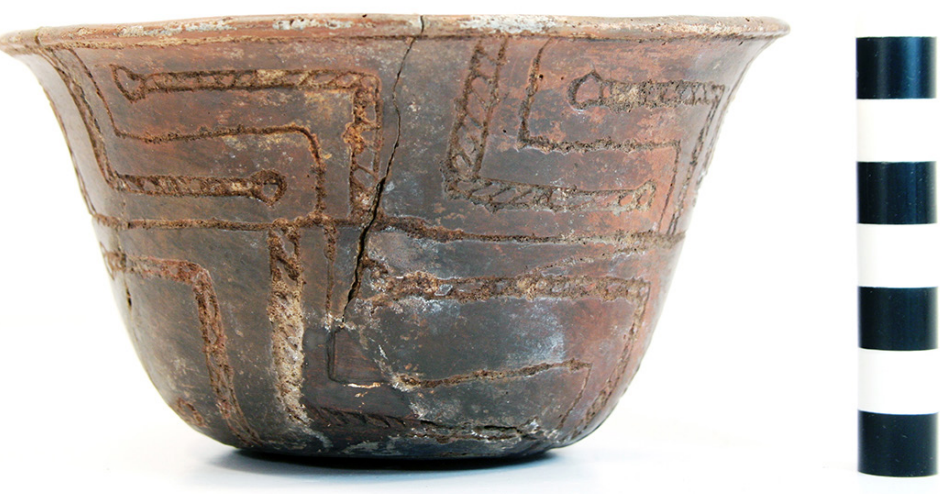

Figure 73. cf. Barkman Engraved bowl, GTW-509. of the scroll fill zones ends in an open engraved circle element (Figure 73). 
SITE NAME OR SITE NUMBER: George T. Wright Collection, Red River County, Texas VESSEL NO.: GTW-510 [TX 143/1], B. R. R.

VESSEL FORM: Bowl (Figure 74)

NON-PLASTICS AND PASTE: shell

RIM AND LIP FORM: Direct rim and rounded lip

CORE COLOR: F (fired in a reducing environment and cooled in the open air)

INTERIOR SURFACE COLOR: reddish-brown; fire clouds on the rim, body, and base

EXTERIOR SURFACE COLOR: reddish-brown; fire clouds on the rim, body, and base

WALL THICKNESS (IN MM): rim, $5.4 \mathrm{~mm}$

INTERIOR SURFACE TREATMENT: burnished

EXTERIOR SURFACE

TREATMENT: burnished

HEIGHT (IN CM): 4.5

ORIFICE DIAMETER (IN CM):

10.2

DIAMETER AT BOTTOM OF RIM

OR NECK (IN CM): N/A

BASE DIAMETER (IN CM) AND SHAPE OF BASE: $5.1 \mathrm{~cm}$, circular and flat

ESTIMATED VOLUME (IN

LITERS): 0.2

DECORATION (INCLUDING MOTIF AND ELEMENTS WHEN APPARENT): Plain (Figure 74)

PIGMENT USE AND LOCATION ON VESSEL: none

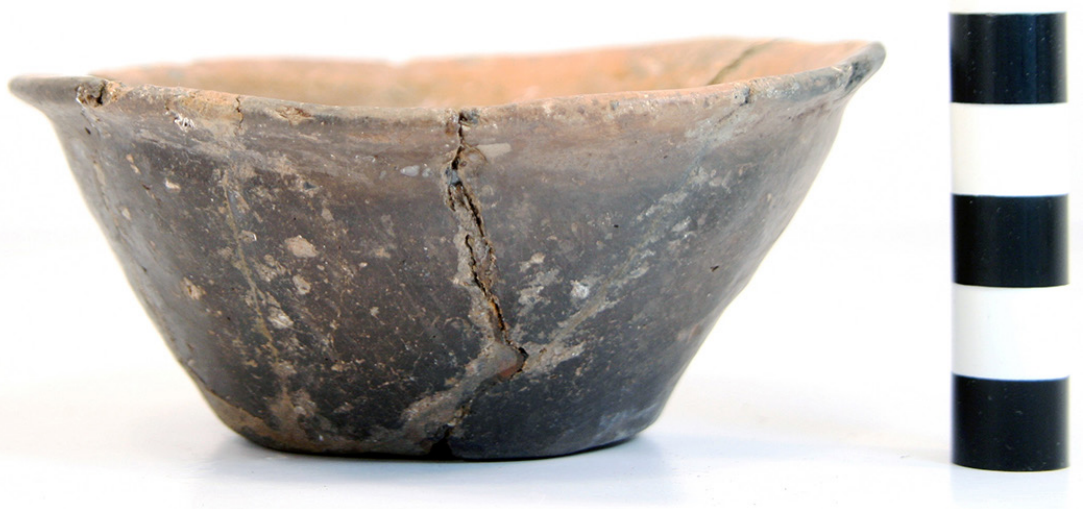

Figure 74. Plain bowl, GTW-510.

TYPE AND VARIETY (IF KNOWN): Unidentified plain ware 
SITE NAME OR SITE NUMBER: George T. Wright Collection, Red River County, Texas

VESSEL NO.: GTW-519 [TX 144/1], B. R. R.

VESSEL FORM: Beaker with opposed suspension holes (2.2 $\mathrm{mm}$ in diameter) (Figure 75)

NON-PLASTICS AND PASTE: shell

RIM AND LIP FORM: Direct rim and rounded lip

CORE COLOR: B (fired and cooled in a reducing environment)

INTERIOR SURFACE COLOR: dark grayishbrown

EXTERIOR SURFACE COLOR: dark grayishbrown

WALL THICKNESS (IN MM): rim, $5.2 \mathrm{~mm}$

INTERIOR SURFACE TREATMENT: smoothed

EXTERIOR SURFACE TREATMENT: burnished

HEIGHT (IN CM): 9.3

ORIFICE DIAMETER (IN CM): 5.3

DIAMETER AT BOTTOM OF RIM OR NECK

(IN CM): N/A

BASE DIAMETER (IN CM) AND SHAPE OF

BASE: $7.1 \mathrm{~cm}$, circular and rounded

ESTIMATED VOLUME (IN LITERS): 0.4

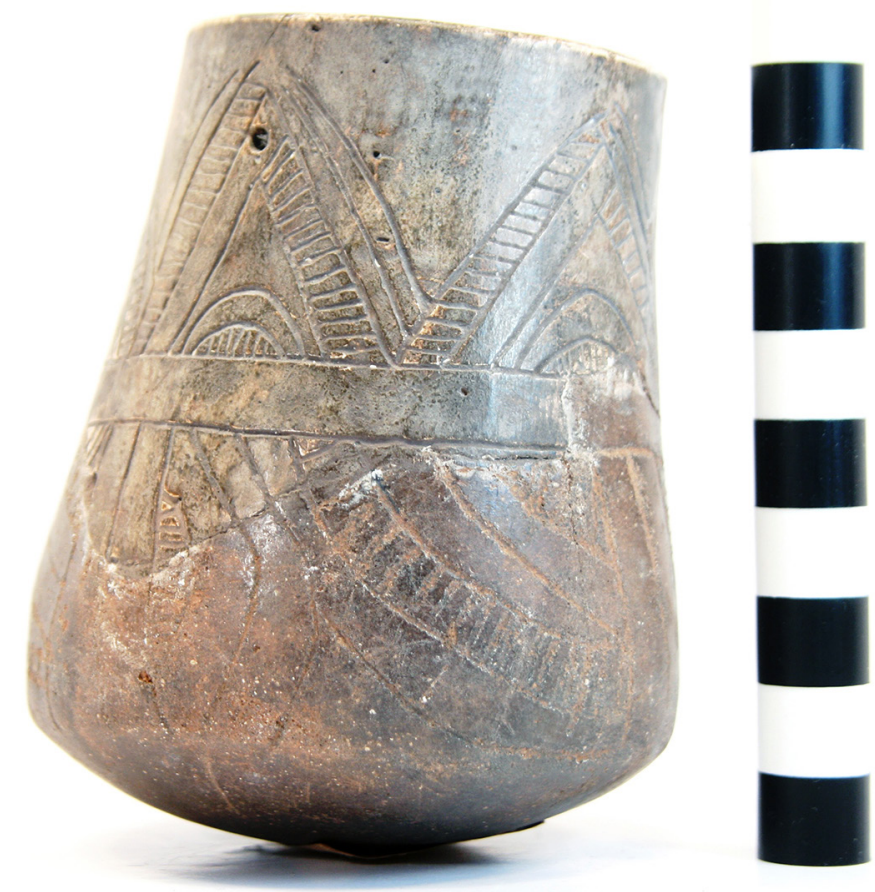

Figure 75. Avery Engraved beaker, GTW-519.

DECORATION (INCLUDING MOTIF AND ELEMENTS WHEN APPARENT): The beaker is divided into upper and lower panels by a single horizontal engraved line. The upper panel has four sets of triangles marked by diagonal engraved lines and hatched diagonal lines, with triangle and hatched semicircular elements nested within (Figure 75); this decorative motif is similar to the Inscribed 3b (Avery Engraved) defined by Dowd (2011:65 and Figure 5.35).

The lower panel has three sets of three vertical engraved lines. The areas between the vertical engraved lines are filled with sets of curvilinear engraved lines, a hatched curvilinear zone, a hatched semi-circle element pendant from a vertical engraved line, and an excised pendant triangle element (Figure 75).

PIGMENT USE AND LOCATION ON VESSEL: none

TYPE AND VARIETY (IF KNOWN): Avery Engraved 
SITE NAME OR SITE NUMBER: George T. Wright Collection, Red River County, Texas. Wright's notebook indicates this vessel came from a site in the southeastern corner of Red River County in the Sulphur River basin.

VESSEL NO.: GTW-521 [TX 145/1], B. R. R.

VESSEL FORM: Deep bowl (Figure 76)

NON-PLASTICS AND PASTE: grog, bone, and hematite

RIM AND LIP FORM: Direct rim and rounded lip

CORE COLOR: $\mathrm{G}$ (fired in a reducing environment and cooled in the open air)

INTERIOR SURFACE COLOR: grayish-brown; fire clouds on the rim, body, and base

EXTERIOR SURFACE COLOR: dark yellowish-brown; fire clouds on the rim, body, and base

WALL THICKNESS (IN MM): rim, $5.8 \mathrm{~mm}$

INTERIOR SURFACE TREATMENT:

smoothed

EXTERIOR SURFACE TREATMENT: smoothed

HEIGHT (IN CM): 14.0

ORIFICE DIAMETER (IN CM): 17.2

DIAMETER AT BOTTOM OF RIM

OR NECK (IN CM): N/A

BASE DIAMETER (IN CM) AND

SHAPE OF BASE: $11.0 \mathrm{~cm}$, circular and flat

ESTIMATED VOLUME (IN LITERS):

1.9

DECORATION (INCLUDING

MOTIF AND ELEMENTS WHEN

APPARENT): The rim has six sets of

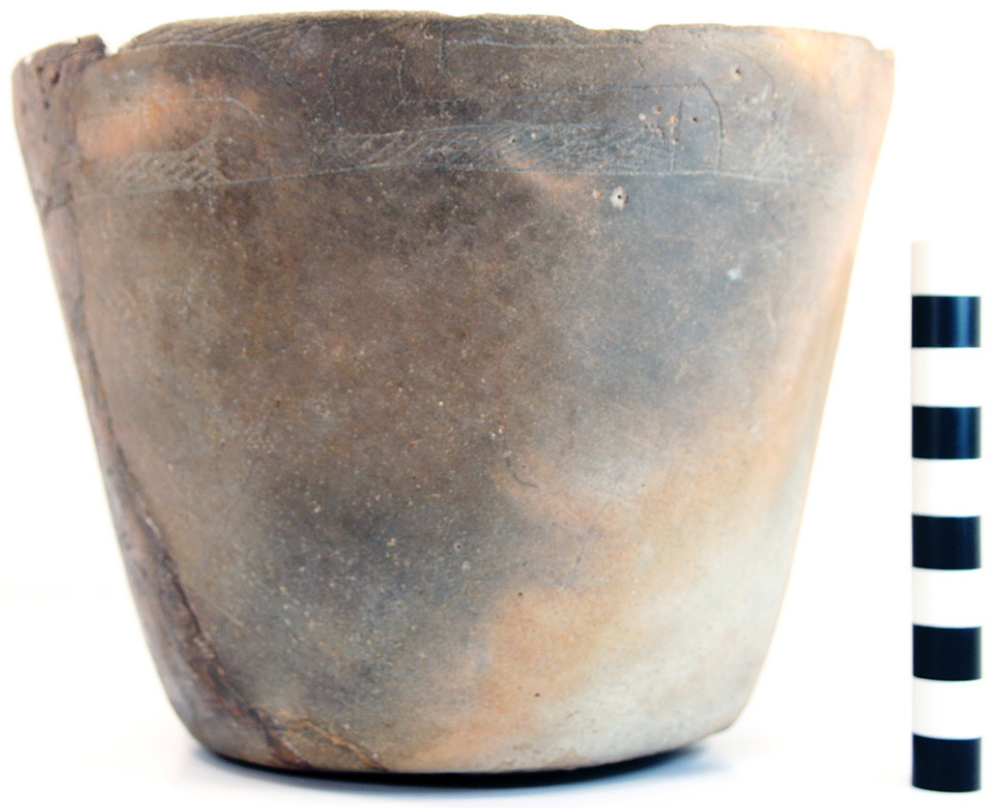

Figure 76. Unidentified fine ware deep bowl, GTW-521. engraved horizontal and vertical scroll lines with rounded ends. The scroll lines have upper and lower cross-hatched scroll fill zones and bracket elements with negative ovals (Figure 76).

PIGMENT USE AND LOCATION ON VESSEL: none

TYPE AND VARIETY (IF KNOWN): Unidentified fine ware, cf. Barkman Engraved 
SITE NAME OR SITE NUMBER: George T. Wright Collection, Red River County, Texas

VESSEL NO.: GTW-522 [TX 146/1], B. R. R.

VESSEL FORM: Bowl (Figure 77)

NON-PLASTICS AND PASTE: grog

RIM AND LIP FORM: Direct rim and rounded lip

CORE COLOR: F (fired in a reducing environment and cooled in the open air)

INTERIOR SURFACE COLOR: brown; fire clouds on the rim, body, and base

EXTERIOR SURFACE COLOR: brown; fire clouds on the rim and body

WALL THICKNESS (IN MM): rim, 5.7 mm

INTERIOR SURFACE TREATMENT: smoothed

EXTERIOR SURFACE TREATMENT: none

HEIGHT (IN CM): 12.0

ORIFICE DIAMETER (IN CM): 16.8

DIAMETER AT BOTTOM OF RIM OR NECK (IN CM): N/A

BASE DIAMETER (IN CM) AND SHAPE

OF BASE: $10.8 \mathrm{~cm}$, circular and rounded

ESTIMATED VOLUME (IN LITERS): 0.8

DECORATION (INCLUDING MOTIF AND ELEMENTS WHEN APPARENT): The rim has six horizontal incised lines as well as a single broad horizontal incised or grooved line to mark the bottom of the rim. The vessel body has four sets of incised diamond elements divided by two or three intersecting diagonal opposed incised lines and upper and lower nested triangles filled with tool punctations. The incised diamond elements are divided into four triangles filled with either tool punctations or hatched incised triangular zones (Figure 77).

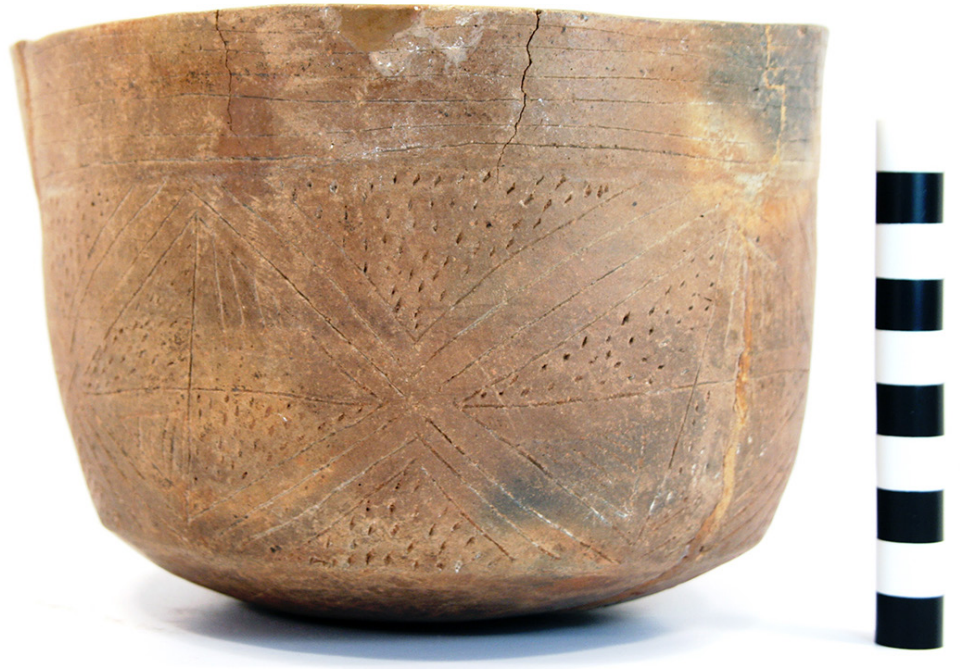

Figure 77. cf. Pennington Punctated-Incised bowl, GTW522.

PIGMENT USE AND LOCATION ON VESSEL: none

TYPE AND VARIETY (IF KNOWN): cf. Pennington Punctated-Incised (see Suhm and Jelks 1962:121) 
SITE NAME OR SITE NUMBER: George T. Wright Collection, Red River County, Texas

VESSEL NO.: GTW-527 [TX 147/1], B. R. R.

VESSEL FORM: Short-necked bottle (Figure 78)

NON-PLASTICS AND PASTE: grog, bone, and hematite

RIM AND LIP FORM: Direct rim and rounded lip

CORE COLOR: A (fired and cooled in an oxidizing environment)

INTERIOR SURFACE COLOR: yellowish-brown

EXTERIOR SURFACE COLOR: yellowish-brown; fire clouds on the rim and body

WALL THICKNESS (IN MM): rim, $5.5 \mathrm{~mm}$

INTERIOR SURFACE TREATMENT: none

EXTERIOR SURFACE TREATMENT: smoothed

HEIGHT (IN CM): 9.8

ORIFICE DIAMETER (IN CM): 4.9

DIAMETER AT BOTTOM OF RIM OR NECK (IN CM): 5.3

BASE DIAMETER (IN CM) AND SHAPE OF BASE: $6.4 \mathrm{~cm}$, circular and rounded

ESTIMATED VOLUME (IN LITERS): 0.3

DECORATION (INCLUDING MOTIF AND ELEMENTS WHEN APPARENT): The vessel section has cross-hatched engraved lines on ca. 30 percent of the vessel body area (Figure 78).

The remainder of the vessel is plain.

PIGMENT USE AND LOCATION ON

VESSEL: none

TYPE AND VARIETY (IF KNOWN):

Unidentified fine ware

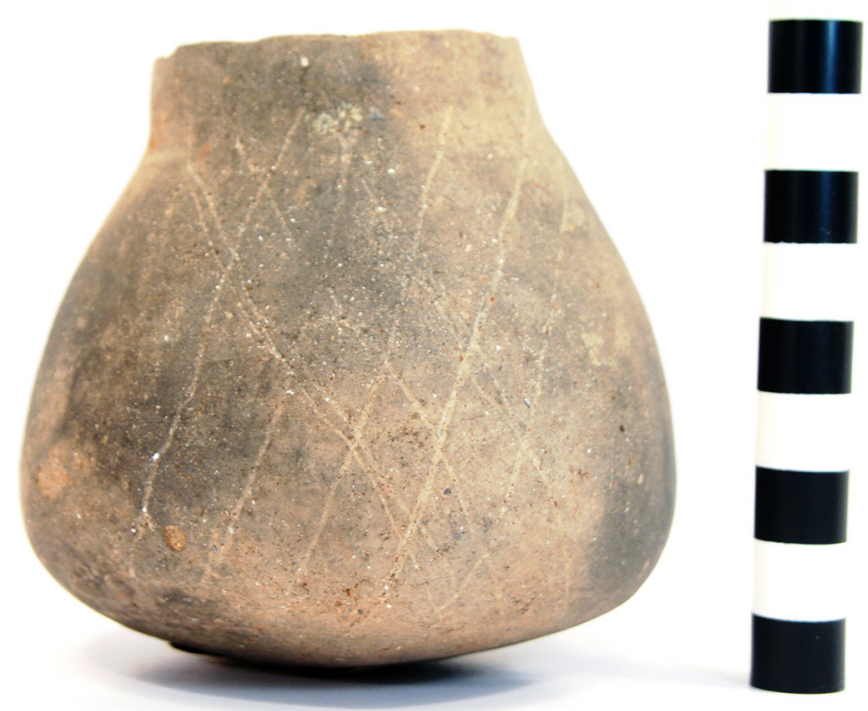

Figure 78. Engraved short-necked bottle, GTW527. 
SITE NAME OR SITE NUMBER: George T. Wright Collection, Lamar County, Texas. Wright's notebook indicates this vessel came from a burial at the Sanders site (41LR2), near but not from either of the two mounds at the site (Jackson et al. 2000; Krieger 1946).

VESSEL NO.: GTW-535 [TX 148/1], Burial Lamar

VESSEL FORM: Bowl with four lip appliqued lugs (Figure 79)

NON-PLASTICS AND PASTE: grog

RIM AND LIP FORM: Inverted rim and rounded lip

CORE COLOR: $\mathrm{G}$ (fired in a reducing environment and cooled in the open air)

INTERIOR SURFACE COLOR: dark grayish-brown

EXTERIOR SURFACE COLOR: reddish-brown; fire clouds on the body

WALL THICKNESS (IN MM): rim, $7.6 \mathrm{~mm}$

INTERIOR SURFACE TREATMENT: smoothed

EXTERIOR SURFACE TREATMENT: burnished

HEIGHT (IN CM): 10.2

ORIFICE DIAMETER (IN CM): 12.5

DIAMETER AT BOTTOM OF RIM OR NECK

(IN CM): 12.3

BASE DIAMETER (IN CM) AND SHAPE OF

BASE: $5.2 \mathrm{~cm}$, circular and flat

ESTIMATED VOLUME (IN LITERS): 0.6

DECORATION (INCLUDING MOTIF AND

ELEMENTS WHEN APPARENT): the rim panel has four sets of vertical and diagonal engraved lines as well as a single horizontal engraved line at the base of the rim panel. The appliqued lugs divide the engraved sets (Figure 79).

PIGMENT USE AND LOCATION ON VESSEL: none

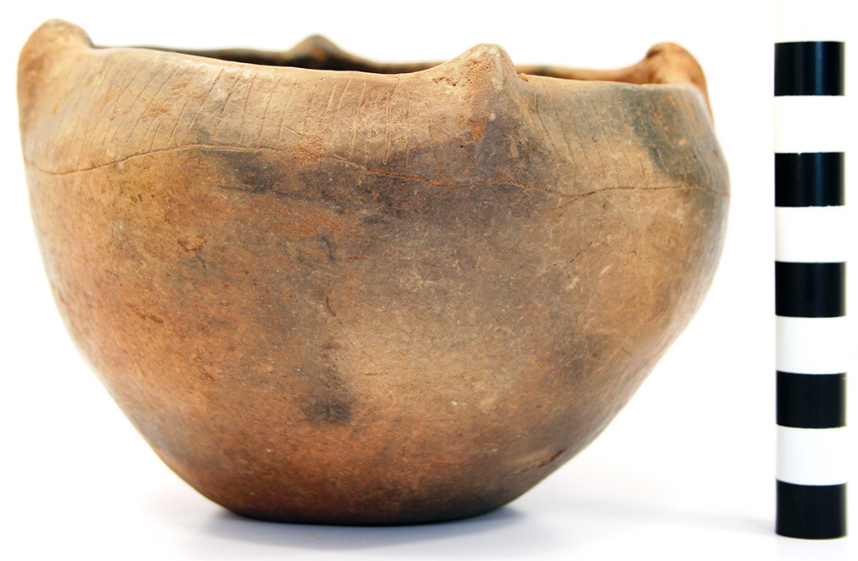

Figure 79. Sanders Engraved bowl, GTW-535.

TYPE AND VARIETY (IF KNOWN): Sanders

Engraved (see Suhm and Jelks 1962:137 and Plate 69) 
SITE NAME OR SITE NUMBER: George T. Wright Collection, Red River County, Texas. Wright's notebook indicates this vessel came from a small mound on Cuthand Creek, the same provenience as GTW-351 and GTW-397.

VESSEL NO.: GTW-537, B. R. R.

VESSEL FORM: Effigy bowl with a hollow body and a broad, flat tail (Figure 80a-c)

NON-PLASTICS AND PASTE: shell

RIM AND LIP FORM: Inverted rim and rounded lip

CORE COLOR: B (fired and cooled in a reducing environment)

INTERIOR SURFACE COLOR: very dark grayish-brown EXTERIOR SURFACE COLOR: very dark grayishbrown

WALL THICKNESS (IN MM): rim, 4.2 mm

INTERIOR SURFACE TREATMENT: none

EXTERIOR SURFACE TREATMENT: burnished

HEIGHT (IN CM): 5.3

ORIFICE DIAMETER (IN CM): 3.9

DIAMETER AT BOTTOM OF RIM OR NECK (IN CM): 4.2

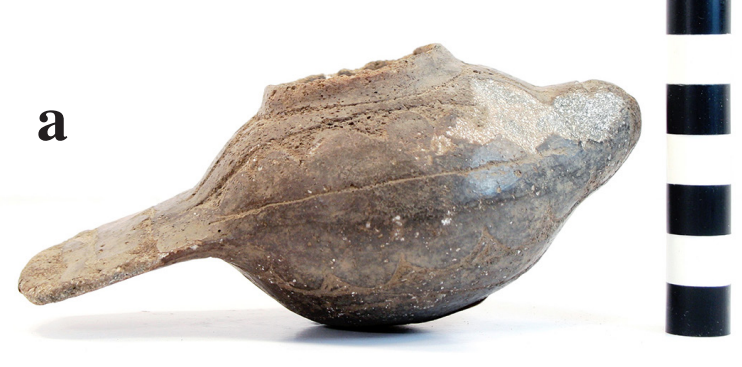

b
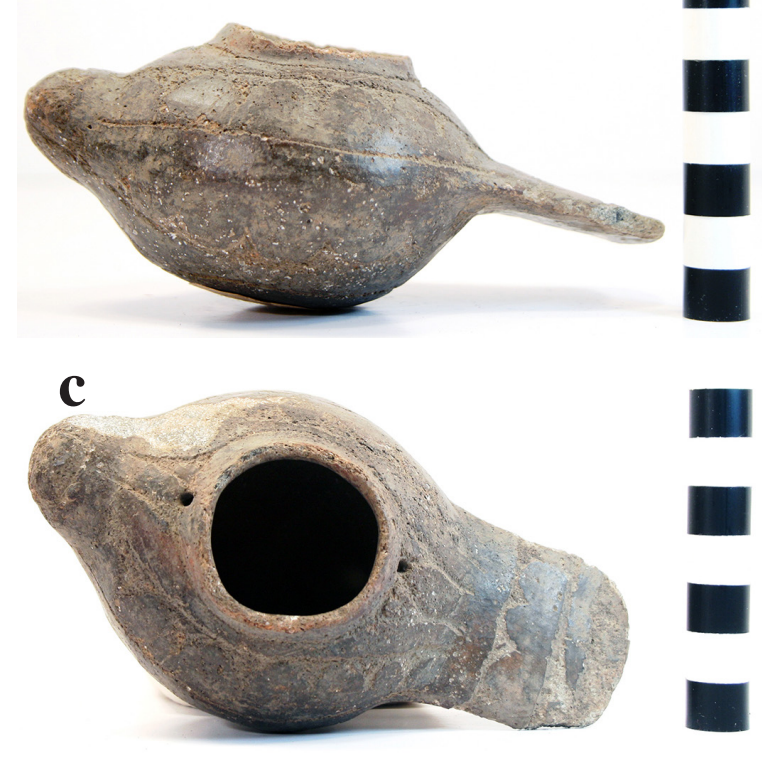

Figure 80. Engraved effigy bowl, GTW-537: a, side view; b, close-up of the bowl; $c$, bowl and effigy tail.

BASE DIAMETER (IN CM) AND SHAPE OF BASE: $4.0 \mathrm{~cm}$, circular and rounded

ESTIMATED VOLUME (IN LITERS): 0.1

DECORATION (INCLUDING MOTIF AND ELEMENTS WHEN APPARENT): The body of the effigy has a single engraved line encircling the vessel opening. There are two sets of two vertical engraved lines pendant from the single curvilinear engraved line, and these extend either towards the effigy head or the broad tail. Small suspension holes (1.2-1.4 mm in diameter) are next to the single curvilinear engraved line and between the two vertical engraved lines. The rounded effigy head (19.0 $\mathrm{mm}$ in height) itself is plain. The effigy bowl itself is $131.0 \mathrm{~mm}$ in length and $72.0 \mathrm{~mm}$ in width. There is a second curvilinear engraved line on the effigy body, and it has a series of excised pendant triangles (Figure 80a-b).

The broad tail of the effigy has two horizontal engraved lines on it. One is unadorned and the other has three excised pendant triangles; these excised pendant triangles are stylistically comparable to the excised pendant triangles on the effigy body (Figure 80c).

PIGMENT USE AND LOCATION ON VESSEL: none

TYPE AND VARIETY (IF KNOWN): Unidentified fine ware 
SITE NAME OR SITE NUMBER: George T. Wright Collection, Red River County, Texas

VESSEL NO.: GTW-541 [TX 150/1], B. R. R.

VESSEL FORM: Carinated bowl (Figure 81)

NON-PLASTICS AND PASTE: shell

RIM AND LIP FORM: Inverted rim and rounded lip

CORE COLOR: F (fired in a reducing environment and cooled in the open air)

INTERIOR SURFACE COLOR: yellowish-brown; fire clouds on the body and base

EXTERIOR SURFACE COLOR: yellowish-brown; fire clouds on the rim, body, and base

WALL THICKNESS (IN MM): rim, 4.6 mm

INTERIOR SURFACE TREATMENT: smoothed

EXTERIOR SURFACE TREATMENT: burnished

HEIGHT (IN CM): 6.1

ORIFICE DIAMETER (IN CM):

12.7

DIAMETER AT BOTTOM OF

RIM OR NECK (IN CM): 14.2

BASE DIAMETER (IN CM)

AND SHAPE OF BASE: $5.4 \mathrm{~cm}$,

circular and rounded

ESTIMATED VOLUME (IN

LITERS): 0.5

DECORATION (INCLUDING

MOTIF AND ELEMENTS

WHEN APPARENT): Plain

(Figure 81)

PIGMENT USE AND

LOCATION ON VESSEL: none

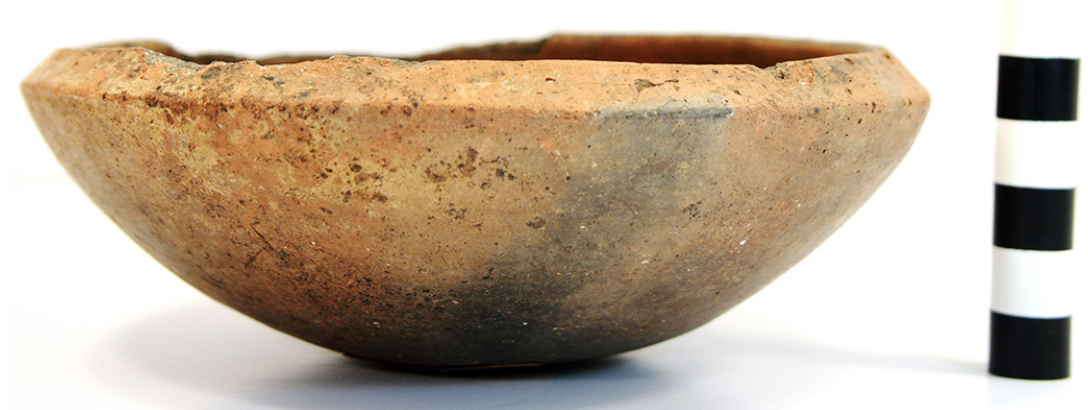

Figure 81. Simms Plain carinated bowl, GTW-541.

TYPE AND VARIETY (IF

KNOWN): Simms Plain 
SITE NAME OR SITE NUMBER: George T. Wright Collection, Red River County, Texas

VESSEL NO.: GTW-548 [TX 151/1], B. R. R.

VESSEL FORM: Carinated bowl (Figure 82)

NON-PLASTICS AND PASTE: shell

RIM AND LIP FORM: Inverted rim and rounded lip

CORE COLOR: B (fired and cooled in a reducing environment)

INTERIOR SURFACE COLOR: dark grayish-brown

EXTERIOR SURFACE COLOR: dark grayish-brown

WALL THICKNESS (IN MM): rim, 4.6 mm

INTERIOR SURFACE TREATMENT: smoothed

EXTERIOR SURFACE TREATMENT: smoothed

HEIGHT (IN CM): 5.9

ORIFICE DIAMETER (IN CM): 8.9

DIAMETER AT BOTTOM OF RIM OR NECK (IN CM): 11.4

BASE DIAMETER (IN CM)

AND SHAPE OF BASE: $4.3 \mathrm{~cm}$, circular and convex

ESTIMATED VOLUME (IN LITERS): 0.3

DECORATION (INCLUDING MOTIF AND ELEMENTS

WHEN APPARENT): Plain, but with a horizontal grooved or depressed area dividing the upper rim panel from the lower rim panel (Figure 82).

PIGMENT USE AND

LOCATION ON VESSEL: none

TYPE AND VARIETY (IF

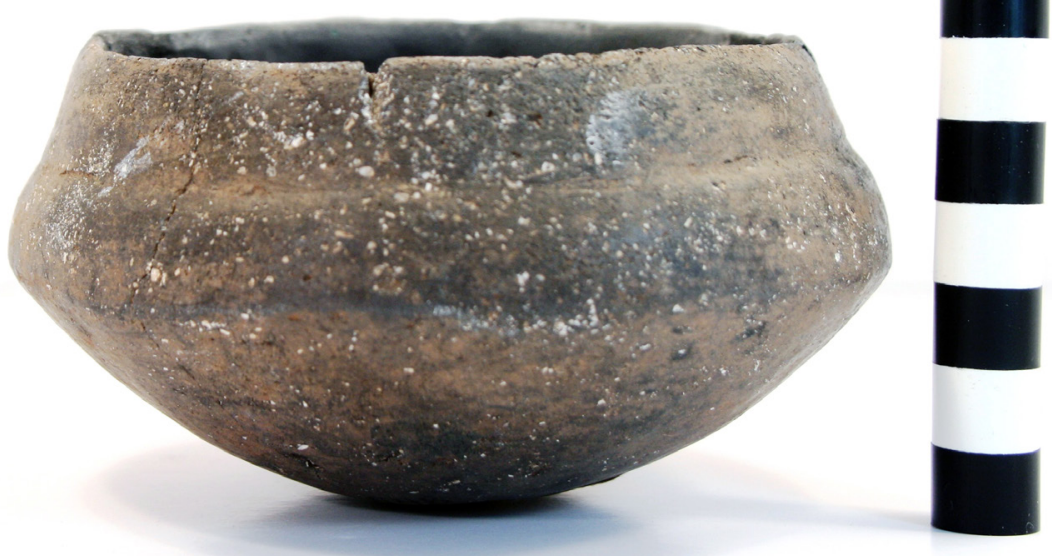

KNOWN): Simms Plain

Figure 82. Simms Plain carinated bowl, GTW-548. 
SITE NAME OR SITE NUMBER: George T. Wright Collection, Red River County, Texas

VESSEL NO.: GTW-550 [TX 152/1], B. R. R.

VESSEL FORM: Carinated bowl (Figure 83a)

NON-PLASTICS AND PASTE: grog

RIM AND LIP FORM: Inverted-direct rim and rounded lip

CORE COLOR: B (fired and cooled in a reducing environment)

INTERIOR SURFACE COLOR: dark grayish-brown

EXTERIOR SURFACE COLOR: dark grayish-brown

WALL THICKNESS (IN MM): rim, 4.9 mm

INTERIOR SURFACE TREATMENT: burnished

EXTERIOR SURFACE TREATMENT: burnished

HEIGHT (IN CM): 7.3

ORIFICE DIAMETER (IN CM): 15.2

DIAMETER AT BOTTOM OF RIM OR NECK

(IN CM): 16.0

BASE DIAMETER (IN CM) AND SHAPE OF

BASE: $7.6 \mathrm{~cm}$, circular and convex

ESTIMATED VOLUME (IN LITERS):

0.7

\section{a}

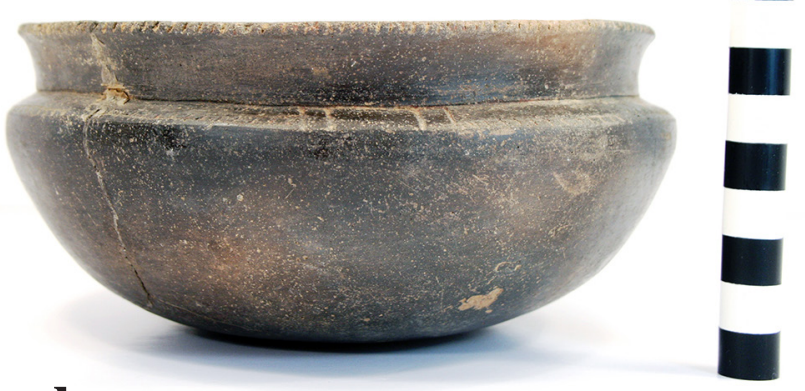

b

lip

DECORATION (INCLUDING

MOTIF AND ELEMENTS WHEN

APPARENT): The upper rim panel is plain, but the lower rim panel has an engraved motif repeated four times around the vessel. The lower rim panel is divided into four sections by two

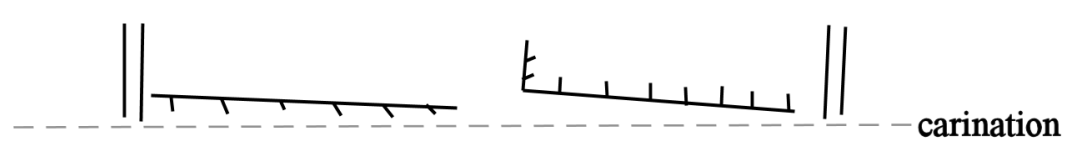

Figure 83. Simms Engraved, var. Darco carinated bowl, GTW550: a, side view; $b$, decorative elements. sets of two vertical engraved lines. Within these sections are discontinuous horizontal and vertical-diagonal engraved lines with either sideways-, upward- or downward-pointing tick marks (Figure 83a-b). The rim has also been notched from right to left on the lip.

PIGMENT USE AND LOCATION ON VESSEL: red pigment in the engraved lines

TYPE AND VARIETY (IF KNOWN): Simms Engraved, var. Darco 
SITE NAME OR SITE NUMBER: George T. Wright Collection, Red River County, Texas

VESSEL NO.: GTW-553 [TX 153/1], B. R. R.

VESSEL FORM: Carinated bowl, hubcap form (Figure 84a)

NON-PLASTICS AND PASTE: shell

RIM AND LIP FORM: Inverted-direct rim and rounded lip

CORE COLOR: F (fired in a reducing environment and cooled in the open air)

INTERIOR SURFACE COLOR: black

EXTERIOR SURFACE COLOR: black

WALL THICKNESS (IN MM): rim, $4.6 \mathrm{~mm}$

$\mathbf{a}$

INTERIOR SURFACE TREATMENT: burnished

EXTERIOR SURFACE TREATMENT: burnished

HEIGHT (IN CM): 7.9

ORIFICE DIAMETER (IN CM): 15.8

DIAMETER AT BOTTOM

OF RIM OR NECK (IN

CM): 17.1

b

BASE DIAMETER (IN CM) AND SHAPE OF

BASE: $7.6 \mathrm{~cm}$, circular and convex

ESTIMATED VOLUME

(IN LITERS): 0.8

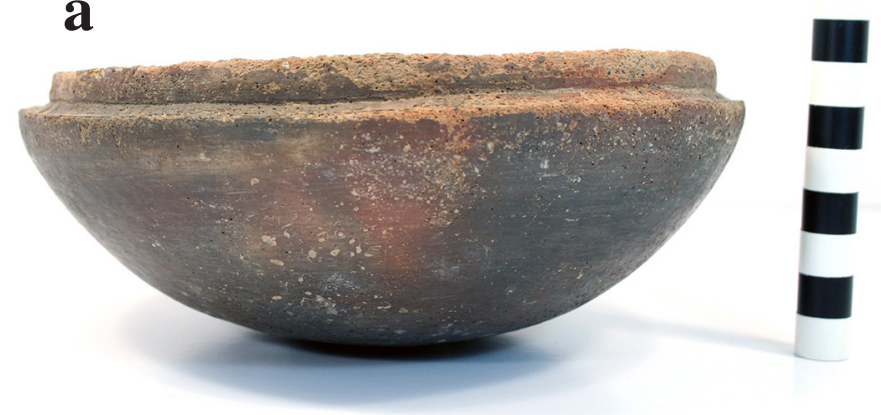

DECORATION (INCLUDING MOTIF AND ELEMENTS WHEN APPARENT): The upper rim panel is plain, but the lower rim panel has an engraved motif repeated four times around the vessel. The lower rim panel is divided into four sections by sets of two vertical engraved lines. Within each section are discontinuous horizontal engraved lines with upward-pointing excised tick marks (Figure 84a-b).

PIGMENT USE AND LOCATION ON VESSEL: none

TYPE AND VARIETY (IF KNOWN): Simms Engraved, var. Darco 


\section{Miscellaneous Ceramic Artifacts}

The first of the two miscellaneous ceramic artifacts in the George T. Wright collection from Red River County, Texas, is a large piece $(43.1+\mathrm{mm}$ in height) of a vessel pedestal leg with a flat base (GTW-1017, TX 224/1, B. R. R.). The $32.0 \mathrm{~mm}$ diameter pedestal leg is from a bone-tempered vessel (Figure 85).

The second miscellaneous ceramic artifact is a shell-tempered vessel effigy head (GTW-1020, TX $226 / 1$, B. R. R.) probably of a canid, with a slotted clay base, probably to fit the effigy head into a hole in an effigy. The head has an engraved open mouth, two eyes, and two upturned ears (Figure 86), and is 25.0 $\mathrm{mm}$ in height and $19.0 \mathrm{~mm}$ in width.

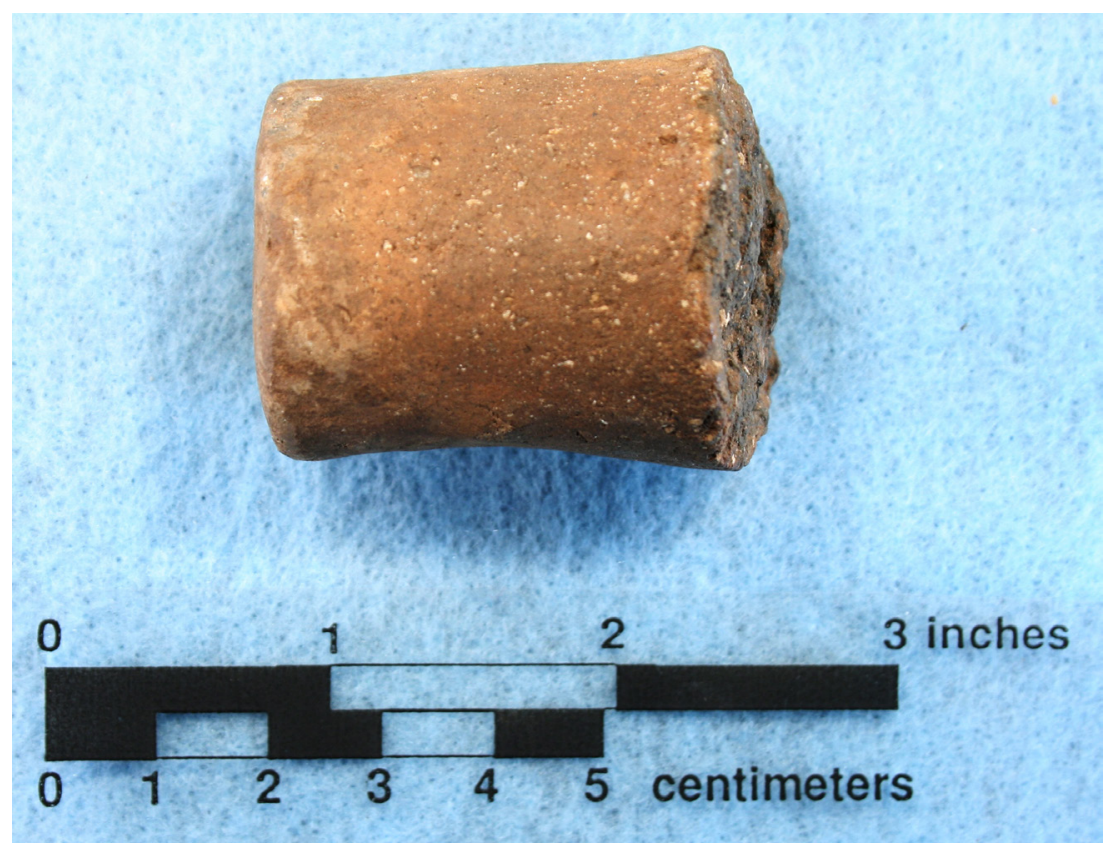

Figure 85. Vessel pedestal leg fragment, GTW-1017.

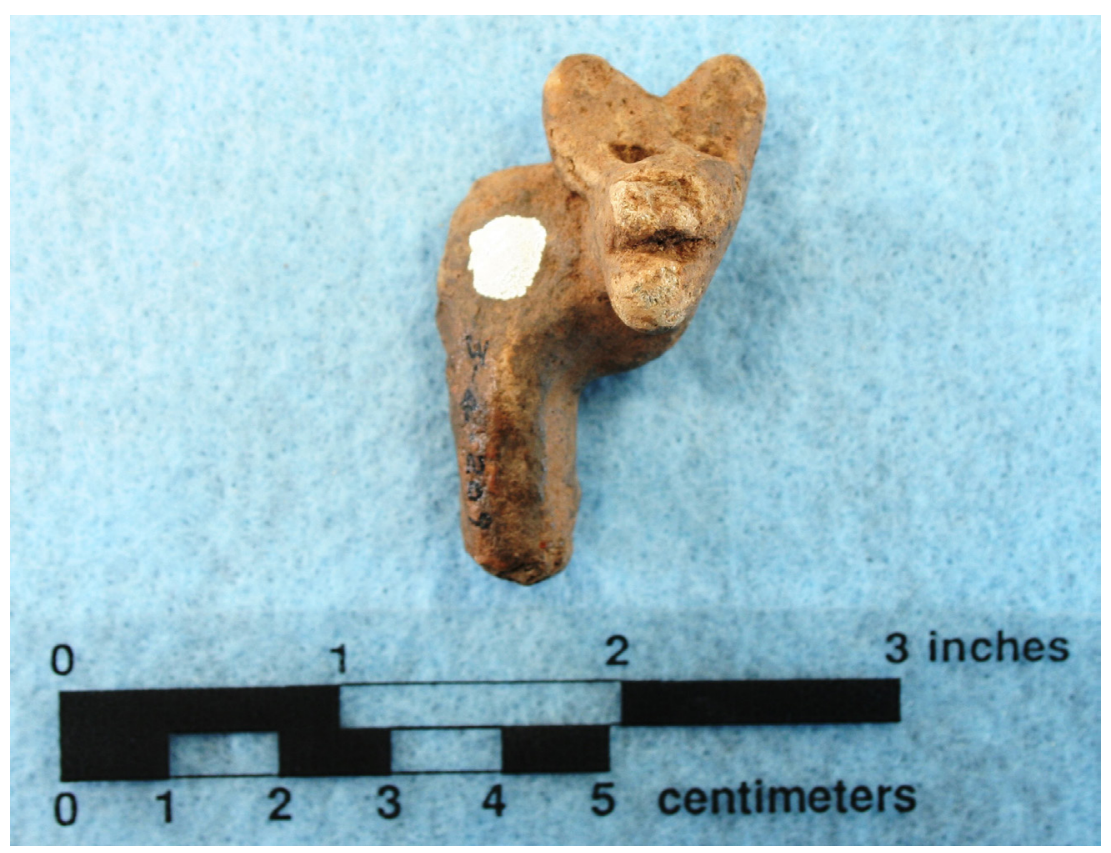

Figure 86. Ceramic dog effigy head, GTW-1020. 


\section{Summary of the George T. Wright Collection Vessel Assemblage from East Texas Sites}

The 85 ceramic vessels in the George T. Wright Collection are from sites in Red River County $(n=82)$, Lamar County $(n=2)$, and Titus County $(n=1)$. Of those vessels from Red River County, 74 are from either the Wright Plantation (41RR7) or Sam Kaufman (41RR16) sites in the Red River basin (likely 24 from the Wright Plantation site and the other 50 from the Sam Kaufman site, excavated by Wright in 1940), and eight others are from several sites in the Sulphur River basin, including one site on Ward's Creek and two others on Cuthand Creek. As best as can be determined from Wright's correspondence with A. T. Jackson about his 1940 excavations at the Sam Kaufman site (see Perttula 2017b), where he mentions specific vessels associated with burial features, information about 30 of the likely 50 vessels he recovered from the site is available, but nothing more specific is available about the other 20 vessels:

- six Hudson Engraved bottles with spool necks;

- one red-slipped Avery Engraved compound bowl;

- one Emory Punctated-Incised jar;

- six Nash Neck Banded jars;

- 16 Simms Engraved carinated bowls; and

- one small "cup" that held a green glauconitic clay pigment

The two vessels from Lamar County sites include a Sanders Engraved vessel from the Middle Caddo period Sanders phase component there (see Jackson et al. 2000; Krieger 1946; Perttula et al. 2016) and a $19^{\text {th }}$ century jar from the northern Rio Grande area of the Southwestern United States, and the one Titus County vessel is a $15-17^{\text {th }}$ century Ripley Engraved, var. Gandy carinated bowl. This vessel was likely made in the Big Cypress Creek basin (see Perttula 2012; Fields et al. 2014) and traded/exchanged with the Late Caddo McCurtain phase community in the Mound Prairie area along the Red River near its confluence with the Kiamichi River (see Figure 1). A single grog-tempered Wilder Engraved bottle from the same Titus phase communities is in the TARL collections from the Wright Plantation site.

The vessels from the Wright Plantation and Sam Kaufman sites can be divided into those tempered with grog $(n=13)$ or those vessels tempered with mussel shell $(n=61)$. The shell-tempered vessels were made by Late Caddo period McCurtain phase potters in the Mound Prairie community (Figure 87), most likely between ca. A.D. 1550-1680, but some of the vessels (i.e., a Keno Trailed, var. Phillips bowl and Simms Engraved, var. Darco carinated bowls) suggest that shell-tempered vessels continued to be made in this area until ca. A.D. 1730; the iron knife blade found in one of the burials by Wright is corroboration for a postA.D. 1680 use of the East Mound at the Sam Kaufman site. So too is the recovery of glass beads in a few of the burials excavated there since the 1950s. The McCurtain phase shell-tempered vessels include fine wares, utility wares, and plain wares (Table 1). 


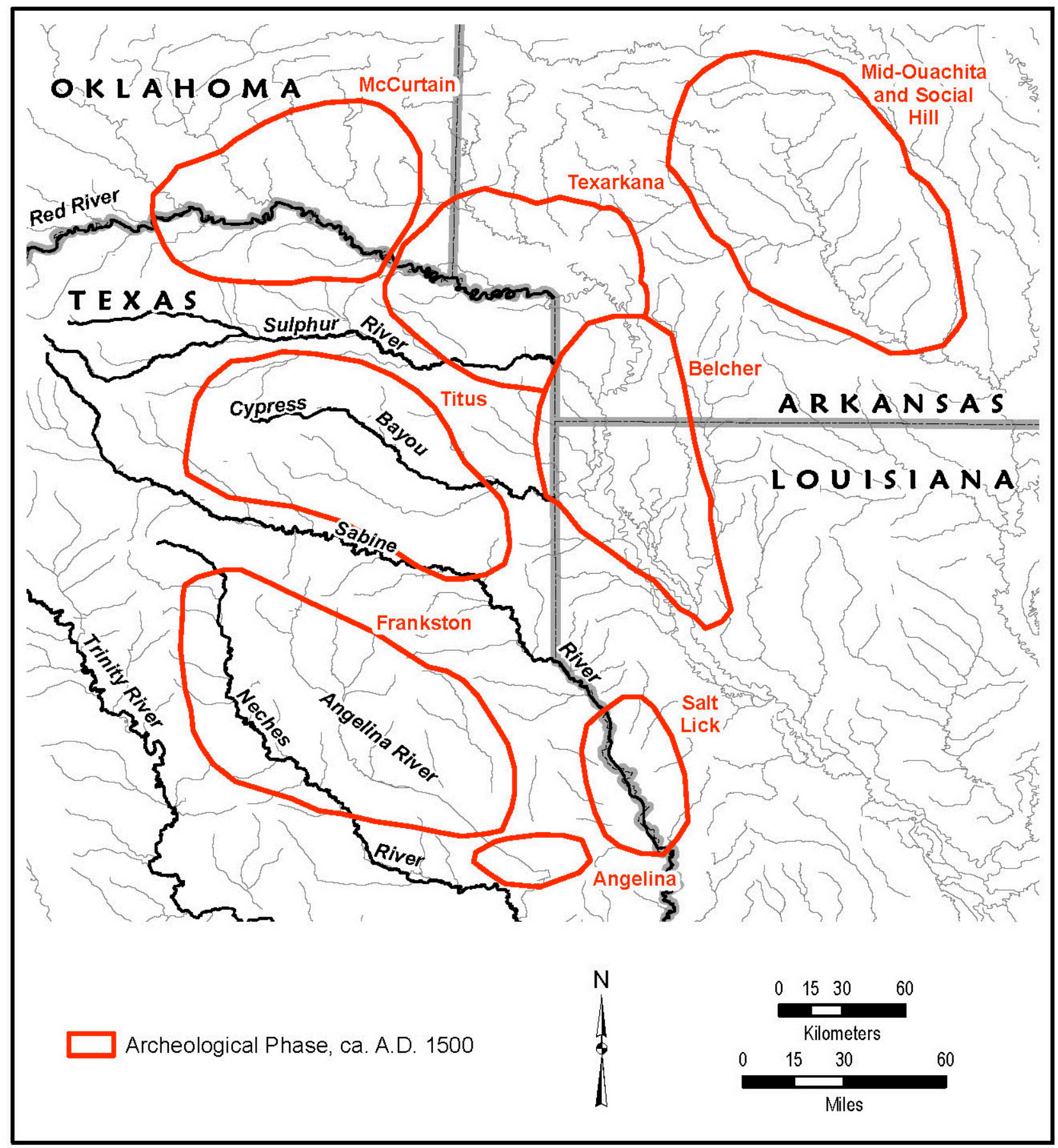

Figure 87. Distribution of Late Caddo period archaeological phases in Arkansas, Louisiana, Oklahoma, and Texas. Figure prepared by Sandra Hannum. 
Table 1. Shell-tempered McCurtain phase vessels from the Wright Plantation and Sam Kaufman sites in the George T. Wright Collection from Red River County, Texas.

\begin{tabular}{|c|c|c|c|c|c|c|c|c|}
\hline \multirow[t]{2}{*}{ Type } & \multicolumn{7}{|c|}{ Vessel Form } & \multirow[b]{2}{*}{$\mathrm{N}$} \\
\hline & $\mathrm{Bt}$ & $\mathrm{Bw}$ & $\mathrm{DB}$ & $\mathrm{Bk}$ & $\mathrm{CB}$ & $\mathrm{CPB}$ & Jar & \\
\hline Avery Engraved & 1 & 1 & 2 & 1 & - & 1 & - & 6 \\
\hline Barkman Engraved & - & 1 & - & - & - & - & - & 1 \\
\hline Hudson Engraved & 7 & - & - & - & - & - & - & 7 \\
\hline Simms Engraved & - & 1 & - & - & 16 & - & - & 17 \\
\hline Taylor Engraved & 3 & - & 3 & - & - & - & - & 6 \\
\hline subtotal, fine ware & 11 & 3 & 5 & 1 & 16 & 1 & - & 37 \\
\hline $\begin{array}{l}\text { Emory Punctated- } \\
\text { Incised }\end{array}$ & - & - & - & - & - & - & 6 & 6 \\
\hline cf. McKinney Plain & - & - & - & - & - & - & 3 & 3 \\
\hline Nash Neck Banded & - & - & - & - & - & - & 9 & 9 \\
\hline $\begin{array}{l}\text { Nash Neck Banded- } \\
\text { Avery Engraved }\end{array}$ & - & - & - & - & - & - & 1 & 1 \\
\hline $\begin{array}{l}\text { Unidentified } \\
\text { appliqued }\end{array}$ & - & - & - & - & - & - & 1 & 1 \\
\hline subtotal, utility ware & - & - & - & - & - & - & 20 & 20 \\
\hline Simms Plain & - & - & - & - & 1 & - & - & 1 \\
\hline Plain bowl & - & 1 & - & - & - & - & - & 1 \\
\hline Plain carinated bowl & - & - & - & - & 1 & - & - & 1 \\
\hline Plain jar & - & - & - & - & - & - & 1 & 1 \\
\hline subtotal, plain ware & - & 1 & - & - & 2 & - & 1 & 4 \\
\hline Totals & 11 & 4 & 5 & 1 & 18 & 1 & 21 & 61 \\
\hline
\end{tabular}

$\mathrm{Bt}=$ bottle; $\mathrm{Bw}=$ bowl; $\mathrm{DB}=$ deep bowl; $\mathrm{Bk}=$ beaker; $\mathrm{CB}=$ carinated bowl; $\mathrm{CPB}=$ compound bowl

The shell-tempered fine ware vessels from the Wright Plantation and Sam Kaufman sites in the George T. Wright Collection comprise 60.7 percent of the assemblage (see Table 1), followed by utility ware (32.8 percent) and plain ware (6.6 percent). The principal fine wares include Simms Engraved carinated bowls, Hudson Engraved spool-necked bottles, Taylor Engraved deep bowls and bottles, as well as Avery Engraved deep bowls, bottles, and a compound bowl, beaker, and rattle bowl. Carinated bowls and bottles are the most common fine ware vessel forms in the vessel assemblage (see Table 1).

The shell-tempered utility ware vessels are primarily of the Nash Neck Banded, Emory PunctatedIncised, and cf. McKinney Plain types (see Table 1). One unique jar has a neck banded rim and the body has an Avery Engraved motif. Other such vessels have been documented from the Rowland Clark site (41RR77, Perino 1994). Another Nash Neck Banded jar has a red-slipped body, but is not otherwise decorated on this part of the vessel. 
The few plain shell-tempered vessels include carinated bowls, bowls, and jars. One of these vessels is a Simms Plain form with its distinctive sharp-angled rim panel, as more commonly seen in Simms Engraved carinated bowls.

The grog-tempered vessels from the Wright Plantation and Sam Kaufman sites are from both preA.D. 1200 and post-A.D. 1600 components. The Early Caddo period vessels from these sites include a Holly Fine Engraved bottle, an East Incised effigy bowl, and a Pennington Punctated-Incised bowl, two plain jars, a plain carinated bowl, and a typologically unidentified engraved bottle. The post-A.D. 1600 grog-tempered vessels from the two sites are represented by a Keno Trailed, var. Phillips bowl, a Hodges Engraved bowl, three Simms Engraved carinated bowls, and a Nash Neck Banded jar. These six vessels likely are intra-regional trade ware that originated in a Texarkana phase community downstream on the Red River (see Figure 87).

The eight vessels from sites in the Sulphur River basin include five vessels with grog or grog-bonehematite temper and three vessels with burned mussel shell temper. The vessels with grog temper include a plain bottle, a vessel with unidentified engraved elements, and three Late Caddo period vessels: an Emory Punctated-Incised jar, a cf. McKinney Plain jar, and a cf. Barkman Engraved carinated bowl. The temper of these vessels suggests they are affiliated with post-A.D. 1400 Texarkana phase components (see Perttula 2015b:84). The shell-tempered vessels from these sites are likely the same age, but may have originated in a different Caddo ceramic tradition. They include an engraved effigy bowl with a hollow body, an Emory Punctated-Incised jar, and a Nash Neck Banded jar.

\section{Comparisons to other nearby Red River County, Texas, Vessel Assemblages}

Compilations of ancestral Caddo vessel assemblages from a number of village sites and cemeteries along the Red River in Red River County, Texas, provide specific information on the stylistic character of the fine wares and utility wares in assemblages of Early Caddo (ca. A.D. 900-1200, Albion phase), Middle Caddo (ca. A.D. 1200-1400, Sanders phase), and Late Caddo (ca. A.D. 1400-1680+, McCurtain phase) age, but also information on the range of vessel forms made by Caddo potters for each of the wares. The compilation discussed below includes 811 vessels, including 18.6 percent from Early Caddo period contents, 12.0 percent from Middle Caddo period contexts, and 69.4 percent from Late Caddo period contexts. These proportions suggest a considerable increase in the ancestral Caddo population of the Red River basin after ca. A.D. 1400, as well as perhaps the increased visibility in modern times of Caddo cemeteries on sites of this age, primarily because of plowing and river channel erosion.

In the Early Caddo period vessel assemblages from Red River County sites, fine wares are most prevalent, particularly Spiro Engraved vessels (Table 2). Utility wares primarily include Crockett Curvilinear Incised, East Incised, and Davis Incised vessels. Plain wares account for 27.8 percent of the Early Caddo ceramic vessels (Table 2). Only a small number of the George T. Wright Collection vessels from Red River sites are of Early Caddo period age, including only a Holly Fine Engraved bottle, an East Incised effigy bowl, and a Pennington Punctated-Incised bowl. A few plain grog-tempered vessels may also be part of the Early Caddo vessel assemblage: two jars and one carinated bowl. 
Table 2. Summary of Early Caddo period Albion phase ceramic vessel assemblages from Red River County, Texas, sites.

\begin{tabular}{|c|c|c|}
\hline Type & No. & Percentage \\
\hline Hickory Engraved & 5 & 3.3 \\
\hline Holly Fine Engraved & 2 & 1.3 \\
\hline Spiro Engraved & 44 & 29.1 \\
\hline Unidentified engraved & 10 & 6.6 \\
\hline Subtotal, fine ware & 61 & 40.4 \\
\hline Canton Incised & 3 & 2.0 \\
\hline Crockett Curvilinear Incised & 15 & 9.9 \\
\hline Davis Incised & 6 & 4.0 \\
\hline East Incised & 11 & 7.3 \\
\hline Kiam Incised & 2 & 2.7 \\
\hline Pennington Punctated-Incised & 3 & 2.0 \\
\hline Pinched & 2 & 1.3 \\
\hline Unidentified incised & 5 & 3.3 \\
\hline Unidentified punctated & 1 & 0.7 \\
\hline Subtotal, utility ware & 48 & 31.8 \\
\hline Paris Plain & 1 & 0.7 \\
\hline Smithport Plain & 1 & 0.7 \\
\hline Williams Plain & 2 & 1.3 \\
\hline Plain bottle & 9 & 6.0 \\
\hline Plain bowl & 2 & 1.3 \\
\hline Plain carinated bowl & 5 & 3.3 \\
\hline Plain jar & 1 & 0.7 \\
\hline Plain, unidentified form* & 21 & 13.9 \\
\hline Subtotal, plain ware & 42 & 27.8 \\
\hline Totals & 151 & 100.0 \\
\hline
\end{tabular}

Sources: Banks and Winters 1975; Perino 1994, 1995; Perttula 1995, 2016a; Skinner et al. 1969 *Perino 1995

Bottles are the most common vessel form in Early Caddo period Albion phase assemblages, accounting for 58 percent of the available vessel sample, in both the fine wares ( 80 percent) and plain wares ( 50 percent), followed by carinated bowls ( 11 percent among the fine wares, 31 percent among the utility wares, and 30 percent among the plain wares); overall 19.7 percent of the vessels of Early Caddo period age are carinated bowls (Table 3 ). Bowls (12.2 percent) and jars (9.9 percent) comprise the remainder of this vessel assemblage. 
Table 3. Vessel forms represented in Albion phase assemblages.

\begin{tabular}{lllll}
\hline Form & Fine ware & Utility ware & Plain ware & N \\
\hline Bottle & 36 & 1 & 10 & 47 \\
Bowl & 2 & 5 & 3 & 10 \\
Carinated bowl & 5 & 5 & 6 & 16 \\
Jar & 2 & 5 & 1 & 8 \\
\hline Totals & 45 & 16 & 20 & 81 \\
\hline
\end{tabular}

Note: Perino's (1995) vessel data from the Holdeman site (4RR11) could not be used because of inconsistencies in vessel form identifications, especially between bowls and carinated bowls, but also because none of the plain ware vessels were identified to form.

The Middle Caddo period Sanders phase vessel assemblage from Red River County sites is dominated by plain wares (Table 4), accounting for more than 71 percent of the vessel sample. Fine ware vessels are primarily Maxey Noded Redware bottles, while utility wares are from Canton Incised jars. There are no Middle Caddo period vessels in the George T. Wright collection from Red River County, Texas, sites, but he did excavate a Sanders Engraved bowl from the Sanders site.

Table 4. Summary of Middle Caddo period Sanders phase ceramic vessel assemblages from Red River County sites.

\begin{tabular}{lcc}
\hline Type & No. & Percentage \\
\hline $\begin{array}{l}\text { Maxey Noded Redware } \\
\text { Sanders Engraved }\end{array}$ & 14 & 14.4 \\
Subtotal, fine ware & 3 & 3.1 \\
Canton Incised & 17 & 17.5 \\
Unidentified Punctated & 10 & 10.3 \\
Subtotal, utility ware & 1 & 1.0 \\
Plain bowl & 11 & 11.3 \\
Plain vessels* & 1 & 1.0 \\
Subtotal, plain ware & 68 & 70.1 \\
\hline Totals & 69 & 71.1 \\
\hline
\end{tabular}

Sources: Harris 1953; Perino 1995; Perttula 1995; Perttula et al. 2012

*form not specified in Perino 1995

Supplemented by vessel data from Middle Caddo period burial features from the Sanders site on the Red River in Lamar County, Texas (see Perttula 2016:Table 3), fine ware vessels are most common (51.4 percent) in the vessel assemblage. These tend to be bottles, bowls, and carinated bowls (Table 5). Utility wares (14.9 percent) are primarily jars, while plain wares (33.8 percent) are mainly bowls and carinated bowls. 
Table 5. Vessel forms represented in Sanders phase assemblages on the Red River in Red River and Lamar Counties, Texas.

\begin{tabular}{|c|c|c|c|c|}
\hline Form & Fine ware & Utility ware & Plain ware & $\mathrm{N}$ \\
\hline \multicolumn{5}{|c|}{ Red River County } \\
\hline Bottle & 2 & - & - & 2 \\
\hline Bowl & - & - & 1 & 1 \\
\hline Jar & - & 1 & 1 & 2 \\
\hline \multicolumn{5}{|l|}{ Lamar County* } \\
\hline Bottle & 18 & - & 3 & 21 \\
\hline Bowl & 8 & 2 & 11 & 21 \\
\hline Carinated bowl & 8 & 2 & 7 & 17 \\
\hline Jar & 2 & 6 & 2 & 10 \\
\hline Totals & 38 & 11 & 25 & 74 \\
\hline
\end{tabular}

*Sanders site (41LR2, Perttula et al. 2016:Table 3)

Note: Perino's (1995) vessel data from the Holdeman site (4RR11) could not be used because of inconsistencies in vessel form identifications, especially between bowls and carinated bowls, but also because none of the plain ware vessels were identified to form.

The Late Caddo period McCurtain phase vessel assemblage is dominated by fine wares (57.4 percent) and utility wares (25.7 percent); plain wares comprise 17.1 percent of the assemblage (Table 6). The majority of the George T. Wright Collection of vessels from sites on the Red River in Red River County are from McCurtain phase contexts; the proportions of fine ware (60.6 percent) and utility ware (32.8 percent) vessels in the collection (see Table 1) are quite comparable to the much larger assemblage of vessels from the Red River basin in Red River County. Plain ware vessels only account for 6.6 percent of the George T. Wright collection, however.

In the larger assemblage of McCurtain phase vessels from Red River basin sites, the fine wares are dominated by Avery Engraved and Simms Engraved vessels, with lesser amounts of Clark Engraved (defined by Perino 1994, 1995, and may be an early variety of Simms Engraved), Hudson Engraved, and Taylor Engraved (see Table 6). In the Wright collection, Simms Engraved (including both shell and grog-tempered vessels) is by far the most common fine ware, suggesting these vessels came from postA.D. 1550 Late McCurtain phase features. Simms Engraved, var. Darco vessels in the Wright collection point to a post-A.D. 1680 use of the Wright Plantation and Sam Kaufman sites. Other common fine ware vessels in the Wright collection include Hudson Engraved, Taylor Engraved, and Avery Engraved (see Table 1). 
Table 6. Summary of Late Caddo period, McCurtain phase ceramic vessel assemblages from Red River County sites.

\begin{tabular}{|c|c|c|}
\hline Type & No. & Percentage \\
\hline Avery Engraved & 136 & 24.2 \\
\hline Bailey Engraved & 3 & 0.5 \\
\hline Bowie Engraved & 13 & 2.3 \\
\hline Clark Engraved & 36 & 6.4 \\
\hline Clement Redware & 11 & 2.0 \\
\hline Hodges Engraved & 4 & 0.7 \\
\hline Hudson Engraved & 25 & 4.4 \\
\hline Keno Trailed & 12 & 2.1 \\
\hline Simms Engraved & 51 & 9.1 \\
\hline Taylor Engraved & 24 & 4.3 \\
\hline $\begin{array}{l}\text { Unidentified appliqued-red } \\
\text { slipped }\end{array}$ & 1 & 0.2 \\
\hline Unidentified engraved & 2 & 0.4 \\
\hline $\begin{array}{l}\text { Unidentified engraved effigy } \\
\text { bottle }\end{array}$ & 1 & 0.2 \\
\hline Unidentified engraved-red-slipped & 1 & 0.2 \\
\hline Unidentified painted & 1 & 0.2 \\
\hline Wilder Engraved & $1 *$ & 0.2 \\
\hline subtotal, fine ware & 322 & 57.4 \\
\hline Emory Punctated-Incised & 53 & 9.4 \\
\hline McKinney Plain & 10 & 1.8 \\
\hline Moore Noded & 2 & 0.4 \\
\hline Nash Neck Banded & 74 & 13.1 \\
\hline Nash Neck Banded-engraved & 1 & 0.2 \\
\hline Unidentified appliqued & 1 & 0.2 \\
\hline Unidentified incised & 1 & 0.2 \\
\hline Unidentified pinched & 3 & 0.5 \\
\hline Subtotal, utility ware & 145 & 25.7 \\
\hline Plain Effigy bowl & 1 & 0.2 \\
\hline Simms Plain & 5 & 0.9 \\
\hline Plain bottle & 14 & 2.5 \\
\hline Plain bowl & 32 & 5.7 \\
\hline Plain carinated bowl & 6 & 1.1 \\
\hline Plain jar & 6 & 1.1 \\
\hline Unidentified plain ware** & 32 & 5.7 \\
\hline Subtotal, plain ware & 96 & 17.1 \\
\hline Totals & 563 & 100.0 \\
\hline
\end{tabular}

Sources: Banks and Banks 2002; Banks and Winters 1975; Cobb 1983; Harris et al. 1954; Harris and Wilson 1956; Huff 1960; Perino 1983, 1994, 1995; Perttula et al. 2012; Perttula 1995, 2008, 2016a, 2016b, 2017a; Skinner et al. 1969

*trade ware from a Titus phase community

***ain ware form not specified by Perino (1995) 
Utility wares in the lager sample of McCurtain phase vessels are dominated by Nash Neck Banded and Emory Punctated-Incised jars (see Table 6), with a few McKinney Plain and Moore Noded vessels. Nash Neck Banded, Emory Punctated-Incised, and cf. McKinney Plain jars are the most common shelltempered utility wares in the George T. Wright collection (see Table 1).

Bowls and bottles are the principal vessel forms in the McCurtain phase vessel assemblage (see Table 6). The shell-tempered plain wares in the George T. Wright collection include a plain jar, two plain carinated bowls, and a plain bowl. One of the plain carinated bowls has been classified as Simms Plain; Perino (1994) identified five Simms Plain vessels in the large McCurtain phase vessel assemblage $(n=202)$ at the Rowland Clark site.

The diversity of vessel forms is impressive in the McCurtain phase vessel assemblages, particularly in the fine wares (Table 7). Fine wares are principally bottles (30.8 percent), carinated bowls (26.9 percent), and deep bowls (25.8 percent), but there are also fine ware bowls ( 8.3 percent), compound bowls ( 7.7 percent), and a jar ( 0.5 percent). In the George T. Wright vessel collection, the fine wares include mainly carinated bowls (43.2 percent), bottles (29.7 percent), and deep bowls (13.5 percent). There are only a few bowls or compound bowls in the Wright collection (see Table 1).

Table 7. Vessel forms represented in McCurtain phase assemblages in the Red River basin in Red River County, Texas.

\begin{tabular}{lllll}
\hline Form & Fine ware & Utility ware & Plain ware & N \\
\hline Bottle & 56 & - & 8 & 64 \\
Bowl & 15 & 2 & 4 & 21 \\
Carinated bowl & 49 & - & 5 & 54 \\
Compound bowl & 14 & - & - & 47 \\
Deep bowl & 47 & - & 2 & 87 \\
Jar & 1 & 84 & 19 & 287 \\
\hline & & & \\
Totals & 182 &
\end{tabular}

The utility wares are almost all jars (see Table 7), while 100 percent of the shell-tempered utility ware vessels in the Wright collection are jars (see Table 1). McCurtain phase vessel assemblages include plain bottles, carinated bowls, bowls, and jars (see Table 7). The George T. Wright Collection of McCurtain phase vessels differs in that there are no plain ware bottles, but only carinated bowls, bowls, and jars (see Table 1). 


\section{Ceramic Pipes}

There are both long-stemmed and elbow ceramic pipes and pipe sherds in the George T. Wright Collection. The long-stemmed Red River style pipe stem sherds are from the surface of Red River County sites (GTW-1004, TX 221/1, S. R. R.), and are from bone-tempered $(n=3)$ and grog-tempered $(\mathrm{n}=1)$ pipe stems (Figure 88). Stem diameters that range from 7.3-10.2 mm are consistent with the Graves Chapel variety of Red River pipe (Hoffman 1967:9), and likely these long-stemmed pipes date from ca. A.D. 1000-1200, the Albion phase of the Early Caddo period.

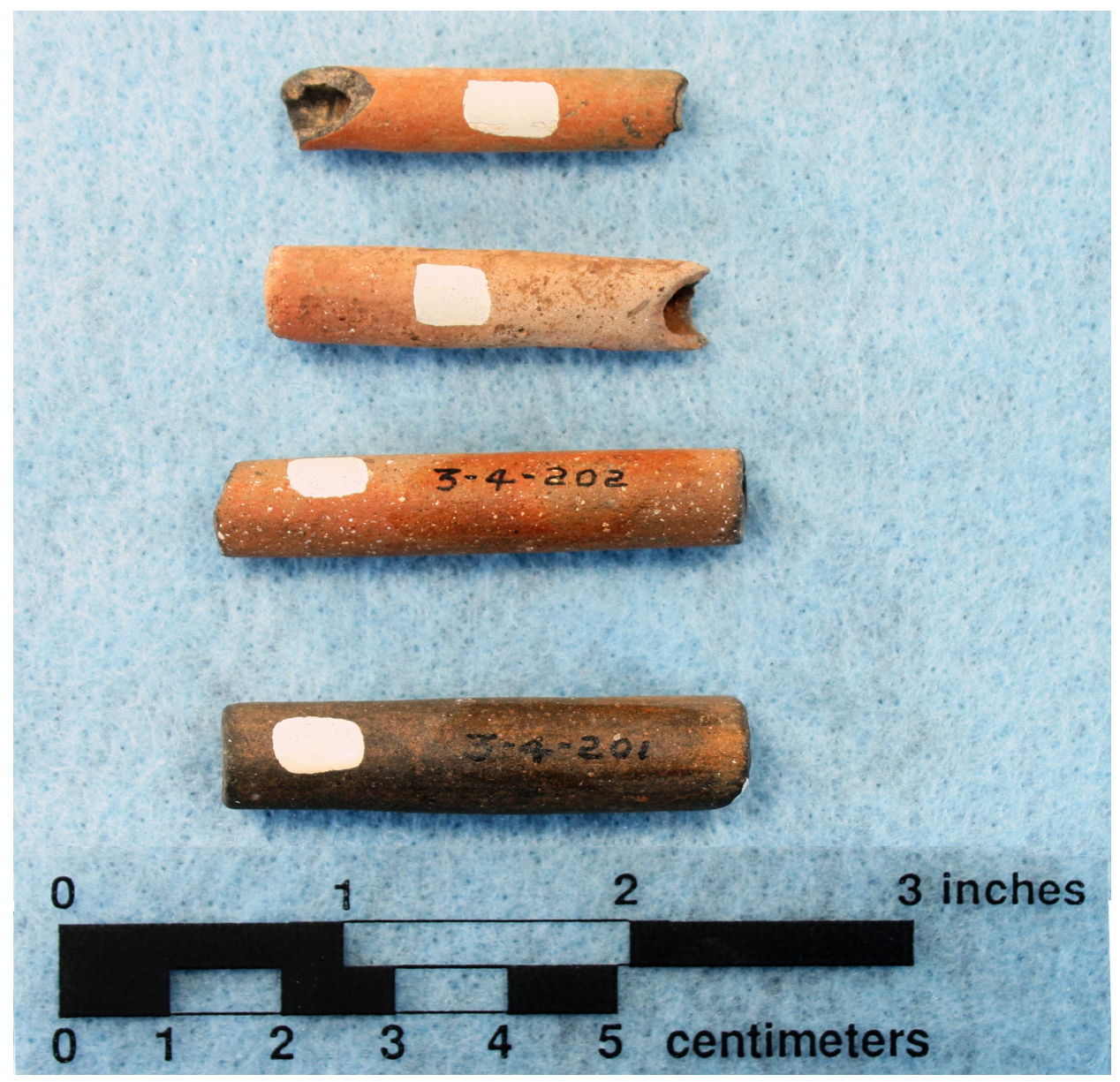

Figure 88. Long-stemmed pipe stem sherds, GTW-1004.

The five elbow pipes, four biconical and one L-shaped, in the collection are from Red River County sites, most likely from the Wright Plantation (41RR7) and Sam Kaufman (41RR16) sites. Such pipes were made and used by the Caddo living on the Red River after ca. A.D. 1300 and into the $18^{\text {th }}$ century A.D. (see Hoffman 1967).

Three of the pipes are from surface contexts and the other two are from burial features; Wright did mention in 1941 correspondence with A. T. Jackson that he did recover a ceramic pipe from one of the burial features he excavated in the East Mound at Sam Kaufman (Perttula 2017b). The first of the pipes from surface contexts (GTW-1039, TX 232/1, S. R. R.) is from a site described in Wright's notebook as being near Manchester, Texas, which suggests it is from the nearby Wright Plantation site. It is a simple exterior burnished grog-tempered biconical elbow pipe with a rounded shoulder, flat lips on the stem 
and bowl, and broad bowl and stem orifice diameters (Figure 89); a single straight engraved line is on the stem lip. The pipe is $37.5 \mathrm{~mm}$ in height and $40.5 \mathrm{~mm}$ in length; the bowl thickness is $5.2 \mathrm{~mm}$ and the stem thickness is $8.2 \mathrm{~mm}$. Elbow pipes of similar form have been reported by Harris (1953:Plate 4:8), Skinner et al. (1969:Figure 24c), Perino (1983:Figure 19d), and Perttula (2008:Figure 47b) from the Sam Kaufman site.

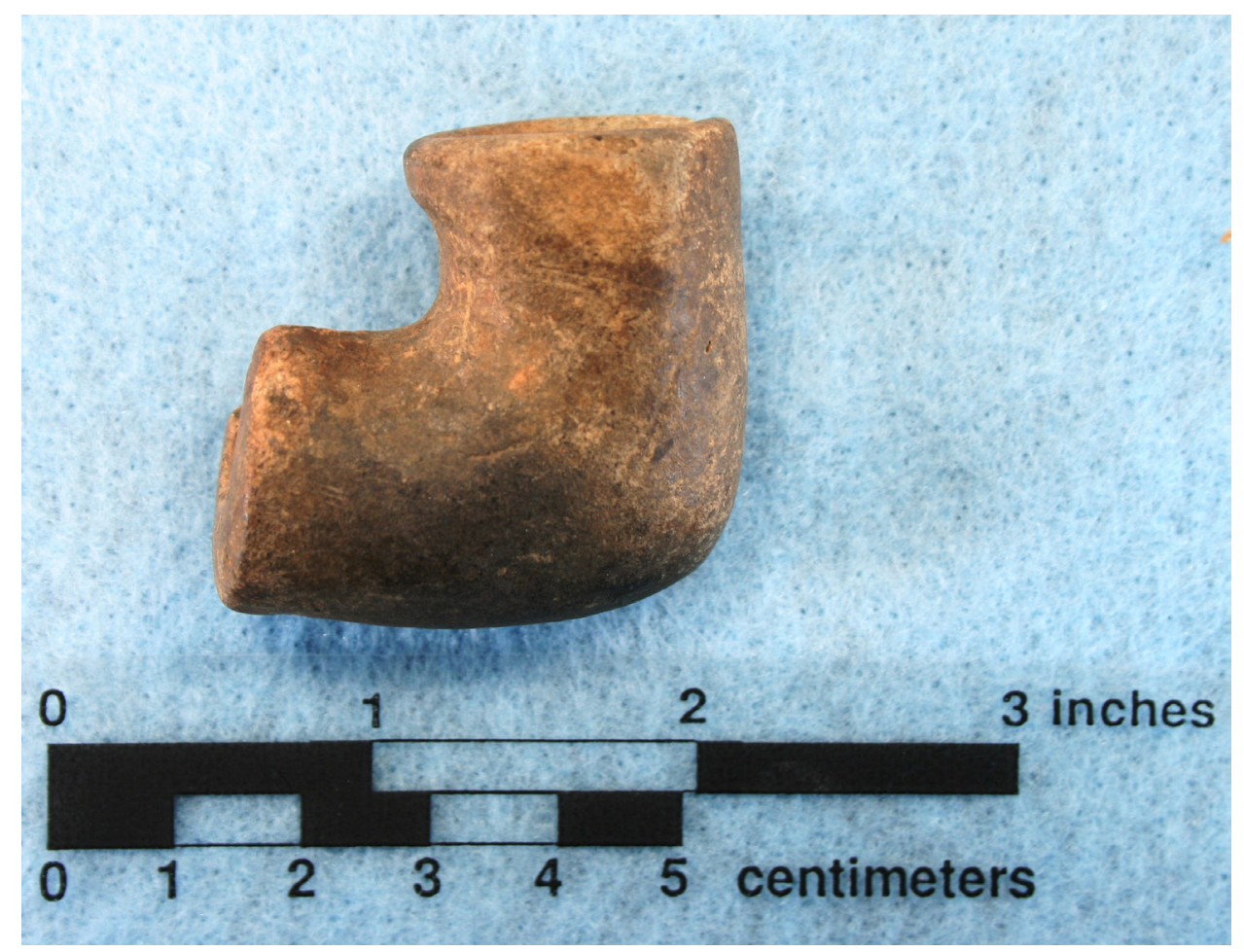

Figure 89. Ceramic elbow pipe, GTW-1039.

The second biconical elbow pipe (GTW-1038, TX 231/1, S. R. R.) from surface contexts at a Red River County site is shell-tempered and was fired and cooled in a reducing environment. It also has a broad bowl (31.2 $\mathrm{mm}$ orifice diameter) and stem (20.3 $\mathrm{mm}$ in diameter), both with flat lips, but the shoulder is a near right-angle. The stem is $5.4 \mathrm{~mm}$ in thickness, and the bowl is $4.7 \mathrm{~mm}$ thick. The lip of the bowl has been lip notched from right to left, and there are engraved elements on both the bowl and the lower stem. The engraved elements on the bowl include upper and lower horizontal engraved lines, with open pendant triangles on the upper horizontal line. On the lower stem and shoulder area, the engraved lines consist of a series of four concentric curvilinear engraved lines (Figure 90a-b).

The third elbow pipe from a surface context (GTW-1023, TX 227/1, S. R. R.) is a grog-tempered elbow pipe stem fragment. The stem is $29.0 \mathrm{~mm}$ in orifice diameter, and $7.1 \mathrm{~mm}$ in thickness, and it has two lower ear-shaped extensions on the lower part of the stem, below the stem hole. The elbow pipe stem also has two horizontal engraved lines below the lip as well as an oval-shaped zone farther down the stem that is filled with cross-hatched engraved lines (Figure 91a-b). Perino (1983:Figure 19b) recovered a keeled elbow pipe from the Bob Williams part of the Sam Kaufman site that had a similar cross-hatched engraved decoration on the stem. 


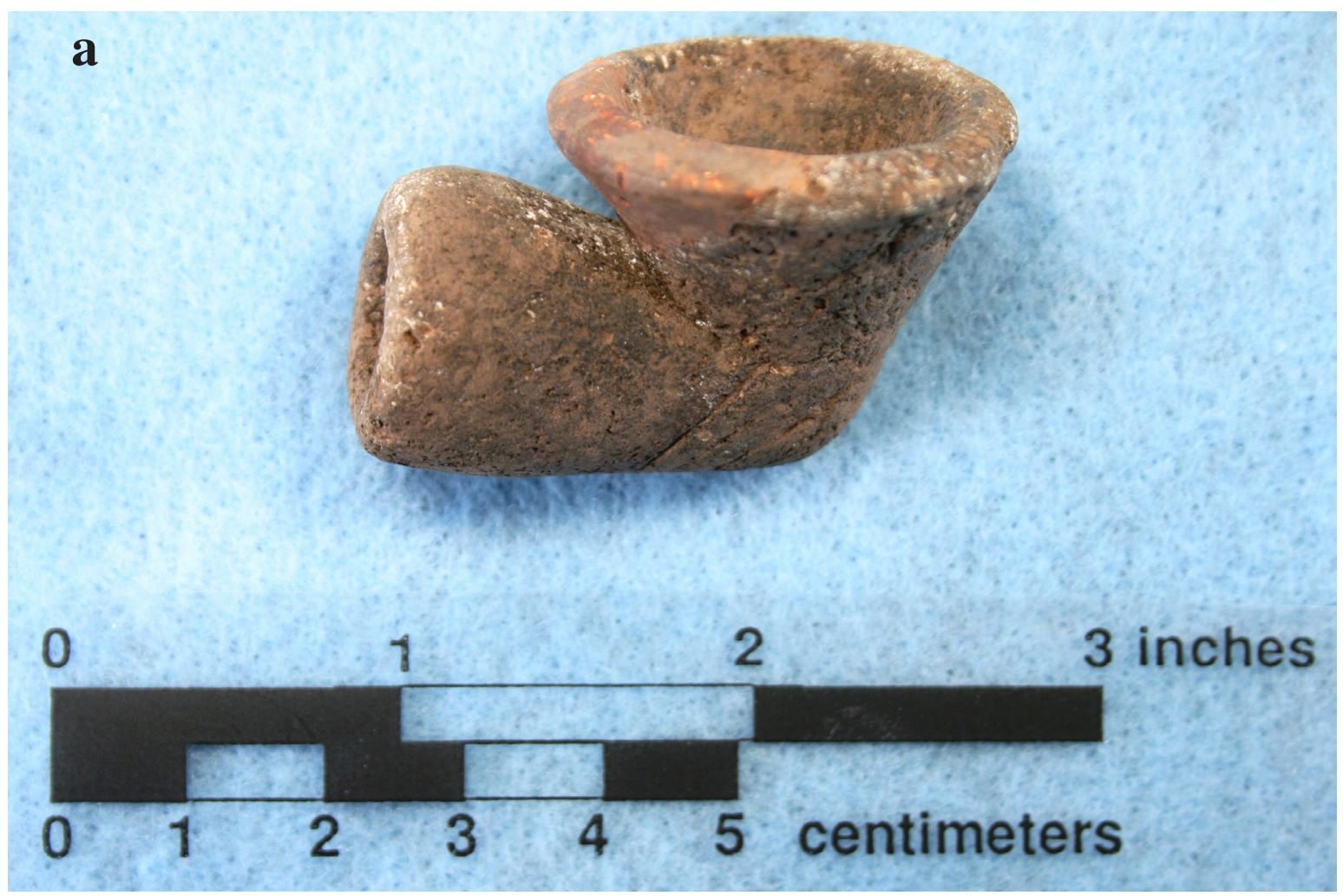

b
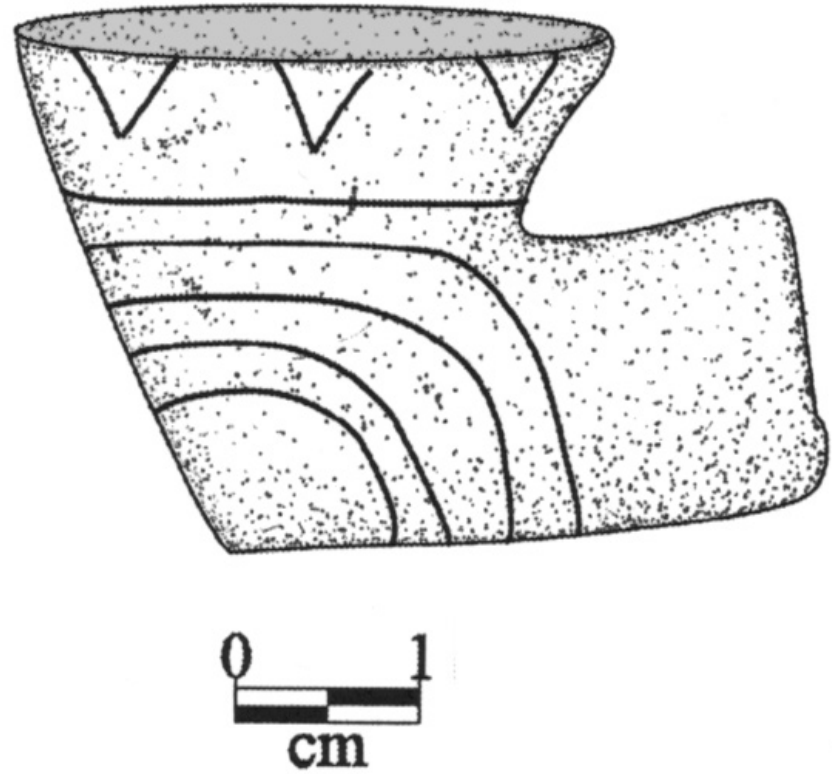

Figure 90. Engraved ceramic elbow pipe, GTW-1038: a, side view; b, decorative elements. 

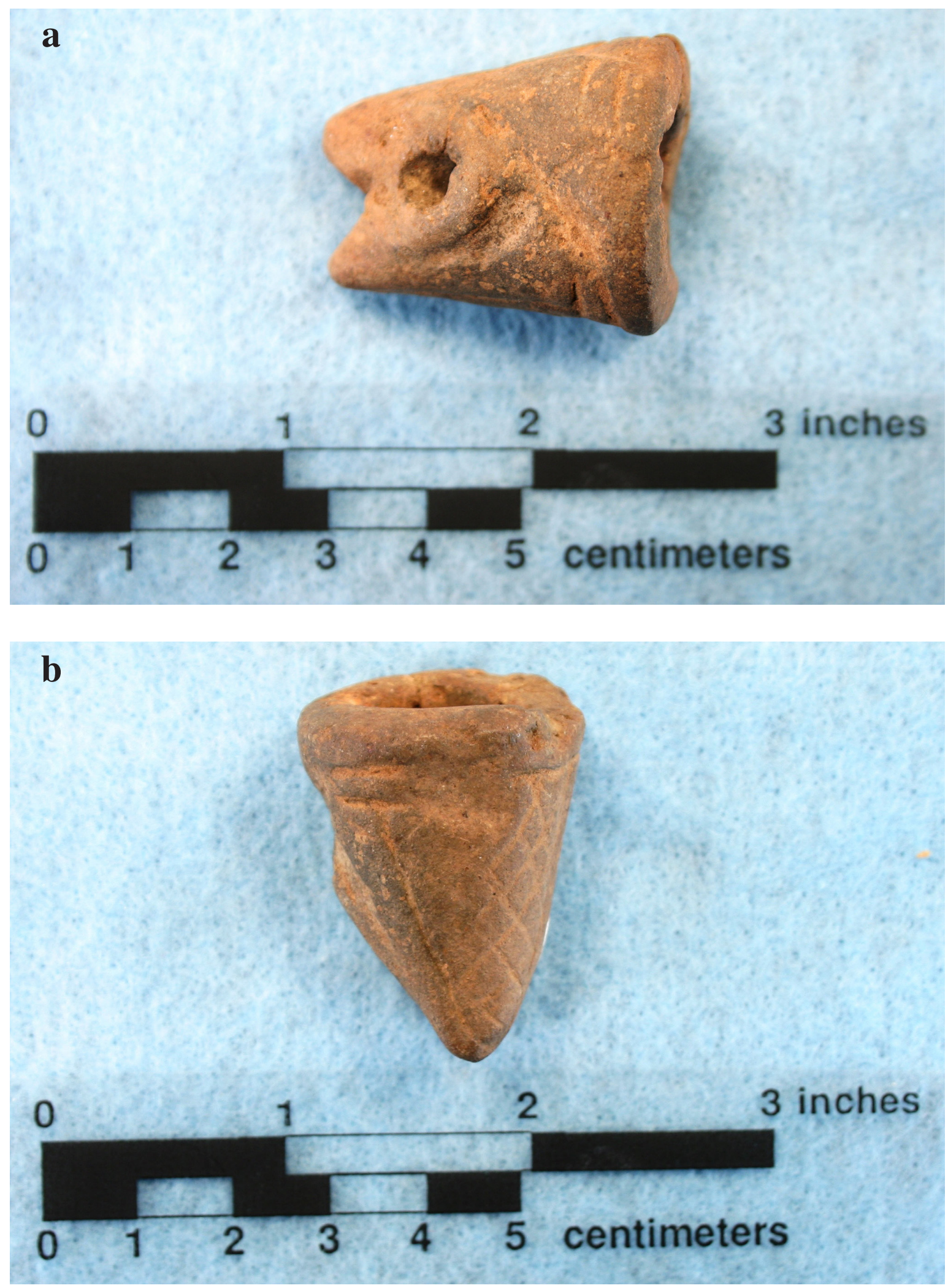

Figure 91. Engraved elbow pipe stem, GTW-1023: a, engraved lines near the lip; b, crosshatched engraved zone. 
One of the two elbow pipes from a burial feature in the George T. Wright collection is a shelltempered L-shaped pipe (GTW-1032, TX 230/1, B. R. R.). The pipe was fired and cooled in an oxidizing environment and has been smoothed on its exterior surface. There are two horizontal engraved lines on the stem (Figure 92). This pipe is $77.0 \mathrm{~mm}$ in length, with a $31.8+\mathrm{mm}$ bowl height (an unknown portion of the bowl has been broken off the pipe). The orifice diameter of the bowl is $21.1 \mathrm{~mm}$, while the stem diameter is $24.0 \mathrm{~mm}$.

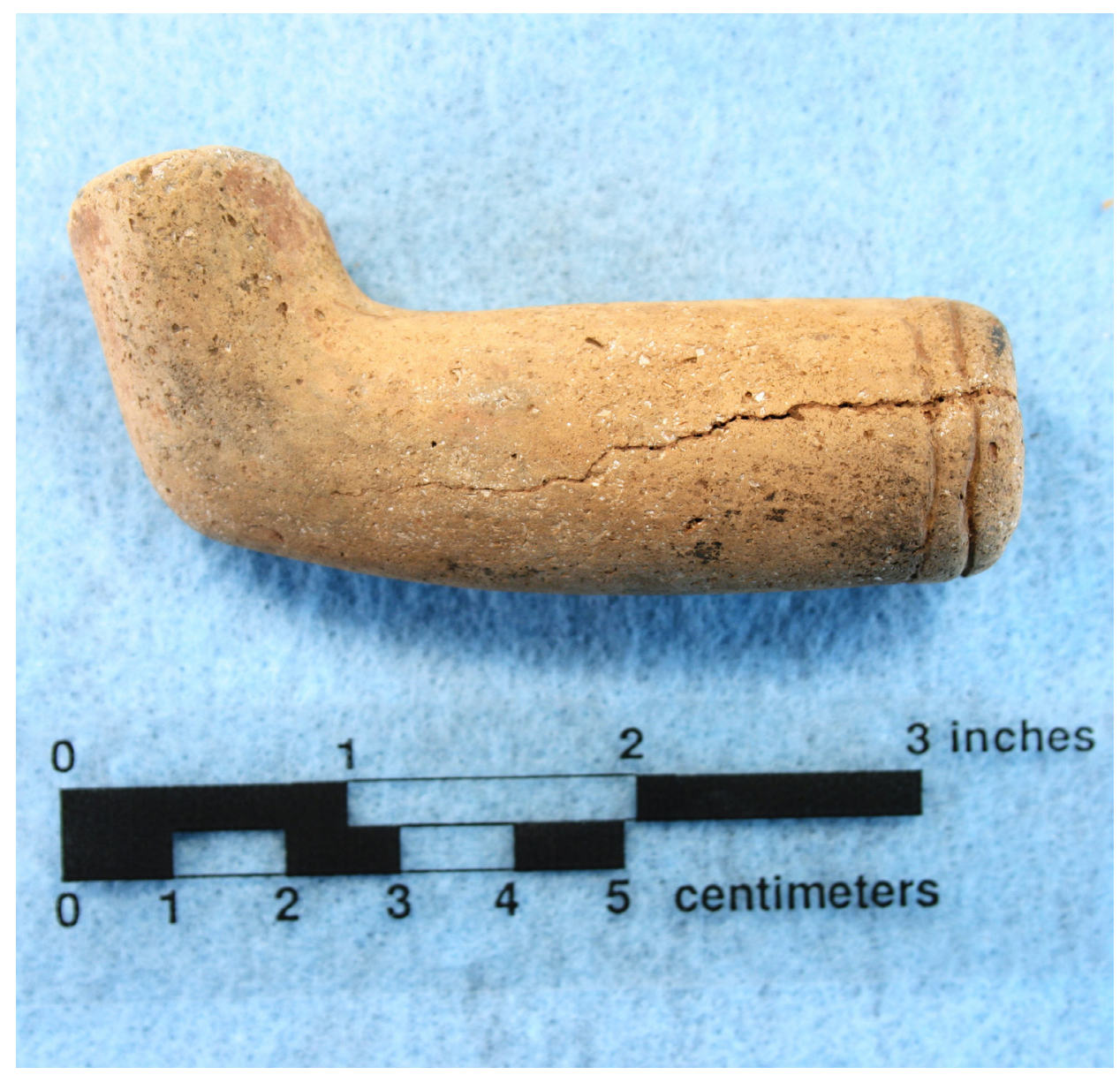

Figure 92. Engraved L-shaped ceramic elbow pipe, GTW-1032.

The second of the two elbow pipes (GTW-1031, TX 229/1, B. R. R.) from a burial feature context (likely from the Sam Kaufman site) in the George T. Wright collection is a fragment of a keeled elbow pipe (i.e., where that portion of the stem that extended past the bowl was folded up against it while the clay was still plastic) (see Todd and Turner 2010; Turner 1978:71). The bowl is intact, and has a rounded lip, but an unknown portion of the stem has been broken away. It is a grog-tempered pipe that was fired and cooled in a reducing environment, and burnished on its exterior surface. The bowl height is $30.2 \mathrm{~mm}$, the orifice diameter of the bowl is $37.7 \mathrm{~mm}$, and the stem diameter near its intersection with the bowl is $14.0 \mathrm{~mm}$. The lower part of the stem has a deliberately raised or non-smoothed area that is covered with rows of small circular punctations (Figure 93a-b). Keeled elbow pipes were manufactured along the Red River between ca. A.D. 1400-1700 (Jesse Todd, July 2017 personal communication). 
$\mathbf{a}$

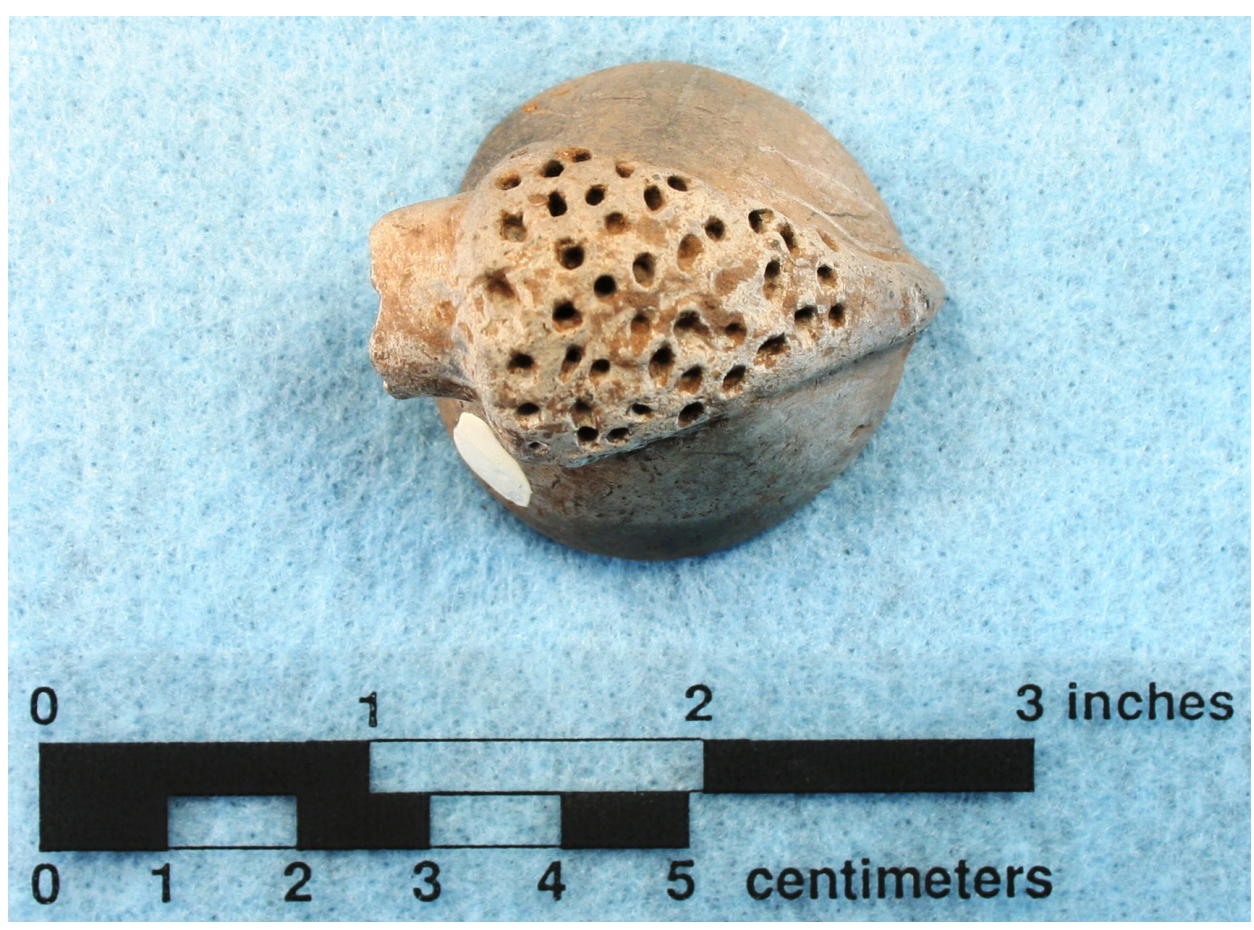

b

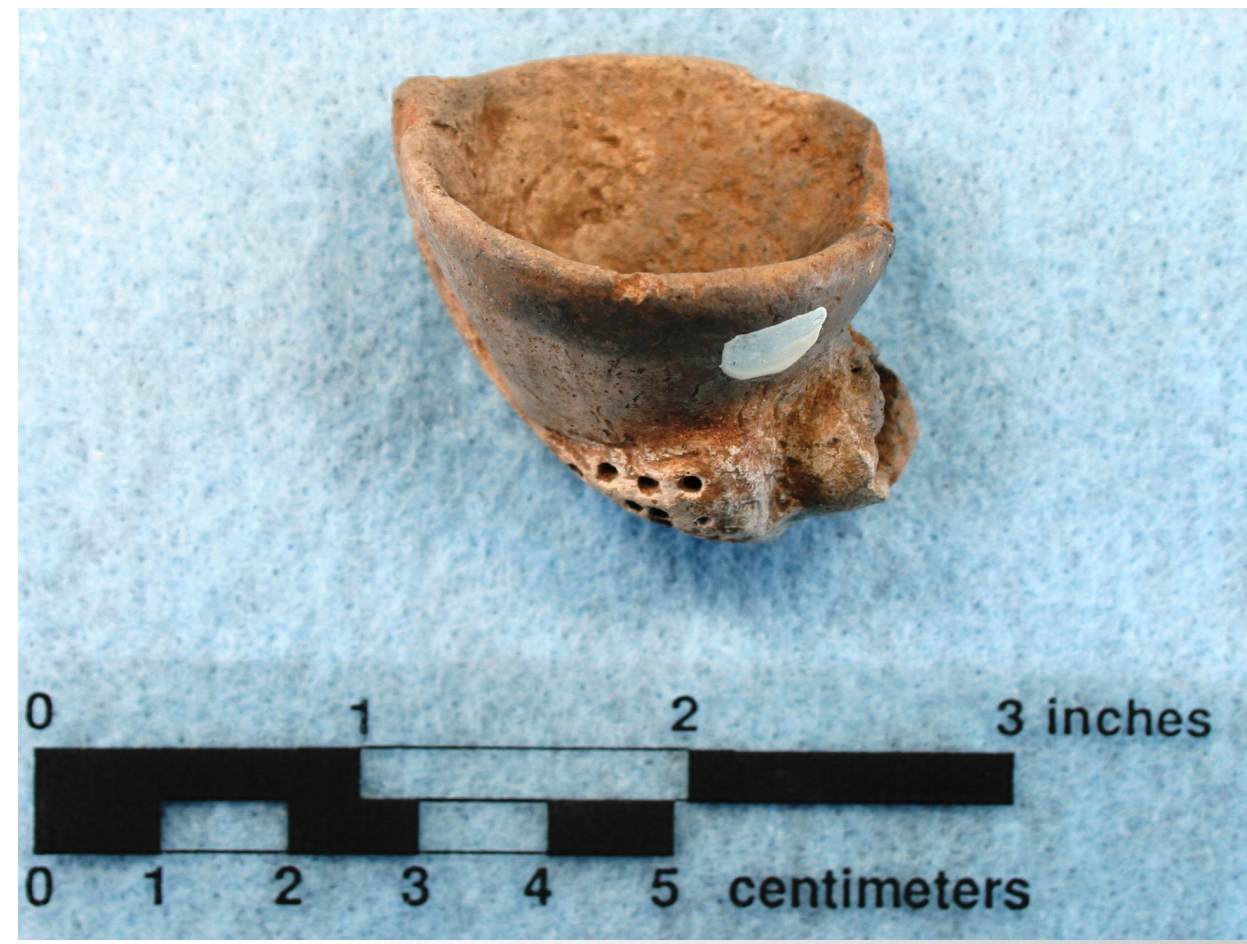

Figure 93. Punctated keeled elbow pipe, GTW-1031: a, raised area with circular punctations; b, elbow pipe bowl and raised area with punctations. 


\section{Arrow points}

A variety of arrow point types made from several different kinds of lithic raw materials are represented in the George T. Wright collection from Red River County sites (Table 8). They are all from surface contexts, again most likely collected from the Wright Plantation and Sam Kaufman sites.

Table 8. Raw materials represented in the arrow points from Red River County, Texas, in the George T. Wright collection.

\begin{tabular}{llllll}
\hline Type & RR chert & RR jasper & Novaculite & QTZ & N \\
\hline Triangular forms* & 21 & 5 & 1 & 2 & 29 \\
Harrell & 1 & 1 & 1 & - & 3 \\
Massard & 3 & 3 & - & - & 6 \\
Hayes & - & - & 1 & - & 1 \\
Homan & - & 1 & - & - & 1 \\
Alba & 4 & - & 1 & - & 5 \\
Catahoula & 2 & - & - & - & 2 \\
Scallorn & 2 & 1 & - & 3 & 4 \\
\hline Totals & 33 & 11 & 4 & & 51 \\
\hline
\end{tabular}

RR=Red River; QTZ=quartzite

*Maud and Talco

About 94 percent of the arrow points are manufactured from cherts (64.7 percent), jasper (21.5 percent), and novaculite (7.8 percent) raw materials available in Red River gravels (see Banks 1990); these materials ultimately originated in the Ouachita Mountains of southeastern Oklahoma (Banks 1990:33-46); jasper is particularly common among the Late Caddo period McCurtain phase Massard and triangular arrow points in the sample (see Table 8). The quartzite raw materials represented in the arrow point samples includes both Uvalde or Ogallala quartzite $(n=2$, red heat-treated and fine-grained) and Stanley and Jackfork formation quartzites ( $\mathrm{n}=1$, gray quartzite) from the Ouachita Mountains (Banks 1990:41-42, 56-57). Banks (1990:56-57) has noted Uvalde quartzites "along the divide between the Red and Sulphur rivers in northeast Texas.... and along the divide between the Sulphur and its principal southern tributary, White Oak Bayou."

The earliest arrow points in the George T. Wright collection are the Catahoula (Figure 94e, g) and Scallorn points (Figure 95a, d-f), both types of which date to the late Woodland period in East Texas (ca. A.D. 700-800) (see Shafer and Walters 2010; Turner et al. 2011). These points are made primarily from Red River cherts (67 percent) (see Table 8).

The next temporal cluster of arrow points $(n=6)$ are the Homan (see Figure 95c) and Alba (see Figure $94 \mathrm{a}-\mathrm{c}, \mathrm{f}$ ) points, both forms dating to the Early Caddo period. Sixty-seven percent of these points are made from Red River chert gravels (see Table 8). 


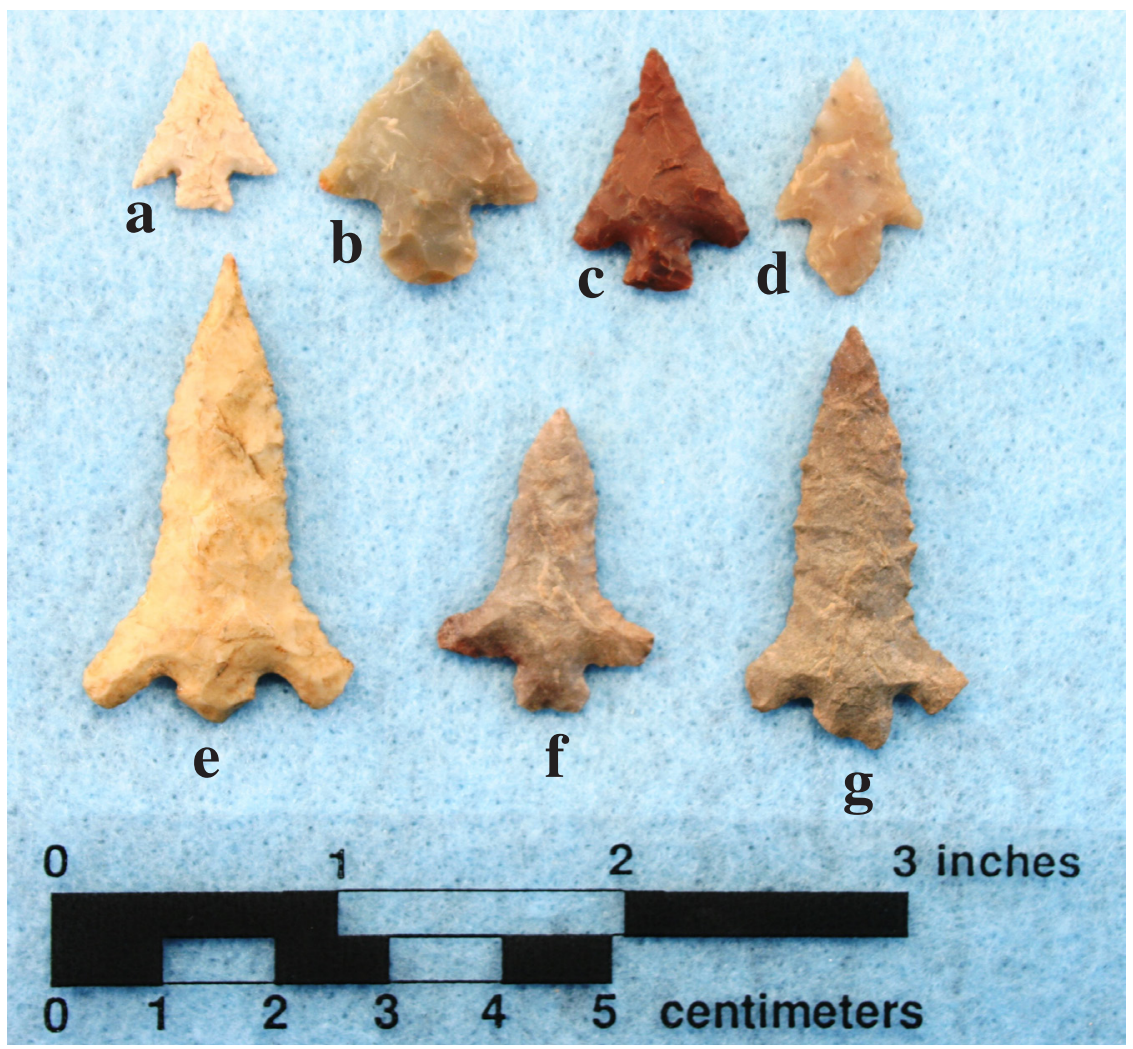

Figure 94. Stemmed arrow points in the George T. Wright collection from Red River County, Texas, GTW-994: a-c, f, Alba; d, Hayes; e, g, Catahoula.

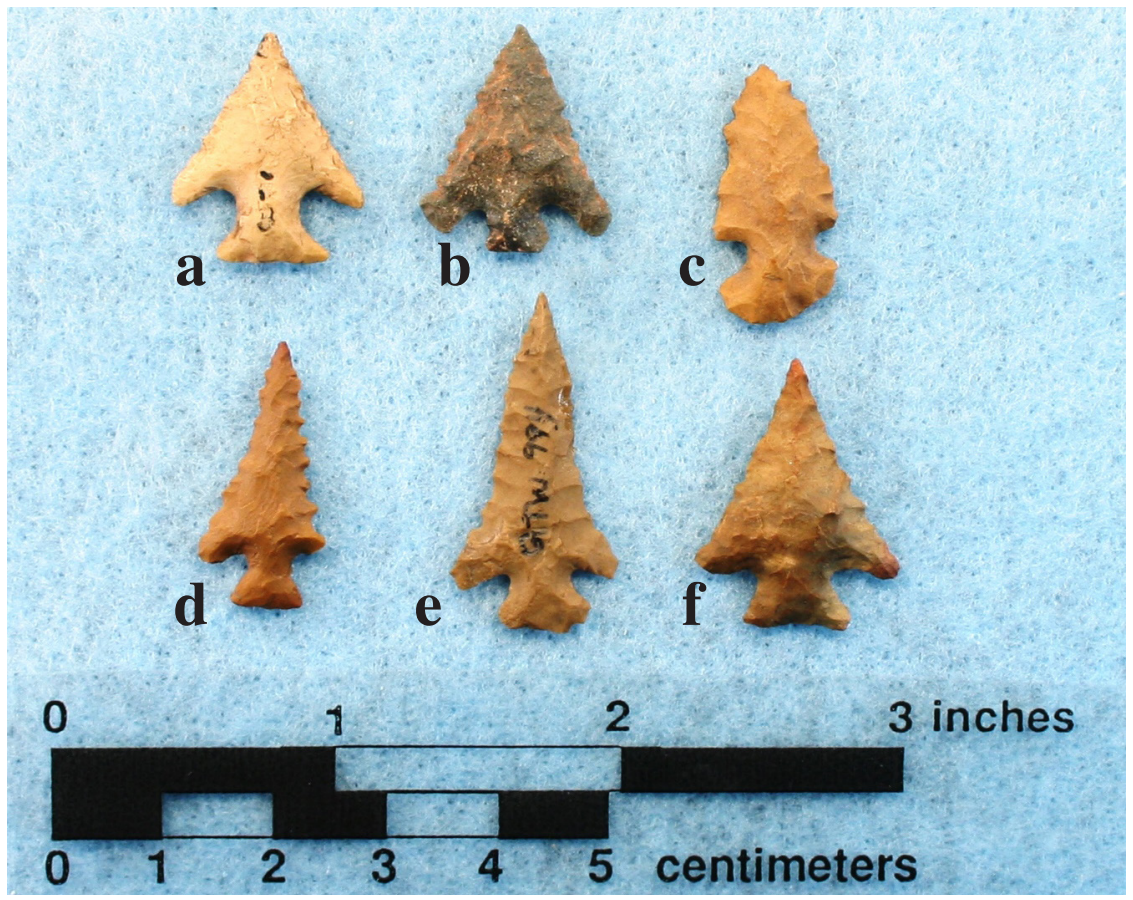

Figure 95. Stemmed arrow points in the George T. Wright collection from Red River County, Texas, GTW-994: c, Homan; a, d-f, Scallorn. 
Only one arrow point dates to the Middle Caddo period (ca. A.D. 1200-1400): the Hayes (see Figure 94d) form (see Turner et al. 2011:197). It is made from Red River novaculite.

Post-A.D. 1500 late McCurtain phase arrow points in the George T. Wright collection include Maud as well as Talco (Figure 96), Harrell (Figure 97), and Massard types (Figure 98). Massard arrow points (see Brown 1996:440 and Figures 2-57k-p and 2-60a-h, and 2-61b-d) have been found in a burial feature on the terrace area at the Sam Kaufman site in association with Maud and Talco points (Perttula 2008:Figure 55) as well as in a multiple burial and the shaft tomb in the East Mound at the site (Skinner et al. 1969:Figure 27e-f, j-m). These Late Caddo arrow point types are made primarily from Red River cherts (65.8 percent), especially a gray chert and a black Big Fork chert, along with jasper (23.7 percent), novaculite (5.3 percent), and quartzite (5.3 percent); the latter includes one Uvalde gravel point and another from Stanley/Jackfork formation quartzite (see Table 8).

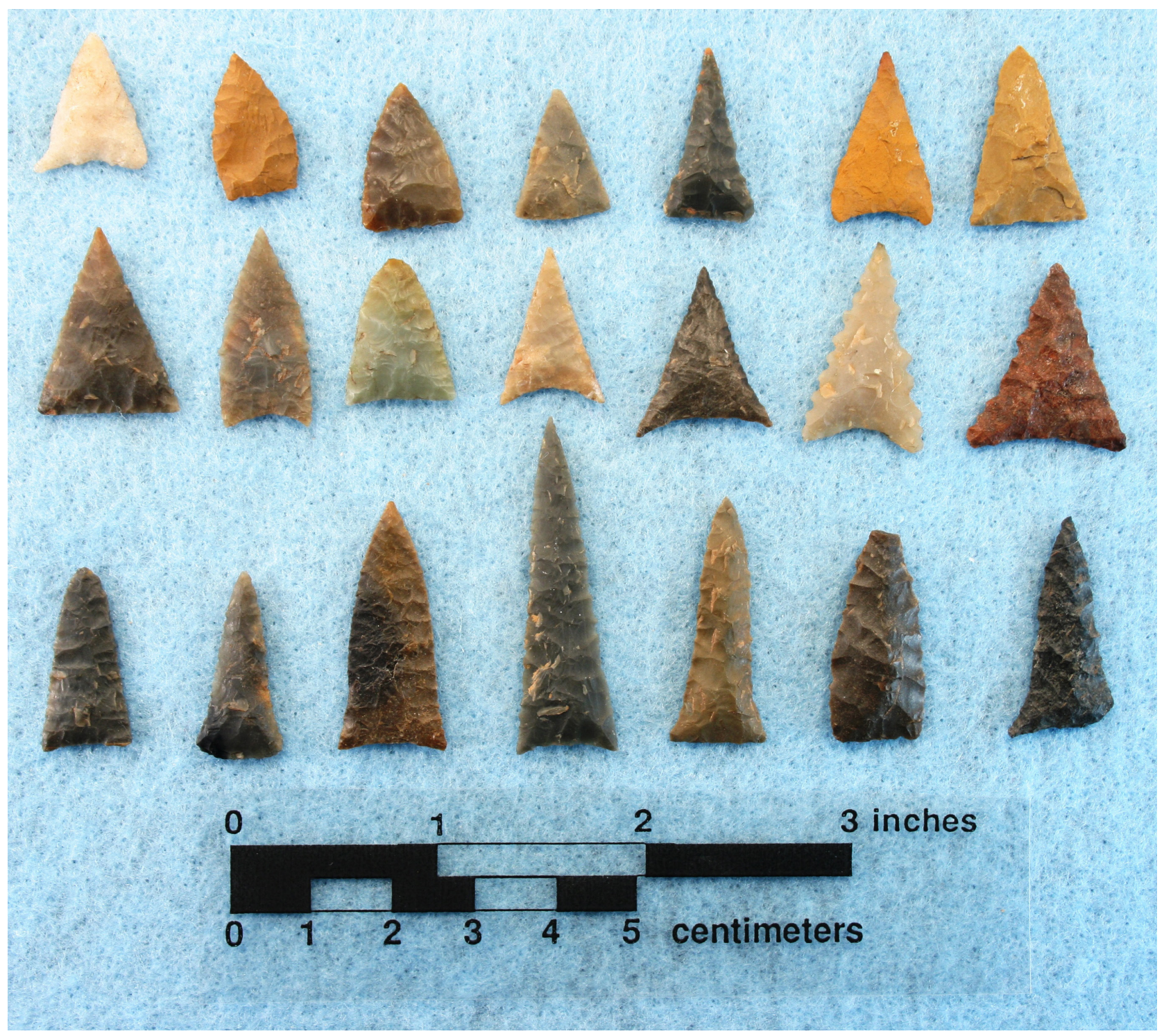

Figure 96. Triangular Maud and Talco arrow points, GTW-997. 


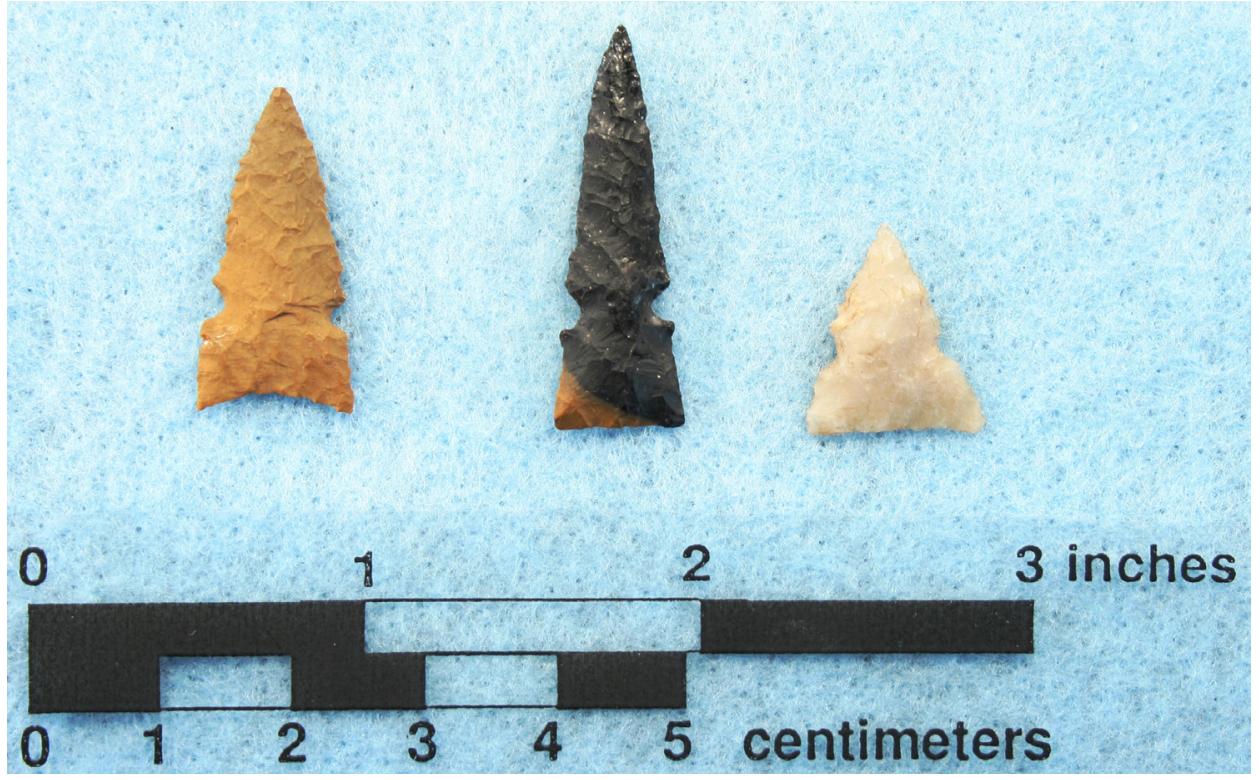

Figure 97. Harrell arrow points, GTW-997.

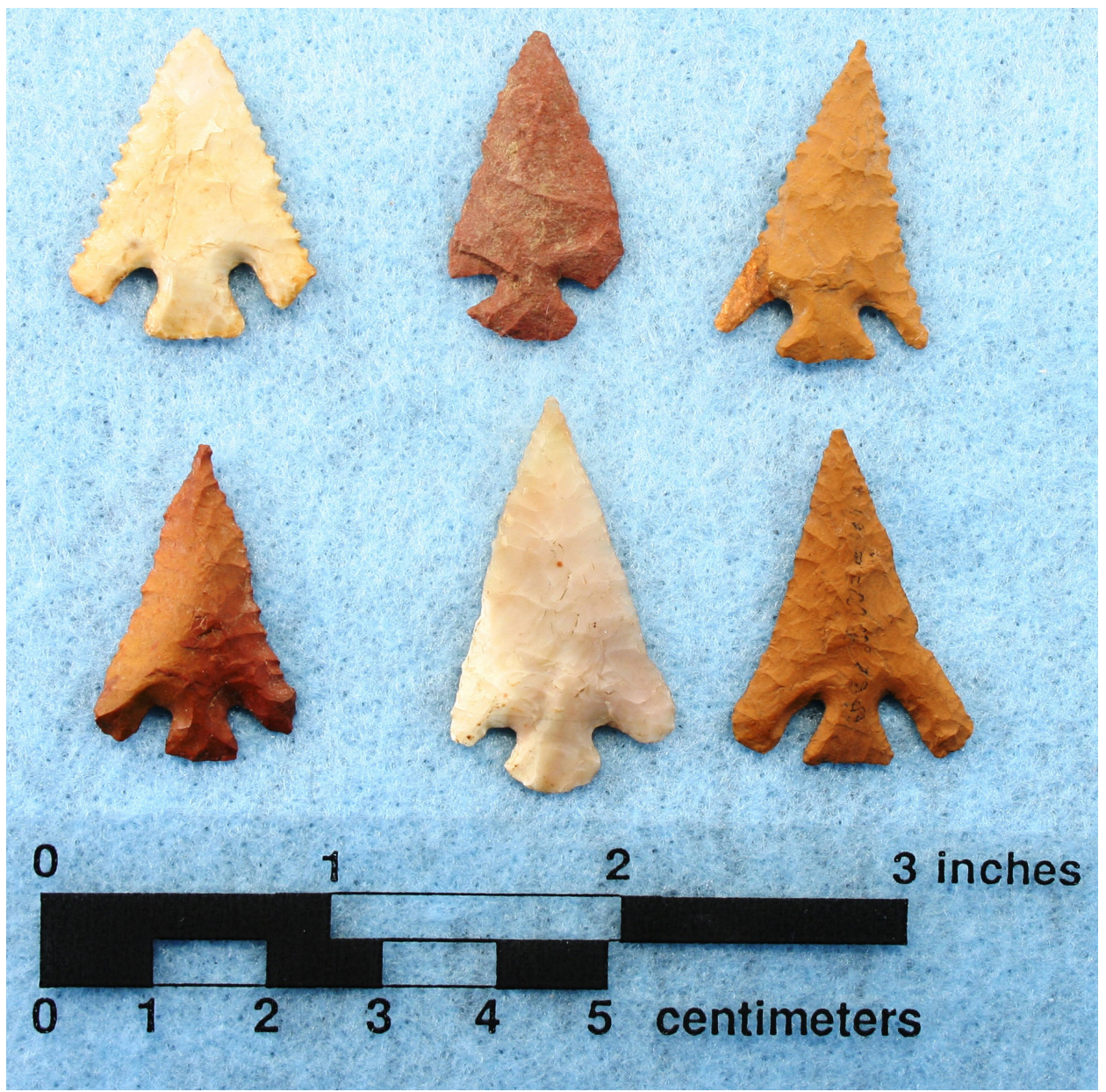

Figure 98. Massard arrow points, GTW-994. 


\section{Marine Shell}

The George T. Wright Collection has three poorly preserved marine conch columella beads (Figure 99) from a burial at the Sanders site (GTW-1006, TX 222/1, B. L.) (see Krieger 1946:Plate 19a-b). They range from $65.0-80.0 \mathrm{~mm}$ in length and $8.6-12.1 \mathrm{~mm}$ in width.

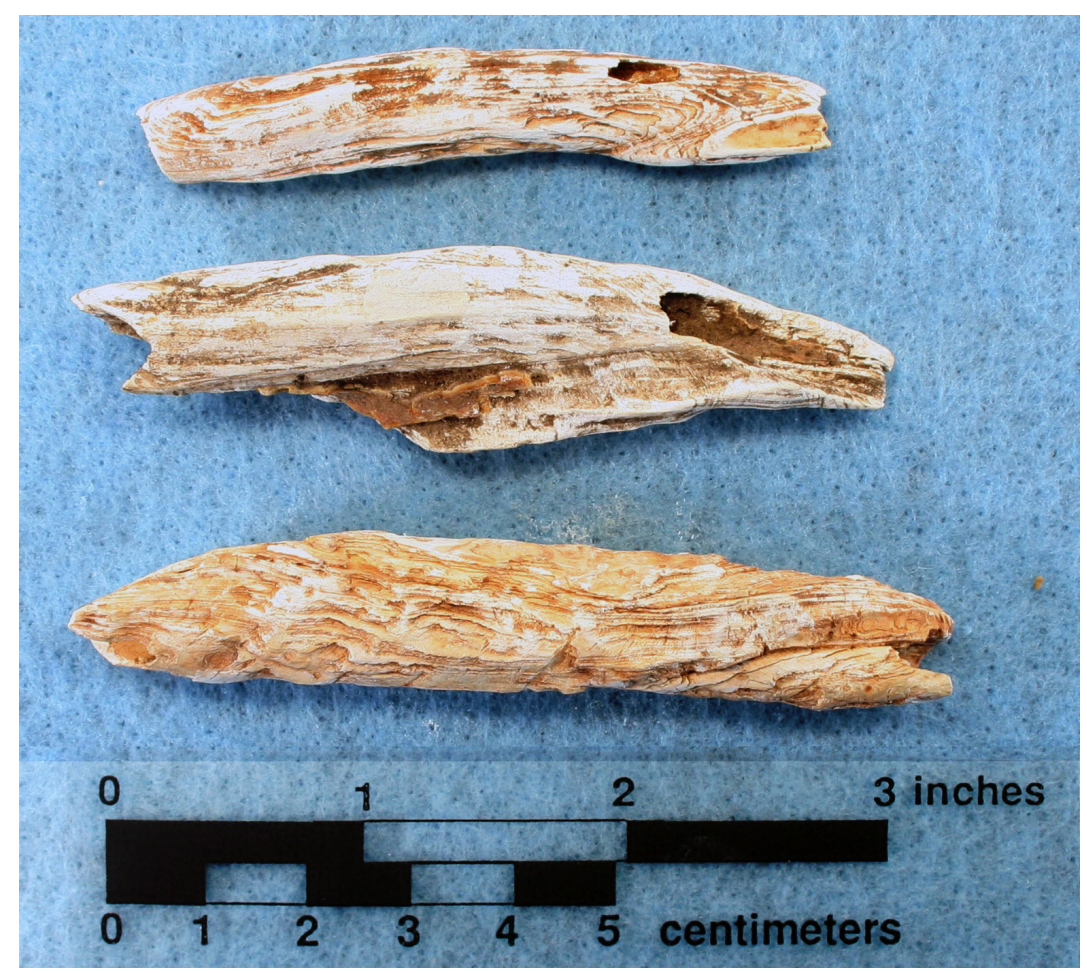

Figure 99. Marine shell columella beads from the Sanders site, GTW-1006.

\section{Bone Tools}

The George T. Wright collection of artifacts from Caddo sites in East Texas include two large animal bone tool fragments from the Sam Kaufman site (GTW-1018, TX 225/1, B. R. R.). These unburned large mammal bones have smoothed exterior surfaces (Figure 100a-b), as if they may have been used to polish animal hides. The two fragments range from 60-88.5 mm in length, 45.9-55.9 mm in width, and 29.0$31.3 \mathrm{~mm}$ in thickness.

Correspondence between A. T. Jackson and George T. Wright mentions these bone tools as coming from a burial feature at the Sam Kaufman site. Along with a pair of copper-covered wood ear spools with the burial, Wright noted:

...It may be of further interest to you to know what else was buried with this skeleton. Four pieces of pottery, none of any particular potter that would mark it odd or outstanding. This includes one small...flattish bottle with a bulbous neck. This was buried right between the legs in the crotch. Another bottle, by the way, was found in a similar location with another skeleton. At the waist, or hips, were two rather kidney shaped "nodules" of bone that had been much polished, as shown by the undisintegrated end of one, $31 / 4$ " x $21 / 4$ " x $11 / 2$ ". These were pretty soft and badly eroded. Evidently they cut out of a large animal bone-buffalo at a guess. 


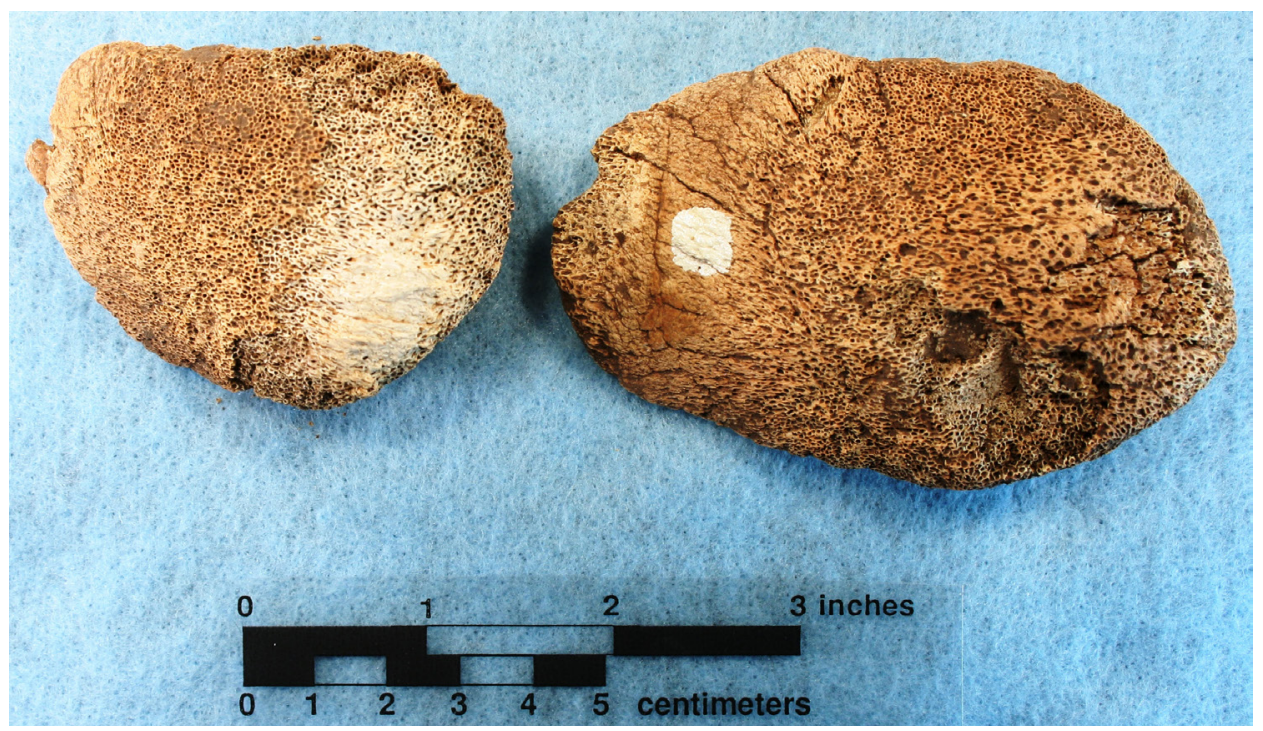

Figure 100. Bone tools from the Sam Kaufman site, GTW-1018.

These we took to be pot smoothers. Also with these, was a bone needle about 6" long, polished and smoothed. This would lead me to believe the skeleton was that of a woman. Another thing you will want to know -this grave was in the eastern or smaller mound (East Mound] on the Coffman farm [Figure 2] about 10 miles below my farm [at Wright Plantation] (Perttula 2017b).

\section{Glass Beads}

There are 18 glass beads (Figure 101) in the George T. Wright Collection from the Wright Plantation site in Red River County (GTW-1014, TX 223/1, B. R. R.). They can be sorted into two groups of large turquin (see Walthall 2015) or turquoise blue drawn or rounded beads. The first group includes 15 opaque beads between 5.9-7.3 mm in diameter; in the Kidd and Kidd (1970) system, they are IIa40/41 beads. The second group has three large translucent beads between 5.6-5.9 $\mathrm{mm}$ in diameter; these are IIa31 beads in the Kidd and Kidd 91970) system. Such beads are present on Caddo sites dating from ca. A.D. 1690-1730 (Perttula and Glascock 2017:Table 22.7).

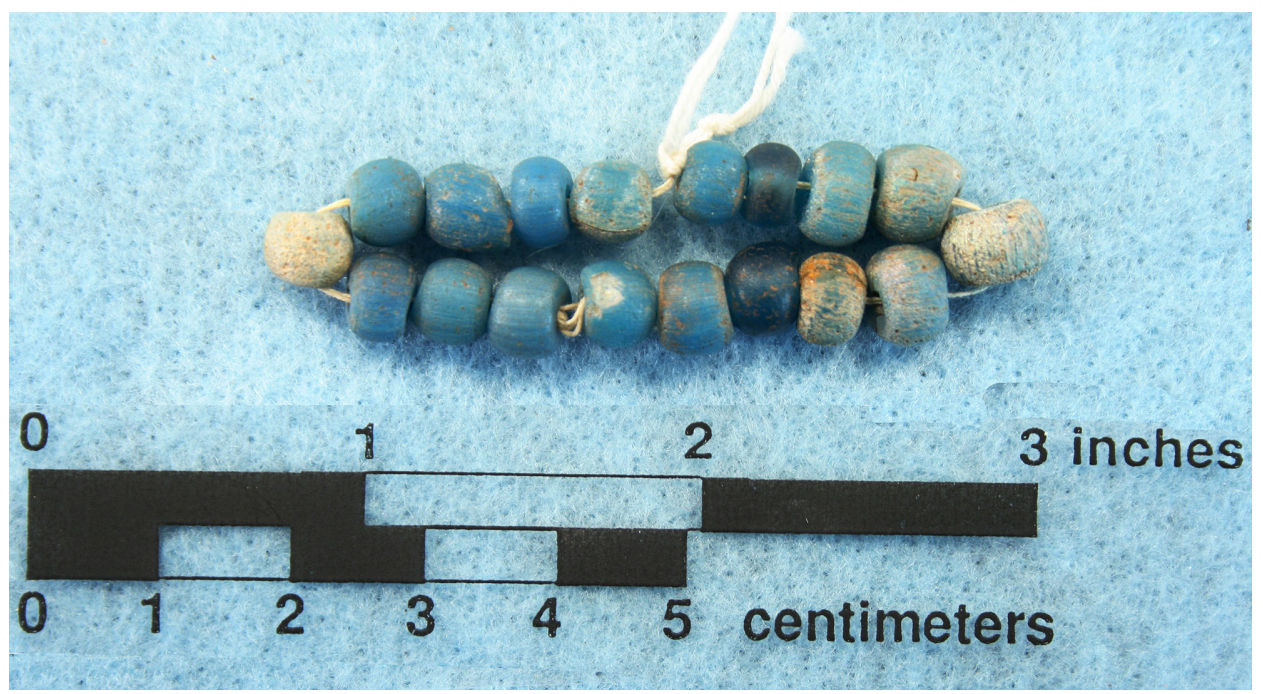

Figure 101. Glass beads from the Wright Plantation site, GTW-1014. 


\section{Summary and Conclusions}

This publication presents our documentation and analysis of a variety of ancestral Caddo material culture remains from sites in Red River, Lamar, and Titus counties in East Texas that were excavated and/ or collected by George T. Wright between ca. 1900-1940, and then donated or sold to the University of Oklahoma in the mid-1940s. Most of the material culture remains are from burial contexts, or else collected from the surface of those same sites, particularly from burial features at the Wright Plantation (41RR7) and Sam Kaufman (41RR16) sites.

This collection is held by the Sam Noble Oklahoma Museum of Natural History (SNOMNH) at the University of Oklahoma, and includes ceramic vessels, ceramic pipes, arrow points, marine shell beads, animal bone tools, and European glass trade beads. The legal requirements of the Native American Graves Protection and Repatriation Act (NAGPRA) are applicable because of the funerary context of most of the artifacts in the George T. Wright collection, and this collection has been determined to be culturally affiliated with the Caddo Nation of Oklahoma. Consequently, we requested, and then received, a letter of support from the Caddo Nation to the SMOMNH providing us with access to these NAGPRA collections for documentation and research purposes.

The George T. Wright Collection from East Texas sites consists of 85 ceramic vessels, all but one of ancestral Caddo manufacture. The other vessel is from a site in southern Lamar County, in the Sulphur River basin, one of $19^{\text {th }}$ century age that was made by a Southwestern Native American group living in the northern Rio Grande basin in northern New Mexico. It is likely that this ceramic vessel is a result of the flourishing exchange of products across the Southern Plains and beyond created by the Comanche horse trade of that time (see Hamalainen 2008:151). Nineteenth century Southwestern ceramics from the northern Rio Grande region of New Mexico have also been identified at the Longest site (34JF1) on the Red River, an important fortified Wichita site (Baugh and Blaine 2017:Figure 6c). The Wichita also had an abundance of horses for trade that they had acquired by raiding and trading, and they were also trading with the Chickasaw: English trade goods for horses, prepared bison hides, and captives (Baugh and Blaine 2017:112-113).

Also in the collection are a number of elbow ceramic pipes and long-stemmed Red River pipe sherds, arrow points, marine shell beads, bone tools, and a small strand of blue glass beads. These artifacts from sites in Red River, Lamar, and Titus counties testify to the ancestral Caddo use of these areas from as early as ca. A.D. 700 in the late Woodland period to the early $18^{\text {th }}$ century at the Wright Plantation site and the Sam Kaufman site. While Wright excavated a few Caddo burial features of Early (ca. A.D. 10001200) and Middle Caddo (ca. A.D. 1200-1400) period age from sites in Red River and Lamar counties, by far the best represented period of Caddo settlement and cemetery use in the Red River basin in George T. Wright's collection is during the Late Caddo period McCurtain phase, from ca. A.D. 1400-1680.

Like other Caddo groups on the Red River, the McCurtain phase settlement pattern in the middle Red River basin included numerous habitation sites (with household cemeteries and substantial midden deposits) and mound centers, although the mounds appear to have mainly been constructed in the early part of the phase (ca. A.D. 1400-1550); the McCurtain phase is not well-dated through radiocarbon analysis, however. Radiocarbon dates from McCurtain phase contexts at the Sam Kaufman, Holdeman (41RR11), and Rowland Clark (41RR77) sites indicate that the McCurtain phase can be divided into early (ca. A.D. 1400-1550) and late (ca. A.D. 1550-1680) contexts, with corresponding changes in ceramic decorative styles and arrow point shapes. The early McCurtain phase residential and mortuary features at the Holdeman site date to cal. A.D. 1392-1478 and cal. A.D. 1332-1513 at Roitsch-Sam Kaufman, while 2 sigma calibrated dates from later burial features with slightly different ceramic assemblages at the Rowland Clark site range at 2 sigma from cal. A.D. 1447-1697. 
In some instances, mound centers were not directly associated with permanent settlements or middens. The McCurtain phase mounds were generally constructed in one or two stages over important public structures, with the structure abandoned, dismantled and/or burned, then capped with a rituallycharged zone of soil scraped from nearby deposits or clay sources. Simple and elaborate single and multiple burials were also placed in the mounds, as with the East Mound at the Sam Kaufman site (41RR16) on the Red River.

The density of McCurtain phase sites indicates that greater numbers of Caddo people were living in closer proximity than before in the Red River valley. At the Sam Kaufman site, the mound in McCurtain phase times was used as a place for the burial of the social elite, as a shaft tomb with 11 individuals and many grave goods was located near the center of the mound. Special purpose salt-processing sites, such as the Salt Well Slough site (41RR204), are also common in the vicinity of the Sam Kaufman site.

Late Caddo period vessel assemblages are stylistically diverse across East Texas, and there are very specific differences in vessel shapes, designs, and decorative attributes between Caddo ceramics in individual drainages, or even within specific smaller segments of river and creek basins. The stylistic and functional diversity in Late Caddo Titus phase, Frankston phase, and McCurtain phase (see Figure 87) fine ware and utility ware ceramics, for example, can be reasonably interpreted to be representative of the ceramic traditions of specific Caddo social groups.

McCurtain phase ceramics are exclusively shell-tempered, with the exception of certain grogtempered vessels apparently obtained from contemporaneous Texarkana phase Caddo communities living downstream along the Red River. Fine ware vessels in McCurtain phase sites include Avery Engraved, Hudson Engraved, Keno Trailed, and Simms Engraved bottles, bowls, and carinated bowls, along with a plain red-slipped fine ware (Clement Redware). Simms Engraved, var. Darco is a post-A.D. 1650 fine ware style present in late McCurtain phase contexts as well as in the early part of the Historic Caddo period, and this variety is quite common in the George T. Wright collection. The utility ware jars are from Nash Neck Banded and Emory Punctated-Incised types. Clay elbow pipes were made, used, and discarded in the different village areas and farmstead compounds as well as placed in graves as funerary offerings, along with likely quivers of arrow points and other goods.

\section{References Cited}

Banks, L. D.

1990 From Mountain Peaks to Alligator Stomachs: A Review of Lithic Sources in the Trans-Mississippi South, the Southern Plains, and Adjacent Southwest. Memoir \#4. Oklahoma Anthropological Society, Norman.

Banks, L. D. and N. T. Banks

2002 Last Twentieth Century Archeological Investigations at the Arnold Roitsch Site (41RR16), Red River County, Texas. Larry D. Banks, Detroit, Texas.

Banks, L. D. and J. Winters

1975 The Bentsen-Clark Site, Red River County, Texas: A Preliminary Report. Special Publication No. 2. Texas Archeological Society, San Antonio.

Baugh, T. G. and J. C. Blaine

2017 Enduring the violence: Four centuries of Kirikir'i-s warfare. Plains Anthropologist 62 (242):99132. 
Brown, J. A.

1996 The Spiro Ceremonial Center: The Archaeology of Arkansas Valley Caddoan Culture in Eastern Oklahoma. 2 Vols. Memoirs No. 29. Museum of Anthropology, The University of Michigan, Ann Arbor.

Cobb, $\mathrm{H}$.

1983 A Burial at the Sam Kaufman Site. The Record 39(1):3-7, 9. Dallas Archeological Society, Dallas.

Dowd, E. L.

2011 Identifying Variation: A Stylistic Analysis of Four Caddo Pottery Assemblages from Southeastern Oklahoma. Memoir 15. Oklahoma Anthropological Society, Norman.

Ferring, C. R. and T. K. Perttula

1987 Defining the Provenance of Red-Slipped Pottery from Texas and Oklahoma by Petrographic Methods. Journal of Archaeological Science 14:437-456.

Fields, R. C., V. L. Hatfield, D. Burden, E. F. Gadus, M. C. Wilder, and K. W. Kibler

2014 Testing and Data Recovery Excavations at 11 Native American Archeological Sites along the U.S. Highway 271 Mount Pleasant Relief Route, Titus County, Texas. 2 Vols. Reports of Investigations No. 168. Prewitt and Associates, Inc., Austin.

Hamalainen, P.

2008 The Comanche Empire. Yale University Press, New Haven.

Harris, R. K.

1953 The Sam Kaufman Site, Red River County, Texas. Bulletin of the Texas Archeological Society 24:43-68.

Harris, R. K. and L. Wilson

1956 Burial 17, The Sam Kaufman Site (19B3-2). The Record 14(4):17-22. Dallas Archeological Society, Dallas.

Harris, R. K., Mr. J. Perkins, and Mrs. J. Perkins

1954 Burials 12,13, 14, and 15, The Sam Kaufman Site 19B32. The Record 13(1):2-8. Dallas Archeological Society, Dallas.

Hoffman, M. P.

1967 Ceramic Pipe Style Chronology Along the Red River Drainage In Southwestern Arkansas. The Arkansas Archeologist 8(1):4-14.

Huff, M. E., Jr.

1960 Burial 18, The Sam Kaufman Site. The Record 15(1):24. Dallas Archeological Society, Dallas.

Jackson, A. T., M. S. Goldstein, and A. D. Krieger

2000 The 1931 Excavations at the Sanders Site, Lamar County, Texas: Notes on the Fieldwork, Human Osteology, and Ceramics. Archival Series 2. Texas Archeological Research Laboratory, The University of Texas at Austin. 
Jones, B. C.

1968 The Kinsloe Focus: A Study of Seven Historic Caddoan Sites in Northeast Texas. Master's thesis, Department of Anthropology, University of Oklahoma, Norman.

Kidd, K. E. and M. A. Kidd

1970 A Classification System for Glass Beads for the Use of Field Archaeologists. Canadian Historic Sites, Occasional Papers in Archaeology and History 1. Ottawa, Canada.

Krieger, A. D.

1946 Culture Complexes and Chronology in Northern Texas, with Extensions of Puebloan Datings to the Mississippi Valley. Publication No. 4640. The University of Texas, Austin.

Nash, L.

2017 The Cosmos in Clay: An Analysis of Avery Engraved Vessel Motifs. Master's Thesis, Cornell University, Ithaca, New York.

Perino, G.

1983 Archaeological Research at the Bob Williams Site, Red River County, Texas. Potsherd Press, Museum of the Red River, Idabel, Oklahoma.

1994 Archaeological Research at the Rowland Clark Site (41RR77), Red River County, Texas. Journal of Northeast Texas Archaeology 4:3-42.

1995 The Dan Holdeman Site (41RR11), Red River County, Texas. Journal of Northeast Texas Archaeology 6:3-65.

Perttula, T. K.

1995 A Reconsideration of the Chronological and Cultural Placement of the Mortuary Remains and Grave Goods from the Dan Holdeman Site. Journal of Northeast Texas Archaeology 6:67-87.

2008 The Archeology of the Roitsch Site (41RR16), an Early to Historic Caddo Period Village on the Red River in Northeast Texas. In Collected Papers from Past East Texas Archeological Society Summer Field Schools, edited by T. K. Perttula, pp. 313-628. Special Publication No. 5. Texas Archeological Society, San Antonio.

2012 The Character of Fifteenth- to Seventeenth-Century Caddo Communities in the Big Cypress Creek Basin of Northeast Texas. In The Archaeology of the Caddo, edited by T. K. Perttula and C. P. Walker, pp. 363-410. University of Nebraska Press, Lincoln.

2015a East Texas Caddo Ceramic Sherd Database. Journal of Northeast Texas Archaeology 51:1-46.

2015b Caddo Ceramic Vessels from the Hatchel Site (41BW3) on the Red River in Bowie County, Texas. Special Publication No. 39. Friends of Northeast Texas Archaeology, Austin and Pittsburg.

2016a Ancestral Caddo Ceramic Vessels from the Wright Plantation (41RR7) and Rowland Clark (41RR77) Sites in the Harris Collection at the National Museum of Natural History, Smithsonian Institution. Journal of Northeast Texas Archaeology 70:115-119.

2016b Caddo Ceramic Vessels from the Sam Kaufman Site (41RR16) in the R. K. Harris Collection at the National Museum of Natural History, Smithsonian Institution. Journal of Northeast Texas Archaeology 70:121-127. 
2017a Documentation of Ancestral Caddo Ceramic Vessels from Sites in Red River County, Texas. Journal of Northeast Texas Archaeology 75:1-13.

2017b Correspondence between George T. Wright and A. T. Jackson Regarding Late 1930s-Early 1940s Excavations at the Sam Kaufman Site (41RR16). Journal of Northeast Texas Archaeology 75:83-93.

Perttula, T. K. (editor)

2005 Archeological Investigations at the Pilgrim's Pride Site (41CP304), a Titus Phase Community in the Big Cypress Creek Basin, Camp County, Texas. 2 Vols. Report of Investigations No. 30. Archeological \& Environmental Consultants, LLC, Austin.

Perttula, T. K. and M. D. Glascock

2017 Glass Beads. In La Belle: The Archaeology of a Seventeenth-Century Ship of New World Colonization, edited by J. E. Bruseth, A. A. Borgens, B. M. Jones, and E. D. Ray, pp. 509-530. Texas A\&M University Press, College Station.

Perttula, T. K. and R. Z. Selden Jr.

2014 Ancestral Caddo Ceramics in East Texas. Journal of Northeast Texas Archaeology 48:9-58.

Perttula, T. K., P. S. Marceaux, B. Nelson, and M. Walters

2015 Caddo Ceramic Vessels from Sites in the Upper Neches River Basin of East Texas, Anderson and Cherokee Counties, Texas. Special Publication No. 37. Friends of Northeast Texas Archaeology, Austin and Pittsburg.

Perttula, T. K., B. Nelson, and R. Z. Selden Jr.

2013 Documentation of Cemeteries and Funerary Offerings from Sites in the Upper Neches River Basin, Anderson, Cherokee, and Smith Counties, Texas. Special Publication No. 26. Friends of Northeast Texas Archaeology, Pittsburg and Austin.

Perttula, T. K., M. Walters, and B. Nelson

2012 Early 1960s Excavations at the Sam Kaufman Site (41RR16), Red River County, Texas. Journal of Northeast Texas Archaeology 36:1-31.

2016 Caddo Ceramic Vessels from the T. M. Sanders Site (41LR2) on the Red River in Lamar County, Texas. Special Publication No. 41. Friends of Northeast Texas Archaeology, Austin and Pittsburg.

Prikryl, D. J.

2008 The 1991 and 1992 Texas Archeological Society Field School Excavations at the Fasken Site (41RR14), Red River County, Texas. In Collected Papers from Past Texas Archeological Society Summer Field Schools, edited by T. K. Perttula, pp. 125-171. Special Publication No. 5. Texas Archeological Society, San Antonio.

Rice, P. M.

1987 Pottery Analysis: A Sourcebook. University of Chicago Press, Chicago.

Schambach, F. F. and J. E. Miller

1984 A Description and Analysis of the Ceramics. In Cedar Grove: An Interdisciplinary Investigation of a Late Caddo Farmstead in the Red River Valley, edited by N. L. Trubowitz, pp. 109-170.

Research Series No. 23. Arkansas Archeological Survey, Fayetteville.

Shafer, H. and M. Walters 
2010 The Browning Site (41SM195A) Lithics: Considering Patterns of Identity and Interaction Through Lithic Analysis. Bulletin of the Texas Archeological Society 81:127-151.

Skinner, S. A., R. K. Harris, and K. M. Anderson (editors)

1969 Archaeological Investigations at the Sam Kaufman Site, Red River County, Texas. Contributions in Anthropology No. 5. Department of Anthropology, Southern Methodist University, Dallas.

Suhm, D. A. and E. B. Jelks (editor)

1962 Handbook of Texas Archeology: Type Descriptions. Special Publication No. 1, Texas Archeological Society, and Bulletin No. 4, Texas Memorial Museum, Austin.

Teltser, P. A.

1993 An Analytic Strategy for Studying Assemblage-Scale Ceramic Variation: A Case Study from Southeast Missouri. American Antiquity 58(3):530-543.

Todd, J. and R. L. Turner

2010 Clay Pipes from the Tuck Carpenter Site (41CP5), Camp County, Texas. Caddo Archeology Journal 20:143-146.

Turner, E. S., T. R. Hester, and R. L. McReynolds

2011 Stone Artifacts of Texas Indians. $3^{\text {rd }}$ Edition. Taylor Trade Publishing, Lanham, Maryland.

Turner, R. L., Jr.

1978 The Tuck Carpenter Site and Its Relation to Other Sites Within the Titus Focus. Bulletin of the Texas Archeological Society 49:1-110.

Walthall, J. A.

2015 Seventeenth-Century Glass Trade Beads from La Salle's Fort St. Louis and the Grand Village of the Kaskaskia. Midcontinental Journal of Archaeology 40(3):257-281.

Wright, G. T.

1943 A Pueblo Pot Found Near Paris, Texas. Bulletin of the Texas Archeological and Paleontological Society 15:92-96. 



\section{Appendix I}

\section{Observations on the Pueblo Ceramic Vessel found in Lamar County, Texas}

\section{Matthew C. Pailes}

Aplastic: inclusions are reddish in color, some several $\mathrm{mm}$ in size. Grains are sub-angular, and seem to be argillaceous/pelitic, and are likely crushed ceramic pieces (Figure A1-1). There are no fresh breaks on this vessel; in old breaks, aplastic grains appear to have oxidation rinds with black interiors, and grains in the interior of the paste seem to be all black. A few white inclusions are likely natural or secondary minerals.

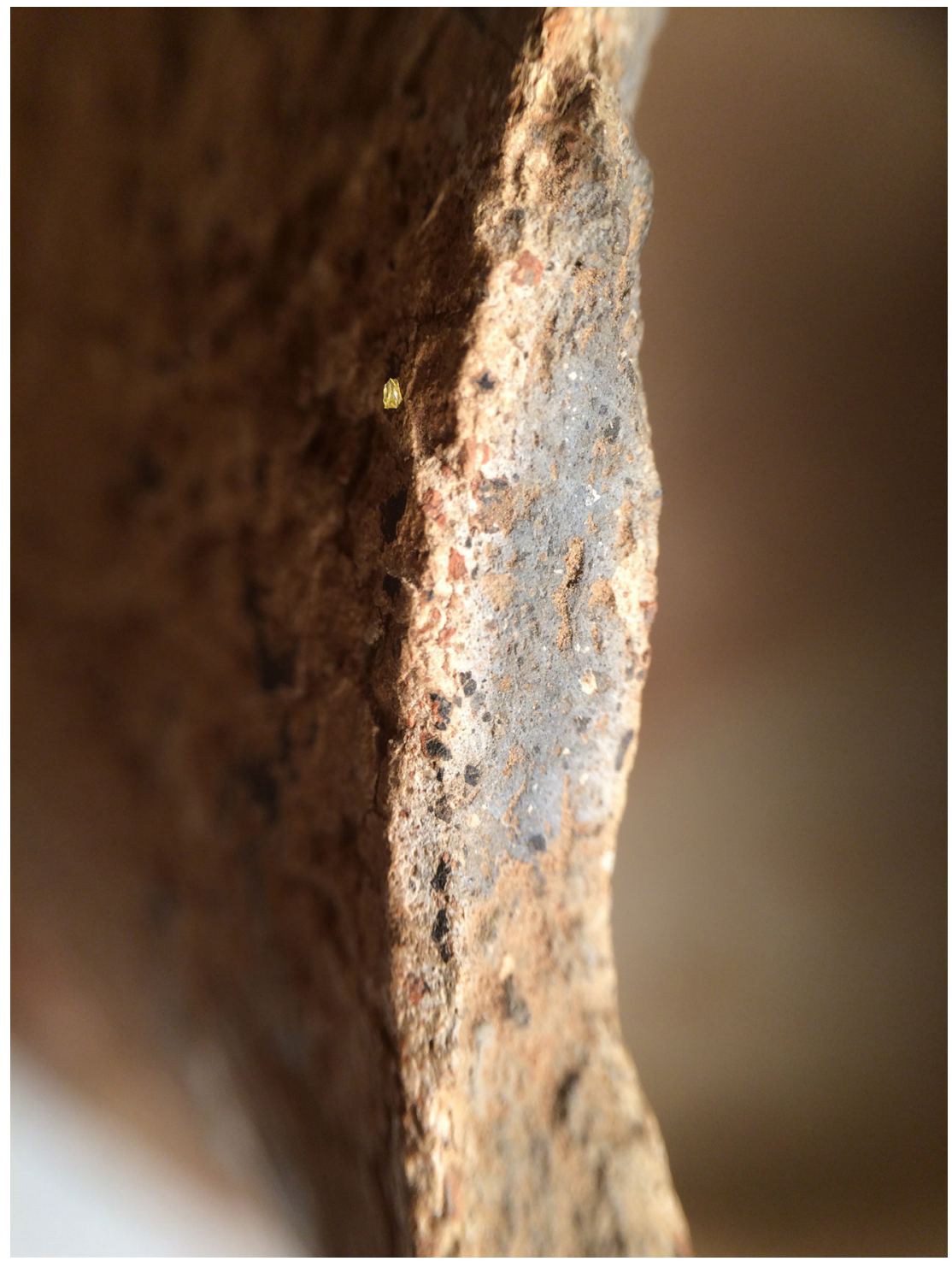

Figure A1-1. Cross-section of Lamar County vessel, showing aplastics in the paste. 
Paste: durable and relatively fine; the interior color is light gray varying to darker gray in the center of the cross-section (Figure A1-2), with no sharp breaks in the color. The outside of the vessel is fired to a buff/tan color. Scraping/wipe marks are easily observable on the interior of the vessel.

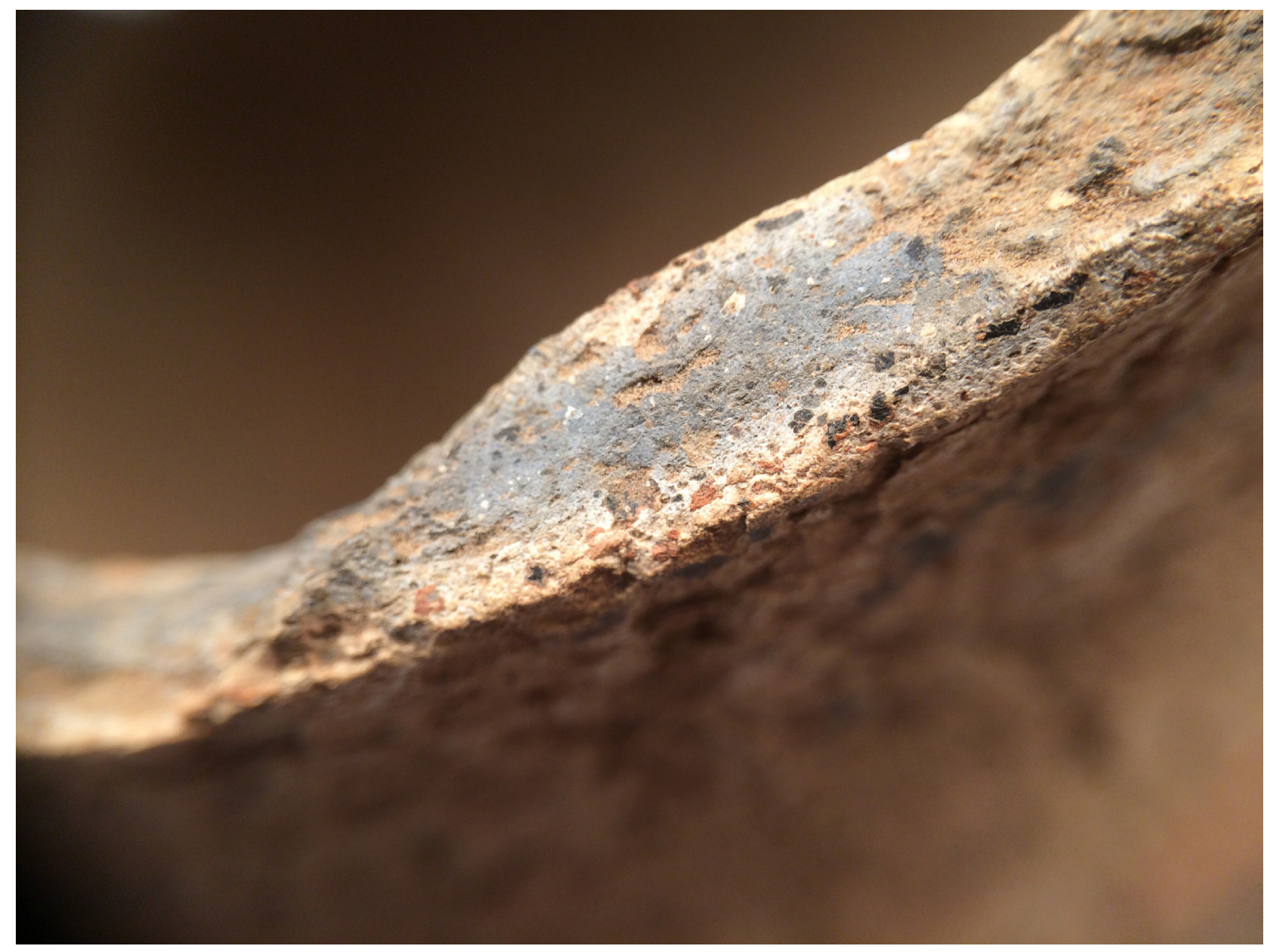

Figure A1-2. Close-up of the cross-section of the paste in the Lamar County vessel.

There are large spalls on the lower portion of the vessel, likely post burial-exfoliation.

Paint: slip is a white color that appears polished-lustrous. The red paint is matte (Figure A1-3); clear brush strokes are inferrable from uneven color: the elements are outlined and then in-filled. Some granularity visible in the red paint under magnification with hand-lens. The boundaries of the red paint are relatively sharp. The dark paint is a root-beer color. The edges are sharp with no evidence of running. There is some gradation in the color with a darker interior of strokes and lighter margins. A few locations suggest bubbling in the paint, most likely this is a glaze or sub-glaze paint. 


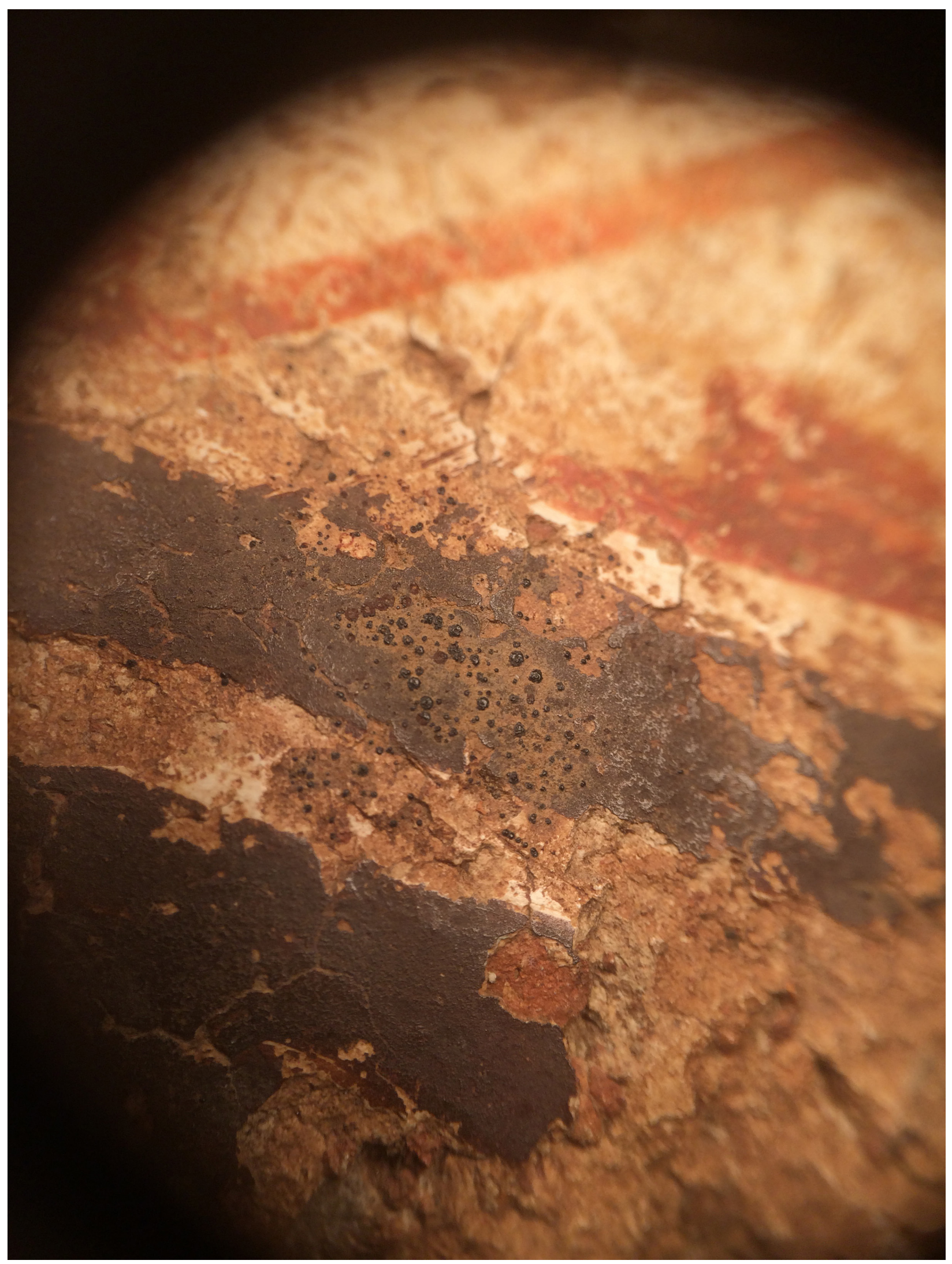

Figure A1-3. Close-up of white and red paints on the Lamar County vessel. 
